B O N N E V I L L E P O W E R A D M I N I S T R A T I O Evaluation of Juvenile Salmonid Outmigration and Survival in the Lower Umatilla River Basin

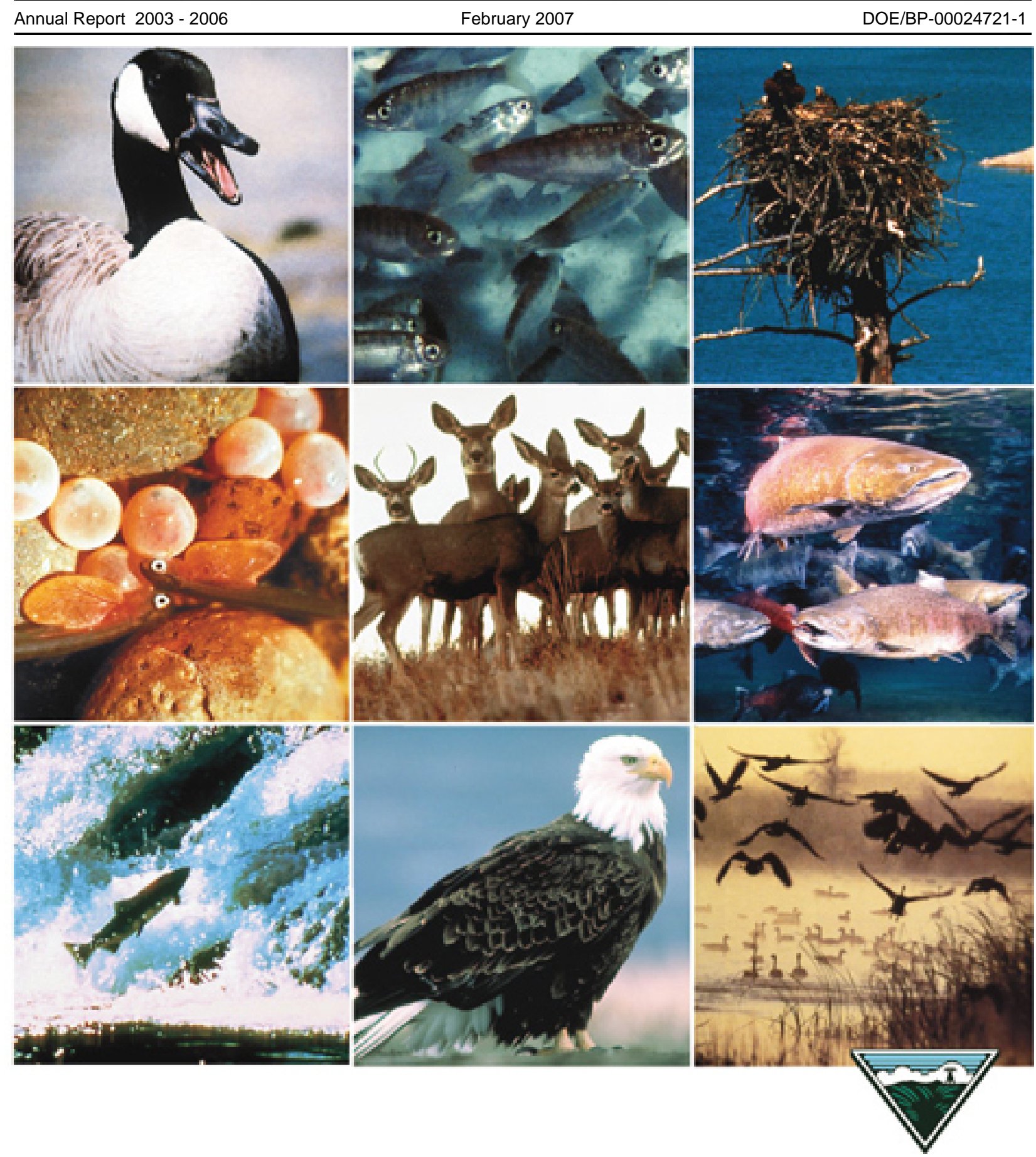


This Document should be cited as follows:

White, Tara, Josh Hanson, Shannon Jewett, Richard Carmichael, "Evaluation of Juvenile Salmonid Outmigration and Survival in the Lower Umatilla River Basin", 2003-2006 Annual Report, Project No. 198902401, 131 electronic pages, (BPA Report DOE/BP-00024721-1)

\author{
Bonneville Power Administration \\ P.O. Box 3621 \\ Portland, OR 97208
}

This report was funded by the Bonneville Power Administration (BPA), U.S. Department of Energy, as part of BPA's program to protect, mitigate, and enhance fish and wildlife affected by the development and operation of hydroelectric facilities on the Columbia River and its tributaries. The views in this report are the author's and do not necessarily represent the views of BPA. 


\title{
EVALUATION OF JUVENILE SALMONID OUTMIGRATION AND SURVIVAL IN THE LOWER UMATILLA RIVER BASIN
}

\author{
ANNUAL REPORT 2004-2006 \\ (1 OCTOBER 2003 - 30 SEPTEMBER 2006)
}

\author{
Prepared by: \\ Tara C. White \\ Josh T. Hanson \\ Shannon M. Jewett \\ Richard W. Carmichael
Oregon Department of Fish and Wildlife
3406 N.E. Cherry Avenue
Salem, OR 97303-4924

\section{Prepared for:}

\author{
U.S. Department of Energy \\ Bonneville Power Administration \\ Environment, Fish and Wildlife \\ P.O. Box 3621 \\ Portland, OR 97208-3621
}

Project Number 1989-024-01

Contract Number 24721

February 2007 
This report was funded by the Bonneville Power Administration (BPA), U.S. Department of Energy, as part of BPA's program to protect, mitigate, and enhance fish and wildlife affected by the development and operation of hydroelectric facilities on the Columbia River and its tributaries. The views of this report are the author's and do not necessarily represent the views of BPA.

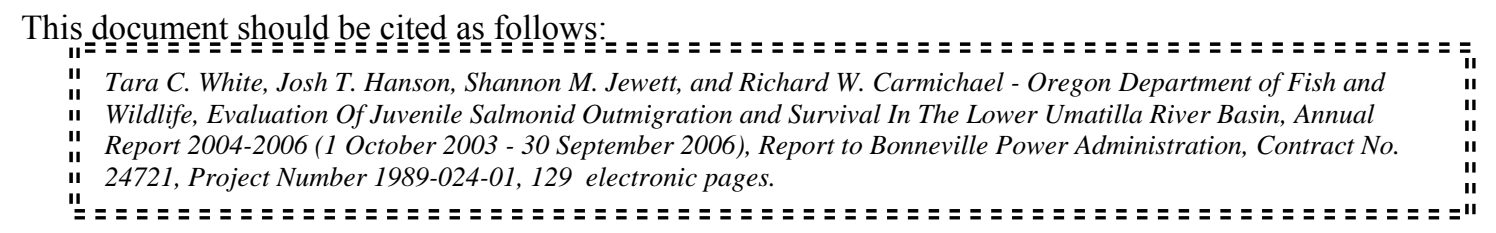

This report and other BPA Fish and Wildlife Publications are available on the Internet at:

\section{http://www.efw.bpa.gov/cgi-bin/efw/FW/publications.cgi}

For other information on electronic documents or other printed media, contact or write to:

Bonneville Power Administration

Environment, Fish and Wildlife Division

P.O. Box 3621

905 N.E. 11 th Avenue

Portland, OR 97208-3621

Please include title, author, and DOE/BP number in the request. 


\section{ACKNOWLEDGEMENTS}

The success of Umatilla Juvenile Outmigration and Survival M\&E Project is the result of efforts by many individuals within the Oregon Department of Fish and Wildlife and from other agencies.

We would like to thank Mr. Matt Powell for many hours of trap operation and field data collection in 2004. Special recognition is also extended to staff from the Pacific States Marine Fisheries Commission's Kennewick field office for their generous assistance in upgrade of the PIT Tag interrogation system at Three Mile Falls Dam.

The invaluable assistance of numerous field personnel, administrators, and agencies including individuals from the Bureau of Reclamation, the Confederated Tribes of the Umatilla Indian Reservation, West Extension Irrigation District personnel, the fish passage facility's Operation and Maintenance staff, ODFW Pathology staff in La Grande, Irrigon and Umatilla Hatchery personnel, the staff of the Umatilla Hatchery Monitoring and Evaluation project, and staff of the Umatilla Hatchery Satellite Facilities Operation and Maintenance project is greatly appreciated.

Special thanks is also extended to Mr. Jonathan McCloud of the Bonneville Power Administration for his endless project support.

This work was funded through Bonneville Power Administration's Fish and Wildlife Program. 


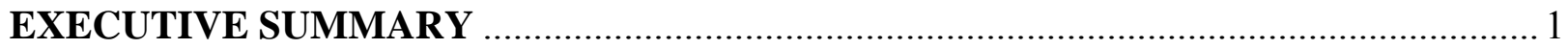

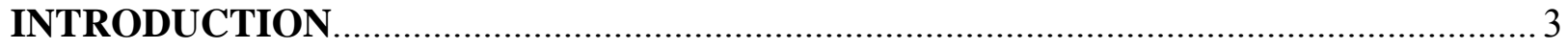

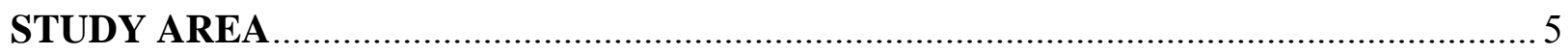

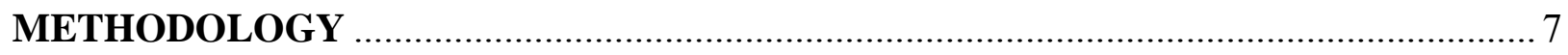

Outmigration Monitoring .................................................................................... 7

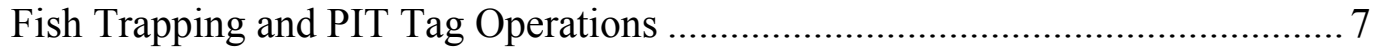

Fish Condition and Life History Characteristics ........................................ 7

Migration Parameters ........................................................................... 8

Abundance and Survival ............................................................................... 9

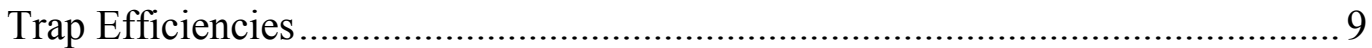

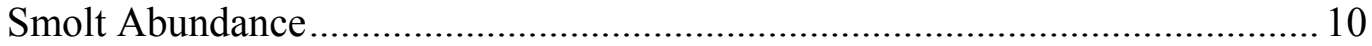

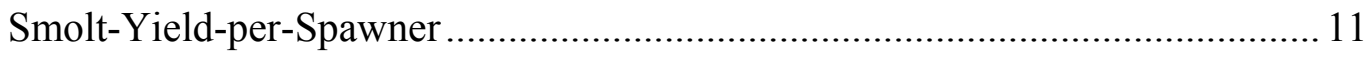

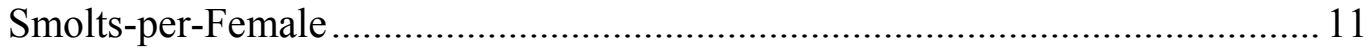

Smolt Survival ................................................................................. 11

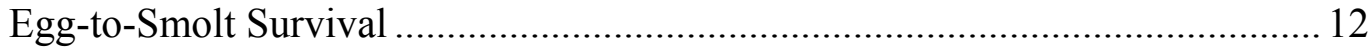

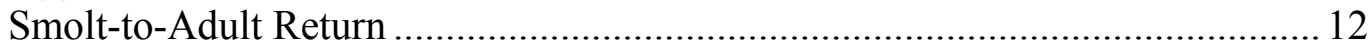

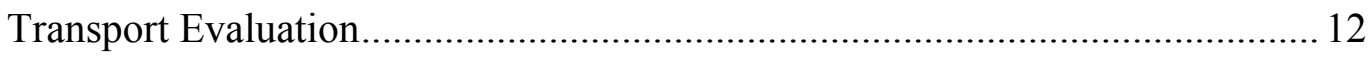

Environmental Conditions and Fish Passage ............................................................. 14

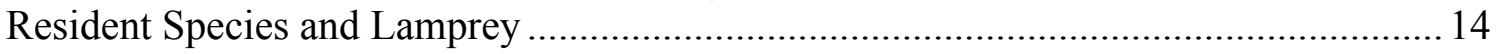

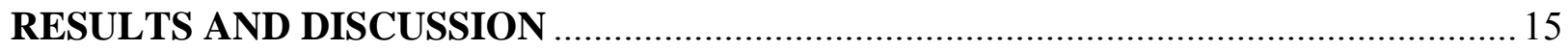

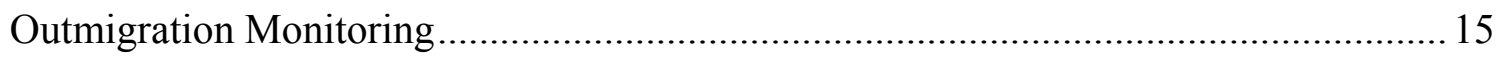

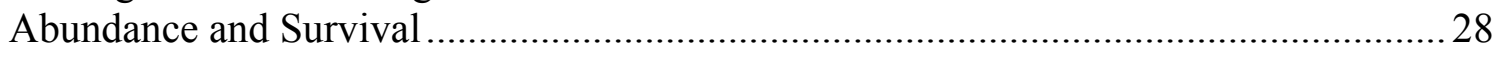

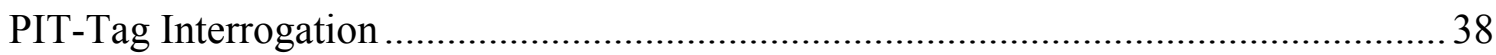

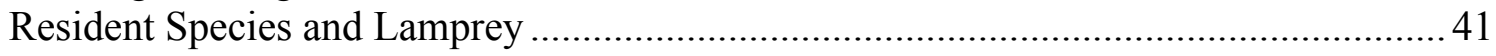

CONCLUSIONS AND RECOMMENDATIONS ................................................... 44

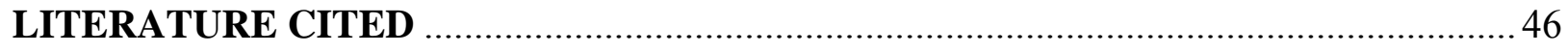

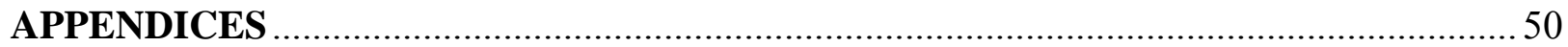




\section{LIST OF TABLES}

Table 1. Mean survival and capture probabilities used to estimate tag sizes

Table 2. Current and proposed tag sizes needed to obtain survival rates to TMFD and JDD with $5 \%, 10 \%$ or $20 \%$ coefficient of variation for hatchery-reared and naturallyproduced juvenile salmonids.

Table 3. Natural summer steelhead smolt size and age upon emigration from the Umatilla River, 1995-2006

Table 4. Natural Chinook salmon smolt size upon emigration from the Umatilla River, 1995-2006

Table 5. Condition summary for hatchery and natural smolts sampled at TMFD, 20042006.

Table 6. Unknown source and sampling mortality summary for hatchery and natural smolts sampled at TMFD, 2004-2006

Table 7. Species-specific mean efficiency estimates for the juvenile bypass/trapping facility at West Extension Canal, 1999-2006

Table 8. Abundance estimates of natural Chinook salmon and steelhead smolts emigrating from the Umatilla River, 1995-2006

Table 9. In- and out-of-basin survival estimates for juvenile natural salmon and steelhead emigrating from the Umatilla River, 1999-2006

Table 10. In- and out-of-basin survival estimates for juvenile hatchery salmon and steelhead released in the Umatilla River, 1995-2006. Standard errors are in parentheses

Table 11. In- and out-of-basin survival estimates for standard- and fall-transferred spring Chinook salmon reared at Umatilla Fish Hatchery, 1999-2006

Table 12. In- and out-of-basin survival estimates for March and April released yearling fall Chinook salmon reared at Bonneville Fish Hatchery, 1999-2006.

Table 13. In- and out-of-basin survival estimates for March and April released juvenile coho salmon acclimated and released at RM 56, 2001-2006

Table 14. In- and out-of-basin survival estimates for subyearling fall Chinook salmon reared at Umatilla Fish Hatchery and acclimated and released at RM 73.5 or direct stream released at RM 48.5, 1999-2006. 
Table 15. In- and out-of-basin survival estimates for juvenile summer steelhead reared at

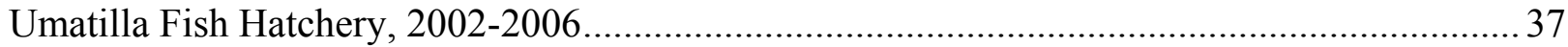

Table 16 Number of non-target species and Pacific lamprey captured and length summary statistics, Umatilla River, 2004 -2006.. 


\section{LIST OF FIGURES}

Figure 1. Map of general study area of Pacific Northwest USA and detailed map of the trapping and tagging locations from the Umatilla River

Figure 2. Emigration timing for natural and hatchery spring Chinook salmon smolts in the Umatilla River, 2000-2006

Figure 3. Emigration timing for natural and hatchery subyearling fall Chinook salmon smolts in the Umatilla River, 2000-2006

Figure 4. Emigration timing for natural and hatchery summer steelhead smolts in the Umatilla River, 2000-2006

Figure 5. Cumulative and percent abundance of summer steelhead emigrating from the Umatilla River in 2006.

Figure 6. Mean weekly flows and temperatures measured in the Umatilla River compared to 10,50, and 90\% emigration dates of Chinook salmon, coho salmon, and summer steelhead.

Figure 7. Passage route selection at TMFD by PIT tagged production released salmonids associated with canal diversion at West Extension Canal

Figure 8. Relationship between canal diversion rate and efficiency of the juvenile bypass/trapping facility

Figure 9. Recapture rate and travel speed for PIT tagged hatchery subyearling fall Chinook salmon released in 2004 .

Figure 10. Recapture rate and travel speed for PIT tagged hatchery spring Chinook salmon released in 2005

Figure 11. Weekly secchi depth, water temperature, and river flow, Umatilla River, 2004 -2006 .

Figure 12. Smolt-per-spawner estimates of natural spring Chinook salmon, fall Chinook salmon and summer steelhead in the Umatilla River, BY1993-2004.

Figure 13. Relationship between total spawning escapement and smolts produced per spawner for natural summer steelhead between brood years 1993-2004 ................................................... 31

Figure 14. Natural summer steelhead smolts-per-female by brood year, 1993-2004...................32

Figure 15. Natural summer steelhead egg-to-smolt survival by brood year, 1993-2004 .32 
Figure 16. Smolt-to-adult return rate of natural summer steelhead in the Umatilla River, 1995-2002

Figure 17. East and West bank PIT tag detection arrays at Three Mile Falls Dam....................39

Figure 18. PIT tag detection array within the trap at the juvenile bypass/trapping facility in $1999,2000,2004$, and 2006

Figure 19. PIT tag detection array within the outfall at the juvenile bypass/trapping facility in 2005 and 2006

Figure 20. PIT tag detection array within the viewing window at the adult fish ladder in 2000 and 2006 .

Figure 21. Improved detection efficiency of natural summer steelhead in the adult fish ladder at Three Mile Falls Dam, following installation of the multiplexer and upgraded antenna array, April 2006.

Figure 22. Capture timing of larvae, metamorphosed, and adult Pacific lamprey and nontarget species in the Umatilla River, 2004-2006. 


\section{LIST OF APPENDICES}

Appendix A. Auxiliary information from outmigration studies ..........................................50

Appendix B. Three Mile Falls Dam permanent adult ladder detector: design plans and

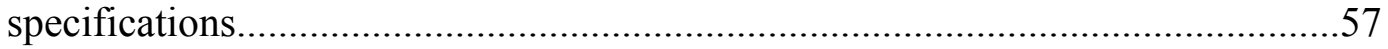

Appendix B-1. Design Description ...........................................................................58

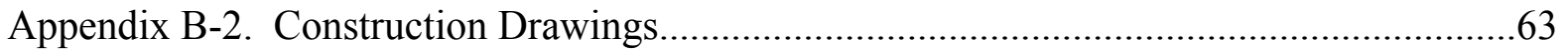

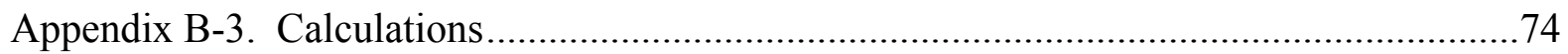

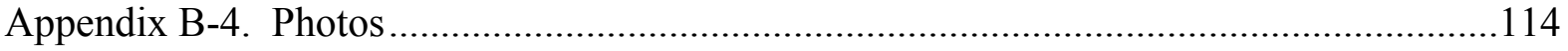




\section{EXECUTIVE SUMMARY}

This report summarizes activities conducted by the Oregon Department of Fish and Wildlife's Juvenile Outmigration and Survival M\&E project in the Umatilla River subbasin between 20042006. Information is used to make informed decisions on hatchery effectiveness, natural production success, passage improvement and flow enhancement strategies. Data collected includes annual estimates of smolt abundance, migration timing, and survival, life history characteristics and productivity status and trends for spring and fall Chinook salmon, coho salmon and summer steelhead. Productivity data provided is the key subbasin scale measure of the effectiveness of salmon and steelhead restoration actions in the Umatilla River. Information is also used for regional planning and recovery efforts of Mid-Columbia River (MCR) ESAlisted summer steelhead. Monitoring is conducted via smolt trapping and PIT-tag interrogation at Three Mile Falls Dam.

\section{Project Objectives}

The Umatilla Juvenile Outmigration and Survival Project was established in 1994 to evaluate the success of management actions and fisheries restoration efforts in the Umatilla River Basin. Project objectives for the 2004-2006 period were to: (1) operate the PIT tag detection system at Three Mile Falls Dam (TMFD), (2) enhance provisional PIT-tag interrogation equipment at the east bank adult fish ladder, (3) monitor the migration timing, abundance and survival of naturally-produced juvenile salmonids and trends in natural production, (4) determine migration parameters and survival of hatchery-produced fish representing various rearing, acclimation and release strategies, (5) evaluate the relative survival between transported and non-transported fish, (6) monitor juvenile life history characteristics and evaluate trends over time, (7) investigate the effects of river, canal, fishway operations and environmental conditions on smolt migration and survival, (8) document the temporal distribution and diversity of resident fish species, and (9) participate in planning and coordination activities within the basin and dissemination of results.

\section{Significant Findings and Accomplishments}

Outmigration Monitoring: Results indicate migration patterns for hatchery salmonids are similar to those of natural salmonids, although the magnitude of smolt emigration varied significantly. Median emigration of natural summer steelhead is roughly one week earlier then their hatchery counterparts. Median emigration of natural fall Chinook salmon is approximately one week later than hatchery conspecifics. Correlations between migration timing and environmental factors are species dependent and are variable from year to year.

Size and age at emigration for Umatilla salmon and summer steelhead is similar to surrounding basins. Spring Chinook salmon emigrate as yearlings, fall Chinook as subyearlings and summer steelhead at a broad distribution of ages.

PIT tag data suggests, passage route selection at TMFD is influenced by canal diversion. When West Extension Canal is operating, the majority of salmonids emigrate past TMFD using the juvenile bypass. When the canal is not operating, juvenile fish passage is more prevalent 
through the east bank adult fish ladder. During high flow events most fish appear to pass over the crest of the dam.

Smolt Abundance: Abundance of summer steelhead has fluctuated since 1995, however trends reflect little or no change in productivity. The average annual smolt production of Umatilla summer steelhead is 50,217 (CI +/- 6,116). Smolt production of spring Chinook salmon has ranged between 8,458 and 14,159 for outmigration years 2004-2006. Production of fall Chinook salmon has fluctuated dramatically over the same period $(12,781$ to 107,858$)$.

Juvenile Survival: Overall performance of hatchery smolts has been variable and less then satisfactory for most species. In-basin survival has averaged $31 \%$ for hatchery-reared coho salmon, 38\% for summer steelhead, 59\% for subyearling fall Chinook salmon, $62 \%$ for spring Chinook salmon, and 70\% for yearling fall Chinook salmon. Enhanced detection capabilities at TMFD and application of the SURPH model in 2005 has provided more robust estimates of survival.

Survival from TMFD to John Day Dam (JDD) of naturally-reared spring Chinook salmon, fall Chinook salmon and summer steelhead, has averaged $65 \%, 16 \%$ and $59 \%$, respectively, between 1999-2006. Egg-to-smolt survival (ESS) rates for naturally-produced summer steelhead averaged $0.77 \%$ for brood years (BY) 1993-2004. Umatilla summer steelhead continue to have similar smolt-to-adult return (SAR) rates compared to steelhead in surrounding basins. The mean SAR rate for naturally-produced Umatilla summer steelhead between outmigration years 1995-2002, was 3.53\%.

Smolt-per-spawner (SPS) estimates for Umatilla salmon and steelhead are considerably lower than that of surrounding basins. Mean SPS for BY 1993-2004 were 27.1 for natural spring Chinook salmon, 75.8 for natural fall Chinook salmon and 26.6 for natural summer steelhead. The average number of summer steelhead smolts produced per female (SPF) between BY's 1993-2004 was 40.0.

PIT tag interrogation: PIT-tag interrogation has been successful and incrementally improved at TMFD since 1999. Over the past 3 years, equipment has been upgraded to improve system performance, reliability and remote system monitoring. Three detection arrays are currently in place at TMFD; two within the juvenile bypass and one in the adult fish ladder. Detection efficiency at the 3 sites ranges from $47.9 \%$ to $99.9 \%$. Tag information from all 3 sites is coordinated to remotely upload at one central location.

Engineered design plans and specifications for a permanent adult ladder detection system were completed in 2005 . 


\section{INTRODUCTION}

The Umatilla River historically supported large runs of salmon (Oncorhynchus spp.), steelhead (O. mykiss), and Pacific lamprey (Lampetra tridentata) for productive Tribal and recreational fisheries. By the early 1920s, these runs were decimated. The extirpation and degradation of salmon and steelhead populations in the Umatilla River was a result of extensive agricultural development and associated water withdrawals, habitat destruction, water quality degradation, passage problems, over-harvest and habitat loss both inside and outside of the basin (Saul et al. 2001).

In 1980, the Northwest Power Act served as a springboard for focusing attention and effort on restoring salmon and steelhead populations throughout the Columbia River basin. A multitude of projects were initiated, to help address rehabilitation efforts and achieve fisheries restoration program goals (NPPC 1984, 1987, 1994 and 2000). Rehabilitation of Umatilla fish populations called for restoration of spring and fall races of Chinook salmon (O. tshawytscha), coho salmon (O. kisutch), and supplementation of summer steelhead (CTUIR and ODFW 1989). Proposed measures included passage improvements at irrigation diversion dams, habitat restoration, hatchery production, construction of acclimation facilities, flow enhancement, and fish transport during low flows (CTUIR and ODFW 1984; ODFW 1986, CTUIR and ODFW 1989).

Monitoring and research efforts to evaluate Umatilla restoration and enhancement projects were implemented in the late 80's and early 90's. The Umatilla Passage Evaluation study was established in 1989 to evaluate passage of juvenile and adult salmonids following construction of canal screening and bypass facilities (Cameron et al. 1997). The Umatilla Hatchery Monitoring and Evaluation (M\&E) project was implemented in 1990, following construction of the Umatilla Hatchery (Grant et al. 2007). In 1991, the Natural Production M\&E Project was initiated to monitor salmon reintroduction efforts and the effects of supplementation on natural summer steelhead populations. These efforts, however, did not include a comprehensive evaluation of the migration success, abundance and survival of hatchery-reared and naturally-produced juvenile salmonids in the Umatilla River.

Long-term trend monitoring of juvenile abundance and survival was considered necessary as habitat was improved, flow enhanced, natural production expanded, and hatchery practices adjusted. Monitoring and sampling at the basin level were considered crucial for gathering necessary information on life history characteristics, population abundance, and life-stage specific survival of natural salmonids. Specific questions still remained regarding in-basin survival and passage problems for juvenile fish, production potential for natural populations, and aquatic community health. Furthermore, as production strategies evolved, results needed to be monitored and merits evaluated to help guide management decisions.

In 1994, the Umatilla Juvenile Outmigration and Survival M\&E project was established in attempt to address some of the above noted concerns. Outmigration monitoring was originally conducted via branding and color-marked fish (Knapp et al. 1996, 1998a, 1998b). The advent of PIT tag technology at the John Day Dam in 1998, however prompted the use of PIT tags (400 $\mathrm{kHz}$ ) in the Umatilla Basin the same year. In 2000, detection equipment was upgraded to a 134 $\mathrm{kHz}$ system, to further enhance monitoring capabilities. Additional upgrades have recently been 
implemented to improve performance, reliability and remote system monitoring. Eight years of PIT-tag interrogation at TMFD has provided increasingly accurate estimates of juvenile abundance, migration timing and survival, while minimizing the number of fish handled.

The Umatilla Outmigration and Survival Project is one of three intimately-linked Research, Monitoring and Evaluation (RM\&E) projects designed to evaluate the success of adaptive management strategies and restoration efforts in the Umatilla River. Data collected is used to resolve critical uncertainties identified in the Umatilla Subbasin Plan (Debano et al. 2004) and Umatilla RM\&E Plan (CTUIR and ODFW 2006). Outmigration and Survival activities complement and support those carried out by the Umatilla Hatchery M\&E project (BPA Project 199000500) and the Umatilla Natural Production M\&E project (BPA Project 199000501).

This report summarizes work performed by the ODFW's Umatilla Juvenile Outmigration and Survival M\&E project between 2004 and 2006. Information gathered has helped clarify the status and trends of juvenile salmonids in the Umatilla River, provided insight into the effects of river, canal flow, water temperature, and other environmental variables on fish passage and survival, helped evaluate juvenile life history characteristics and trends in natural production and aided in monitoring the movement of juvenile Pacific lamprey and resident fish. 


\section{STUDY AREA}

The Umatilla River basin is located within Umatilla and Morrow counties of northeast Oregon (Figure 1). Draining an area of 2,290 square miles, it flows in a northwesterly direction into RM 289 of the Columbia River. The uppermost reaches of the basin are situated along the steep timbered slopes of the Blue Mountains of the Umatilla National Forest (Saul et al. 2001). The remainder of the drainage lies within the broad upland plain of the Deschutes-Umatilla Plateau (Contor and Kissner 2000).

The Umatilla River contains a mainstem length of 115 miles (Contor et al 2000) and is fed by eight major tributaries. Elevation ranges from nearly 5,800 feet at the headwaters, to 260 feet at its confluence with the Columbia River (Saul et al. 2001). Identified by hydrologic unit number 17070103 (US Geological Survey 1989), it receives a mean annual precipitation of 10 to 50 in./yr within the lower and upper basin, respectively (Contor et al 2000; Saul et al. 2001). The Umatilla River basin lies within Oregon's North Central bio-geoclimatic zone (Zone 6).

The upper portion of the basin encompasses a section of the Umatilla National Forest as well as 172,000 acres of tribal land (Confederated Tribes of the Umatilla Indian Reservation, CTUIR). The majority of the land in the Umatilla basin is privately owned (82\%), with the remainder being divided amongst the State of Oregon, Umatilla County, various cities and CTUIR (Saul et al. 2001).

Project activities are concentrated in the lower Umatilla River mainstem, between RM 1.2 and RM 3.7 (Figure 1). The juvenile screening facility (incline plane trap and PIT tag detection system) is located within West Extension Canal off TMFD (RM 3.7). The secondary trapping location (rotary-screw trap) is situated in a deep pool beneath the Interstate 82 Bridge (RM 1.2). Sampling is conducted year round, with operations focusing at RM 3.7 between February and July and at RM 1.2 from October to January. Sampling at RM 1.2 was discontinued in 2005.

Release sites for trap and haul operations and trap efficiency tests are located at various points along the Umatilla mainstem. More specifically, the sites are situated between the mouth and RM 27.2 (Westland Diversion Dam).

The average monthly discharge within the lower river varies from a low of $23 \mathrm{cfs}$ in the summer (July) up to 1,095 cfs during spring runoff (April). Water temperatures have been known to peak at lethal levels of between $18^{\circ} \mathrm{C}$ and $27^{\circ} \mathrm{C}$ (Saul et al. 2001). 


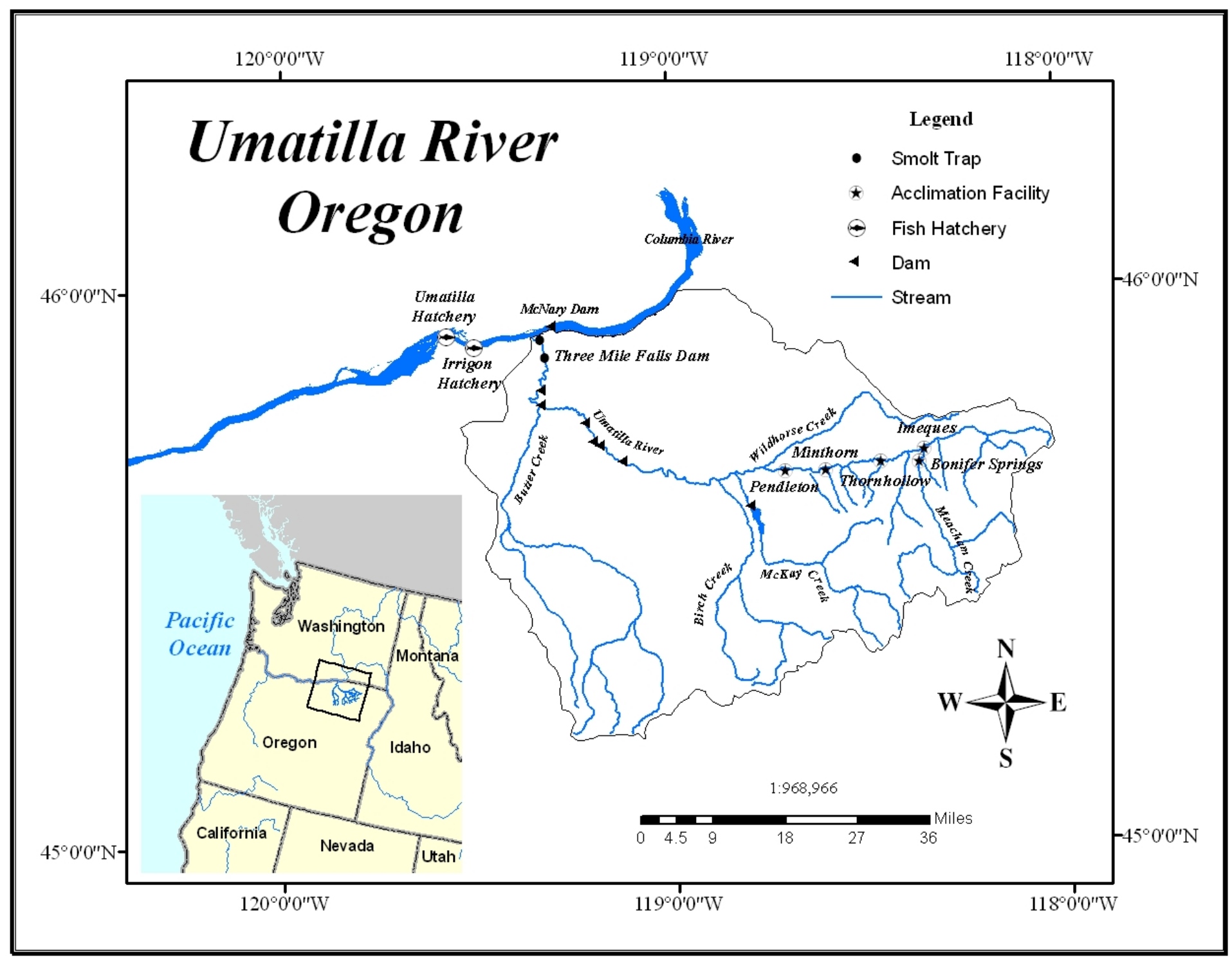

Figure 1. Map of general study area of Pacific Northwest, U.S.A. and detailed map of the trapping and tagging locations from the Umatilla River. 


\section{METHODOLOGY}

\section{Outmigration Monitoring}

\section{Fish Trapping and PIT Tag Operations}

Outmigration monitoring was conducted via smolt trapping and PIT tag interrogation at TMFD (RM 3.7). An inclined plane trap set in the juvenile bypass facility at West Extension Canal was used to capture emigrating salmonids. Trapping was conducted between February and June to coincide with the primary smolt emigration period. This was also the primary period when water was diverted into West Extension Canal. In 2004, a rotary screw trap was also operated from October to January in attempt to capture early/late natural migrants. The rotary screw trap was located beneath the I-82 bridge on the lower Umatilla River (RM 1.2).

PIT-tagged fish were interrogated at TMFD via one of three antenna arrays; in the juvenile bypass trap, at the juvenile bypass outfall or the east bank adult fish ladder. Detection data was stored on a PC and automatically uploaded to the PIT Tag Information System (PTAGIS) database on a daily basis via the Minimon program and modem. A full description of PIT-tag interrogation, marking, and file management operations can be found in White et al. 2004.

Approximately 1,200 natural salmonids were PIT-tagged annually to monitor trends in natural production. As many as 14,679 hatchery-reared fish were also tagged for juvenile outmigration and survival monitoring.

\section{Fish Condition and Life History Characteristics}

Regardless of trap type or location, all salmonids captured were anesthetized with a stock solution of MS-222 (40 mg/l) prior to sampling. Fish were enumerated by species, race, and origin. Origin was categorized as "natural" or "hatchery" based on the presence/absence of a fin clip, wire tag, or the appearance of wear on the dorsal or ventral fins. Race of natural Chinook salmon was categorized as spring or fall using body morphology, length and age characteristics.

All natural smolts and a subsample of hatchery smolts were examined to assess age, size, condition, health and smolt status at emigration. Size at emigration was quantified from fish captured in traps for each species of salmonid. Fork length was recorded to the nearest $\mathrm{mm}$ and a t-test for two independent samples performed to determine if there was a significant difference among length distributions of hatchery and natural fish. Scale samples on a subsample of natural summer steelhead were collected for age analysis and applied to smolt abundance estimates to determine age class contributions to the emigrating population. Natural Chinook salmon scales were collected to assist in the identification of spring and fall Chinook salmon. Scales were mounted on mylar strips and examined under a microfiche at $24 \mathrm{X}$ or greater magnification to discern annuli patterns reflecting freshwater age. Developmental (smoltification) stage was ranked as parr, intermediate, or smolt based on brightness and the absence or presence of parr marks. 
Condition was characterized as the proportion of cumulative scale loss evident on the fish at the time of emigration Fish condition was partitioned into one of three categories: good $(<3 \%)$, partially descaled $(3-20 \%)$, or descaled $(>20 \%)$ following criteria used by the Umatilla Hatchery Monitoring and Evaluation project (Keefe et al. 1994). Juvenile fish health was monitored by daily examination of randomly selected emigrants per species/origin type for body injuries, external parasites, bird marks, obvious fungal infections of the body surface, and signs of potential disease. Fish mortalities were noted by species and identified as being from an unknown source or a direct result of sampling activities. All natural fish that died from an unknown cause and some diseased and dead hatchery fish were forwarded to the ODFW Fish Pathology Lab. Analysis of samples followed standard protocols defined in the latest edition of the American Fisheries Society "Fish Health Blue Book" (procedures for the detection and Identification of Certain Fish Pathogens).

\section{Migration Parameters}

Migration parameters were analyzed for hatchery juvenile salmonids using PIT tag detections at West Extension Canal. Parameters included emigration timing, pattern, duration, and travel speed for each species. Peak movement was determined by selecting the date when the maximum number of tagged emigrants were detected. Median emigration was the date when $50 \%$ of the tag detections were observed and diel movement was determined by the percentage of fish detected within hourly blocks of time. Travel speed was calculated for tagged fish detected at West Extension Canal using the following equation:

$$
\mathrm{TS}=(\mathrm{RM}-3.7) /(\mathrm{D}-\mathrm{R})
$$

where $\mathrm{TS}=$ travel speed, $\mathrm{RM}=$ river mile of release, $\mathrm{D}=$ date and time of detection at West Extension Canal, and $\mathrm{R}=$ date and time of forced release. Median travel speed was calculated for each hatchery release group. Median rather than mean travel speeds were computed because detection distributions tended to be skewed. Negative travel speed estimates due to early movement from acclimation ponds during volitional release periods were omitted from the analysis. Tagged fish collected during fish sampling operations were also removed due to the inability to assign an accurate time of recapture.

The number of fish captured at the rotary-screw trap and West Extension Canal was expanded to compare the timing of natural and hatchery smolts emigrating from the Umatilla River using the following equation:

$$
\mathrm{C}_{\mathrm{w}}=\sum \frac{\left(\mathrm{C}_{\mathrm{d}} / \mathrm{R}_{\mathrm{d}}\right)}{\mathrm{P}_{\mathrm{w}}}
$$

where, $\mathrm{C}_{\mathrm{w}}=$ estimated weekly number of fish captured at the rotary-screw trap or moving through the juvenile bypass, $C_{d}=$ daily number fish captured, $R_{d}=$ daily sample rate, $P_{w}=$ ratio of time sampled to unsampled within the week. Weekly estimates were summed to derive and then plotted as a proportion of the season total. Cumulative frequencies were calculated and the week of the $10^{\text {th }}, 50^{\text {th }}$, and $90^{\text {th }}$ percentiles were determined. The Kolmogorov-Smirnov test was 
performed to assess statistical differences in the emigration timing of hatchery and natural summer steelhead.

Paired release tests were completed at the juvenile bypass facility in 2004 and 2005 to evaluate temporal and spatial variability in recapture rates and travel speeds of fish previously exposed to the trap (run-of-river) compared to fish with no prior trap exposure (naïve). In 2004, three paired releases of approximately 60 PIT tagged fish each were made at two separate locations upstream of the juvenile bypass facility; the waste water treatment plant (1.5 miles upstream of the trap) and the canal headgates (230 feet upstream of the trap). Run-of-river fish were collected at West Extension Canal, while naïve fish were collected from upriver acclimation sites. In 2005, similar tests were conducted however comparisons between run-of-river and naïve fishes were not made. A two-sample Proportion Test was used to test for differences $(\alpha=0.05)$ in recapture rates within and among releases. The travel times of individual fish were $\log _{\mathrm{e}}$ transformed to meet the assumption of normality and ANOVA was used to test for differences within and among releases. When significant differences $(\alpha=0.05)$ were found a pairwise comparison using the Fisher's test for least significance difference was conducted. Associations between specific abiotic variables and recapture rates were assessed using regression analysis.

\section{Abundance and Survival}

\section{Trap Efficiencies}

To calibrate the collection efficiency of the traps and estimate outmigrant abundance, groups of 25 to 60 fish per species were collected, PIT-tagged, and released 1.3 miles upstream of the trap for recapture. Fish were PIT-tagged according to standards outlined in the PIT Tag Marking Procedures Manual (CBFWA, PIT Tag Steering Committee, 1999). Tests were conducted 2 times a week for each species while sufficient numbers of fish were being captured. Tagged fish were held for 24 hours prior to release to assess tagging mortality, tag loss, and to determine the probability of survival of individual release groups. The probability of survival and estimated survival of tagged fish released was calculated as:

$$
\begin{gathered}
\mathrm{s}=\mathrm{L} / \mathrm{H}, \\
\text { and } \\
\mathrm{M}=\mathrm{N}(\mathrm{s})
\end{gathered}
$$

where $\mathrm{s}=$ probability of survival, $\mathrm{L}=$ number of live tagged fish after holding, $\mathrm{H}=$ initial number of tagged fish, $\mathrm{M}=$ estimated number of tagged fish released, and $\mathrm{N}=$ total number of tagged fish released. Tagged fish that died or dropped their tags prior to release were removed from the release group. Tag retention and fish survival for all factors other than tagging were assumed to be $100 \%$ after release. It was also assumed that all marked and unmarked smolts migrated downstream independently of one another and had equal catchability. Specific details regarding tagging, holding and fish transport operations can be found in White et al. 2004.

Recaptured fish were enumerated by species/origin and trap efficiency estimates computed using the following formula: 


$$
\mathrm{TE}=\mathrm{R} / \mathrm{M}
$$

where, $\mathrm{TE}=$ estimated trap efficiency, $\mathrm{R}=$ number of recaptured fish, and $\mathrm{M}=$ estimated number of tagged fish released. Separate trap efficiency estimates within a species were compared using chi-square analysis. If estimates were not significantly different $(\alpha=0.05)$ they were pooled. Pooling was continued until a significant difference was determined or no trend of change was evident.

\section{Smolt Abundance}

Smolt emigrant abundance was defined as the number of smolts leaving the Umatilla River or reaching TMFD. Abundance was calculated for natural emigrants only and is the key component required to address critical uncertainties surrounding in-basin productivity and natural production capacity. Smolt abundance was derived based on the number of fish collected at lower river traps and the estimated trap efficiency. Abundance of fish passing TMFD was estimated as:

$$
\begin{gathered}
\mathrm{A}=\mathrm{B} / \mathrm{TE} \\
\text { and } \\
\mathrm{B}=(\mathrm{C} / \mathrm{T})
\end{gathered}
$$

where, $\mathrm{A}=$ estimated number of outmigrants, $\mathrm{B}=$ estimated number of fish that passed through the trap (total passage), $\mathrm{TE}=$ estimated trap efficiency, $\mathrm{C}=$ sample rate, and $\mathrm{T}=$ proportion of time sampled.

Emigrant abundance was estimated on a monthly basis and then summed to derive the total number of outmigrants for the season. For months where trap efficiencies of natural species were not available or were sparse, trap efficiency estimates from hatchery conspecifics were used. If hatchery conspecifics were not available for a particular month, efficiency estimates from the month before or month after were used. The Bootstrap method (Efron and Tibshirani 1986; Thedinga et al. 1994) with 1,000 iterations was used to derive a variance and 95\% confidence intervals for abundance estimates.

The downstream movement of Chinook salmon fry $(<45 \mathrm{~mm})$ and subyearling coho salmon (45 - $105 \mathrm{~mm}$ ) was assumed to be a natural dispersal mechanism to help distribute fish among the suitable rearing habitat and thus were not classified as emigrating smolts. Freshwater age-0 summer steelhead $(<75 \mathrm{~mm})$ were assumed not to be outmigrants based on the fact that a subyearling life history pattern has never been detected on scale samples collected from adult steelhead escaping to the Umatilla River. 


\section{Smolt-Yield-Per-Spawner}

Smolt-yield-per-spawner was estimated to measure the productivity of naturally spawning hatchery and natural fish in the Umatilla River basin. Estimates were calculated using the following equation:

$$
\mathrm{SYS}=\mathrm{A} / \mathrm{NS}
$$

where, SYS = smolt-yield-per-spawner, A = estimated smolt abundance at TMFD, and NS = number of potential spawners.

The number of spawners for spring Chinook salmon was estimated by multiplying the total number of redds counted during spawning ground surveys by two. Fall Chinook salmon spawner estimates were computed using the female spawning escapement at TMFD plus the number of female outplants times two. Escapement data from TMFD was used to determine the number of spawners for natural summer steelhead.

\section{Smolts -Per-Female}

Smolts-per-female were estimated for natural summer steelhead using the female spawning escapement and estimated smolt abundance at TMFD. Smolt yield was proportionately partitioned by brood year based on freshwater age composition. Age structure was determined from scale analysis of 100 natural adult returns per year to TMFD (1991-2000). Missing scale data for BY's 2001-2004 was reconstructed using the mean freshwater age composition from BY 1991-2000.

\section{Smolt Survival}

Survival was estimated for hatchery and natural salmonids to assess in and out-of-basin loss by species and life-stage. Survival estimates were also generated to support hatchery production monitoring and evaluation of optimal rearing and release strategies. Mark-recapture methodology utilizing PIT tags and subsequent detections at TMFD and Columbia River dams was used to calculate survival. Hatchery fish were PIT-tagged at the hatchery or acclimation facilities prior to release. Natural fish were captured and tagged at TMFD during smolt trapping operations.

Survival to TMFD and JDD was estimated using the SURPH 2 model (v 2.1). SampleSize 1.3 was used to determine tag sizes needed to estimate survival rates at desired levels of precision (Tables 1 and 2; Lady et al. 2001). A 20\% CV provided the most realistic sample sizes under current operations and funding conditions. 
Table 1. Mean survival and capture probabilities used to estimate tag sizes.

\begin{tabular}{lcccccc}
\hline & \multicolumn{2}{c}{ Survival probability } & & \multicolumn{2}{c}{ Capture probability } & \\
\cline { 2 - 3 } Species & $\begin{array}{c}\text { Release } \\
\text { to TMFD }\end{array}$ & $\begin{array}{c}\text { TMFD to } \\
\text { JDD }\end{array}$ & & $\begin{array}{c}\text { Release } \\
\text { to TMFD }\end{array}$ & $\begin{array}{c}\text { TMFD to } \\
\text { JDD }\end{array}$ & $\begin{array}{c}\text { Final period } \\
\text { survival/capture }\end{array}$ \\
\hline Hatchery spring Chinook salmon & 0.62 & 0.56 & & 0.12 & 0.35 & 0.18 \\
Hatchery yearling fall Chinook salmon & 0.69 & 0.67 & 0.24 & 0.30 & 0.15 \\
Hatchery subyearling fall Chinook salmon & 0.61 & 0.53 & 0.46 & 0.32 & 0.11 \\
Hatchery summer steelhead & 0.36 & 0.55 & & 0.30 & 0.27 & 0.21 \\
Natural spring Chinook salmon & 0.34 & 0.68 & & 0.21 & 0.39 & 0.18 \\
Natural fall Chinook salmon & -- & 0.15 & & -- & 0.70 & 0.11 \\
Natural summer steelhead & 0.34 & 0.57 & 0.28 & 0.34 & 0.18 \\
\hline
\end{tabular}

$\overline{{ }^{1}}$ Derived from Umatilla fish PIT tagged and detected between 1999-2005; Survival and capture probabilities calculated through SURPH.

Table 2. Current and proposed tag sizes needed to obtain survival rates to TMFD and JDD with 5\%, $10 \%$ or $20 \%$ coefficient of variation $(\mathrm{CV})$ for hatchery-reared and naturally-produced juvenile salmonids.

\begin{tabular}{|c|c|c|c|c|c|c|c|}
\hline \multirow[b]{3}{*}{ Species } & \multirow{3}{*}{$\begin{array}{c}\text { Current tag } \\
\text { sizes }\end{array}$} & \multicolumn{6}{|c|}{ Proposed tag sizes } \\
\hline & & \multicolumn{3}{|c|}{ Release to TMFD } & \multicolumn{3}{|c|}{ TMFD to JDD } \\
\hline & & $5 \% \mathrm{CV}$ & $10 \% \mathrm{CV}$ & $20 \% \mathrm{CV}$ & $5 \% \mathrm{CV}$ & $10 \% \mathrm{CV}$ & $20 \% \mathrm{CV}$ \\
\hline Hatchery spring Chinook salmon & 2,000 & 14,000 & 3,600 & 900 & 25,400 & 6,200 & 1,600 \\
\hline Hatchery yearling fall Chinook salmon & 600 & 5,200 & 1,300 & 400 & 16,800 & 4,200 & 1,000 \\
\hline Hatchery subyearling fall Chinook salmon & 1,200 & 3,200 & 800 & 200 & 24,500 & 6,200 & 1,500 \\
\hline Hatchery summer steelhead & 900 & 9,500 & 2,400 & 600 & 30,700 & 7,500 & 1,800 \\
\hline Natural spring Chinook salmon & -- & 9,500 & 2,400 & 600 & 21,600 & 5,400 & 1,400 \\
\hline Natural fall Chinook salmon & -- & 6,700 & 1,700 & 400 & 30,200 & 6,600 & 1,700 \\
\hline Natural summer steelhead & -- & 9,700 & 2,300 & 600 & 27,400 & 6,700 & 1,700 \\
\hline
\end{tabular}




\section{Egg-to-Smolt Survival}

Egg-to-smolt survival was estimated for natural summer steelhead as a measure of life-stage specific survival. Egg-to-smolt survival was computed as:

$$
\begin{gathered}
\mathrm{ESS}=\mathrm{A} / \mathrm{ED} \\
\text { and } \\
\mathrm{ED}=(3979 * \mathrm{~S} 1)+(6965 * \mathrm{~S} 2)
\end{gathered}
$$

where, ESS = egg-to-smolt survival, A = estimated smolt abundance at TMFD, and ED = egg deposition of salt-1 [S1] and salt-2 [S2] females available to spawn. Smolt abundance was partitioned by brood year based on freshwater age composition. Age classification of female spawners was determined from brood fish collected between 1993-2004.; S1<600mm FL and S2 $>600$ mm FL (BY 1993-2004).

\section{Smolt-to-Adult Return}

Smolt-to-adult return for natural summer steelhead was estimated as:

$$
\mathrm{SAR}=\mathrm{AR} / \mathrm{A}
$$

where $\mathrm{SAR}=$ smolt-adult return, $\mathrm{AR}=$ total number of adult returns to TMFD, $\mathrm{A}=$ estimated smolt abundance. Smolt abundance was derived from annual outmigrant estimates at TMFD and partitioned by age structure. The number of adult returns (salt-1, salt-2, and salt-3 fish) were aligned by smolt outmigration year using adult counts at TMFD and scale analysis.

\section{Transport Evaluation}

Transport evaluation tests were not conducted in 2004 due to logistical constraints and unfavorable environmental conditions. Transport evaluation tests were discontinued in 2005.

Transport evaluation tests were conducted to evaluate the relative survival of transported versus non-transported fish. In the past, transported (treatment) fish were hauled to the mouth of the Umatilla River and released. Non-transported (control) fish were released directly into the river beneath the Stanfield Bridge (RM 23). 


\section{Environmental Conditions and Fish Passage}

Environmental variables including river flow, flow augmentation, water temperature, and water clarity were monitored and analyzed using associative and time-series analysis to characterize conditions in the Umatilla River and to assess their effects on emigration timing and fish passage. Daily river flow, discharge from McKay Reservoir, and water temperature data were obtained from the USBR Hydromet Archives: http:/www.usbr.gov/pn/hydromet/. Weekly mean flow from the Umatilla gauging station (RM 2.1) and water temperature from the Yoakum gauging station (RM 37.6) was plotted against time. Missing flow or temperature records were estimated using associative models with upstream gauging stations or by using an average of the day before and after the missing measurement. Water clarity was measured daily to the nearest $0.1 \mathrm{~m}$ using a 7-in-diameter secchi disk at RM 1.2 or 3.7 and weekly mean secchi depth was plotted against time. Weekly mean discharge for flow augmentation from McKay Reservoir and water exchange as a proportion of total flow at the Umatilla gauge was plotted against time and overlaid with cumulative smolt emigration.

The relationship between specific abiotic variables and the daily proportion of emigrants passing a trap site was tested using the Spearman rank correlation test. Abiotic variables included river flow, water temperature, and water clarity. Abiotic variables were the average of the mean of the day before and the day of passage. The time period used for the analysis was between the days when the first and last emigrant was observed. Flow and temperature data from the Yoakum gauging station (RM 37.6) and water clarity measured at RM 1.2 or 3.7 were utilized for the analysis. Any missing flow or temperature records were estimated by taking the average of the mean daily flow or temperature three days prior and three days after the missing record.

Multiple regression techniques were used to analyze recapture rates of PIT tagged fish in an attempt to determine factors that influence route selection at Three Mile Falls Dam. Least squares multiple regression was used to test for association between specific abiotic variables and the efficiency of the juvenile bypass/trapping facility. Abiotic variables included water temperature, river flow, water clarity, diversion rate, volume of water diverted into the facility and facility entrance velocity. Arcsine transformed trap efficiency estimates (see Trap Efficiencies) were used as the dependent variable. Mean values of abiotic variables based on the day of and the day after the trap efficiency releases were calculated and used as the independent variables. Flow and temperature variables from the Umatilla gauging station were utilized for the analysis and canal diversion data was obtained from a gauging station located immediately downstream (2001 - 2006) of the canal check gates . Canal diversion rate was calculated by dividing the daily canal flow by the daily river flow. Daily river flow was calculated by adding the Umatilla gauge reading and the daily canal flow.

\section{Resident Species and Lamprey}

Resident fish were enumerated by species, and fork length was recorded to the nearest mm. Total length was recorded and developmental stage was classified for juvenile lamprey. Length data was used to create length-frequency distributions by life stage for juvenile lamprey and summary statistics; including sample size, mean fork length, and minimum and maximum fork lengths for resident fishes. Lamprey data was submitted to CTUIR's lamprey restoration project for additional analyses and dissemination. 


\section{RESULTS AND DISCUSSION}

\section{Outmigration Monitoring}

Little change was observed in migration patterns of hatchery or natural salmonids compared with previous years. Migration patterns for hatchery salmonids are similar to those of natural salmonids, although the magnitude of smolt emigration can vary significantly (Figures 2-4). Median emigration for natural summer steelhead is roughly one week earlier than their hatchery counterparts. Median emigration of natural fall Chinook salmon is approximately one week later than hatchery conspecifics (Appendix Tables A1 to A3). Peaks in emigration for most hatchery migrants are observed shortly after release; however, coho salmon tend to have a protracted outmigration period.

Natural and hatchery summer steelhead exhibit similar trends in outmigration timing, but the cumulative distributions are statistically different (Figure 5; $D=0.2567, P=0.0085$ ). As would be expected, the temporal range of natural smolts is broader than that of hatchery; however, distributions are still different when adjusted for the volitional release date of hatchery smolts $(D$ $=0.2212, P=0.0087$ ). This is mostly due to the inherent sensitivity of the KolmogorovSmirnov Test, differences in means and variances and partially due to the natural smolt emigration already being in progress. In addition, a low number of hatchery steelhead were typically observed leaving the acclimation facilities prior to forced release (Grant et al. 2007). It took about 6 weeks for $90 \%$ of the hatchery smolts to emigrate from the system compared to 17 weeks for natural smolts ( 5 and 15 weeks for 50\%; respectively). The broad temporal range in the emigration timing of natural smolts may help buffer against the highly variable flow regime of the Umatilla River subbasin and provide a survival advantage when compared to hatchery smolts. In addition, patterns in the emigration timing of natural smolts may be linked to genetic variation in the out-migrating juveniles (Grant el al. 2007).

Annual correlations between migration timing and environmental factors have been species dependant and variable from year to year. We have observed associations between flow and temperature and migration timing of Chinook and coho salmon, but summer steelhead are not influenced by abiotic factors. The majority of anadromous fish movement is observed on the falling limb of the hydrograph (Figure 6). In addition, fish movement is affected by changes in daylight; diel patterns of movement are different between fish in-river and at canal facilities; and movement is influenced by canal operations (Figure 7).

Passage route selection at TMFD is influenced by canal diversion. Detection data suggests when West Extension Canal is diverting water, the majority of fish migrate past TMFD using the juvenile bypass. However, when the canal is not operating, juvenile fish passage is more prevalent through the east bank adult fish ladder (Figure 7). 


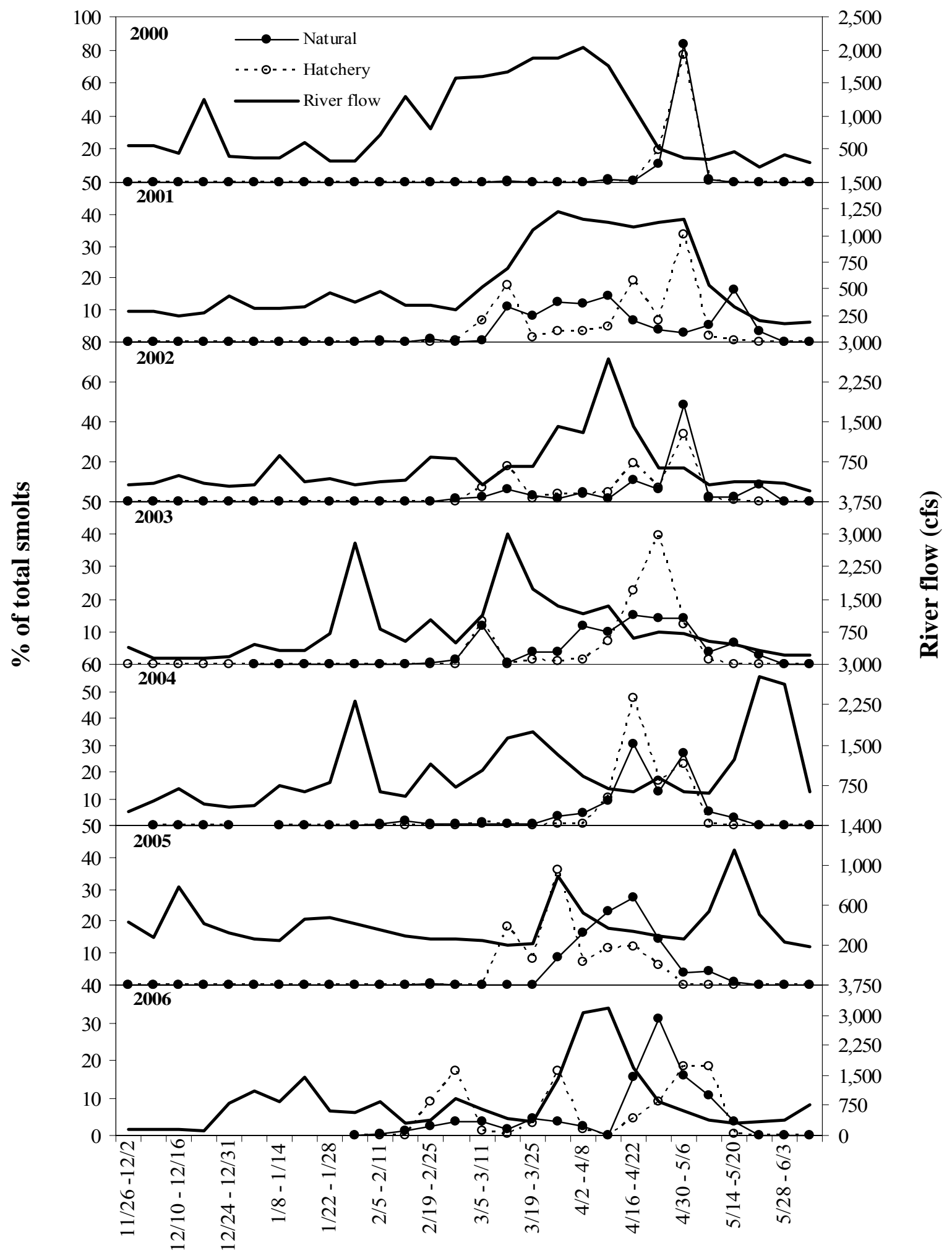

Week

Figure 2. Emigration timing for natural and hatchery spring Chinook salmon smolts in the Umatilla River, 2000-2006. 


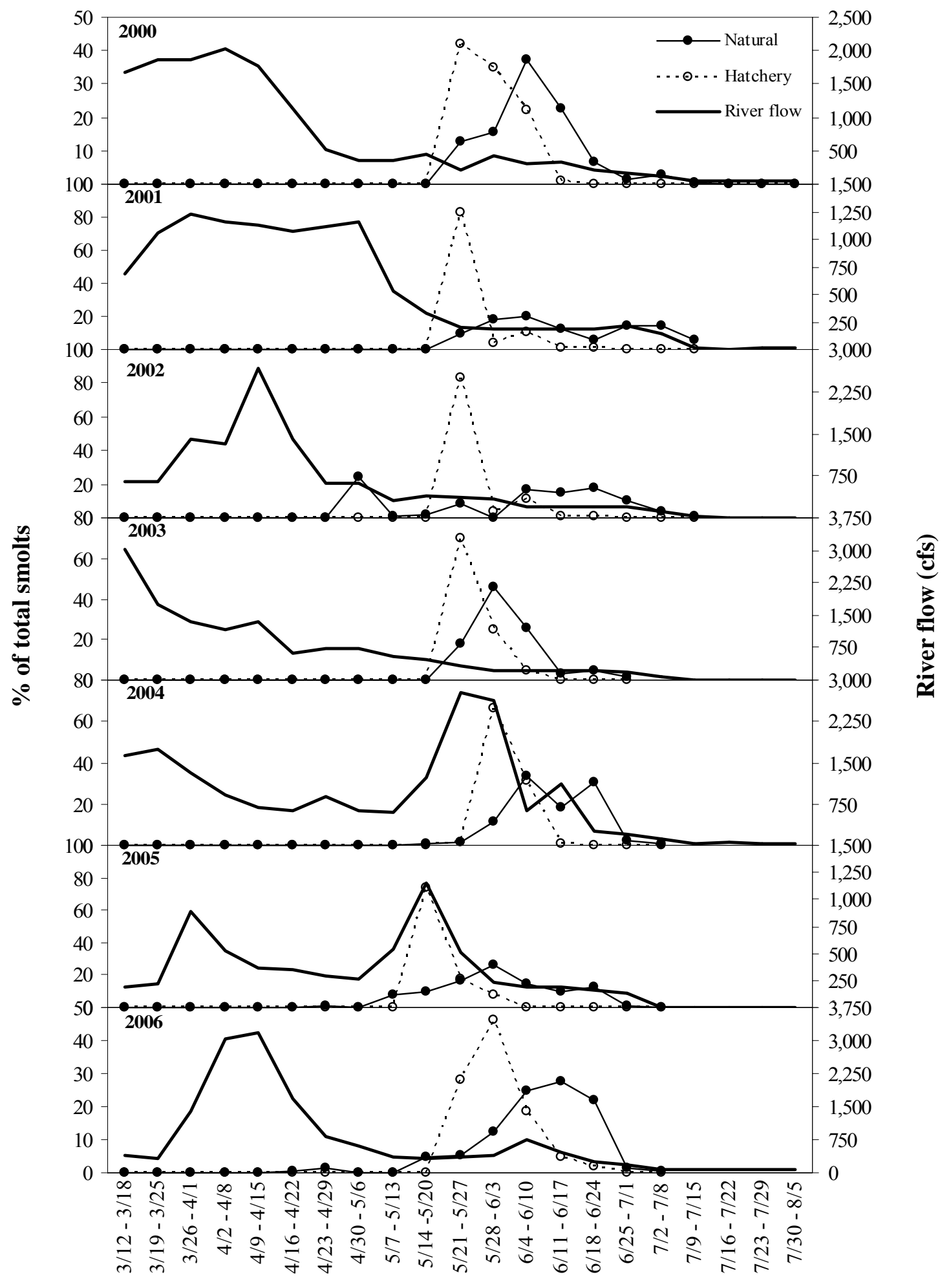

\section{Week}

Figure 3. Emigration timing for natural and hatchery subyearling fall Chinook salmon smolts in the Umatilla River, 2000-2006. 


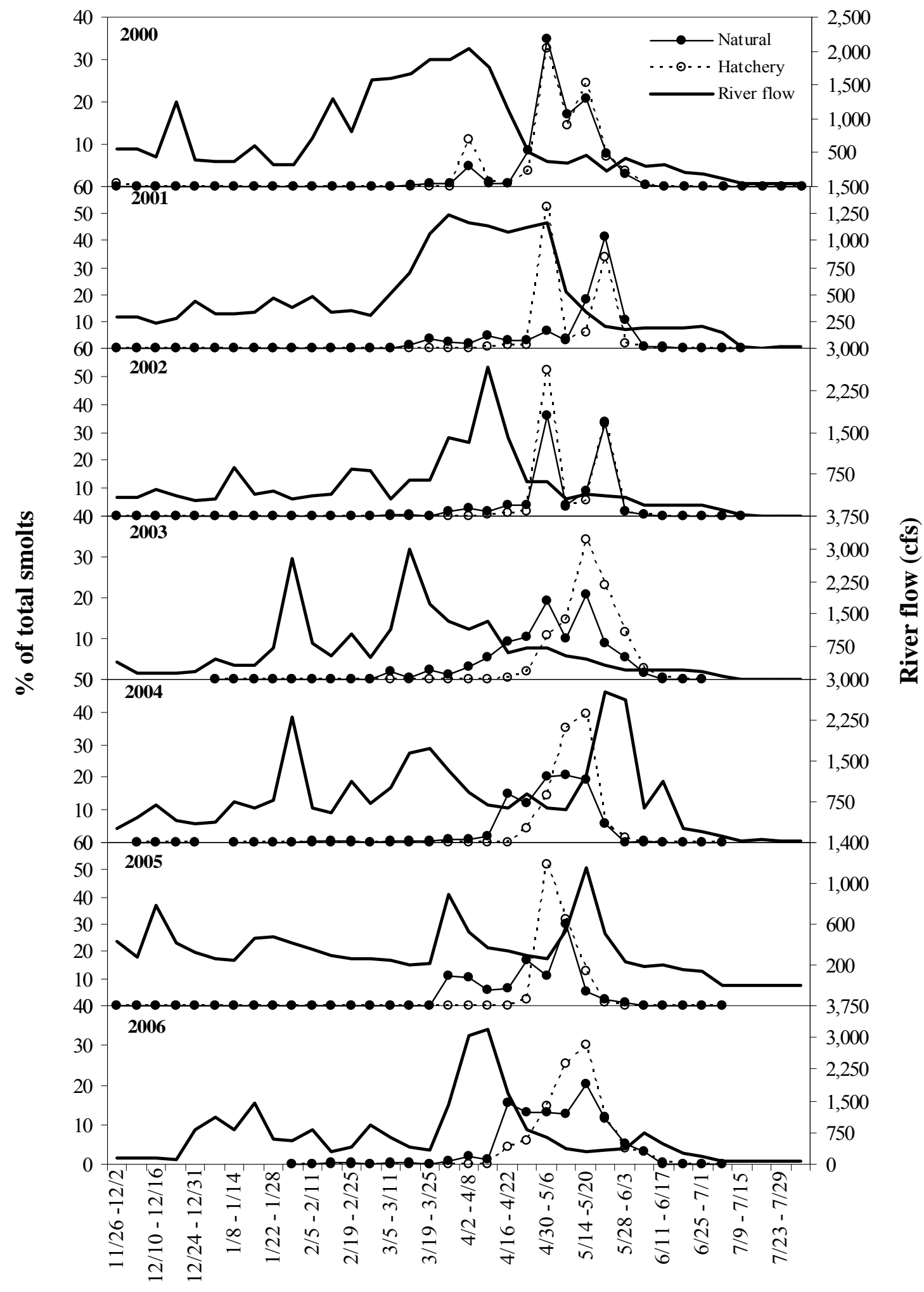

Week

Figure 4. Emigration timing for natural and hatchery summer steelhead smolts in the Umatilla River, 2000-2006. 


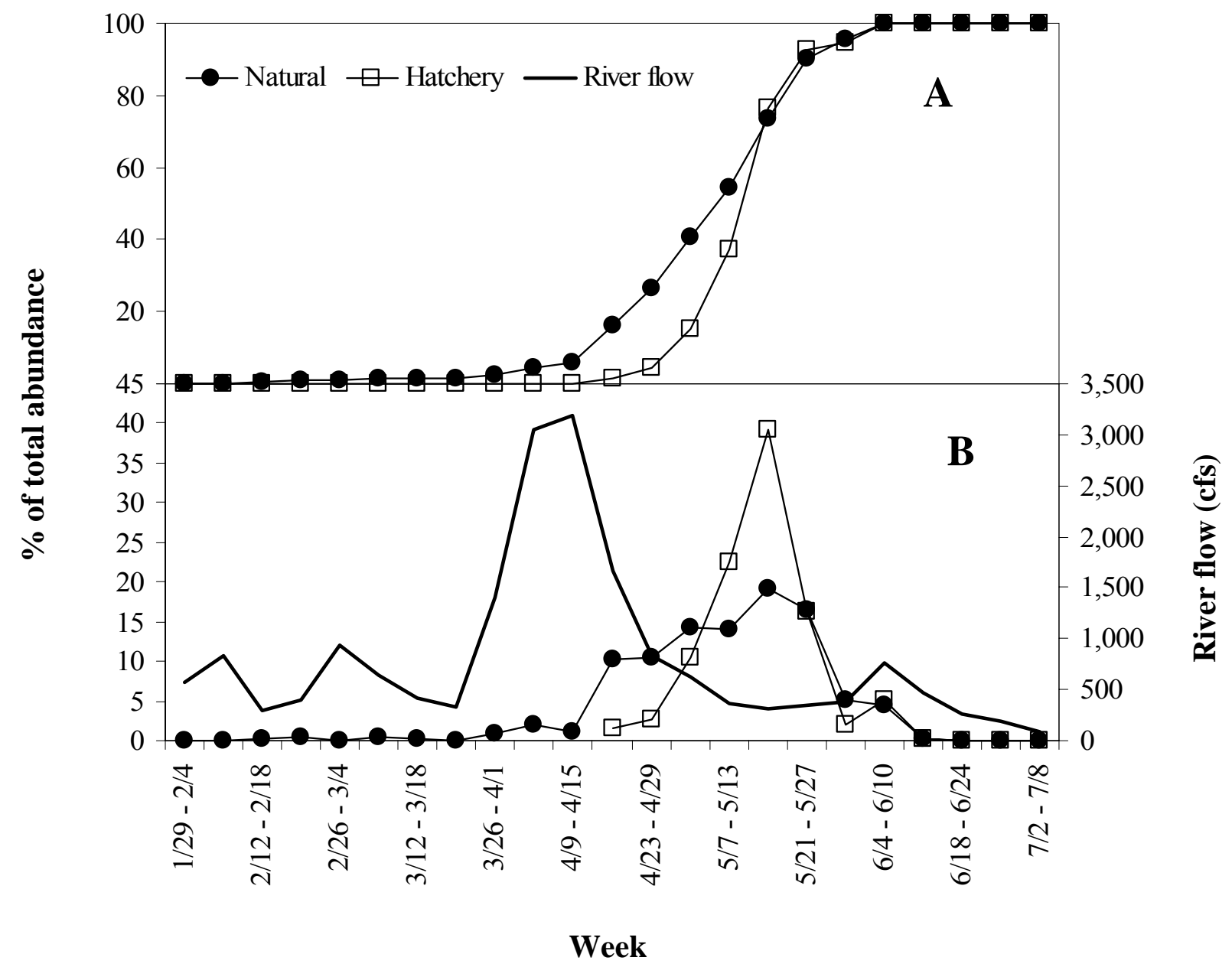

Figure 5. Cumulative (A) and percent abundance (B) of summer steelhead emigrating from the Umatilla River in 2006. 


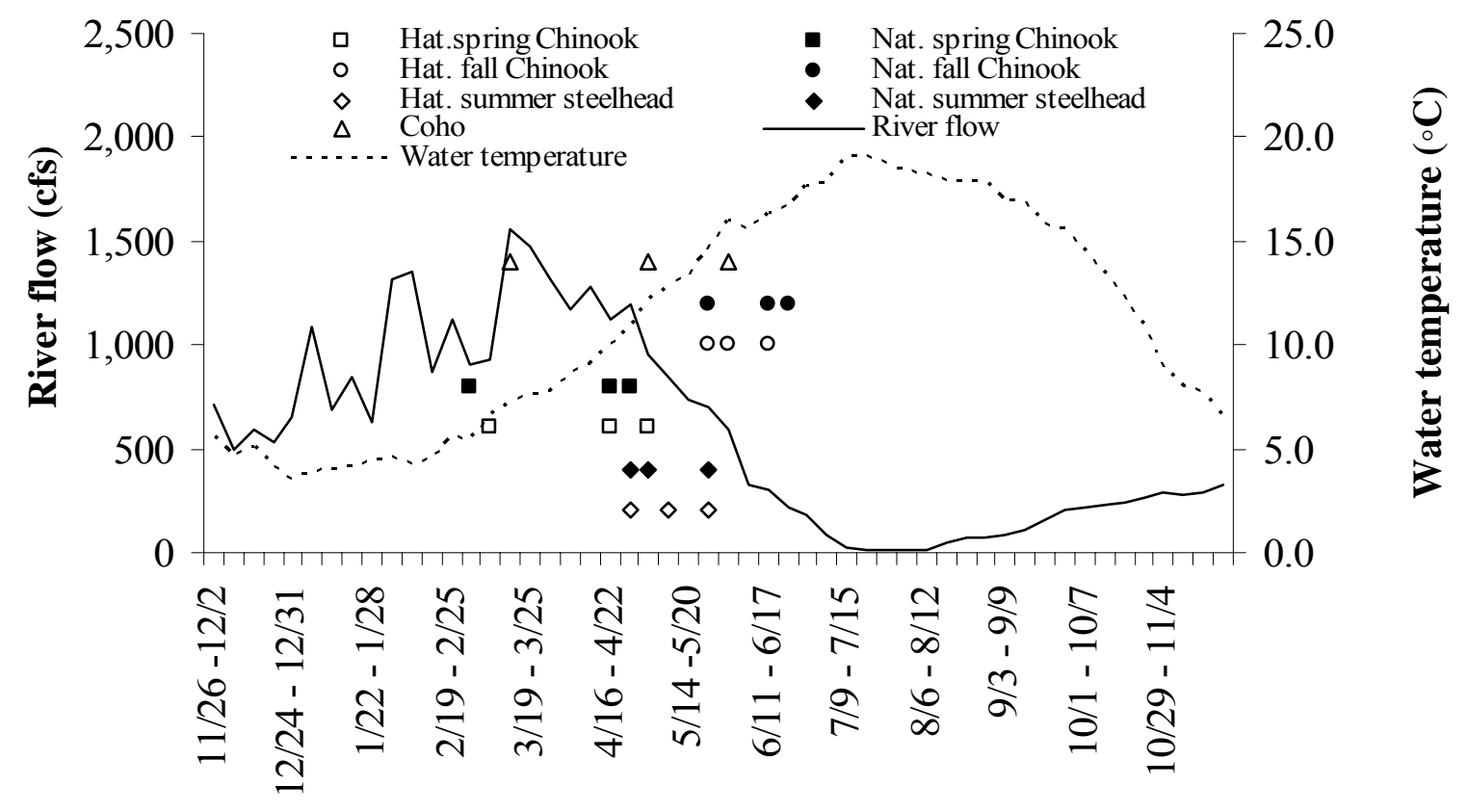

\section{Week}

Figure 6. Mean weekly flows and temperatures (1995-2006) measured in the Umatilla River compared to 10, 50, and 90\% emigration dates (left to right respectively) of Chinook salmon, coho salmon, and summer steelhead. Emigration timing distributions are the mean values calculated from outmigration years 1995-2006.

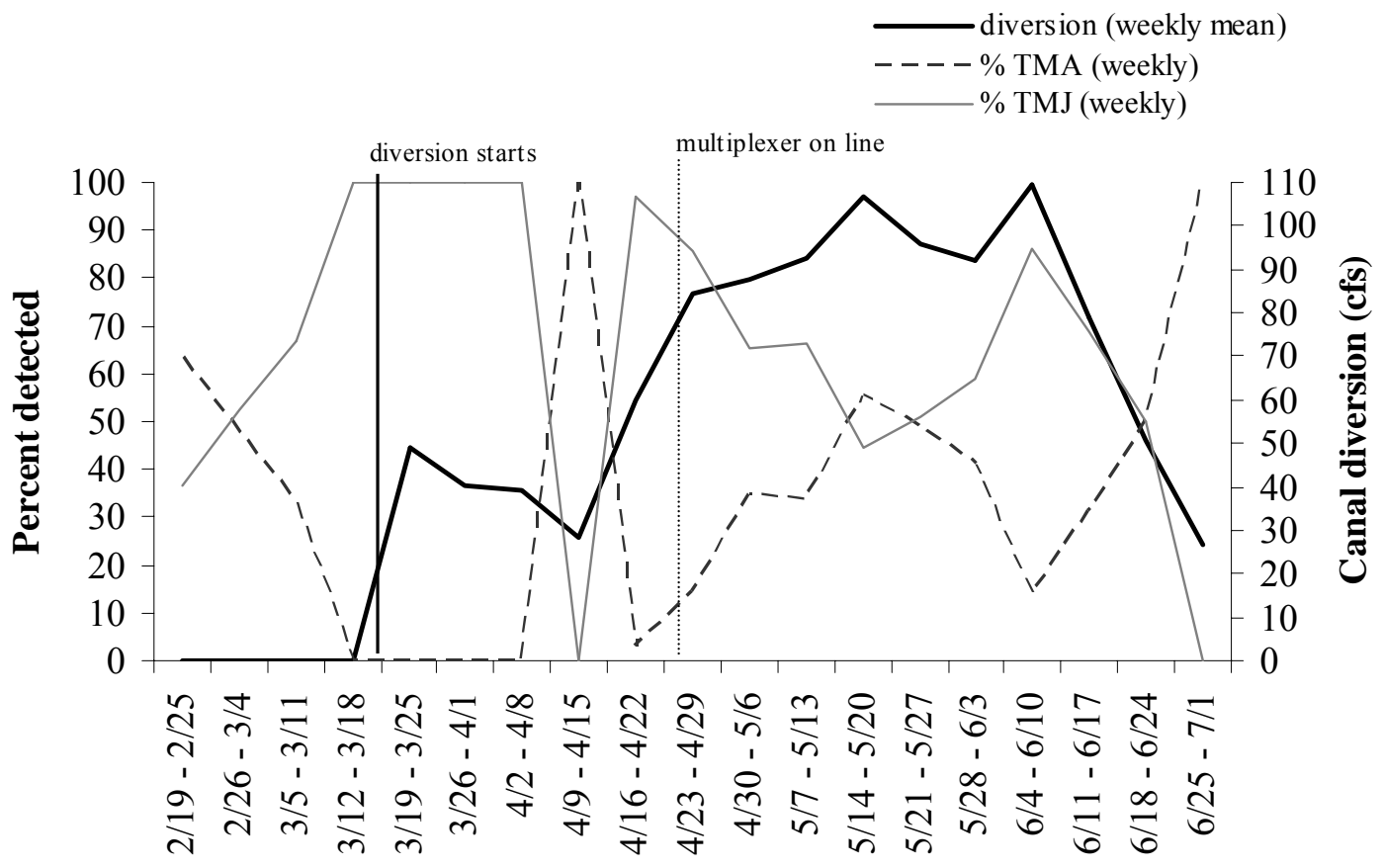

\section{Date}

Figure 7. Passage route selection at TMFD by PIT tagged production released salmonids associated with canal diversion at West Extension Canal. TMA is the east bank adult fish ladder and TMJ is the juvenile bypass. 
Size and age at emigration for Chinook salmon and summer steelhead in the Umatilla River is similar to that of surrounding subbasins (Contor editor 2003; Fast et al. 1991; Gallinat et al. 2003; Lindsay et al. 1986; Mayer and Schuck 2004; Peven et al. 1994). Spring Chinook salmon are emigrating as yearlings, fall Chinook salmon as subyearlings, and summer steelhead at a broad distribution of ages. One, two and three-year freshwater rearing accounts for $9.1 \%, 82.2 \%$ and $8.4 \%$ respectively of the life history of natural summer steelhead emigrating past TMFD (Tables 3 and 4). Both yearling and subyearling coho salmon have been observed emigrating from the Umatilla River.

Fish condition tends to deteriorate throughout the monitoring season as flows decrease and water temperature increases. In addition, hatchery fish typically exhibit higher rates of descaling compared to natural fish, which is likely due to fish acclimation activities, including transportation, netting, tagging, and seining during forced releases. Bird marks are observed at a higher rate for hatchery summer steelhead compared to other species/origin type (Tables 5). This is possibly a result of size-dependant selection by avian predators (Collis et al. 2001). Neascus sp. (black spot) infestation is prevalent in natural spring Chinook salmon and summer steelhead migrants (Table 5). Mortality rates tended to be higher for natural compared to hatchery-reared fish (Table 6).

Efficiency of the juvenile bypass is influenced by water temperature, river flow and canal diversion rate; relationships are species-specific and variable from year to year. Natural spring Chinook salmon exhibit the strongest relationship with canal diversion rate (Figure 8), while summer steelhead exhibit the weakest. Trap efficiencies are slightly lower for hatchery summer steelhead, coho salmon, and natural fall Chinook salmon compared to all other species (Table 7; Appendix Table A-4). In addition, efficiency estimates are more variable for Chinook salmon compared to coho salmon and summer steelhead. Termination of canal diversion with the onset of Phase I pump exchange briefly diminishes bypass efficiency.

Paired release tests in 2004 and 2005 indicated temporal and spatial variability in the recapture rate and travel speed of hatchery Chinook salmon (Figure 9 and 10). Recapture rates were considerably lower with greater variability and travel speed faster for fish released upstream of the juvenile facility compared to those released within the facility. Prior trap exposure had little or no effect on recapture rate or travel speed.

Patterns in fish movement were primarily a result of seasonal patterns in river conditions, canal operations, the level of smoltification and behavioral responses to hydraulic heterogeneity associated with TMFD and its fish passage routes. Similar trends in entrainment rate have been observed at Chandler Fish Facility (Sandford and Ruehle 1996) and corresponding patterns between migration and smoltification were observed by Beckman et. al. (2000) for spring Chinook salmon in the Yakima River. In addition, laboratory tests by Kemp et. al. (2005) determined that Pacific salmonid smolts more readily pass through an open channel compared to a constricted channel and believed this to be a result of rapidly accelerating flow. They suggest that fine-scale behavior of smolts as a result of local hydraulic conditions may help explain lower-than expected entrainment rates for fish passage facilities. 
Table 3. Natural summer steelhead smolt size and age upon emigration from the Umatilla River, 1995-2006.

\begin{tabular}{|c|c|c|c|c|c|c|c|c|c|c|}
\hline \multicolumn{3}{|c|}{ Outmigration Mean fork length } & \multicolumn{4}{|c|}{ Fork length $(\mathrm{mm})$ by freshwater age class } & \multicolumn{4}{|c|}{ Percent of freshwater age class ${ }^{b}$} \\
\hline year & $(\mathrm{mm})(\mathrm{SD})$ & Sample size ${ }^{\mathrm{a}}$ & $1(\mathrm{SD})$ & $2(\mathrm{SD})$ & $3(\mathrm{SD})$ & $4(\mathrm{SD})$ & 1 & 2 & 3 & 4 \\
\hline 1995 & $175(28)$ & 1,612 & -- & -- & -- & -- & -- & -- & -- & -- \\
\hline 1996 & $176(24)$ & 2,970 & -- & -- & -- & -- & -- & -- & -- & -- \\
\hline 1997 & $157(23)$ & 183 & -- & -- & -- & -- & -- & -- & -- & -- \\
\hline 1998 & $186(33)$ & 2,547 & -- & -- & -- & -- & -- & -- & -- & -- \\
\hline 1999 & $181(22)$ & 1,704 & -- & -- & -- & -- & -- & -- & -- & -- \\
\hline 2000 & $180(26)$ & 619 & -- & -- & -- & -- & -- & -- & -- & -- \\
\hline 2001 & $178(28)$ & 844 & -- & -- & -- & -- & -- & -- & -- & -- \\
\hline 2002 & $166(30)$ & 571 & -- & -- & -- & -- & -- & -- & -- & -- \\
\hline 2003 & $176(30)$ & 959 & $102(6)$ & $170(27)$ & $211(42)$ & $270(53)$ & 3.4 & 79.6 & 16.0 & 1.0 \\
\hline 2004 & $167(30)$ & 655 & $104(16)$ & $165(25)$ & $292(32)$ & $202(--)$ & 5.9 & 82.6 & 11.3 & 0.2 \\
\hline 2005 & $179(25)$ & 1,511 & $160(28)$ & $185(27)$ & $210(44)$ & -- & 7.5 & 88.1 & 4.4 & 0.0 \\
\hline 2006 & $179(26)$ & 1,005 & $164(31)$ & $184(28)$ & $191(23)$ & -- & 17.6 & 77.4 & 5.0 & 0.0 \\
\hline Average & $178(28)$ & 15,180 & $150(37)$ & $177(28)$ & $202(37)$ & $256(55)$ & 9.1 & 82.2 & 8.4 & 0.2 \\
\hline
\end{tabular}

a Sample sizes for age/length analysis from 2003 to 2006 were 382, 477, 589 and 563; respectively.

b Derived from scale analysis of smolts trapped at TMFD. 
Table 4. Natural Chinook salmon smolt size upon emigration from the Umatilla River, 19952006.

\begin{tabular}{|c|c|c|c|c|}
\hline \multicolumn{3}{|c|}{ Spring Chinook } & \multicolumn{2}{|c|}{ Fall Chinook } \\
\hline $\begin{array}{l}\text { Outmigration } \\
\text { year }\end{array}$ & $\begin{array}{l}\text { Mean fork length } \\
(\mathrm{mm})(\mathrm{SD})\end{array}$ & Sample size & $\begin{array}{l}\text { Mean fork length } \\
\quad(\mathrm{mm})(\mathrm{SD})\end{array}$ & Sample size \\
\hline 1995 & $109(19)$ & 561 & $73(12)$ & 395 \\
\hline 1996 & $105(14)$ & 160 & $61(9)$ & 9 \\
\hline 1997 & $99(10)$ & 14 & $64(8)$ & 21 \\
\hline 1998 & $108(14)$ & 1,033 & $73(11)$ & 5,050 \\
\hline 1999 & $103(9)$ & 616 & $87(12)$ & 24 \\
\hline 2000 & $106(15)$ & 82 & $77(14)$ & 2,385 \\
\hline 2001 & $103(7)$ & 125 & $74(12)$ & 1,336 \\
\hline 2002 & $101(14)$ & 861 & $74(11)$ & 723 \\
\hline 2003 & $100(10)$ & 545 & $78(9)$ & 787 \\
\hline 2004 & $103(9)$ & 350 & $72(11)$ & 1,054 \\
\hline 2005 & $112(10)$ & 596 & $75(13)$ & 2,723 \\
\hline 2006 & $105(9)$ & 443 & $91(10)$ & 618 \\
\hline Average & $105(13)$ & 5,379 & $75(13)$ & 15,130 \\
\hline
\end{tabular}


Table 5. Condition summary for hatchery and natural smolts sampled at TMFD, 2004-2006.

\begin{tabular}{|c|c|c|c|c|c|c|c|c|}
\hline \multirow[b]{2}{*}{$\begin{array}{l}\text { Outmigration } \\
\text { year }\end{array}$} & \multicolumn{4}{|c|}{ Hatchery } & \multicolumn{4}{|c|}{ Natural } \\
\hline & $\begin{array}{c}\text { No. } \\
\text { examined }\end{array}$ & $\%$ bird & $\%$ injury & $\%$ parasite & No. examined & $\%$ bird & $\%$ injury & $\%$ parasite \\
\hline \multicolumn{9}{|c|}{ Spring Chinook } \\
\hline 2004 & 2,355 & 1.2 & 2.9 & 0.8 & 349 & 0.9 & 2.6 & 44.7 \\
\hline 2005 & 1,313 & 1.9 & 1.1 & 0.0 & 588 & 0.5 & 0.7 & 27.9 \\
\hline 2006 & 1,383 & 2.5 & 1.7 & 0.1 & 443 & 0.5 & 0.7 & 27.1 \\
\hline \multicolumn{9}{|c|}{ Fall Chinook yearlings } \\
\hline 2004 & 3,188 & 1.7 & 2.9 & 0.8 & -- & -- & -- & -- \\
\hline 2005 & 1,696 & 2.4 & 1.7 & 0.2 & -- & -- & -- & -- \\
\hline 2006 & 1,341 & 1.4 & 0.7 & 0.6 & -- & -- & -- & -- \\
\hline \multicolumn{9}{|c|}{ Fall Chinook subyearlings } \\
\hline 2004 & 1,604 & 0.3 & 1.5 & 0.1 & 1,035 & 0.1 & 2.5 & 0.0 \\
\hline 2005 & 1,065 & 0.4 & 1.2 & 0.0 & 2,668 & 0.2 & 1.9 & 0.9 \\
\hline 2006 & 738 & 0.3 & 0.7 & 0.1 & 617 & 0.0 & 0.6 & 0.2 \\
\hline \multicolumn{9}{|c|}{ Coho ${ }^{\mathrm{a}}$} \\
\hline 2004 & 149 & 2.0 & 9.4 & 0.7 & 2,474 & 1.5 & 4.4 & 1.1 \\
\hline 2005 & 366 & 1.6 & 0.5 & 0.3 & 2,184 & 1.4 & 1.6 & 0.3 \\
\hline 2006 & 103 & 1.0 & 1.9 & 1.0 & 907 & 2.0 & 1.5 & 1.7 \\
\hline \multicolumn{9}{|c|}{ Summer steelhead } \\
\hline 2004 & 510 & 3.1 & 3.9 & 0.2 & 657 & 0.9 & 4.3 & 19.3 \\
\hline 2005 & 482 & 6.2 & 3.9 & 0.0 & 1,498 & 2.5 & 2.1 & 10.0 \\
\hline 2006 & 610 & 3.9 & 1.5 & 0.8 & 1,003 & 1.1 & 2.4 & 17.4 \\
\hline
\end{tabular}

${ }^{\mathrm{a}}$ Includes natural and unmarked hatchery fish. 
Table 6. Unknown source and sampling mortality for hatchery and natural smolts sampled at TMFD, 2004-2006.

\begin{tabular}{lccccc}
\hline \multirow{2}{*}{$\begin{array}{c}\text { Outmigration } \\
\text { year }\end{array}$} & \multicolumn{2}{c}{ Hatchery } & \multicolumn{2}{c}{ Natural } \\
\cline { 2 - 3 } 2004 & No. sampled & \% mortality & & No. sampled & \% mortality \\
2005 & 6,278 & Spring Chinook \\
2006 & 16,481 & 0.2 & & 351 & 0.3 \\
& 12,317 & 0.1 & & 606 & 1.0 \\
\end{tabular}

$\begin{array}{lcccc}2004 & 10,532 & 0.7 & -- & -- \\ 2005 & 9,958 & 0.3 & -- & -- \\ 2006 & 9,654 & 0.2 & -- & --\end{array}$

\begin{tabular}{|c|c|c|c|c|}
\hline \\
\hline 2004 & 5,297 & 0.9 & 2,206 & 2.3 \\
\hline 2005 & 6,825 & 0.3 & 9,488 & 0.9 \\
\hline 2006 & 9,864 & 0.3 & 1,159 & 1.7 \\
\hline \multicolumn{5}{|c|}{$\mathrm{Coho}^{\mathrm{a}}$} \\
\hline 2004 & 266 & 0.4 & 5,563 & 0.4 \\
\hline 2005 & 682 & 0.1 & 13,371 & 1.6 \\
\hline 2006 & 446 & 0.2 & 7,799 & 0.2 \\
\hline \multicolumn{5}{|c|}{ Summer steelhead } \\
\hline 2004 & 1071 & 0.3 & 660 & 0.9 \\
\hline 2005 & 2197 & 4.7 & 1,992 & 0.5 \\
\hline 2006 & 1,720 & 0.5 & 1,020 & 1.8 \\
\hline
\end{tabular}




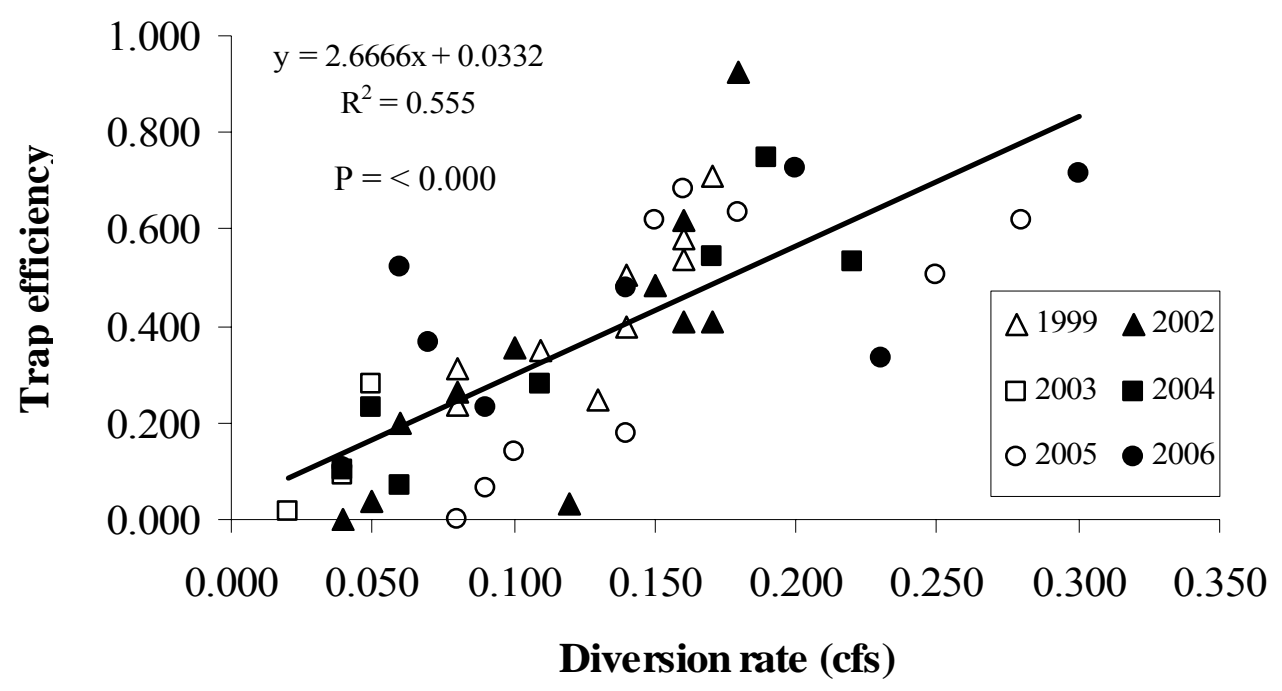

Figure 8. Relationship between canal diversion rate and efficiency of the juvenile bypass/trapping facility. Efficiency estimates used are from natural spring Chinook salmon.

Table 7. Species-specific mean efficiency estimates for the juvenile bypass/trapping facility at West Extension Canal, 1999-2006.

\begin{tabular}{lcc}
\hline Species & No. of releases & Trap efficiency (SD) \\
\hline Hatchery Chinook $(1+)$ & 129 & $0.30(0.21)$ \\
Hatchery fall Chinook $(0+)$ & 70 & $0.34(0.22)$ \\
Hatchery summer steelhead & 77 & $0.22(0.12)$ \\
Coho & 62 & $0.26(0.14)$ \\
Natural spring Chinook & 47 & $0.37(0.24)$ \\
Natural fall Chinook & 27 & $0.21(0.18)$ \\
Natural summer steelhead & 73 & $0.32(0.12)$ \\
Total/average & & $0.29(0.19)$ \\
\hline
\end{tabular}




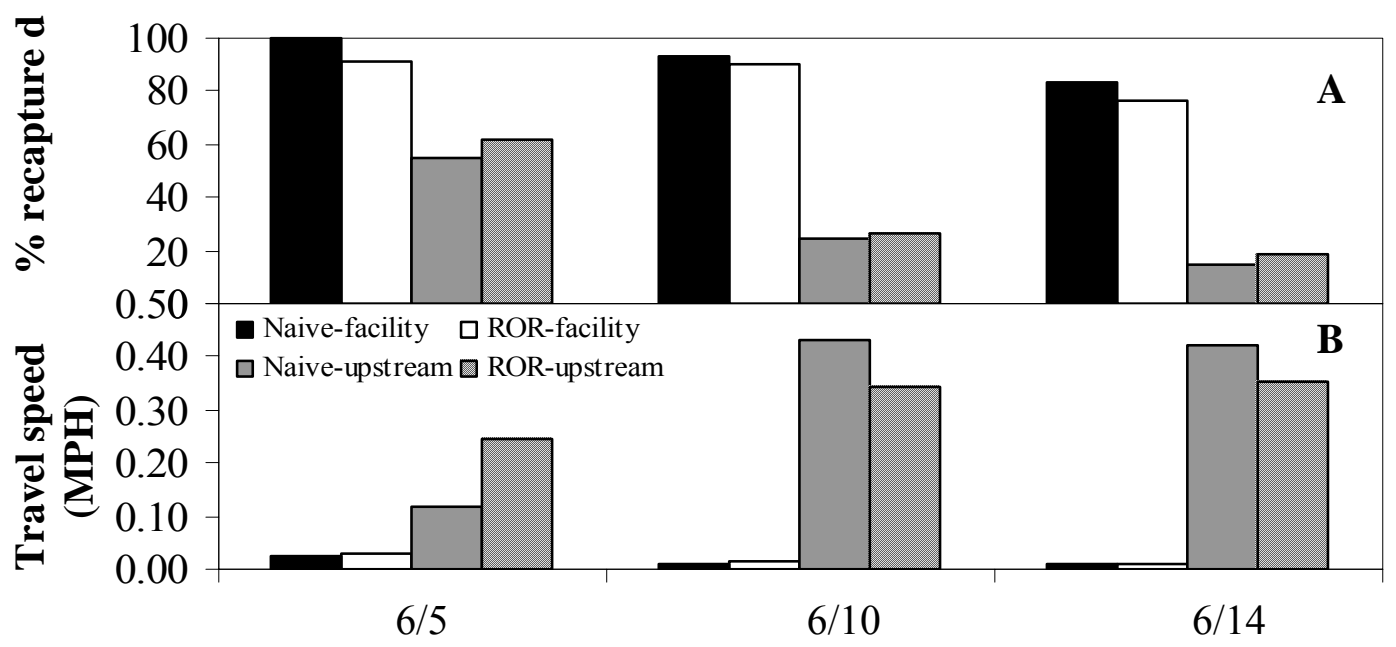

Figure 9. Recapture rate (A) and travel speed (B) for hatchery subyearling fall Chinook salmon released in 2004.

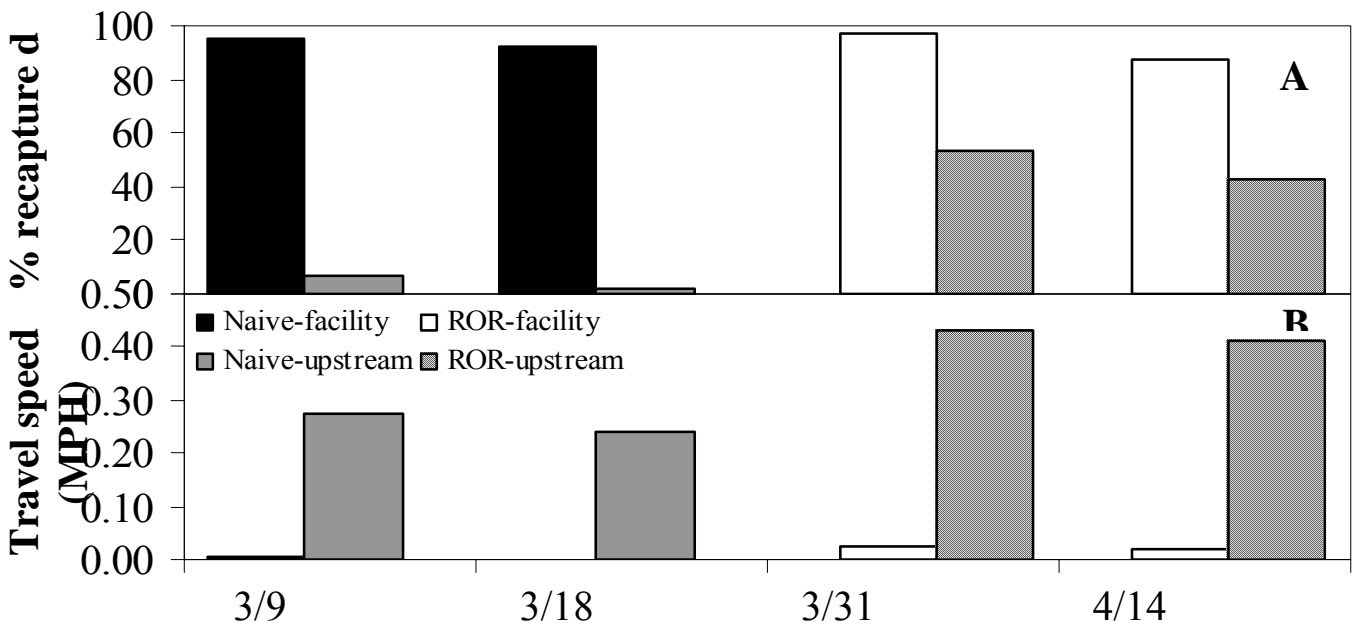

Figure 10. Recapture rate (A) and travel speed (B) for hatchery spring Chinook salmon released in 2005. 


\section{Abundance and Survival:}

Abundance estimates for naturally-produced Chinook salmon and summer steelhead smolts are presented in Table 8. Abundance of summer steelhead has fluctuated since 1995, however trends reflect little or no change in productivity. The average annual smolt production is $50,217(+/-$ 6,116). Smolt yield for spring Chinook salmon has ranged between 603 and 52,645 over the past 11 years. Estimates for the 2004-2006 period are below the 11 year mean (Table 8). Production of fall Chinook smolts has fluctuated dramatically over the same time frame; smolt estimates have ranged between 169 to 242,100 from 1995-2006. A suite of factors including spawning escapement, quality and quantity of rearing habitat, river flow and overwinter survival are likely contributing to the highly variable smolt production. In 2005, a stable flow regime combined with a late season freshet likely played a key role in the strong overwinter survival and outmigration success of fall Chinook in the lower river (Figure 11). In contrast, dramatic flow fluctuations combined with a high magnitude spring freshet may have contributed to the lower abundance of Chinook emigrants in 2006.

Table 8. Abundance estimates of natural Chinook salmon and steelhead smolts emigrating from the Umatilla River, 1995-2006.

\begin{tabular}{lccc}
\hline & \multicolumn{3}{c}{ Species } \\
\cline { 2 - 4 } Outmigration & & & \\
\cline { 2 - 4 } 1995 & Summer steelhead & Spring Chinook & Fall Chinook \\
1996 & 54,361 & 19,900 & 6,912 \\
1997 & 73,361 & 1,885 & 169 \\
1998 & 22,221 & 603 & 830 \\
1999 & 59,182 & 13,045 & 242,100 \\
2000 & 46,530 & 23,809 & 1,292 \\
2001 & 81,759 & 9,051 & 32,542 \\
2002 & 33,844 & 4,746 & 28,597 \\
2003 & 77,016 & 35,033 & 9,812 \\
2004 & 24,773 & 52,645 & 30,998 \\
2005 & 35,640 & 14,159 & 27,789 \\
2006 & 59,807 & 13,137 & 107,858 \\
& 34,110 & 8,458 & 12,781 \\
Average & & & 41,807 \\
\hline
\end{tabular}

Smolt-per-spawner ratios for Umatilla salmon and summer steelhead are considerably lower than that of surrounding subbasins (Berg and Fast 2002; Gallinat and Ross 2006). The average number of smolts produced per spawner for brood years 1993-2004 was 27.1 natural spring Chinook salmon, 75.8 fall Chinook salmon and 26.6 summer steelhead (Figure 12). 


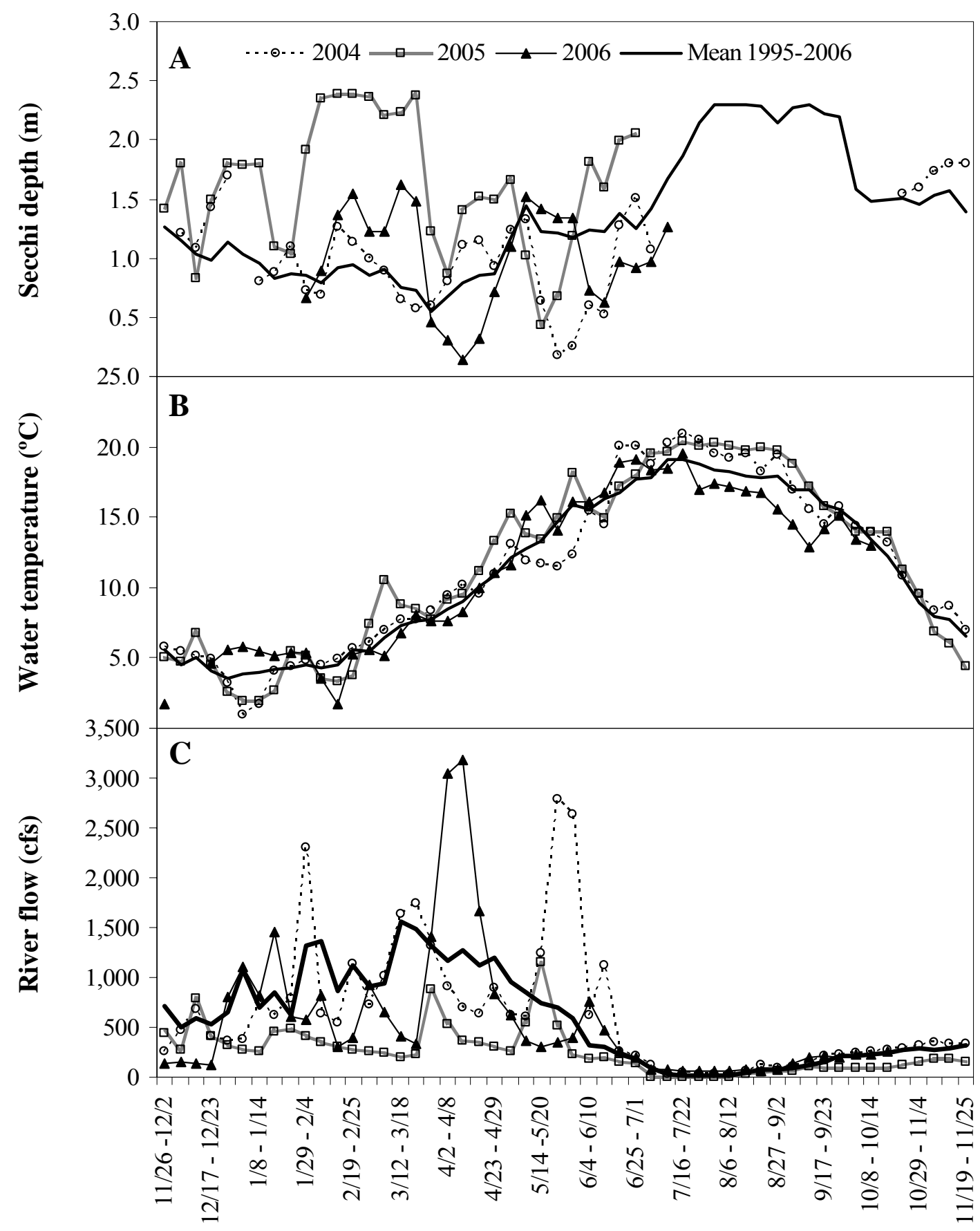

Week

Figure 11. Weekly secchi depth (A), water temperature (B), and river flow (C), Umatilla River, 2004 - 2006. 


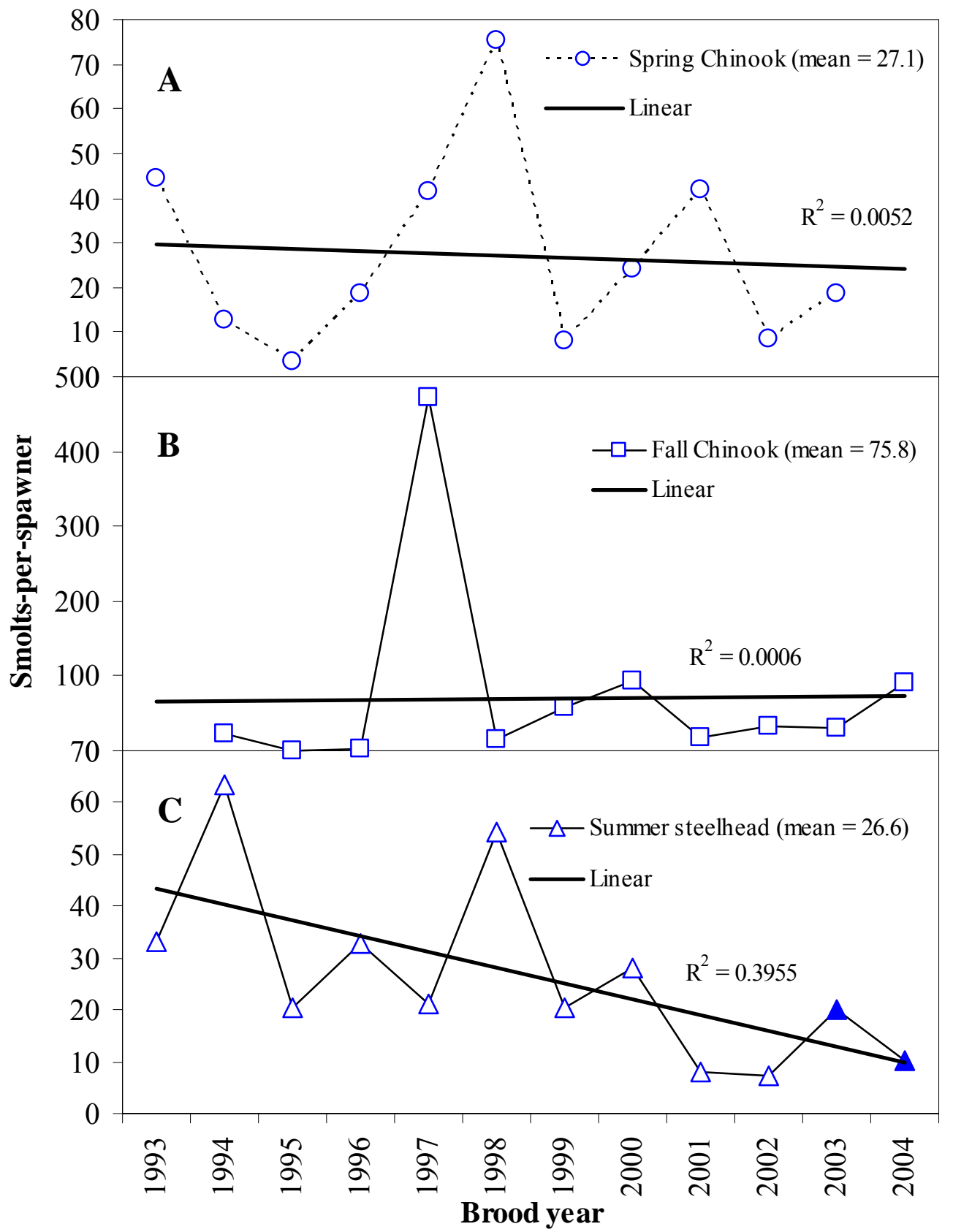

Figure 12. Smolt-per-spawner estimates of natural (A) spring Chinook salmon, (B) fall Chinook salmon and (C) summer steelhead in the Umatilla River, BY1993-2004. Adjusted for freshwater age structure. $\boldsymbol{\Delta}$ indicates dataset incomplete for age $3+$ and $4+$ smolts. 
Summer steelhead smolts-per-spawner plotted against total spawning escapement indicated a declining smolt output with increasing escapement (Figure 13). Smolt estimates for natural summer steelhead between smolt outmigration year (SOY) 1995-2006 were reasonably strong, suggesting other in-basin rearing and migration conditions may be limiting the smolt production. Contor (2003) suggested flows in summer rearing habitat may be a limiting factor for Umatilla summer steelhead. Additional reports by Contor et al (1997) linked annual winter/spring flows with adult returns two years later. This suggests flow impacts freshwater survival across multiple life stages and age classes.

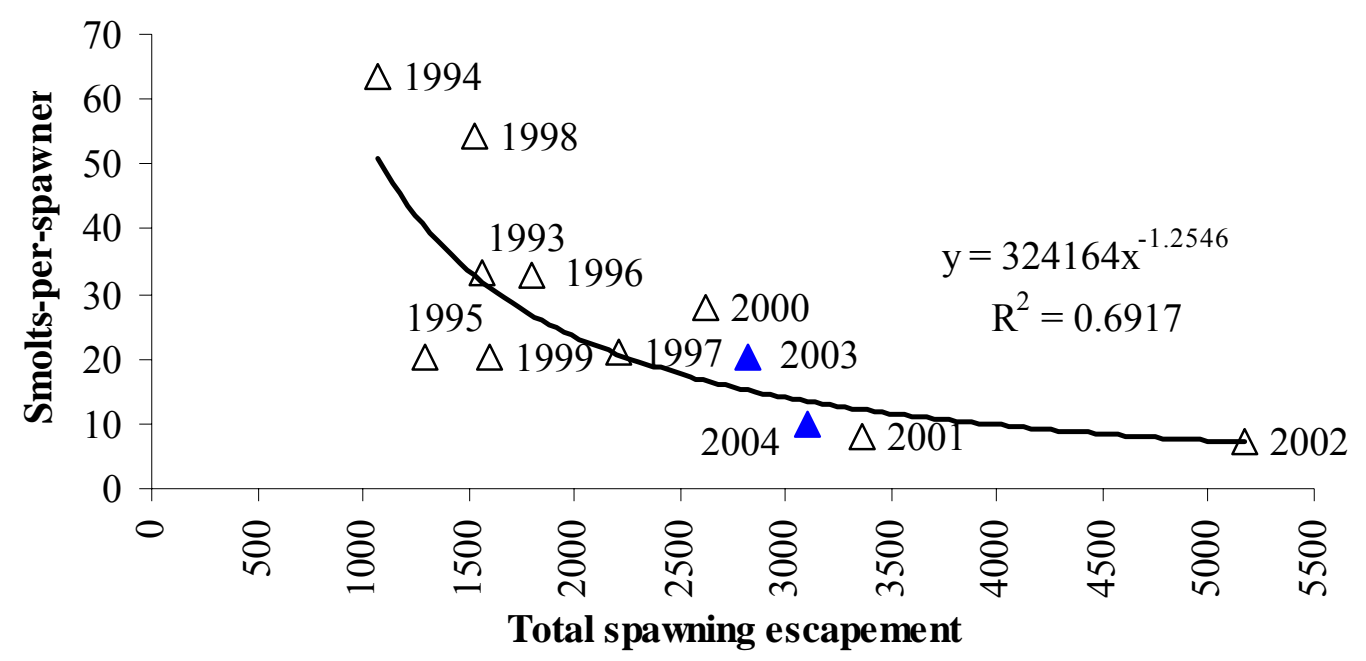

Figure 13. Relationship between total spawning escapement and smolts produced per spawner for natural summer steelhead between brood years 1993-2004. $\boldsymbol{\Delta}$ indicates return data incomplete.

The average number of summer steelhead smolts-produced-per-female between BY's 1993-2004 was 40.0 (Figure 14). Egg-to-smolt survival rates for natural summer steelhead ranged between $0.21-1.58 \%$ for BY 1993-2004, with a mean of $0.77 \%$ (Figure 15; Appendix Table A-5). Smoltto-adult return (SAR) rates for naturally-reared summer steelhead were within the range of nearby subbasins. The mean SAR rate for Umatilla summer steelhead between SOY 1995-2002 was 3.53\% (Figure 16; Appendix Table A-6). Preliminary estimates for the Yakima River (smolts at Prosser Dam to adults at McNary Dam) averaged 5.12\% for SOY 2002-2003 (D. Lind. pers. comm.). SAR estimates for the John Day River subbasin averaged 1.65\% between 20012004 (W. Wilson. pers. comm.).

Survival estimates for natural smolts are limited, however data suggests out-of-basin survival from TMFD to JDD is higher than in-basin survival to TMFD for most species. In-basin survival to TMFD averaged $44 \%, 46 \%$ and $34 \%$ for naturally-produced spring Chinook salmon, coho salmon and summer steelhead, respectively, from 1999-2001 (Table 9). Out-of-basin estimates have ranged from $16 \%$ in fall Chinook salmon to $65 \%$ in naturally-reared spring Chinook salmon over the 1999-2006 period. 


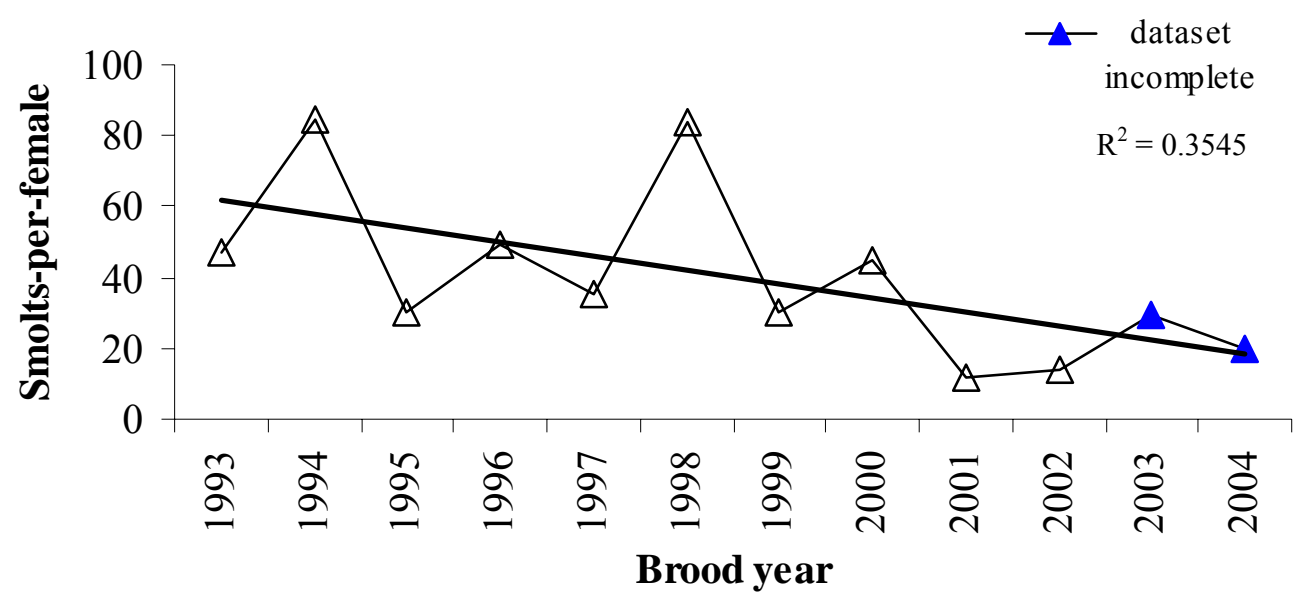

Figure 14. Natural summer steelhead smolts-per-female by brood year, 1993-2004.

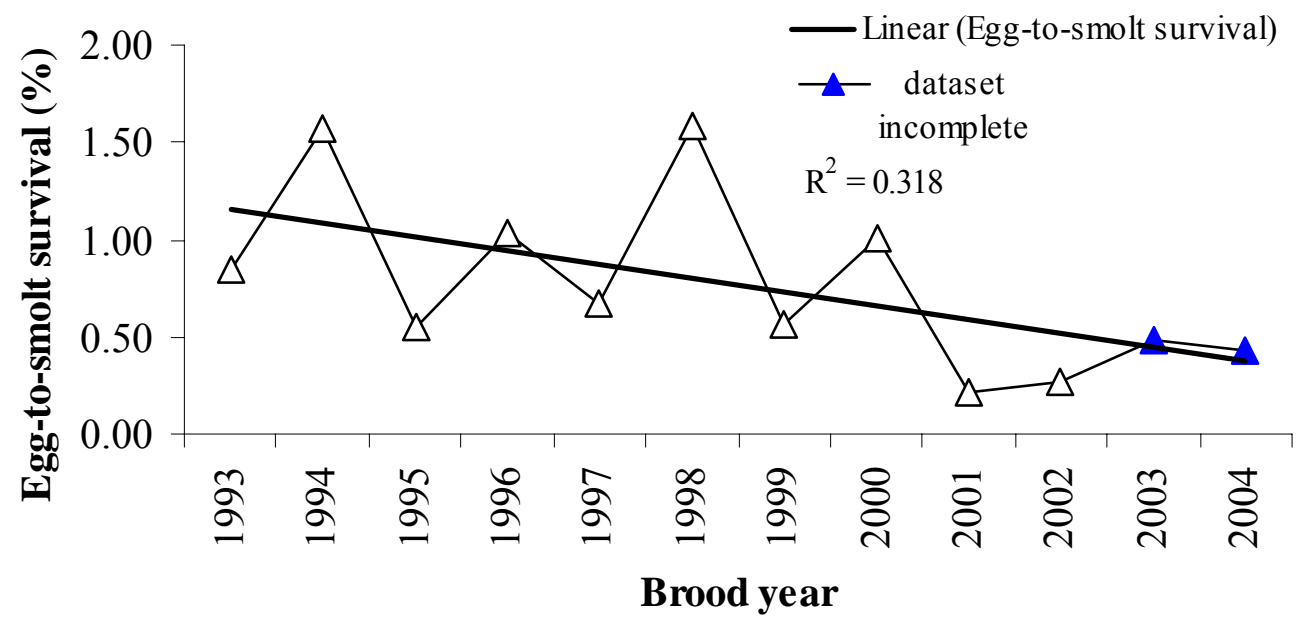

Figure 15. Natural summer steelhead egg-to-smolt survival by brood year, 1993-2004.

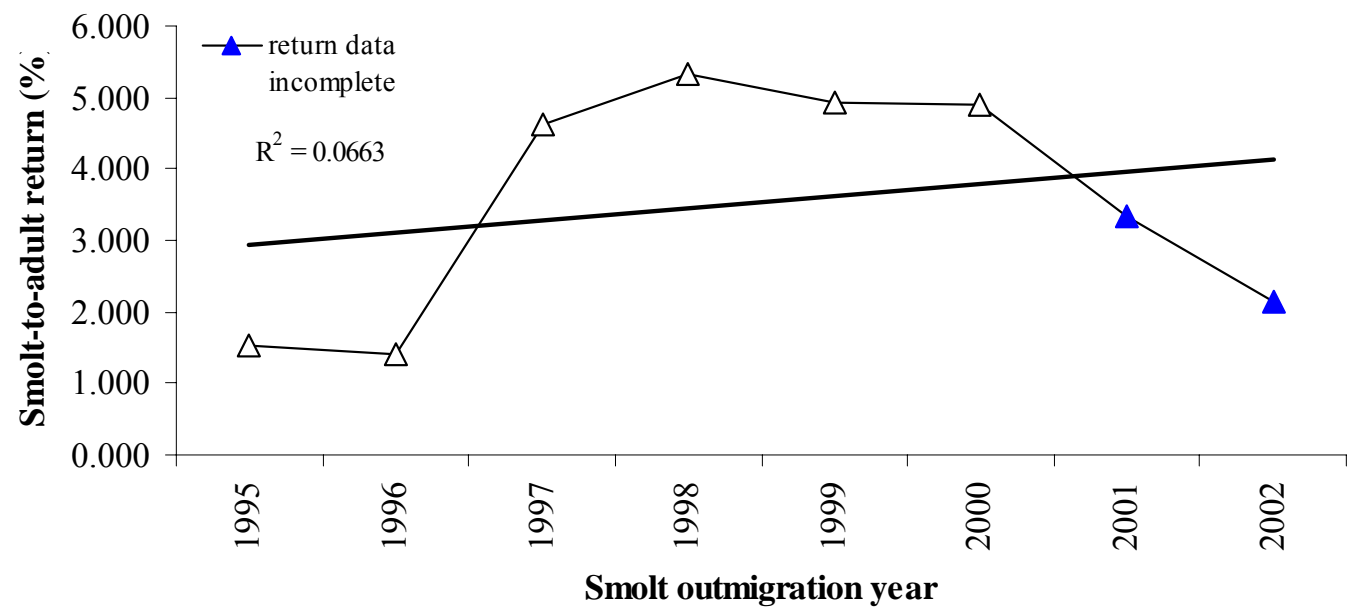

Figure 16. Natural summer steelhead smolt-to-adult return (\%) by smolt outmigration year, 1995-2002. 
Table 9. In- and out-of-basin survival estimates for juvenile natural salmon and steelhead emigrating from the Umatilla River, 1999-2006. Standard errors are in parentheses.

\begin{tabular}{|c|c|c|c|c|c|c|c|c|}
\hline \multirow{4}{*}{$\begin{array}{l}\text { Outmigration } \\
\text { year }^{\mathrm{a}}\end{array}$} & \multicolumn{8}{|c|}{ Species } \\
\hline & \multicolumn{2}{|c|}{ Spring Chinook salmon } & \multicolumn{2}{|c|}{ Fall Chinook salmon } & \multicolumn{2}{|c|}{ Coho salmon } & \multicolumn{2}{|c|}{ Summer steelhead } \\
\hline & Release to & TMFD to & Release to & TMFD to & Release to & TMFD to & Release to & TMFD to \\
\hline & TMFD & JDD & TMFD & JDD & TMFD & JDD & TMFD & JDD \\
\hline 1999 & $0.41(0.07)$ & $0.74(0.12)$ & (b) & (b) & (b) & (b) & $0.26(0.02)$ & $0.69(0.07)$ \\
\hline 2000 & (b) & (b) & (b) & (b) & $0.46(0.22)$ & (b) & $0.37(0.04)$ & $0.57(0.14)$ \\
\hline 2001 & $0.47(0.08)$ & $0.62(0.12)$ & (b) & $0.11(0.10)$ & (b) & (b) & $0.40(0.05)$ & $0.53(0.20)$ \\
\hline 2002 & (b) & $0.70(0.12)$ & (b) & (b) & (b) & (b) & (b) & $0.61(0.17)$ \\
\hline 2003 & (b) & $0.83(0.26)$ & (b) & (b) & (b) & (b) & (b) & $0.64(0.12)$ \\
\hline 2004 & (b) & $0.31(0.13)$ & (b) & (b) & (b) & (b) & (b) & $0.44(0.16)$ \\
\hline 2005 & (b) & $0.90(0.22)$ & (b) & $0.19(0.11)$ & (b) & (b) & (b) & $0.54(0.12)$ \\
\hline 2006 & (b) & $0.46(0.11)$ & (b) & $0.18(0.08)$ & (b) & (b) & (b) & $0.68(0.14)$ \\
\hline Average & 0.44 & 0.65 & -- & 0.16 & 0.46 & -- & 0.34 & 0.59 \\
\hline
\end{tabular}

Overall performance of hatchery smolts has been variable and less than satisfactory for most species. In-basin survival estimates have averaged $31 \%$ for coho salmon, $38 \%$ for summer steelhead, 59\% for subyearling fall Chinook salmon, 62\% for spring Chinook salmon, and 70\% for yearling fall Chinook salmon (Table 10). Improved detection capabilities at TMFD and application of the SURPH 2 Model has provided more robust in-basin estimates over the past 3 years. Out-of-basin estimates from TMFD to JDD have ranged from 52\% in hatchery subyearling fall Chinook salmon to $70 \%$ in hatchery coho salmon (Table 10).

Monitoring of hatchery release groups has shown no significant difference in survival between standard-transferred and fall-transferred (overwintered) hatchery spring Chinook salmon (Table 11). Yearling fall Chinook and coho salmon released in April survived at a higher rate than those released in March (Tables 12 and 13). Subyearling fall Chinook salmon direct-released at RM 48.5 generally survive at a higher rate than those acclimated and released at RM 73.5 (Table 14). Summer steelhead released low in the basin consistently outperform those released higher up (Table 15).

Inter-annual variation in the survival of salmon and steelhead is a result of numerous factors, including spatial and temporal distribution of release, type of release, size at tagging and/or release, rearing strategies, rate of residualism, water flow and temperature, turbidity, and the number of fish tagged. The error associated with most estimates in our time series data is too great to directly link survival to any one variant with a high degree of confidence. As the number of fish tagged is increased and errors reduced, we will be able to better evaluate the key variables influencing the survival of hatchery and natural smolts in the Umatilla River. 
Table 10. In- and out-of-basin survival estimates for juvenile hatchery salmon and steelhead released in the Umatilla River, 1995-2006. Standard errors are in parentheses.

\begin{tabular}{|c|c|c|c|c|c|c|c|c|c|c|}
\hline \multirow[b]{3}{*}{$\begin{array}{l}\text { Outmigration } \\
\text { year }^{\mathrm{a}}\end{array}$} & \multicolumn{10}{|c|}{ Species } \\
\hline & \multicolumn{2}{|c|}{ Spring Chinook salmon } & \multicolumn{2}{|c|}{ Fall Chinook salmon $(+1)$} & \multicolumn{2}{|c|}{ Fall Chinook salmon $(+0)$} & \multicolumn{2}{|c|}{ Coho salmon } & \multicolumn{2}{|c|}{ Summer steelhead } \\
\hline & $\begin{array}{c}\text { Release to } \\
\text { TMFD } \\
\end{array}$ & $\begin{array}{c}\text { TMFD to } \\
\text { JDD }\end{array}$ & $\begin{array}{c}\text { Release to } \\
\text { TMFD } \\
\end{array}$ & $\begin{array}{c}\text { TMFD to } \\
\text { JDD }\end{array}$ & $\begin{array}{c}\text { Release to } \\
\text { TMFD } \\
\end{array}$ & $\begin{array}{c}\text { TMFD to } \\
\text { JDD }\end{array}$ & $\begin{array}{c}\text { Release to } \\
\text { TMFD }\end{array}$ & $\begin{array}{c}\text { TMFD to } \\
\text { JDD }\end{array}$ & $\begin{array}{c}\text { Release to } \\
\text { TMFD }\end{array}$ & $\begin{array}{c}\text { TMFD to } \\
\text { JDD }\end{array}$ \\
\hline 1995 & $0.67(\mathrm{~b})$ & -- & (b) & -- & $0.18(b)$ & -- & (b) & -- & (b) & -- \\
\hline 1996 & $0.34(0.39)$ & -- & $0.40(0.03)$ & -- & $1.41(0.02)$ & -- & $0.38(0.03)$ & -- & $0.94(0.05)$ & -- \\
\hline 1997 & (b) & -- & (b) & -- & $0.35(0.03)$ & -- & $0.34(0.10)$ & -- & (b) & -- \\
\hline 1998 & $0.73(0.03)$ & -- & $0.70(0.08)$ & -- & $1.52(0.04)$ & -- & $1.29(0.06)$ & -- & $0.50(0.04)$ & -- \\
\hline 1999 & $0.45(0.13)$ & (b) & $0.76(0.17)$ & (b) & $0.51(0.04)$ & (b) & -- & -- & $0.36(0.06)$ & (b) \\
\hline 2000 & $0.67(0.10)$ & $0.60(0.11)$ & $0.82(0.50)$ & $0.50(0.17)$ & $0.91(0.04)$ & $0.49(0.06)$ & -- & -- & $0.23(0.03)$ & $0.60(0.16)$ \\
\hline 2001 & $0.65(0.06)$ & $0.57(0.06)$ & $0.65(0.07)$ & $0.71(0.11)$ & $0.54(0.03)$ & $0.58(0.11)$ & $0.47(0.11)$ & $0.42(0.16)$ & $0.30(0.04)$ & $0.30(0.06)$ \\
\hline 2002 & $0.59(0.05)$ & $0.55(0.07)$ & $0.81(0.17)$ & $0.52(0.16)$ & $0.49(0.03)$ & $0.53(0.14)$ & $0.39(0.04)$ & $0.74(0.18)$ & $0.36(0.03)$ & $0.75(0.20)$ \\
\hline 2003 & $0.81(0.13)$ & $0.47(0.10)$ & $0.70(0.09)$ & $0.69(0.17)$ & $0.47(0.05)$ & $0.59(0.10)$ & $0.27(0.03)$ & $0.66(0.10)$ & $0.34(0.08)$ & $0.50(0.17)$ \\
\hline 2004 & $0.65(0.10)$ & $0.61(0.14)$ & $0.76(0.10)$ & $0.67(0.31)$ & $0.62(0.06)$ & $0.69(0.19)$ & $0.24(0.05)$ & $2.24(2.18)$ & $0.44(0.07)$ & $1.09(0.58)$ \\
\hline 2005 & $0.61(0.07)$ & $0.57(0.10)$ & $0.48(0.11)$ & $0.90(0.48)$ & $0.70(0.11)$ & $0.30(0.15)$ & $0.27(0.05)$ & $0.91(0.49)$ & $0.58(0.08)$ & $0.61(0.21)$ \\
\hline $2006^{\mathrm{c}}$ & $0.53(0.04)$ & $0.54(0.09)$ & $0.65(0.04)$ & $0.70(0.12)$ & $0.45(0.05)$ & $0.49(0.15)$ & $0.23(0.03)$ & $0.78(0.35)$ & $0.41(0.01)$ & $0.64(0.08)$ \\
\hline Average $^{\mathrm{d}}$ & 0.62 & 0.56 & 0.70 & 0.67 & 0.59 & 0.52 & 0.31 & 0.70 & 0.38 & 0.57 \\
\hline
\end{tabular}

${ }^{a}$ Survival estimates for 1995-1998 were calculated using the Migrant Abundance methodology (Dauble et al. 1993). CJS survival estimates were calculated by the computer program SURPH (Lady et al. 2001) for 1999-2006.

b Insufficient data to calculate survival estimate and/or standard error.

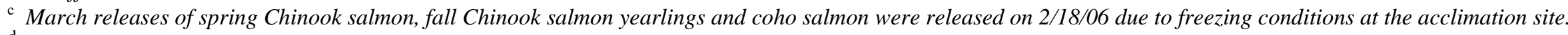

d Average is calculated using CJS survival estimates only, and does not include estimates that exceed 1.00 
Table 11. In- and out-of-basin survival estimates for standard- and fall-transferred spring Chinook salmon reared at Umatilla Fish Hatchery, 1999-2006. Standard errors are in parentheses.

\begin{tabular}{|c|c|c|c|c|}
\hline \multirow{4}{*}{$\begin{array}{l}\text { Outmigration } \\
\text { year }^{\mathrm{a}}\end{array}$} & \multicolumn{4}{|c|}{ Treatment group } \\
\hline & \multicolumn{2}{|c|}{ Standard-transfer } & \multicolumn{2}{|c|}{ Fall-transfer } \\
\hline & Release to & TMFD to & Release to & TMFD to \\
\hline & TMFD & JDD & TMFD & JDD \\
\hline 1999 & $0.45(0.13)$ & (b) & $0.33(0.30)$ & (b) \\
\hline 2000 & $0.35(0.13)$ & $1.10(0.43)$ & $0.89(0.55)$ & $0.81(0.57)$ \\
\hline 2001 & $0.63(0.10)$ & $0.53(0.10)$ & $0.47(0.07)$ & $0.79(0.16)$ \\
\hline 2002 & $0.73(0.16)$ & $0.71(0.25)$ & $0.63(0.13)$ & $0.47(0.13)$ \\
\hline 2003 & $0.91(0.33)$ & $0.53(0.25)$ & $0.70(0.27)$ & $0.92(0.54)$ \\
\hline 2004 & $0.56(0.33)$ & $0.76(0.48)$ & $0.49(0.30)$ & $0.59(0.39)$ \\
\hline 2005 & $0.58(0.10)$ & $0.46(0.11)$ & $0.68(0.14)$ & $0.64(0.20)$ \\
\hline $2006^{\mathrm{c}}$ & $0.50(0.07)$ & $0.70(0.29)$ & $0.53(0.10)$ & $0.54(0.18)$ \\
\hline Average $^{\mathrm{d}}$ & 0.59 & 0.62 & 0.59 & 0.68 \\
\hline
\end{tabular}

${ }^{a}$ All standard- and fall-transfer fish reared in Oregon raceways for migration years 1999-2003 and Michigan raceways for migration years 2004-2006.

b Insufficient data to calculate a survival estimate.

c Fish were released on 2/18/06.due to freezing conditions at the acclimation site.

d Average does not include estimates that exceed 1.00

Table 12. In- and out-of-basin survival estimates for March and April released yearling fall Chinook salmon reared at Bonneville Fish Hatchery, 1999-2006. Standard errors are in parentheses.

\begin{tabular}{|c|c|c|c|c|}
\hline \multirow{4}{*}{$\begin{array}{l}\text { Outmigration } \\
\text { year }\end{array}$} & \multicolumn{4}{|c|}{ Treatment group } \\
\hline & \multicolumn{2}{|c|}{ March release } & \multicolumn{2}{|c|}{ April release } \\
\hline & Release to & TMFD to & Release to & TMFD to \\
\hline & TMFD & JDD & TMFD & JDD \\
\hline 1999 & $0.50(0.10)$ & (b) & $0.76(0.17)$ & (b) \\
\hline 2000 & $0.82(0.50)$ & $0.68(0.50)$ & $0.76(0.18)$ & $0.39(0.15)$ \\
\hline 2001 & $0.46(0.12)$ & $0.67(0.20)$ & $0.80(0.10)$ & $0.75(0.14)$ \\
\hline 2002 & $0.70(0.19)$ & $0.34(0.13)$ & $0.73(0.24)$ & $0.93(0.45)$ \\
\hline 2003 & $0.47(0.17)$ & $0.69(0.31)$ & $0.85(0.11)$ & $0.74(0.23)$ \\
\hline 2004 & $0.79(0.35)$ & $0.38(0.28)$ & $0.89(0.10)$ & $0.88(0.56)$ \\
\hline $2005^{\mathrm{a}}$ & $0.41(0.25)$ & (b) & $0.63(0.15)$ & $0.75(0.39)$ \\
\hline 2006 & $0.49(0.10)^{\mathrm{c}}$ & $0.59(0.24)^{\mathrm{c}}$ & $0.86(0.05)$ & $0.71(0.14)$ \\
\hline Average & 0.58 & 0.56 & 0.79 & 0.74 \\
\hline
\end{tabular}


Table 13. In- and out-of-basin survival estimates for March and April released juvenile coho salmon acclimated and released at RM 56, 2001-2006. Standard errors are in parentheses.

\begin{tabular}{|c|c|c|c|c|c|c|}
\hline \multirow[b]{4}{*}{$\begin{array}{l}\text { Outmigration } \\
\text { year }\end{array}$} & \multicolumn{6}{|c|}{ Treatment group } \\
\hline & \multirow{2}{*}{\multicolumn{2}{|c|}{$\begin{array}{c}\begin{array}{c}\text { Oxbow/Lower Herman Creek } \\
\text { Hatchery }\end{array} \\
\text { March release } \\
\end{array}$}} & \multicolumn{4}{|c|}{ Cascade Hatchery } \\
\hline & & & \multicolumn{2}{|c|}{ March release } & \multicolumn{2}{|c|}{ April release } \\
\hline & $\begin{array}{c}\text { Release to } \\
\text { TMFD }\end{array}$ & $\begin{array}{l}\text { TMFD to } \\
\text { JDD }\end{array}$ & $\begin{array}{c}\text { Release to } \\
\text { TMFD }\end{array}$ & $\begin{array}{c}\text { TMFD to } \\
\text { JDD }\end{array}$ & $\begin{array}{c}\text { Release to } \\
\text { TMFD }\end{array}$ & $\begin{array}{c}\text { TMFD to } \\
\text { JDD }\end{array}$ \\
\hline 2001 & (b) & (b) & $0.58(0.53)$ & $0.18(0.22)$ & $0.64(0.15)$ & $0.45(0.17)$ \\
\hline 2002 & $0.43(0.16)$ & $0.38(0.20)$ & $0.61(0.31)$ & $0.26(0.16)$ & $0.43(0.05)$ & $1.32(0.53)$ \\
\hline 2003 & $0.13(0.04)$ & $0.70(0.29)$ & $0.19(0.04)$ & $0.93(0.32)$ & $0.38(0.05)$ & $0.59(0.11)$ \\
\hline 2004 & $0.30(0.27)$ & (b) & $0.28(0.17)$ & $0.94(1.01)$ & $0.26(0.06)$ & (b) \\
\hline $2005^{\mathrm{a}}$ & $0.39(0.24)$ & (b) & $0.19(0.06)$ & $1.18(1.07)$ & $0.34(0.10)$ & $0.81(0.53)$ \\
\hline 2006 & -- & -- & $0.04(0.02)^{\mathrm{c}}$ & (b) & $0.41(0.06)$ & $0.68(0.30)$ \\
\hline \multirow{2}{*}{\multicolumn{7}{|c|}{ 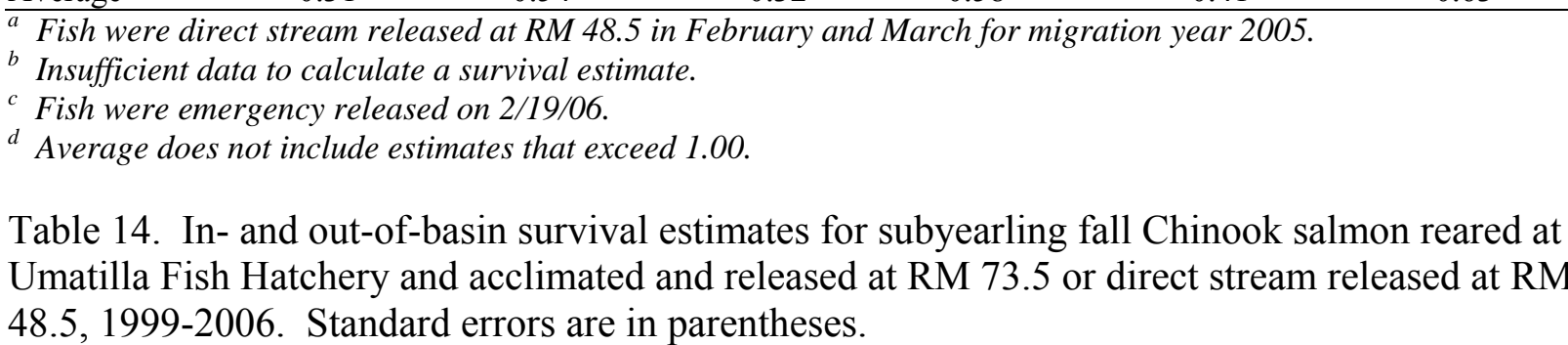 }} \\
\hline & & & & & & \\
\hline & \multicolumn{6}{|c|}{ Treatment group } \\
\hline & \multicolumn{3}{|c|}{ Acclimated (RM 73.5) } & \multicolumn{3}{|c|}{ Direct released (RM 48.5) } \\
\hline $\begin{array}{l}\text { Outmigration } \\
\text { year }^{\mathrm{a}}\end{array}$ & $\begin{array}{r}\text { Releas } \\
\text { TMF }\end{array}$ & & $\begin{array}{l}\text { TMFD to } \\
\text { JDD }\end{array}$ & $\begin{array}{r}\mathrm{Re} \\
\mathrm{T}\end{array}$ & & $\begin{array}{l}\text { TMFD to } \\
\text { JDD }\end{array}$ \\
\hline 1999 & $0.50(0$ & & (b) & & & -- \\
\hline 2000 & $1.05(0$ & & $0.85(0.47)$ & 1.0 & & $0.40(0.15)$ \\
\hline 2001 & $0.63(0$ & & $0.49(0.11)$ & 0.4 & & $0.75(0.27)$ \\
\hline 2002 & $0.21(0$ & & $2.16(2.02)$ & 0.7 & & $0.37(0.09)$ \\
\hline 2003 & $0.29(0$ & & $0.53(0.16)$ & 0.6 & & $0.62(0.12)$ \\
\hline 2004 & $0.54(0$ & & $0.88(0.36)$ & 0.6 & & $0.56(0.21)$ \\
\hline 2005 & -- & & -- & 0.7 & 11) & $0.30(0.15)$ \\
\hline 2006 & $0.57(0$ & & $0.43(0.20)$ & 0.3 & 05) & $0.49(0.21)$ \\
\hline Average $^{c}$ & 0.46 & & 0.64 & & & 0.50 \\
\hline
\end{tabular}


Table 15. In- and out-of-basin survival estimates for juvenile summer steelhead reared at Umatilla Fish Hatchery, 2002-2006. Acclimated and released at Bonifer Springs (RM 79), Minthorn Springs (RM 64.9), and Pendleton (RM 56).

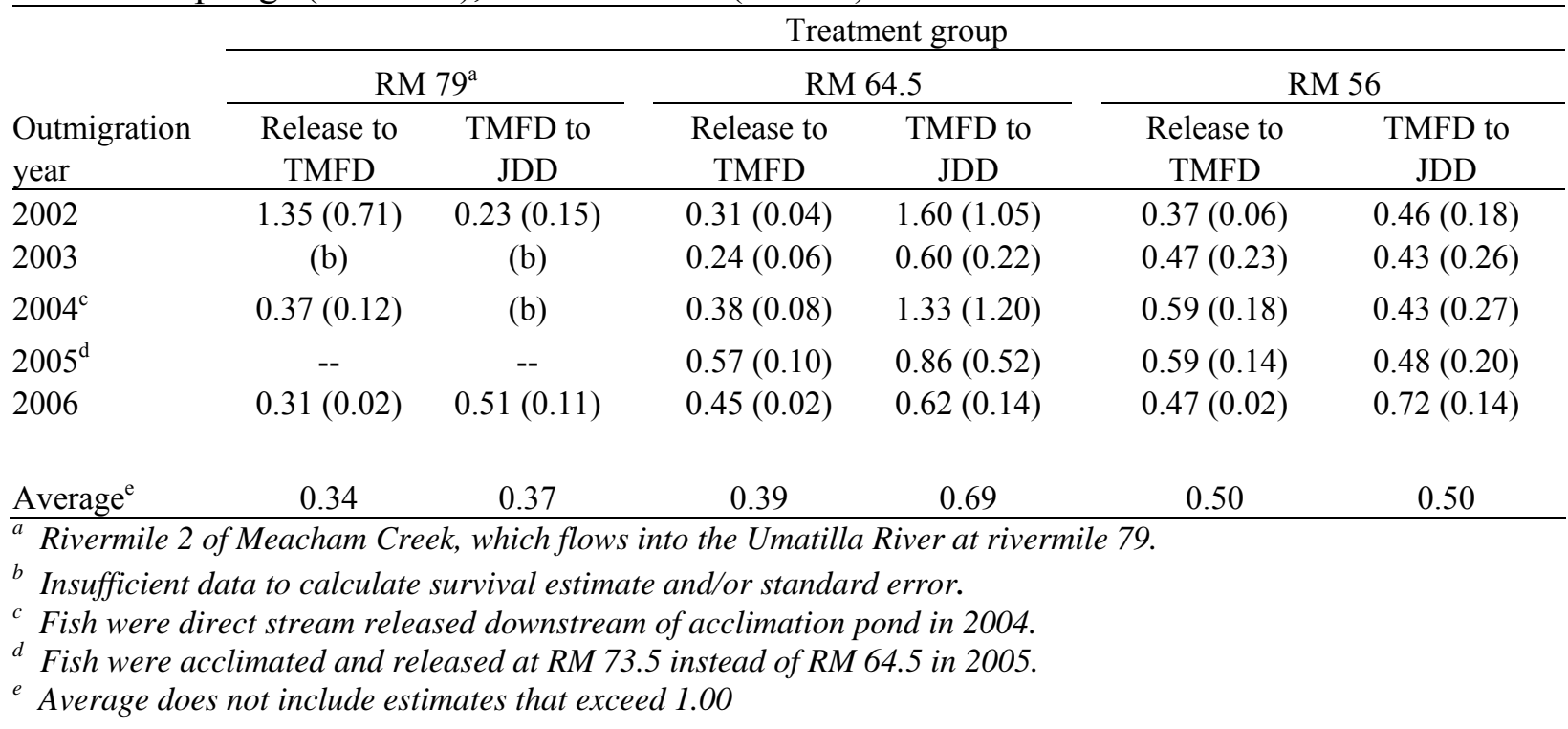

\section{PIT Tag Interrogation}

PIT-tag marking and remote interrogation has been successful and incrementally improved at TMFD since 1999. Software and hardware has been improved to enhance performance, reliability and remote system monitoring. Equipment in the juvenile bypass trap has progressed from a $400 \mathrm{kHz}$ detection system seven years ago, to a stationary antenna array $(134 \mathrm{kHz}) \mathrm{with}$ remote data transmission (Figures 17 and 18). Detection efficiency at the juvenile bypass is $99.9 \%$. A second antenna array (flatplate) was installed in the juvenile bypass outfall in 2005 to help monitor potential passage delays and interrogate fish during periods of non-trapping (Figures 17 and 19). Estimated efficiency of the outfall detector is 47.9\%, when the bypass is operating at 5 cfs.

Efforts to upgrade provisional PIT-tag detection equipment at the east bank adult fish ladder were unsuccessful in 2004 due to budgetary and logistical constraints. In 2005, designs plans and specifications to install a permanent adult ladder detector were completed (Appendix B). Plans included installation of 2 stationary pass-through antennas molded into high impact housing and mounted within the vertical slots (weir walls) of the adult fish ladder. Initial attempts to secure funding for the construction phase of the project were unsuccessful. However, in the spring of 2006 ODFW collaborated with the Bureau of Reclamation to enhance detection efficiency at the adult fish ladder. Paddle style antennas fed by portable transceivers were replaced with a single antenna enclosed in PVC piping and mounted to the backlight chamber of the viewing window (Figure 20). The new antenna array was powered by a multiplexer unit, which increased detection at the ladder location 3-fold (Figure 21). Mean juvenile detection efficiency at the adult ladder detector is currently $89 \%$.

Through the help of Pacific States Marine Fisheries Commission (PSMFC), additional upgrades were conducted in fall of 2006 to provide for remote system monitoring and coordination of data 
from all 3 detection arrays at TMFD (juvenile bypass trap, juvenile bypass outfall and adult fish ladder). Tag data from the two arrays along the west bank of the dam is now transmitted to the east bank of the dam via radio modem/antenna, so tag information from all 3 sites is currently uploaded at one central location (Figure 15). A phone line with modem was installed along the east bank of the dam to remotely upload PIT-tag data every 3 hours to the PTAGIS database. In addition, an electronics trailer equipped with climate control, was stationed along the east bank of the dam to house radio modems, transceivers and data logging equipment (Figure 17). The design scheme for the permanent adult ladder detector was incorporated into the upgrades. Therefore, should installation of the permanent interrogation system proceed, all necessary electronics and communication equipment is in place. 


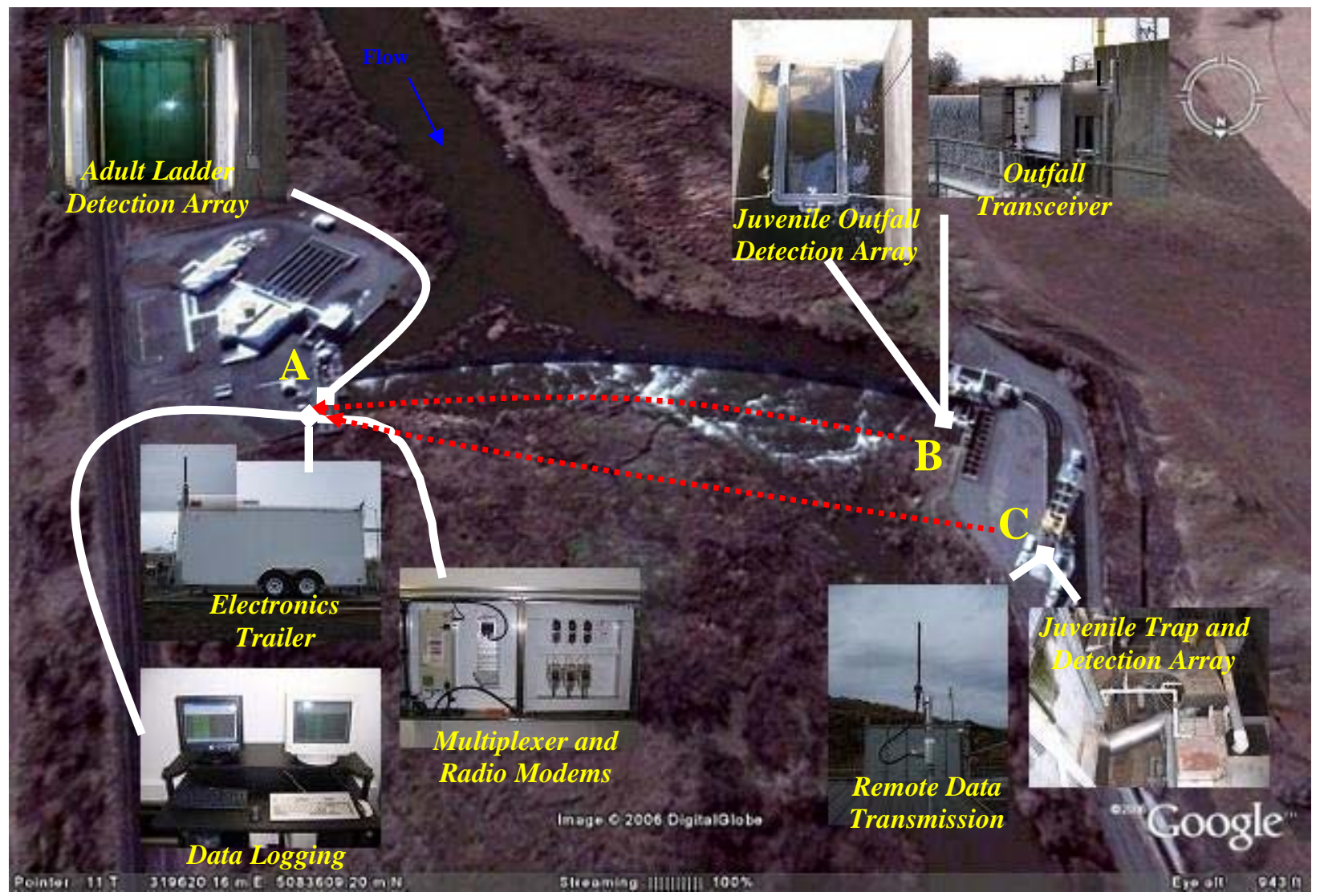

Figure 17. East (A) and West (B and C) bank PIT tag detection arrays at Three Mile Falls Dam.

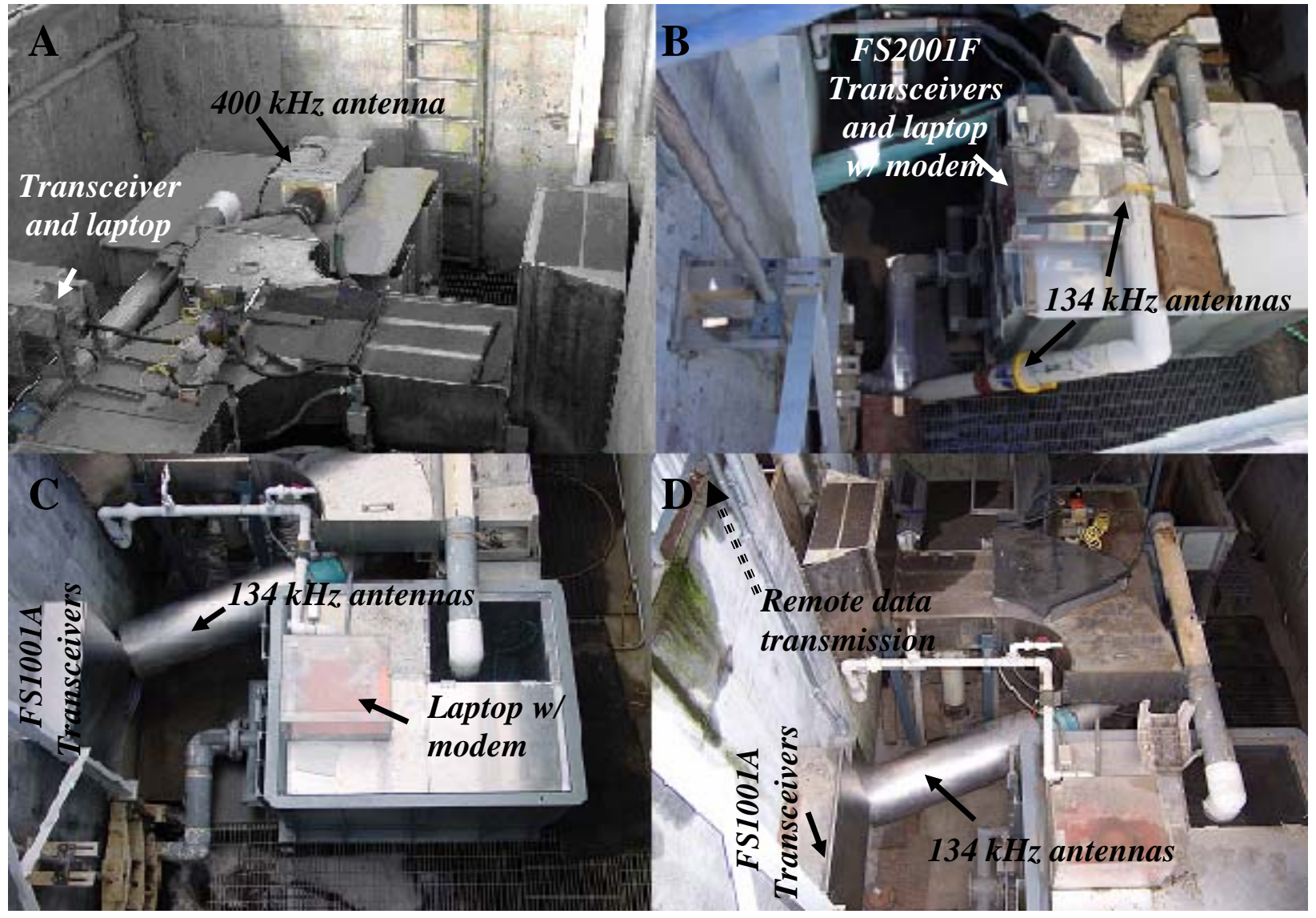

Figure 18. PIT tag detection array within the trap at the juvenile bypass facility in 1999 (A), 2000 (B), 2004 (C) and 2006 (D). 


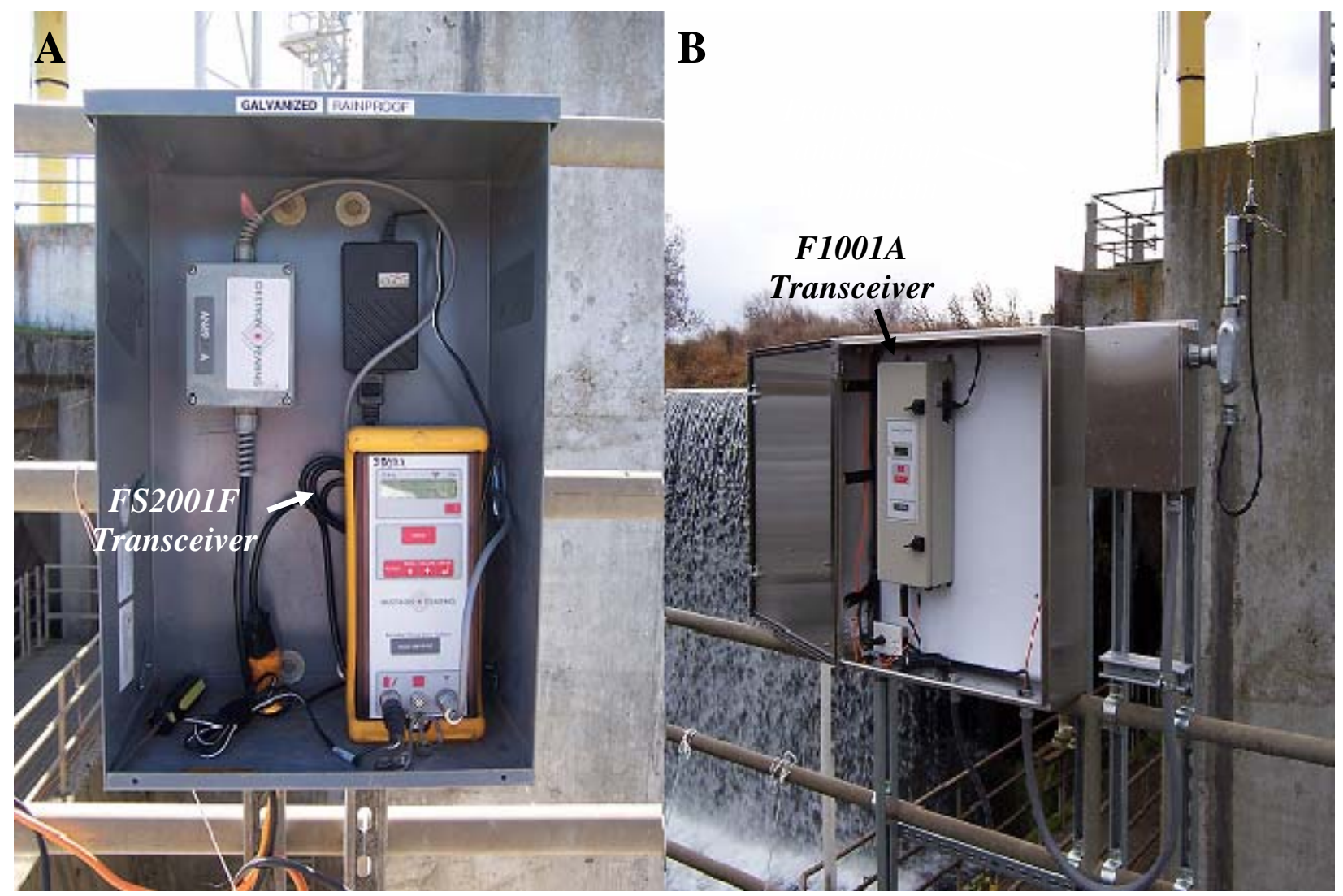

Figure 19. PIT tag detection array within the outfall at the juvenile bypass facility in 2005 (A) and $2006(\mathrm{~B})$.
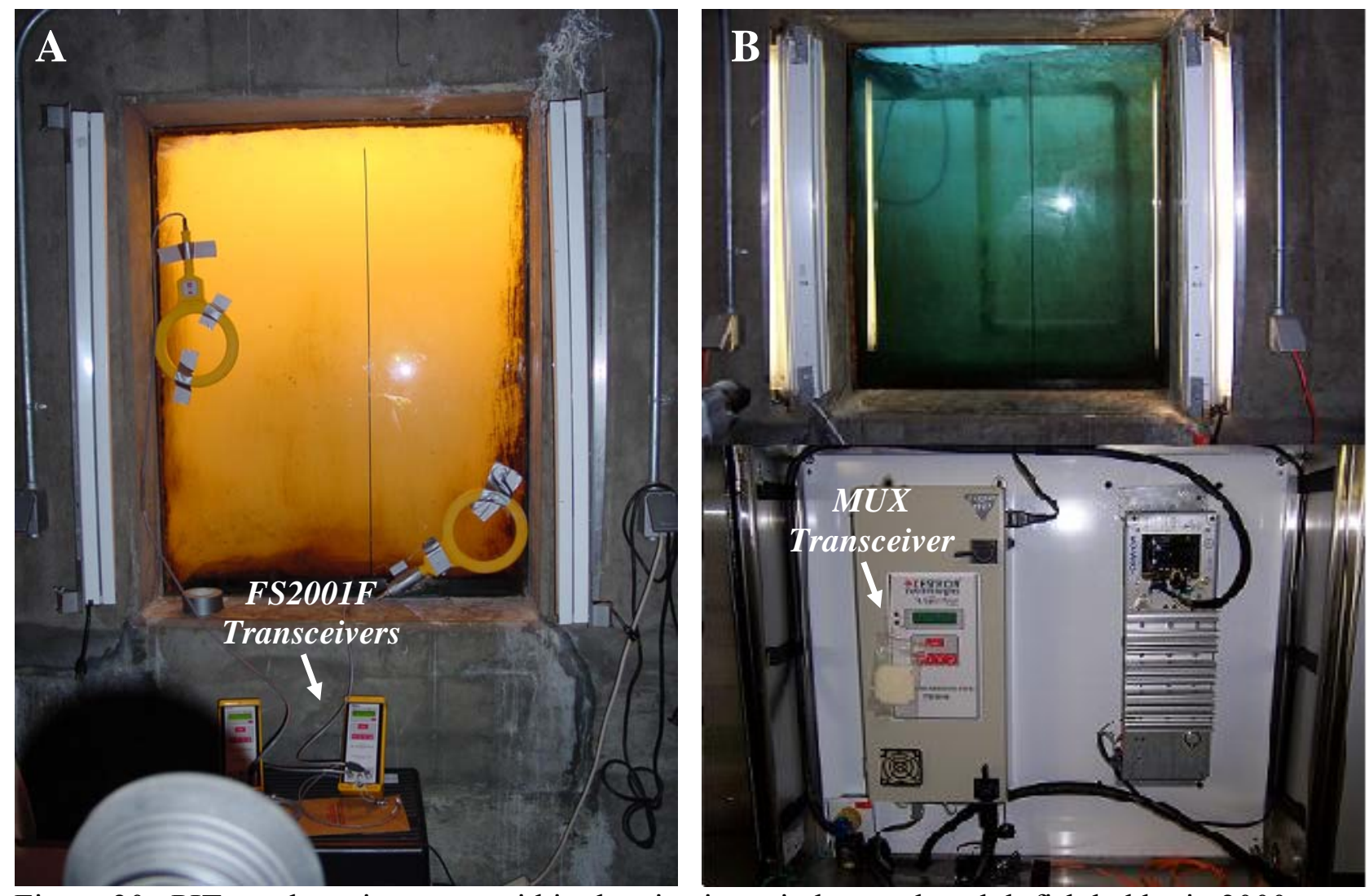

Figure 20. PIT tag detection array within the viewing window at the adult fish ladder in 2000 (A) and 2006 (B). 


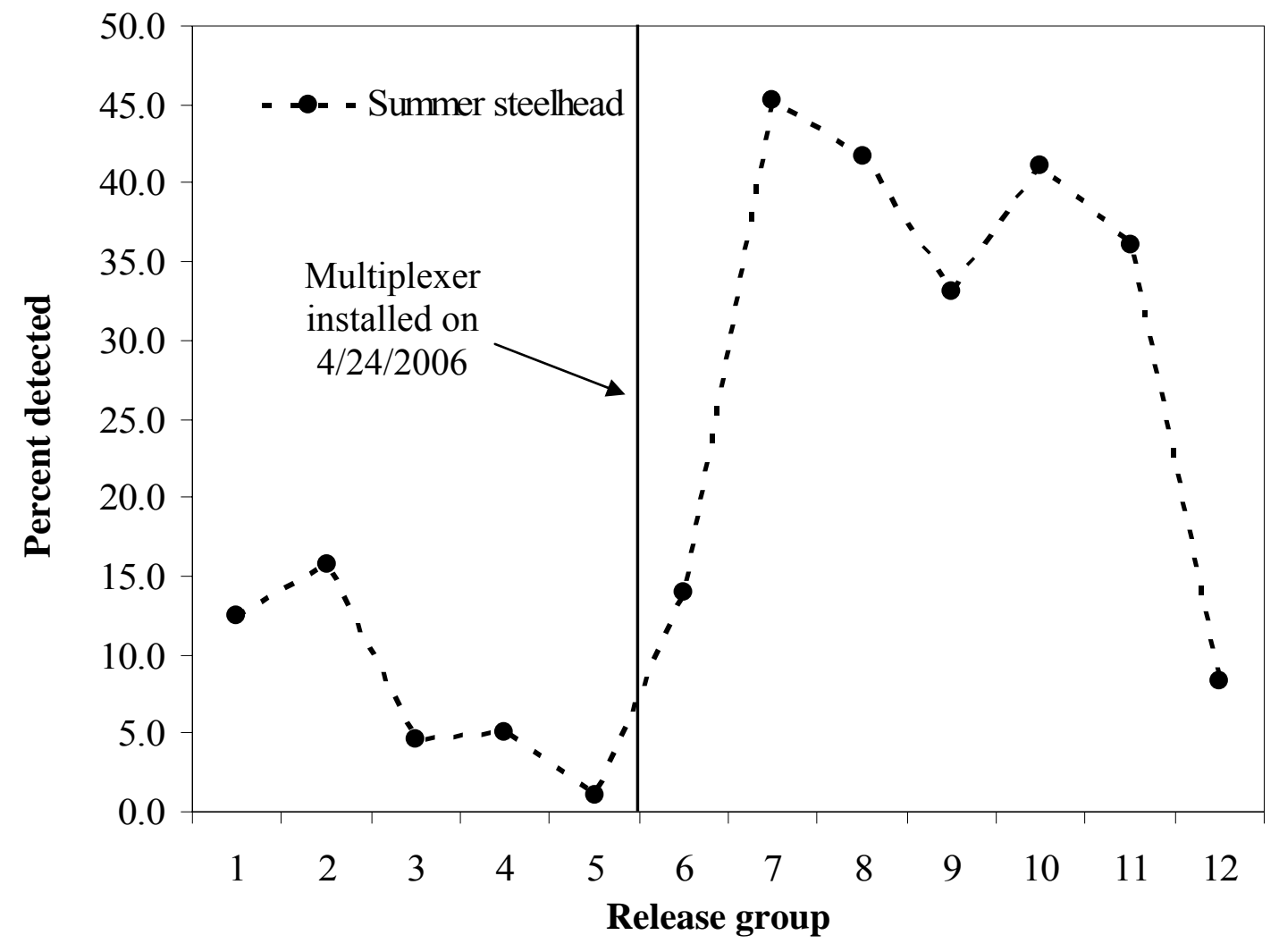

Figure 21. Improved detection efficiency of natural summer steelhead in the adult fish ladder at Three Mile Falls Dam, following installation of the multiplexer and upgraded antenna array, April 2006. Associative analysis suggests the low detection rate for the last release group (12) was a result of high flows.

\section{Resident Species and Lamprey}

Endemic species dominate the catch of resident species in the lower Umatilla River with several non-endemic species present in smaller numbers (Table 16. An increasing number of juvenile Pacific lamprey have been captured over the past three years despite a reduction in trapping efforts targeted at this species. The increase in juvenile numbers likely corresponds to the outplanting of adults in 2000 by CTUIR (Close 2002). A wide range in size and time of capture suggests that multiple life history strategies of both endemic and non-endemic species exist. In addition, temporal changes in the magnitude of resident fish and lamprey captured in lower river traps appear to be related to flow and temperature (Figure 22). 
Table 16 Number of non-target species and Pacific lamprey captured and length summary statistics, Umatilla River, 2004 - 2006.

Number captured is derived from both trapping sites, but not expanded for trap-efficiency or interpolated for unsampled periods.

Standard deviation in parenthesis.

\begin{tabular}{|c|c|c|c|c|c|c|c|c|c|c|c|c|}
\hline \multirow[b]{3}{*}{ Species } & \multicolumn{4}{|c|}{ Outmigration year 2004} & \multicolumn{4}{|c|}{ Outmigration year 2005} & \multicolumn{4}{|c|}{ Outmigration year 2006} \\
\hline & \multirow{2}{*}{$\begin{array}{c}\text { No. } \\
\text { captured }\end{array}$} & \multicolumn{3}{|c|}{ Fork length } & \multirow{2}{*}{$\begin{array}{c}\text { No. } \\
\text { captured }\end{array}$} & \multicolumn{3}{|c|}{ Fork length } & \multirow{2}{*}{$\begin{array}{c}\text { No. } \\
\text { captured }\end{array}$} & \multicolumn{3}{|c|}{ Fork length } \\
\hline & & $\mathrm{N}^{\mathrm{a}}$ & Mean & Range & & $\mathrm{N}^{\mathrm{a}}$ & Mean & Range & & $\mathrm{N}^{\mathrm{a}}$ & Mean & Range \\
\hline Adult lamprey & 3 & 3 & $449(41)$ & $470-545$ & 1 & 1 & $470(--)$ & 470 & -- & -- & -- & -- \\
\hline Bluegill & 115 & 110 & $53(24)$ & $25-156$ & 15 & 15 & $100(14)$ & $70-118$ & 30 & 30 & $104(24)$ & $43-149$ \\
\hline Bullhead sp. & 304 & 269 & $71(37)$ & $28-223$ & 20 & 15 & $86(56)$ & $30-186$ & 212 & 81 & $99(61)$ & $38-282$ \\
\hline Chiselmouth & 590 & 506 & $167(61)$ & $26-292$ & 439 & 308 & $139(69)$ & $39-288$ & 270 & 154 & $169(26)$ & $101-260$ \\
\hline Common carp & 2 & 1 & $24(--)$ & 24 & -- & -- & -- & -- & 6 & 5 & $134(37)$ & $88-170$ \\
\hline Crappie sp. & 20 & 19 & $79(42)$ & $27-164$ & 9 & 9 & $107(28)$ & $83-159$ & 1 & -- & -- & -- \\
\hline Dace sp. & 96 & 96 & $48(7)$ & $31-75$ & 130 & 122 & $45(5)$ & $35-65$ & 2 & 2 & $55(0)$ & 55 \\
\hline Largemouth bass & 816 & 80 & $42(43)$ & $23-340$ & 7 & 7 & $71(18)$ & $56-107$ & 7 & 6 & $46(10)$ & $33-60$ \\
\hline Larvae lamprey & 164 & 154 & $137(30)$ & $48-192$ & 120 & 74 & $126(37)$ & $56-177$ & 404 & 82 & $146(9)$ & $130-169$ \\
\hline Metamorphosed lamprey & 34 & 34 & $139(14)$ & $115-167$ & 349 & 119 & $137(12)$ & $106-171$ & 29 & 3 & $153(11)$ & $140-160$ \\
\hline Mosquitofish & 1 & 1 & $26(--)$ & 26 & -- & -- & -- & -- & 1 & -- & -- & -- \\
\hline Mountain whitefish & -- & -- & -- & -- & 1 & 1 & $183(--)$ & 183 & 44 & 33 & $186(15)$ & $152-213$ \\
\hline Northern pikeminnow & 127 & 126 & $212(46)$ & $68-283$ & 145 & 32 & $175(41)$ & $50-230$ & 85 & 84 & $216(40)$ & $86-300$ \\
\hline O. mykiss kelt & 2 & 2 & $586(35)$ & $561-610$ & -- & -- & -- & -- & 19 & 19 & $644(69)$ & $540-750$ \\
\hline Redside shiner & 31 & 27 & $65(25)$ & $25-163$ & 13 & 11 & $43(13)$ & $26-59$ & 7 & 3 & $63(5)$ & 59-68 \\
\hline Sculpin sp. & 5 & 5 & $90(64)$ & $19-147$ & 1 & 1 & $121(--)$ & 121 & 7 & 6 & $105(5)$ & $100-110$ \\
\hline Smallmouth bass & 65 & 65 & $108(38)$ & $24-212$ & 245 & 91 & $102(35)$ & $56-287$ & 122 & 99 & $133(41)$ & $73-310$ \\
\hline Sucker sp. & 1,249 & 982 & $151(53)$ & $24-445$ & 468 & 297 & $153(51)$ & $15-254$ & 708 & 447 & $187(55)$ & $62-470$ \\
\hline Sunfish sp. & -- & -- & -- & -- & -- & -- & -- & -- & 1 & 1 & $129(--)$ & 129 \\
\hline Yellow perch & 670 & 634 & $62(14)$ & 23-191 & 29 & 29 & $109(45)$ & $25-169$ & 30 & 28 & $80(32)$ & $55-169$ \\
\hline Total & 4,294 & 3,114 & $119(68)$ & $19-610$ & 1,992 & 1,132 & $126(60)$ & $15-470$ & 1,985 & 1,083 & $173(86)$ & $33-750$ \\
\hline
\end{tabular}




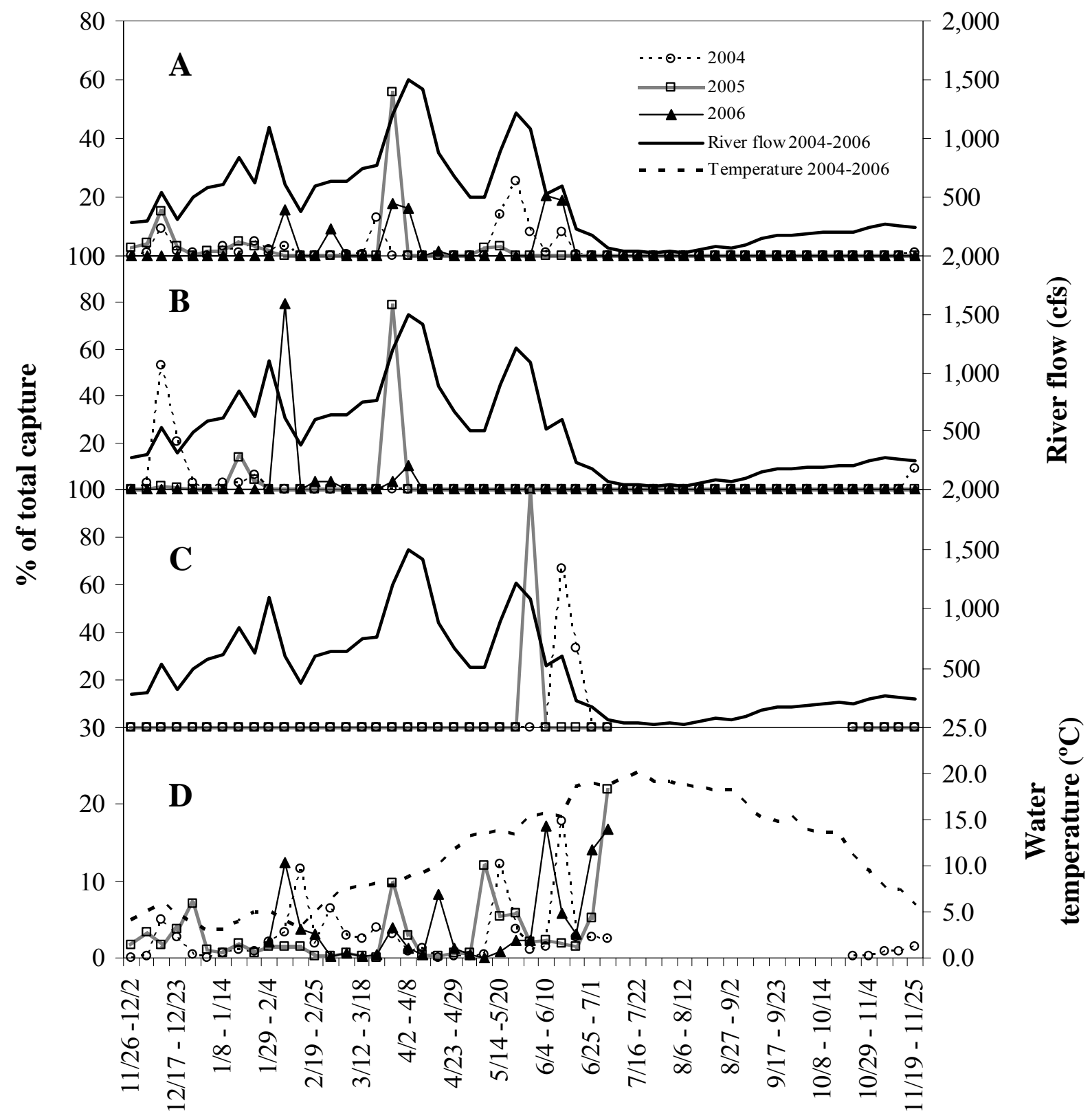

\section{Week}

Figure 22. Capture timing of larvae (A), metamorphosed (B), and adult (C) Pacific lamprey and non-target species (D) in the Umatilla River, 2004-2006. Data includes both trapping sites and gaps in data series indicate periods when traps were not operating. 


\section{CONCLUSIONS AND RECOMMENDATIONS}

Information gathered by the ODFW's Umatilla Juvenile Outmigration and Survival M\&E Project between 2004-2006 has helped characterize the status and trends of juvenile salmonids in the Umatilla River subbasin, provided insight into the effects of river flow, canal flow, water temperature, and other environmental variables on fish passage and survival, helped evaluate juvenile life history characteristics and trends in natural production and aided in monitoring the movement of juvenile Pacific lamprey and resident fish.

The following recommendations are provided to assist in adaptive management of the Umatilla subbasin and answering critical uncertainties of the fisheries resource.

1. Juvenile outmigration and survival monitoring is important for the long-term tracking of population responses over time. Information collected on smolt abundance, survival and life history characteristics is essential for characterizing the status and trends of salmon and steelhead populations in the Umatilla River subbasin and is needed to evaluate in-basin capacity, productivity and ascertain loss by life-stage. Productivity metrics produced from project data are the key subbasin scale measure of the effectiveness of salmon and steelhead restoration actions in the Umatilla River subbasin.

Recommendation: Continued monitoring at TMFD will provide critical information on key performance measures including smolts-per-spawner, egg-to-smolt survival and smolt-toadult return rates for naturally-produced and hatchery-reared salmon and steelhead in the Umatilla basin. These metrics enable us to look at productivity across multiple phases of the salmon/steelhead lifecycle and better ascertain limiting factors within and outside the basin.

2. Data collected by this project is critical to MCR Recovery Planning of ESA-listed summer steelhead and the 2004 Biological Opinion Remand Process. Although relatively small (10 yr lifespan) the Umatilla dataset is one of the only long-term datasets available for summer steelhead in the MCR ESU that allows us to look at life-stage specific survival at a tributary level. There is currently a large void in PIT-tag migration and survival data for MCR summer steelhead that is hampering efforts to identify recovery needs for these fish.

Recommendation: Additional PIT-tagging of natural summer steelhead is necessary to support SAR estimates and better understand the effects of lower Columbia River dams on listed populations.

3. The MCR recovery team is building a model to analyze the effects of tributary habitat actions on steelhead viability and the Umatilla dataset is being used to test the model. The smolt data is essential for modeling to understand how tributary, habitat, hatchery and hydrosystem actions influence productivity.

Recommendation: Continue to estimate smolt abundance, migration timing and survival of ESA-listed natural summer steelhead to assist in development of recovery goals for these fish. 
4. PIT-tag interrogation has been successful and incrementally improved at TMFD since 1999. Over the past 3 years, equipment has been upgraded, detection efficiency enhanced and tag information coordinated to remotely upload at one central location. As a result, we have observed more robust estimates in smolt survival and comparisons of migration timing for hatchery and natural salmonids.

Recommendation: Continue to PIT-tag hatchery and natural smolts and monitor trends in natural abundance. Enhance detection efficiency and estimates of smolt survival at TMFD through installation (construction) of the permanent PIT-tag detection system in the east bank adult ladder.

5. Data suggests passage route selection at TMFD is influenced by canal diversion.

Recommendation: Installation of a permanent PIT-tag detection system in the adult fish ladder would further enhance the understanding of route selection past TMFD during canal diversion and various flow enhancement strategies.

6. An increased understanding of flow enhancement efforts and their effects on all life stages of salmonids is required to effectively manage water in the Umatilla River.

Recommendation: Additional research should be conducted to identify the potential affects of McKay Reservoir releases on natural and hatchery salmonids, particularly subyearling fall Chinook salmon. 


\section{LITTERATURE CITED}

Beckman, B.R., D.A. Larsen, C. Sharpe, B. Lee-Pawlak, C.B. Schreck, and W.W. Dickhoff. 2000. Physiological status of naturally reared juvenile spring chinook salmon in the Yakima River: seasonal dynamics and changes associated with smolting. Transactions of the American Fisheries Society 129:727-753.

Berg, L. and D. Fast. 2002. Draft Yakima subbasin summary. Report prepared for the Northwest Power Planning Council, Portland, Oregon.

Cameron, W.A., S.M.Knapp, and R.W. Carmichael. 1997. Evaluation of juvenile salmonid bypass facilities and passage at water diversions on the lower Umatilla River. Final Report to Bonneville Power Administration, Portland, Oregon.

CBFWA PITTag Steering Committee 1999. PIT-tag marking station procedural manual. Version 1.0

Contor, C.R., E. Hoverson, P. Kissner, and J. Volkman. 1997. Umatilla basin natural production monitoring and evaluation: annual progress report 1995-1996. Prepared by the Confederated Tribes of the Umatilla Indian Reservation for the Bonneville Power Administration, Portland, Oregon.

Contor, C.R., E. Hoverson, P. Kissner. 2000. Umatilla basin natural production monitoring and evaluation: annual progress report 1997-1998. Prepared by the Confederated Tribes of the Umatilla Indian Reservation for the Bonneville Power Administration, Portland, Oregon.

Contor, C.R, editor. 2003. Umatilla basin natural production monitoring and evaluation: annual progress report 1999-2002. Prepared by the Confederated Tribes of the Umatilla Indian Reservation for the Bonneville Power Administration, Portland, Oregon.

Close, D.A. 2002. Pacific lamprey research and restoration project: annual report 2000. Prepared by the Confederated Tribes of the Umatilla Indian Reservation for the Bonneville Power Administration, Portland, Oregon.

Collis, K., D.D. Roby, D.P. Craig, B.A. Ryan, and R.D. Ledgerwood. 2001. Colonial waterbird predation on juvenile salmonids tagged with passive integrated transponders in the Columbia River estuary: vulnerability of different salmonid species, stocks, and rearing types. Transactions of the American Fisheries Society 130:385-396.

CTUIR (Confederated Tribes of the Umatilla Indian Reservation) and ODFW (Oregon Department of Fish and Wildlife). 1984. Umatilla basin recommended salmon and steelhead habitat improvement measures. Prepared for the Northwest Power Planning Council for Columbia basin system planning.

CTUIR and ODFW. 1989. Umatilla River subbasin - salmon and steelhead plan. Prepared for the Northwest Power Planning Council for Columbia basin system planning. 
CTUIR and ODFW. 2006. Comprehensive Research, Monitoring and Evaluation Plan for Umatilla Summer Steelhead and Chinook Salmon. Prepared for US Department of Energy, Bonneville Power Administration and the Northwest Power and Conservation Council.

Dauble, D.D., J. Skalski, A. Hoffman, and A. E. Giorgi. 1993. Evaluation and application of statistical methods for estimating smolt survival, Report to the Bonneville Power Administration, Portland, Oregon

Debano, S., D. Wooster and six organizations. 2004. Umatilla/Willow subbasin plan. Prepared for the Northwest Power and Conservation Council. Available online at: http://www.nwcouncil.org/fw/subbasinplanning/umatilla/plan

Efron, B. and R. Tibshirani. 1986. Bootstrap methods for standard errors, confidence intervals, and other measures of statistical accuracy. Statistical Science 1(1): 54-77.

Fast, D., J.Hubble, M.Kohn, B. Watson. 1991. Yakima river spring Chinook enhancement study. Final report to Bonneville Power Administration, Portland, Oregon.

Gallinat, M.P., L. Ross, and M. Varney. 2003 Tucannon River spring Chinook salmon hatchery evaluation program: annual report 2002 Prepared for the U.S. Fish and Wildlife Service, Boise, Idaho.

Gallinat, M.P., and L.A. Ross. 2006. Tucannon River spring Chinook salmon hatchery evaluation program: annual report 2005Prepared for the U.S. Fish and Wildlife Service, Boise, Idaho.

Google Earth. 2006. Digital Image. Three Mile Falls Dam, Umatilla River Watershed.

Grant, G.C., W.A. Cameron, D.W. Chess, R.W. Stonecypher, T.C. White, R. Carmichael, C.C. Contor, P. Kissner, and G. James. 2007. Comprehensive assessment of summer steelhead and Chinook salmon restoration and enhancement efforts in the Umatilla River subbasin. Report years: 1991-2006. Prepared for US Department of Energy, Bonneville Power Administration and the Independent Scientific Review Panel.

Hanson, J.T., T.C. White, S.M. Jewett, and R.W. Carmichael. 2006. Evaluation of Juvenile salmonid outmigration and survival in the lower Umatilla River basin: Annual progress report 2002-2003 prepared by the Oregon Department of Fish and Wildlife for the Bonneville Power Administration, Portland, Oregon.

Keefe, M.L., R.W. Carmichael, S.M. Focher W.J. Groberg, and M.C. Hayes. 1994. Fish research project - Oregon. Umatilla Hatchery monitoring and evaluation: 1993 annual report. Oregon Department of Fish and Wildlife report to Bonneville Power Administration, Portland, Oregon. 
Kemp, P.S., M.H. Gessel, and J.G. Williams. 2005. Fine-scale behavioral responses of Pacific salmonid smolts as they encounter divergence and acceleration of flow. Transactions of the American Fisheries Society 134:390-398.

Knapp, S.M., D.L. Ehlers, J.C. Kern, W.A. Cameron, S.L. Shapleigh, and R.W. Carmichael. 1996. Evaluation of juvenile salmonid outmigration and survival in the lower Umatilla River basin, Annual report 1995, Prepared by the Oregon Department of Fish and Wildlife for the Bonneville Power Administration, Portland, Oregon.

Knapp, S.M., J.C. Kern, W.A. Cameron, S.M. Snedaker, and R.W. Carmichael. 1998a. Evaluation of juvenile salmonid outmigration and survival in the lower Umatilla River basin, Annual report 1996, Prepared by the Oregon Department of Fish and Wildlife for the Bonneville Power Administration, Portland, Oregon.

Knapp, S.M., W.A. Cameron, J.C. Kern, and R.W. Carmichael. 1998b. Evaluation of juvenile salmonid outmigration and survival in the lower Umatilla River basin, Annual report 1997, Prepared by the Oregon Department of Fish and Wildlife for the Bonneville Power Administration, Portland, Oregon.

Lady, J.P., Westhagen, J.R. and J.R. Skalski. 2001. SUPRH 2 User Manual. SURPH 2.1, Survival under Proportional Hazards. School of Aquatic and Fisheries Sciences, University of Washington, Seattle, WA http:/www.cqs.washington.edu/parmESt/SURPH.

Lind, D. 2006. Fisheries Biologist, Yakama Nation. Personnel Communication.

Lindsay, R.B., W.J. Knox, M.W. Flesher, B.J Smith, E.A. Olsen and L.S.Lutz. 1986. Study of wild spring Chinook salmon in the John Day River system. 1985 final report to Bonneville Power Administration, Portland, OR.

Mayer, K. and M. Schuck. 2004. Assess salmonids in Asotin Creek watershed. 2003-2004 annual progress report to Bonneville Power Administration, Portland, Oregon

NPPC (Northwest Power Planning Council. 1984. Columbia River basin fish and wildlife program. Northwest Power Planning Council, Portland, Oregon.

NPPC (Northwest Power Planning Council). 1987. Columbia River basin fish and wildlife program (as amended). Northwest Power Planning Council, Portland, Oregon.

NPPC (Northwest Power Planning Council). 1994. Columbia River basin fish and wildlife program. Northwest Power Planning Council, Portland, Oregon.

NPPC (Northwest Power Planning Council). 2000. Columbia River basin fish and wildlife program - A multi-species approach for decision-making. Northwest Power Planning Council, Portland, Oregon. 
ODFW. 1986. A comprehensive plan for rehabilitation of anadromous fish stocks in the Umatilla river basin. Final report by the Oregon Department of Fish and Wildlife to the Bonneville Power Administration, Portland, Oregon.

ODFW and CTUIR. 1989. Umatilla Hatchery Master Plan. Report for the Northwest Power Planning Council. Portland, Oregon.

Peven, C.M., R.R. Whitney, and K.R. Williams. 1994. Age and length of steelhead smolts from the Mid-Columbia River Basin, Washington. North American Journal of Fisheries Management 14:77-86.

Sandford, B.P. and T.E. Ruehle. 1996. Juvenile salmonid pit-tag studies at Prosser Dam and the Chandler Canal fish collection facility, Yakima River, 1991 and 1992. Final report prepared for the Bonneville Power Administration, Portland, Oregon.

Saul, D., C. Rabe, A. Davidson, and D. Rollins. 2001. Umatilla Subbasin Summary - Draft. Prepared for the Northwest Power Planning Council for the Columbia Plateau Rolling Provincial Review, August 2001.

Thedinga, J.F., M.L. Murphy, S.W. Johnson, J.M. Lorenz, and K.V. Koski. 1994. Determination of salmonid smolt yield with rotary-screw traps in the Situk River, Alaska, to predict effects of glacial flooding. North American Journal of Fisheries Management 14:837-851.

USBR (U|S Bureau of Reclammation). Hydromet Archives. http://www.usbr.gov/pn/hydromet/

USGS. Geological Survey (USGS). 1989. Hydrological unit map, State of Oregon. U.S. Geological Survey, Reston, Virginia.

White, T.C., S.M. Jewett, J.T. Hanson, and R.W. Carmichael. 2003. Evaluation of Juvenile salmonid outmigration and survival in the lower Umatilla River basin: Annual progress report 2000-2001 prepared by the Oregon Department of Fish and Wildlife for the Bonneville Power Administration, Portland, Oregon.

White, T.C., J.T. Hanson, S.M. Jewett, and R.W. Carmichael. 2004. Evaluation of Juvenile salmonid outmigration and survival in the lower Umatilla River basin: Annual progress report 2001-2002 prepared by the Oregon Department of Fish and Wildlife for the Bonneville Power Administration, Portland, Oregon.

Wilson, W.H. 2006. Fisheries Biologist, ODFW, John Day River Subbasin. Personnel communication. 


\section{APPENDIX A \\ Auxiliary Information from Outmigration Studies}


Appendix Table A-1. Week of $10^{\text {th }}, 50^{\text {th }}$, and $90^{\text {th }}$ percentiles of summer steelhead emigrating from the Umatilla River, $1995-2006$.

\begin{tabular}{|c|c|c|c|c|c|c|c|c|}
\hline \multirow[b]{2}{*}{$\begin{array}{l}\text { Outmigration } \\
\text { year }\end{array}$} & \multicolumn{4}{|c|}{ Natural summer steelhead } & \multicolumn{4}{|c|}{ Hatchery summer steelhead } \\
\hline & $\begin{array}{c}10 \% \\
\text { emigration } \\
\end{array}$ & $\begin{array}{c}50 \% \\
\text { emigration } \\
\end{array}$ & $\begin{array}{c}90 \% \\
\text { emigration } \\
\end{array}$ & $\begin{array}{c}\text { Peak } \\
\text { emigration }\end{array}$ & $\begin{array}{c}10 \% \\
\text { emigration } \\
\end{array}$ & $\begin{array}{c}50 \% \\
\text { emigration } \\
\end{array}$ & $\begin{array}{c}90 \% \\
\text { emigration } \\
\end{array}$ & $\begin{array}{c}\text { Peak } \\
\text { emigration } \\
\end{array}$ \\
\hline 1995 & $2 / 19-2 / 25$ & $4 / 23-4 / 29$ & $5 / 14-5 / 20$ & $4 / 23-4 / 29$ & $4 / 19-4 / 15$ & $4 / 23-4 / 29$ & $5 / 21-5 / 27$ & $4 / 23-4 / 29$ \\
\hline 1996 & $4 / 23-4 / 29$ & $5 / 14-5 / 20$ & $5 / 28-6 / 3$ & $5 / 14-5 / 20$ & $5 / 7-5 / 13$ & $5 / 14-5 / 20$ & $5 / 28-6 / 3$ & $5 / 14-5 / 20$ \\
\hline 1997 & $2 / 19-2 / 25$ & $4 / 23-4 / 29$ & $5 / 7-5 / 13$ & $4 / 23-4 / 29$ & $4 / 9-4 / 15$ & $4 / 30-5 / 6$ & $5 / 14-5 / 20$ & $4 / 30-5 / 6$ \\
\hline 1998 & $4 / 16-4 / 22$ & $4 / 30-5 / 6$ & $5 / 21-5 / 27$ & $4 / 23-4 / 29$ & $4 / 23-4 / 29$ & $4 / 30-5 / 6$ & $5 / 21-5 / 27$ & $4 / 30-5 / 6$ \\
\hline 1999 & $3 / 26-4 / 1$ & $5 / 21-5 / 27$ & $5 / 28-6 / 3$ & $5 / 21-5 / 27$ & $4 / 30-5 / 6$ & $5 / 21-5 / 27$ & $5 / 28-6 / 3$ & $5 / 21-5 / 27$ \\
\hline 2000 & $4 / 23-4 / 29$ & $4 / 30-5 / 6$ & $5 / 21-5 / 27$ & $4 / 30-5 / 6$ & $4 / 2-4 / 8$ & $4 / 30-5 / 6$ & $5 / 21-5 / 27$ & $4 / 30-5 / 6$ \\
\hline 2001 & $4 / 9-4 / 15$ & $5 / 21-5 / 27$ & $5 / 28-6 / 3$ & $5 / 21-5 / 27$ & $4 / 9-4 / 15$ & $4 / 30-5 / 6$ & $5 / 21-5 / 27$ & $4 / 30-5 / 6$ \\
\hline 2002 & $4 / 16-4 / 22$ & $4 / 30-5 / 6$ & $5 / 21-5 / 27$ & $4 / 30-5 / 6$ & $4 / 30-5 / 6$ & $4 / 30-5 / 6$ & $5 / 21-5 / 27$ & $4 / 30-5 / 6$ \\
\hline 2003 & $4 / 9-4 / 15$ & $4 / 30-5 / 6$ & $5 / 21-5 / 27$ & $5 / 14-5 / 20$ & $4 / 30-5 / 6$ & $5 / 14-5 / 20$ & $5 / 28-6 / 3$ & $5 / 14-5 / 20$ \\
\hline 2004 & $4 / 16-4 / 22$ & $4 / 30-5 / 6$ & $5 / 14-5 / 20$ & $5 / 7-5 / 13$ & $4 / 30-5 / 6$ & $5 / 7-5 / 13$ & $5 / 14-5 / 20$ & $5 / 14-5 / 20$ \\
\hline 2005 & $3 / 26-4 / 1$ & $4 / 23-4 / 29$ & $5 / 7-5 / 13$ & $5 / 7-5 / 13$ & $4 / 30-5 / 6$ & $4 / 30-5 / 6$ & $5 / 14-5 / 20$ & $4 / 30-5 / 6$ \\
\hline 2006 & $4 / 16-4 / 22$ & $5 / 7-5 / 13$ & $5 / 21-5 / 27$ & $5 / 14-5 / 20$ & $4 / 23-4 / 29$ & $5 / 7-5 / 13$ & $5 / 21-5 / 27$ & $5 / 14-5 / 20$ \\
\hline Mean & $4 / 2-4 / 8$ & $4 / 30-5 / 6$ & $5 / 21-5 / 27$ & $5 / 7-5 / 13$ & $4 / 23-4 / 29$ & $5 / 7-5 / 13$ & $5 / 21-5 / 27$ & $5 / 7-5 / 13$ \\
\hline
\end{tabular}

Appendix Table A-2. Week of $10^{\text {th }}, 50^{\text {th }}$, and $90^{\text {th }}$ percentiles of spring Chinook salmon emigrating from the Umatilla River, 19952006.

\begin{tabular}{|c|c|c|c|c|c|c|c|c|}
\hline \multirow[b]{2}{*}{$\begin{array}{l}\text { Outmigration } \\
\text { year }\end{array}$} & \multicolumn{4}{|c|}{ Natural spring Chinook salmon } & \multicolumn{4}{|c|}{ Hatchery spring Chinook salmon } \\
\hline & $\begin{array}{c}10 \% \\
\text { emigration }\end{array}$ & $\begin{array}{c}50 \% \\
\text { emigration }\end{array}$ & $\begin{array}{c}90 \% \\
\text { emigration }\end{array}$ & $\begin{array}{c}\text { Peak } \\
\text { emigration }\end{array}$ & $\begin{array}{l}10 \% \\
\text { emigration }\end{array}$ & $\begin{array}{c}50 \% \\
\text { emigration } \\
\end{array}$ & $\begin{array}{c}90 \% \\
\text { emigration }\end{array}$ & $\begin{array}{c}\text { Peak } \\
\text { emigration }\end{array}$ \\
\hline 1995 & $12 / 3-12 / 9$ & $2 / 26-3 / 4$ & $4 / 16-4 / 22$ & $12 / 3-12 / 9$ & $12 / 3-12 / 9$ & $4 / 9-4 / 15$ & $4 / 16-4 / 22$ & $4 / 16-4 / 22$ \\
\hline 1996 & $3 / 19-3 / 25$ & $4 / 2-4 / 8$ & $4 / 23-4 / 29$ & $4 / 2-4 / 8$ & $3 / 12-3 / 18$ & $3 / 12-3 / 18$ & $4 / 2-4 / 8$ & $3 / 12-3 / 18$ \\
\hline 1997 & $12 / 24-12 / 31$ & $1 / 15-1 / 21$ & $4 / 9-4 / 15$ & $1 / 15-1 / 21$ & $3 / 26-4 / 1$ & $3 / 26-4 / 1$ & $4 / 16-4 / 22$ & $3 / 26-4 / 1$ \\
\hline 1998 & $4 / 9-4 / 15$ & $4 / 23-4 / 29$ & $4 / 30-5 / 6$ & $4 / 23-4 / 29$ & $4 / 16-4 / 22$ & $4 / 16-4 / 22$ & $4 / 30-5 / 6$ & $4 / 16-4 / 22$ \\
\hline 1999 & $3 / 5-3 / 11$ & $4 / 2-4 / 8$ & $4 / 30-5 / 6$ & $3 / 12-3 / 18$ & $3 / 5-3 / 11$ & $3 / 5-3 / 11$ & $3 / 5-3 / 11$ & $3 / 5-3 / 11$ \\
\hline 2000 & $4 / 23-4 / 29$ & $4 / 30-5 / 6$ & $4 / 30-5 / 6$ & $4 / 30-5 / 6$ & $4 / 23-4 / 29$ & $4 / 30-5 / 6$ & $4 / 30-5 / 6$ & $4 / 30-5 / 6$ \\
\hline 2001 & $3 / 12-3 / 18$ & $4 / 9-4 / 15$ & $5 / 14-5 / 20$ & $5 / 14-5 / 20$ & $3 / 12-3 / 18$ & $4 / 16-4 / 22$ & $5 / 7-5 / 13$ & $4 / 23-4 / 29$ \\
\hline 2002 & $3 / 12-3 / 18$ & $4 / 30-5 / 6$ & $5 / 14-5 / 20$ & $4 / 30-5 / 6$ & $3 / 12-3 / 18$ & $4 / 16-4 / 22$ & $4 / 30-5 / 6$ & $4 / 30-5 / 6$ \\
\hline 2003 & $3 / 5-3 / 11$ & $4 / 16-4 / 22$ & $5 / 7-5 / 13$ & $4 / 16-4 / 22$ & $3 / 5-3 / 11$ & $4 / 23-4 / 29$ & $4 / 30-5 / 6$ & $4 / 23-4 / 29$ \\
\hline 2004 & $4 / 2-4 / 8$ & $4 / 16-4 / 22$ & $4 / 30-5 / 6$ & $4 / 16-4 / 22$ & $4 / 9-4 / 15$ & $4 / 16-4 / 22$ & $4 / 30-5 / 6$ & $4 / 16-4 / 22$ \\
\hline 2005 & $3 / 26-4 / 1$ & $4 / 9-4 / 15$ & $4 / 23-4 / 29$ & $4 / 16-4 / 22$ & $3 / 12-3 / 18$ & $3 / 26-4 / 1$ & $4 / 16-4 / 22$ & $3 / 26-4 / 1$ \\
\hline 2006 & $3 / 5-3 / 11$ & $4 / 23-4 / 29$ & $5 / 7-5 / 13$ & $4 / 23-4 / 29$ & $2 / 26-3 / 4$ & $4 / 16-4 / 22$ & $5 / 7-5 / 13$ & $5 / 7-5 / 13$ \\
\hline Mean & $2 / 26-3 / 4$ & $4 / 16-4 / 22$ & $4 / 30-5 / 6$ & $4 / 16-4 / 22$ & $3 / 5-3 / 11$ & $4 / 16-4 / 22$ & $4 / 30-5 / 6$ & $4 / 9-4 / 15$ \\
\hline
\end{tabular}


Appendix Table A-3. Week of $10^{\text {th }}, 50^{\text {th }}$, and $90^{\text {th }}$ percentiles of fall Chinook salmon emigrating from the Umatilla River, $1995-2006$.

\begin{tabular}{|c|c|c|c|c|c|c|c|c|}
\hline \multirow[b]{2}{*}{$\begin{array}{l}\text { Outmigration } \\
\text { year }\end{array}$} & \multicolumn{4}{|c|}{ Natural fall Chinook salmon } & \multicolumn{4}{|c|}{ Hatchery fall Chinook salmon } \\
\hline & $\begin{array}{c}10 \% \\
\text { emigration }\end{array}$ & $\begin{array}{c}50 \% \\
\text { emigration } \\
\end{array}$ & $\begin{array}{c}90 \% \\
\text { emigration }\end{array}$ & $\begin{array}{c}\text { Peak } \\
\text { emigration }\end{array}$ & $\begin{array}{c}10 \% \\
\text { emigration }\end{array}$ & $\begin{array}{c}50 \% \\
\text { emigration }\end{array}$ & $\begin{array}{c}90 \% \\
\text { emigration }\end{array}$ & $\begin{array}{c}\text { Peak } \\
\text { emigration }\end{array}$ \\
\hline 1995 & $6 / 18-6 / 24$ & $6 / 18-6 / 24$ & $6 / 25-7 / 1$ & $6 / 25-7 / 1$ & $5 / 21-5 / 27$ & $5 / 21-5 / 27$ & $6 / 4-6 / 10$ & $5 / 21-5 / 27$ \\
\hline 1996 & $5 / 14-5 / 20$ & $5 / 28-6 / 3$ & $6 / 11-6 / 17$ & $5 / 14-5 / 20$ & $6 / 4-6 / 10$ & $6 / 4-6 / 10$ & $6 / 4-6 / 10$ & $6 / 4-6 / 10$ \\
\hline 1997 & $5 / 28-6 / 3$ & $6 / 11-6 / 17$ & $6 / 18-6 / 24$ & $6 / 11-6 / 17$ & $5 / 28-6 / 3$ & $6 / 4-6 / 10$ & $6 / 18-6 / 24$ & $5 / 28-6 / 3$ \\
\hline 1998 & $6 / 4-6 / 10$ & $6 / 11-6 / 17$ & $6 / 25-7 / 1$ & $6 / 11-6 / 17$ & $5 / 28-6 / 3$ & $6 / 4-6 / 10$ & $6 / 11-6 / 17$ & $6 / 4-6 / 10$ \\
\hline 1999 & $4 / 30-5 / 6$ & $6 / 11-6 / 17$ & $6 / 25-7 / 1$ & $6 / 11-6 / 17$ & $6 / 11-6 / 17$ & $6 / 18-6 / 24$ & $6 / 18-6 / 24$ & $6 / 11-6 / 17$ \\
\hline 2000 & $5 / 21-5 / 27$ & $6 / 4-6 / 10$ & $6 / 18-6 / 24$ & $6 / 4-6 / 10$ & $5 / 21-5 / 27$ & $5 / 28-6 / 3$ & $6 / 4-6 / 10$ & $5 / 21-5 / 27$ \\
\hline 2001 & $5 / 21-5 / 27$ & $6 / 11-6 / 17$ & $7 / 2-7 / 8$ & $6 / 4-6 / 10$ & $5 / 21-5 / 27$ & $5 / 28-6 / 3$ & $5 / 28-6 / 3$ & $5 / 28-6 / 3$ \\
\hline 2002 & $4 / 30-5 / 6$ & $6 / 4-6 / 10$ & $6 / 25-7 / 1$ & $4 / 30-5 / 6$ & $5 / 21-5 / 27$ & $5 / 21-5 / 27$ & $6 / 4-6 / 10$ & $5 / 21-5 / 27$ \\
\hline 2003 & $5 / 21-5 / 27$ & $5 / 28-6 / 3$ & $6 / 4-6 / 10$ & $5 / 28-6 / 3$ & $5 / 21-5 / 27$ & $5 / 21-5 / 27$ & $5 / 28-6 / 3$ & $5 / 21-5 / 27$ \\
\hline 2004 & $5 / 28-6 / 3$ & $6 / 11-6 / 17$ & $6 / 18-6 / 24$ & $6 / 4-6 / 10$ & $5 / 28-6 / 3$ & $5 / 28-6 / 3$ & $6 / 4-6 / 10$ & $5 / 28-6 / 3$ \\
\hline 2005 & $5 / 7-5 / 13$ & $5 / 28-6 / 3$ & $6 / 18-6 / 24$ & $5 / 28-6 / 3$ & $5 / 14-5 / 20$ & $5 / 14-5 / 20$ & $5 / 21-5 / 27$ & $5 / 14-5 / 20$ \\
\hline 2006 & $5 / 21-5 / 27$ & $6 / 11-6 / 17$ & $6 / 18-6 / 24$ & $6 / 4-6 / 10$ & $5 / 21-5 / 27$ & $5 / 28-6 / 3$ & $6 / 4-6 / 10$ & $5 / 28-6 / 3$ \\
\hline Mean & $5 / 21-5 / 27$ & $6 / 11-6 / 17$ & $6 / 18-6 / 24$ & $6 / 4-6 / 10$ & $5 / 21-5 / 27$ & $5 / 28-6 / 3$ & $6 / 11-6 / 17$ & $5 / 28-6 / 3$ \\
\hline
\end{tabular}


Appendix Table A-4. Species-specific trap efficiency estimates for the juvenile bypass/trapping facility at TMFD, 2004-2006 (ND = Not determined).

\begin{tabular}{|c|c|c|c|c|c|c|c|c|c|c|c|c|c|c|c|c|}
\hline \multirow{2}{*}{ Year } & \multicolumn{3}{|c|}{ February } & \multicolumn{3}{|c|}{ March } & \multicolumn{3}{|c|}{ April } & \multicolumn{3}{|c|}{ May } & \multicolumn{3}{|c|}{ June } & \multirow{2}{*}{$\begin{array}{l}\text { Total } \\
\text { Mean } \\
\end{array}$} \\
\hline & Min & Max & Mean & Min & Max & Mean & Min & Max & Mean & Min & Max & Mean & Min & Max & Mean & \\
\hline & & & & & & & & & & & & & & & & \\
\hline \multicolumn{17}{|c|}{ Hatchery Yearling Spring Chinook Salmon } \\
\hline 2004 & ND & ND & ND & 1.7 & 43.3 & 15.6 & 8.3 & 81.7 & 53.0 & 23.1 & 76.7 & 55.1 & ND & ND & ND & 46.0 \\
\hline 2005 & ND & ND & ND & 2.0 & 53.3 & 22.2 & 38.3 & 68.8 & 53.8 & ND & ND & ND & ND & ND & ND & 38.0 \\
\hline & & & & & & & & & & & & & & & & \\
\hline \multicolumn{17}{|c|}{ Hatchery Yearling Fall Chinook Salmon } \\
\hline 2004 & ND & ND & ND & 10.0 & 55.2 & 27.4 & 24.1 & 76.7 & 55.1 & 8.6 & 65.0 & 41.2 & ND & ND & ND & 46.7 \\
\hline 2005 & 20.0 & 20.0 & 20.0 & 10.8 & 30.8 & 20.6 & 40.0 & 67.5 & 59.7 & ND & ND & ND & ND & ND & ND & 37.9 \\
\hline & & & & & & & & & & & & & & & & \\
\hline \multicolumn{17}{|c|}{ Hatchery Subyearling Fall Chinook Salmon } \\
\hline 2004 & ND & ND & ND & ND & ND & ND & ND & ND & ND & ND & ND & ND & 15.0 & 65.0 & 29.0 & 39.2 \\
\hline 2005 & ND & ND & ND & ND & ND & ND & ND & ND & ND & 22.0 & 51.0 & 36.5 & 23.4 & 56.0 & 39.7 & 38.1 \\
\hline 2006 & ND & ND & ND & ND & ND & ND & ND & ND & ND & 38.0 & 38.0 & 38.0 & ND & ND & ND & 38.0 \\
\hline & & & & & & & & & & & & & & & & \\
\hline \multicolumn{17}{|c|}{ Hatchery Coho Salmon } \\
\hline 2004 & ND & ND & ND & 5.0 & 6.7 & 6.1 & 24.0 & 41.7 & 32.0 & 11.7 & 62.7 & 42.5 & ND & ND & ND & 31.7 \\
\hline 2005 & 11.0 & 11.0 & 11.0 & 8.0 & 28.0 & 18.0 & 24.1 & 26.7 & 25.2 & 15.8 & 46.2 & 31.0 & ND & ND & ND & 23.1 \\
\hline & & & & & & & & & & & & & & & & \\
\hline \multicolumn{17}{|c|}{ Hatchery Summer Steelhead } \\
\hline 2004 & ND & ND & ND & ND & ND & ND & 50.0 & 50.0 & 50.0 & 21.9 & 53.3 & 31.5 & ND & ND & ND & 34.1 \\
\hline 2005 & ND & ND & ND & ND & ND & ND & ND & ND & ND & 17.0 & 41.6 & 26.2 & ND & ND & ND & 26.2 \\
\hline 2006 & ND & ND & ND & ND & ND & ND & 46.3 & 46.3 & 46.3 & 16.0 & 45.8 & 26.9 & 14.3 & 14.3 & 14.3 & 27.9 \\
\hline & & & & & & & & & & & & & & & & \\
\hline \multicolumn{17}{|c|}{ Natural Spring Salmon } \\
\hline 2004 & ND & ND & ND & 23.1 & 23.1 & 23.1 & 10.0 & 54.5 & 30.9 & 7.1 & 75.0 & 45.2 & ND & ND & ND & 35.9 \\
\hline 2005 & 0.0 & 13.8 & 6.8 & 17.6 & 17.6 & 17.6 & 50.0 & 63.4 & 59.3 & 68.3 & 68.3 & 68.3 & ND & ND & ND & 38.2 \\
\hline 2006 & 23.3 & 23.3 & 23.3 & 10.7 & 36.7 & 26.9 & 48.1 & 52.4 & 50.2 & 71.4 & 72.7 & 72.1 & ND & ND & ND & 43.6 \\
\hline & & & & & & & & & & & & & & & & \\
\hline \multicolumn{17}{|c|}{ Natural Subyearling Fall Chinook Salmon } \\
\hline 2004 & ND & ND & ND & ND & ND & ND & ND & ND & ND & ND & ND & ND & 3.1 & 51.2 & 22.6 & 22.6 \\
\hline 2005 & ND & ND & ND & ND & ND & ND & ND & ND & ND & 40.0 & 72.4 & 56.2 & 22.2 & 37.0 & 29.4 & 40.1 \\
\hline 2006 & ND & ND & ND & ND & ND & ND & ND & ND & ND & ND & ND & ND & 24.2 & 43.1 & 32.2 & 32.2 \\
\hline & & & & & & & & & & & & & & & & \\
\hline \multicolumn{17}{|c|}{ Natural Summer Steelhead } \\
\hline 2004 & ND & ND & ND & 44.0 & 44.0 & 44.0 & 47.8 & 49.9 & 48.7 & 26.9 & 40.0 & 34.2 & ND & ND & ND & 40.1 \\
\hline 2005 & 25.0 & 25.0 & 25.0 & 8.3 & 16.7 & 11.4 & 39.0 & 54.0 & 44.1 & 14.1 & 47.1 & 31.5 & ND & ND & ND & 28.6 \\
\hline 2006 & 26.3 & 33.3 & 29.8 & 31.8 & 40.0 & 35.9 & 51.3 & 61.0 & 56.2 & 27.8 & 42.6 & 36.7 & 29.2 & 29.2 & 29.2 & 38.1 \\
\hline & & & & & & & & & & & & & & & & \\
\hline & & & & & & & & & & & & & & & & \\
\hline
\end{tabular}


Appendix Table A-5. Egg-to-smolt survival of naturally spawning summer steelhead in the Umatilla River, BY 1993-2004.

\begin{tabular}{ccccccc}
\hline $\begin{array}{c}\text { Brood } \\
\text { Year }\end{array}$ & Total & $\begin{array}{c}\text { Female Escapement }^{\mathrm{a}} \\
\text { S1 }\end{array}$ & S2 & $\begin{array}{c}\text { Number }^{\mathrm{b}} \\
\text { of eggs }\end{array}$ & $\begin{array}{c}\text { Number }^{\mathrm{c}} \\
\text { of smolts }^{2}\end{array}$ & $\begin{array}{c}\text { Egg to } \\
\text { smolt survival (\%) }\end{array}$ \\
\hline 1993 & 1102 & 522 & 580 & 6116187 & 52,010 & 0.85 \\
1994 & 806 & 432 & 374 & 4323435 & 68,162 & 1.58 \\
1995 & 866 & 404 & 462 & 4824913 & 26,295 & 0.54 \\
1996 & 1205 & 881 & 324 & 5761557 & 59,278 & 1.03 \\
1997 & 1330 & 768 & 562 & 6969537 & 46,532 & 0.67 \\
1998 & 996 & 559 & 437 & 5267468 & 83,144 & 1.58 \\
1999 & 1082 & 578 & 504 & 5809681 & 32,573 & 0.56 \\
2000 & 1614 & 1,327 & 287 & 7278281 & 73,177 & 1.01 \\
2001 & 2293 & 1,118 & 1175 & 12631251 & 26,813 & 0.21 \\
2002 & 2741 & 1,767 & 974 & 13813433 & 37,559 & 0.27 \\
$2003^{\mathrm{d}}$ & 1937 & 561 & 1376 & 11815091 & 56,855 & 0.48 \\
$2004^{\mathrm{d}}$ & 1589 & 1,290 & 299 & 7214651 & 31,423 & 0.44 \\
& & & & & & \\
Mean $^{\mathrm{e}}$ & 1463 & 851 & 613 & 7652124 & $49,485^{\mathrm{d}}$ & 0.77 \\
\hline
\end{tabular}

${ }^{a}$ Total no. females available to spawn (hatchery and natural origin).

${ }^{b}$ Mean fecundity of natural females estimated as 3,979 for S1 and 6,965 for S2 fish.

${ }^{c}$ Smolt yield was adjusted for age structure.

${ }^{d}$ Dataset incomplete. Estimates do no include age 3 and 4 emigrants.

${ }^{e}$ Includes BY 1993-2004

Appendix Table A-6. Smolt-to-adult return rate (\%) of natural summer steelhead in the Umatilla River, 1995-2006.

\begin{tabular}{|c|c|c|c|c|c|c|}
\hline \multirow[b]{2}{*}{ Outmigration year } & \multirow{2}{*}{$\begin{array}{l}\text { Smolt } \\
\text { yield }\end{array}$} & \multicolumn{4}{|c|}{ Number of returns to TMFD ${ }^{\mathrm{a}}$} & \multirow{2}{*}{$\begin{array}{l}\text { Smolt-to-adult } \\
\text { return rate }(\%)\end{array}$} \\
\hline & & $\mathrm{S} 1$ & $\mathrm{~S} 2$ & S3 & Total & \\
\hline 1995 & 54,361 & 614 & 223 & 0 & 837 & 1.54 \\
\hline 1996 & 73,361 & 614 & 426 & 0 & 1,040 & 1.42 \\
\hline 1997 & 22,221 & 709 & 282 & 34 & 1,025 & 4.61 \\
\hline 1998 & 59,182 & 1,858 & 1,293 & 0 & 3,151 & 5.32 \\
\hline 1999 & 46,530 & 1,244 & 979 & 72 & 2,295 & 4.93 \\
\hline 2000 & 81,759 & 2,642 & 1,373 & 0 & 4,015 & 4.91 \\
\hline $2001^{\mathrm{b}}$ & 33,844 & 672 & 460 & 0 & 1,131 & 3.34 \\
\hline $2002^{\mathrm{b}}$ & 77,016 & 1,641 & 0 & 0 & 1,641 & 2.13 \\
\hline Mean $^{\mathrm{c}}$ & 50,217 & 1,249 & 630 & 13 & 1,892 & 3.53 \\
\hline
\end{tabular}

${ }^{a}$ Partitioned by age structure (S1, S2 and\& S3) using adult scale analysis.

${ }^{b}$ Dataset incomplete. Estimates do not include adult return data for 2004 and 2005.

${ }^{c}$ Includes smolt outmigration years 1995-2002. 


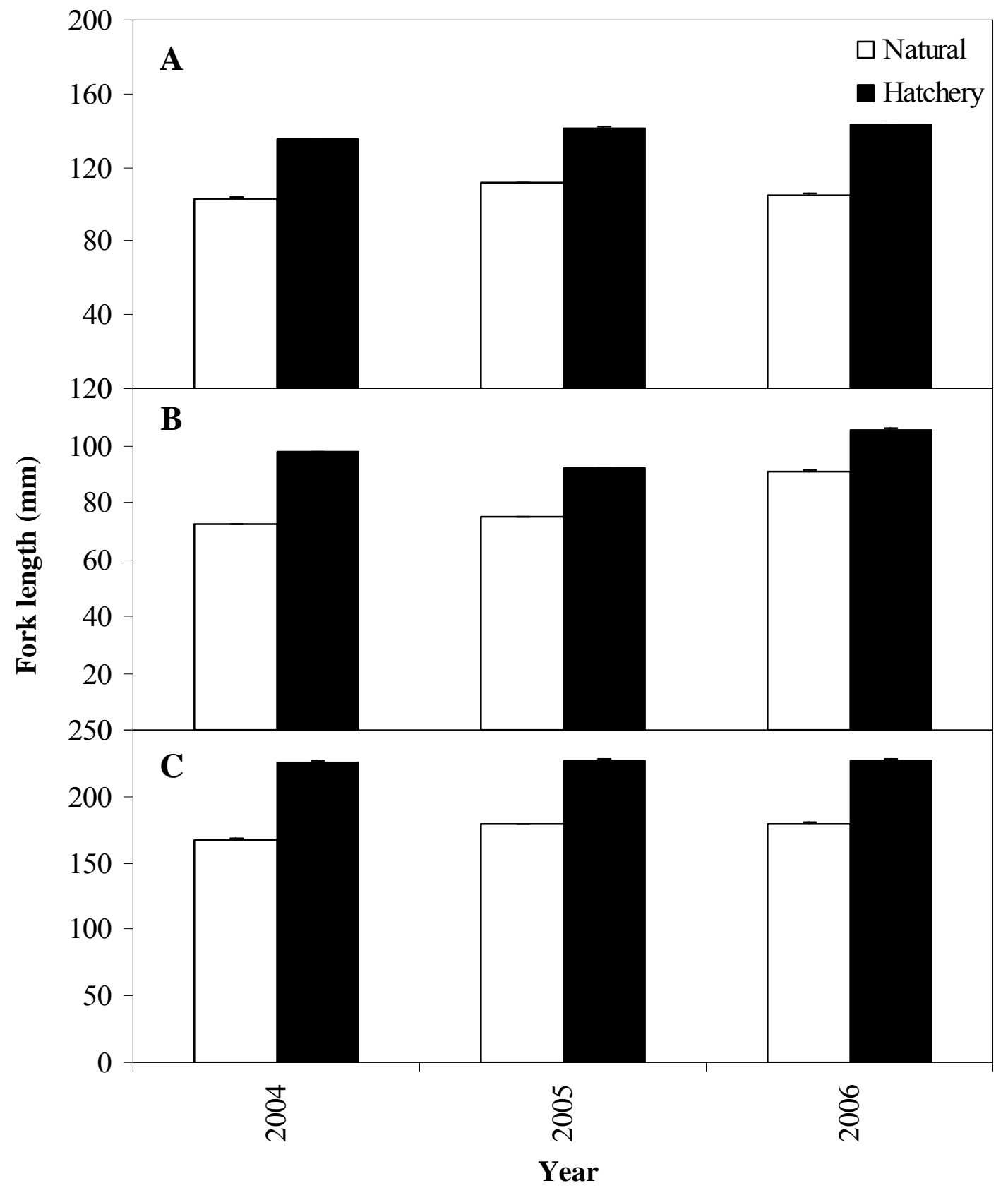

Appendix Figure A-1. Comparison of mean annual fork length $(+1 \mathrm{SE})$ for natural and hatchery spring Chinook salmon (A), fall Chinook salmon (B), and summer steelhead (C), outmigration years 2004-2006. All years were significantly different $(P<0.05)$. 


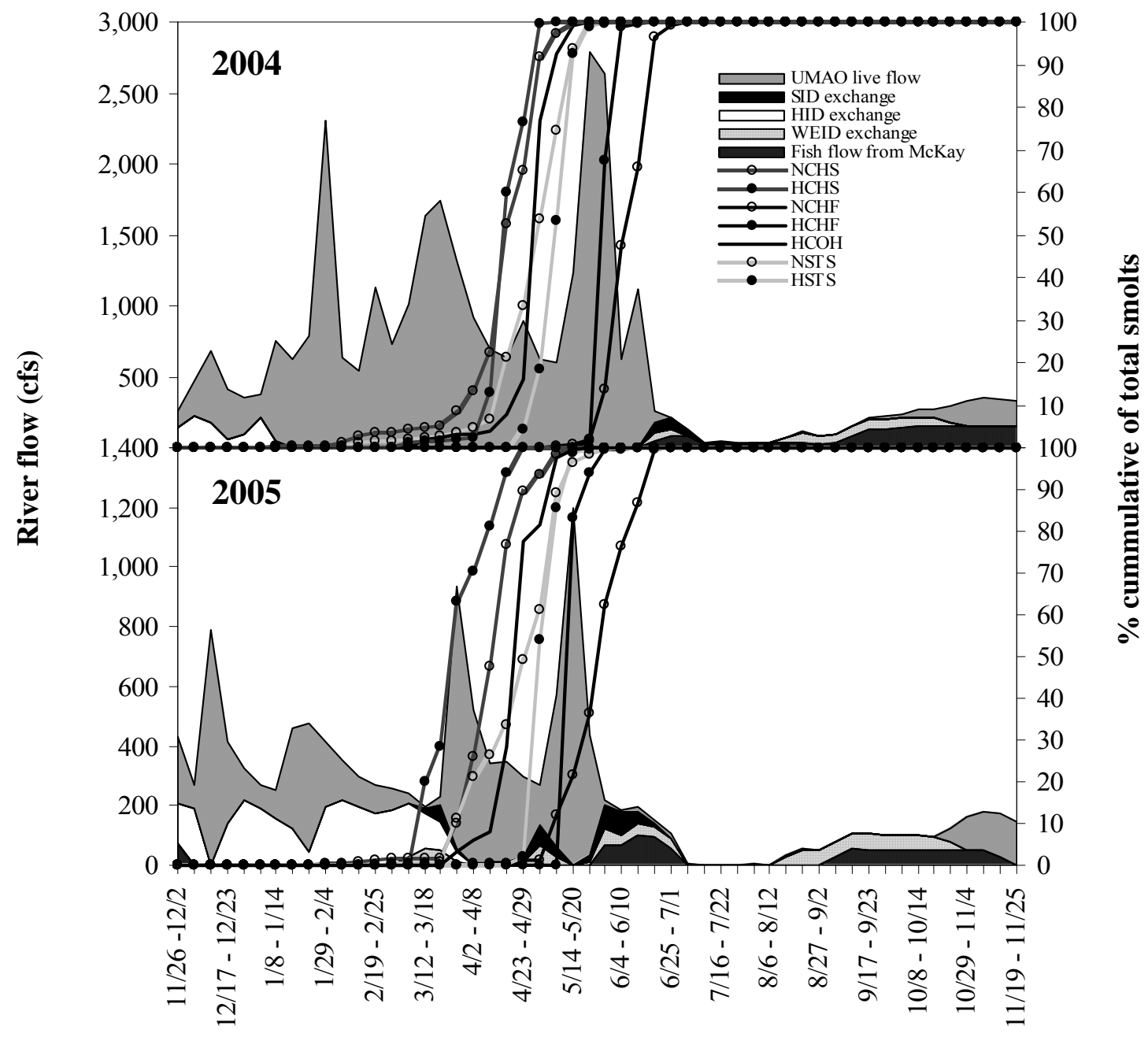

Week

Appendix Figure A-2. Weekly river flow by proportion of source (water exchange, stored water, or live flow) and cumulative emigration timing of natural (NCHS) and hatchery (HCHS) spring Chinook salmon, natural (NCHF) and hatchery (HCHF0) subyearling fall Chinook salmon, hatchery $(\mathrm{HCOH})$ coho salmon, and natural (NSTS) and hatchery (HSTS) summer steelhead in the Umatilla River, 2004-2005. 
APPENDIX B

Three Mile Falls Dam

Adult Ladder Detector

Design Plans and Specifications 


\section{Appendix B-1 Three Mile Falls Dam Design Description Narrative}

\section{Demolition Plan}

The demolition work for this project consists of removing two existing concrete weirs specifically the second and fourth weirs downstream from the fish viewing window. The weirs will be removed using a concrete saw capable of cutting flush with the walls and the floor of the ladder. The concrete weir pieces will then be lifted from the ladder after they have been sawed free.

When the weirs are removed, the remaining fish ladder structure will have reduced strength to resist the implied load related to the soil loading on the outside of the ladder wall to the east. The soil loading effectively imposes a bending moment on the floor slab of the fish ladder. A note is included on the demolition plan requiring the contractor to either remove the soil load by excavation or to shore the east ladder wall temporarily. Once the floor of the ladder is repaired and the pre-cast concrete weirs and cast-in-place concrete cap beam are in place, the new weirs including the cap beam will make the composite fish ladder structure considerably stronger (with regard to resisting the soil load) than the original structure

During operation, the PIT tag antennas sit inside 10 inch deep cavities in the floor of the fish ladder. The electro-magnetic field (EMF) emitted by the antenna will intersect with the floor slab. To prevent the existing steel reinforcing in the floor slab from interfering with the antenna's EMF, the floor of the ladder will be saw cut to remove existing steel reinforcing within the floor within a three-foot radius of the antennas. This distance was stipulated at the initial site visit and technically extends to and beyond the nearest existing ladder wall adjacent to the weir. In this area the concrete removal will end where the floor meets the existing ladder wall. The three foot radius from the PIT tag antenna has been laid out and used to define a rectangular area for concrete removal. The perimeter of the concrete removal area will be saw cut without overcutting at the corners. This will result in more structurally integrity at the reentrant corner of the existing concrete compared to removal where over-cutting at the corners is allowed.

Previous PIT tag projects have revealed that nearby metal grading can be a source of noise for the PIT tag antenna tag detection. Apparently, vibrations, wind, and miscellaneous transient loads on the grating create conditions where electrical contacts are made and then broken repeatedly. If these contacts change the resistance of or result in a new circuit to ground, the EMF field may be significantly affected by the phenomena. To prevent this from occurring at the Three Mile Falls project, we will require the contractor to remove some of the existing steel grating near the antennas and replace it with non-conductive fiberglass grating.

Field photos taken at the project show an existing structural support running longitudinal with the ladder and supporting the walkway grating at mid-span. Unfortunately, there are no as-built drawings showing this member. This member presently passes over the top of the existing weirs. 
This member will need to be modified during construction to accommodate the two new cast-inplace cap beams which will have a sloped finish surface matching the sloped surface of the existing grating. Presumably a section of the beam will be cut out in the field with a cutting torch and a connection to the new CIP cap beam made at the proper location. A detail of this connection is included in the contract drawings with warnig to the contractor that the size of the existing member is not known and the detail should be checked closely to assure that it is viable.

\section{Floor of Fish Ladder}

To simplify the construction of the PIT tag antennas, the sloped floor of the fish ladder will be modified slightly in the immediate vicinity of the antenna to allow for a more uniform and orthogonal antenna geometry. The differential between the original ladder floor and the modified floor is on the order of 1.75 inches.

$1 / 4 " \times 3 "$ x 2'-8" Fibergrate pultruded fiberglass plate will be used to control the size of the gap between the in-place antenna and the opening in the floor of the fish ladder. The plate will be field trimmed/installed to allow the screws to be located as required to secure the plate such that a $1 / 8$ " gap is provided.

The antenna will bear on two blocks of HDPE which will secured to the bottom of the cavity in the floor of the fish ladder. HDPE can be purchased as 1" x 2" bar from McMaster-Carr.

HDPE blocks upstream and downstream of the antenna will also lock the lower end of the antenna in place so that it does not vibrate as the water flows through the opening in the antenna.

\section{Recess in Floor}

Recesses in the floor of the fish ladder were not utilized at the Ice Harbor Dam and Lower Granite Dam PIT Tag projects. The recesses at Three Mile Falls Dam are necessary so that the invert of the antenna opening (the top of the bottom horizontal leg of the antenna) matches the existing slot geometry.

Since the antenna physically intersects the floor of the ladder, a zone of intense EMF (emitted by the antenna) is projected into the concrete floor close to the antenna. For this reason, the steelreinforced floor must be removed and replaced with glass fiber reinforced polymer (GFRP) reinforced concrete. GFRP reinforcing bars are essentially fiberglass members with strengths and applications similar to steel reinforcing. To accommodate the specified depth at the recess in the floor, the floor of ladder is thickened from 12 inches to 1'-4'”. 


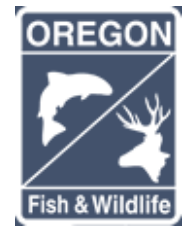

To prevent the antenna from effectively grinding against the concrete floor or being highcentered on a piece loose grit in the bottom of the recess, HDPE bearings are used on the bottom of the recess to protect the antenna by supporting it slightly above the floor. Similarly, HDPE bearings are used on the vertical surfaces upstream and downstream to support the portion of the antenna cantilevered below the fiberglass guides above the recess. The HDPE bearings can be machined as necessary to make the antenna plumb and true.

To minimize grit and debris that could accumulate in the recess, $1 / 4$ " thick fiberglass plate is used upstream and downstream from the antenna to minimize the gap between the concrete and the antenna.

\section{Precast Concrete Weir Segments}

The precast weir segments will be cast lying flat, presumably at the contractor's fabrication shop. The concrete specified in the drawings is low-slump 4,000 psi 28-day compressive strength concrete. The concrete properties are speced as follows and are based on typical quality concrete readily available locally: W/C ratio 0.45 max, ASTM C-33 aggregate grading number 57 or 67 , slump 3-5 inch, and entrained air at 5-6\%.

Using precast concrete rather than cast-in-place concrete was utilized very effectively for similar PIT tag work at Ice Harbor and Lower Granite Dams recently. The construction contractor, Knight Construction, reports that this was a very efficient and practical way to construct the weirs and was far superior to casting the walls in-place upright within the confines of the fish ladder.

The vertical reinforcing (vertical when the weirs are in the installed orientation) will be grade 60 steel conforming to ASTM 615. The horizontal reinforcing will be GFRP fiberglass. By having steel reinforcing in one direction and non-conductive GFRP reinforcing in the other, the reinforcing will not create conductive loops and will not have the ability to cause arcing between the horizontal and vertical reinforcing bars when they are exposed to the EMF of the antenna.

The precast weirs - specifically the vertical steel reinforcing - will be anchored to the floor of the ladder using \#6 hooks in the new concrete floor and \#6 dowels in the existing concrete floor. Lenton interlock couplers cast in the precast weir segments will tie the floor reinforcing to the new weir. (http://www.erico.com/products/InterLock.asp) This was the system used to secure the precast concrete segments at Lower Granite and Ice Harbor dams. Special requirements including testing for continuity to ground are stipulated on the drawings to prevent the steel reinforcing and $\# 6$ dowels from forming a circuit to ground with the existing fish ladder floor reinforcing.

The horizontal reinforcing in the precast weir segments will be \#4 GFRP reinforcing and is included in the design primarily for shrinkage and crack control. This GFRP reinforcing is designed in accordance with the GFRP manufacturer's guidance including lap lengths and bend 


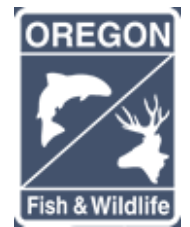

radii. The reinforcing will be made into the shapes (bends) required at the factory by shaping the fiberglass fibers and then injecting and curing the vinyl ester resin. Hughes Brothers - makers of Aslan FRP fiberglass rebar - has been consulted for the design of the reinforcing for this project.

The forms for new concrete will use $3 / 4$ " chamfers at exposed corners. This will make a neat corner and will prevent rough edges in the ladder that could de-scale fish.

The outboard edges of the weirs segments will include a $1 / 2$ " nominal gap to accommodate any irregularities or one-of-plumbness in the existing fish ladder wall and also allow the contractor to precisely place the weir segments while meeting the prescribed clearance \& tolerance at the opening between the pre-cast segments at the slot opening. The gap at the existing wall will ultimately be sealed using 1/2" closed-cell polyethylene backer rod and E6100 sealant. This sealant was specified by a Fisheries person that Tara White contacted. It is a fish-friendly nontoxic, non-sag sealant available from Eclectic Products that adheres to dry concrete and cures in 48-72 hours.

The precast weir segments will require a number of threaded inserts that will be utilized to secure the fiberglass antenna guides to the weir segments at the slot opening. The contractor will precisely and carefully drill holes in the forms and secure the threaded inserts (F-42 Ferrule Inserts) in the proper locations prior to casting the segments. The size and spacing of the inserts is based on accommodating the load case of a complete blockage of the fish ladder at the weir and the blocking material being completely supported by the antenna and or the guides. This is an extremely unlikely situation, so a low factor of safety was used to determine the size and spacing of the threaded inserts.

A number of \#6 dowels will be cast into the top edge of the precast weir segments to carry shear from the weir segments into the cast-in-place cap beam. The location of the dowels is detailed to prevent potential interference with the longitudinal reinforcing as well as with the end dowels in the cap beam.

\section{Weir Cap Beam}

The cast-in-place concrete cap beam on top of the new weirs will be very similar to the cap beams on top of the weirs at the recently constructed Ice Harbor Dam and Lower Granite Dam PIT Tag projects. These projects are mentioned in section 6.0 of the SOW. (Incidentally, these facilities are reported to be the most successful existing PIT tag detection systems administered by PSMFC.)

The cap beam above the modified weirs effectively protects the top leg of the antenna from impacts from floating debris during high water levels. It is conceivable that the replacement weirs could be constructed without the concrete cap beam on top, saving some costs, however the cap beam strengthens the new weirs considerably which will dampen potentially deleterious vibrations and, as mentioned above, the cap beam does provide protection to the antenna. If the 


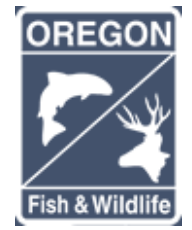

antenna is constructed so that the top leg of the antenna is beneath the cast-in-place cap beam, a removable section of grating will be fabricated with fiberglass angles and will be lowered into the antenna guide above the antenna. This assembly will provide protection from floating debris in the event that high water over-tops the antenna. The gap between the top of the antenna and the bottom of the cap beam is only a couple of inches. It is unlikely that this gap will pass debris of any size and it is presumed that water will rarely if ever reach this height in the ladder.

The top surface of the cap beam will match the existing steel grating elevation and will slope at $10 \mathrm{H}: 1 \mathrm{~V}$. As a minimum, the thickness of the concrete cap beam is as required to provide sufficient beam strength to resist the design head on the weir as well as concentrated dead and live load from the adjacent grating supports.

The top surface of the cap beam could be located immediately beneath the grating with the grating running over the cap beam. This would require more grating as well as openings in the grating to allow access to the antenna. With this in mind, the top of the proposed concrete cap beams will instead match the top of the existing grating.

The reinforcement of the cap beam is similar to the Ice Harbor and Lower Granite Dam projects with regular steel bars used for the longitudinal reinforcing and non-conducting GFRP reinforcing used for the transverse reinforcement (hoops). This prevents loops of conductive reinforcing from being created within the EMF field generated by the antenna. The longitudinal reinforcing is doweled into the existing fish ladder walls - which are 12" thick per the as-built drawings. The dowelled bars will be set in epoxy per the Hilti North American Product Technical Guide. Precautions will be taken to prevent the dowelled-in reinforcing from making contact with existing steel reinforcement. This will prevent possible arcing (and resulting EMF noise) at the contact between the new reinforcing and the existing reinforcing.

The cap beam will have an opening for the antenna similar to the Ice Harbor and clamps the antenna into the operating position since the antennas are slightly positively buoyant. This clamping effect will also prevent the antenna from moving or vibrating within the guides.

The 4-inch wide slots adjoining the opening for the antenna in the cap beam are intended to allow PSMFC to easily extract the antenna if the need arises without dewatering the ladder. PSMFC (or others) would drop a lifting strap down the 1" $\mathrm{x} 4$ " upstream slot, the flow will push the strap beneath the top leg of the antenna, and the strap would be snagged using a wire hook (ie. coat-hanger) and pulled up through the 3" x 4 " downstream slot.

The openings in the cap beams for the antennas do not require covers like what is in place at the Ice Harbor and Lower Granite Dam projects. Personnel do not need to be able to walk directly above the antenna since at Three Miles Falls Dam the entire ladder area is covered with grating. The opening as well as the cables from the antenna (a tripping hazard) is protected through the use of removable fiberglass handrail surrounding the opening.

\begin{tabular}{|l|rr|}
\hline Three Mile Falls Dam PIT Tag & & INCA \\
$\begin{array}{l}\text { Design Documentation Report } \\
\text { Final Submittal }\end{array}$ & & Page 62 \\
\hline
\end{tabular}


Appendix B-2

Construction Drawings

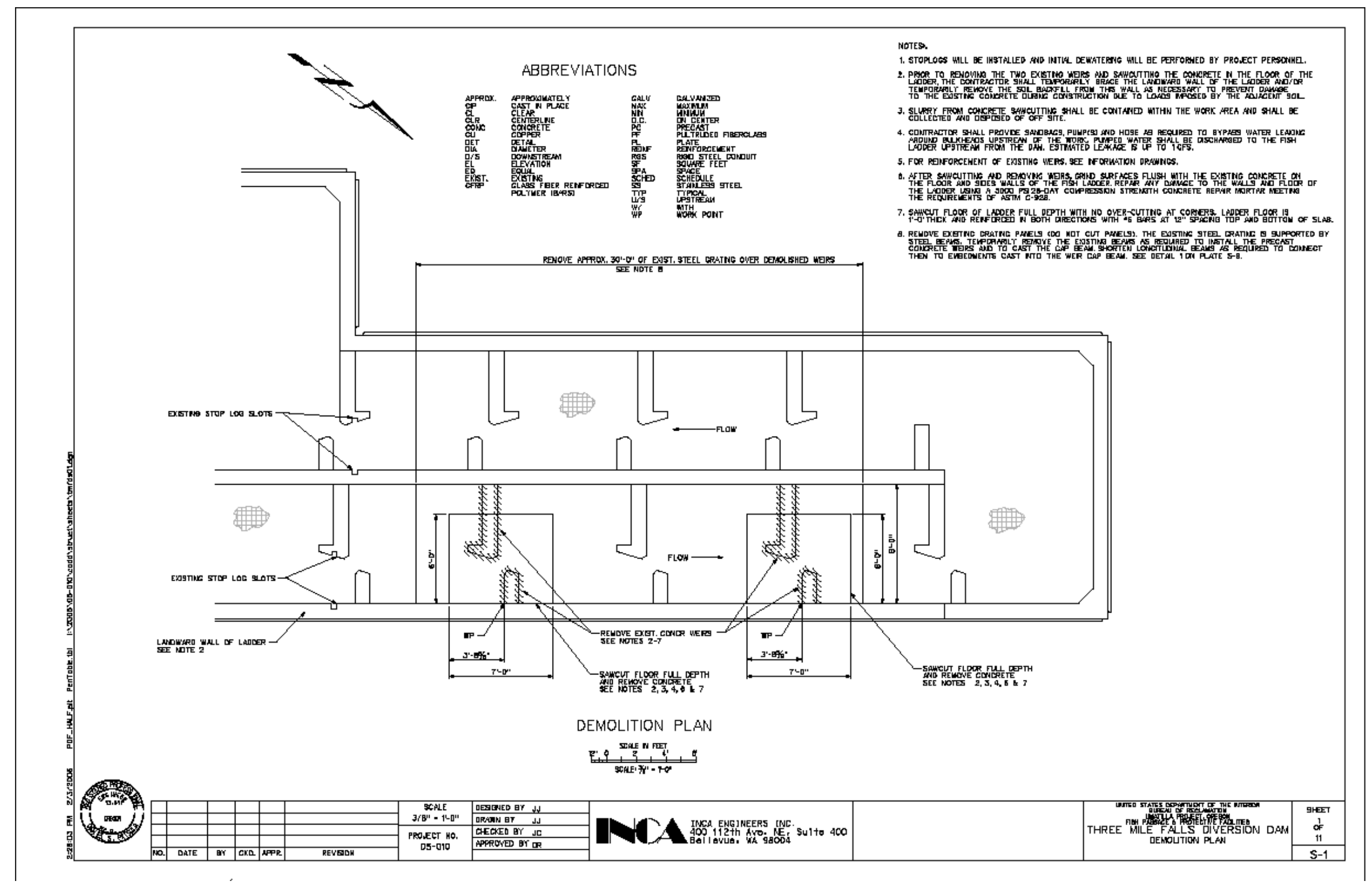


Appendix B-2

Construction Drawings

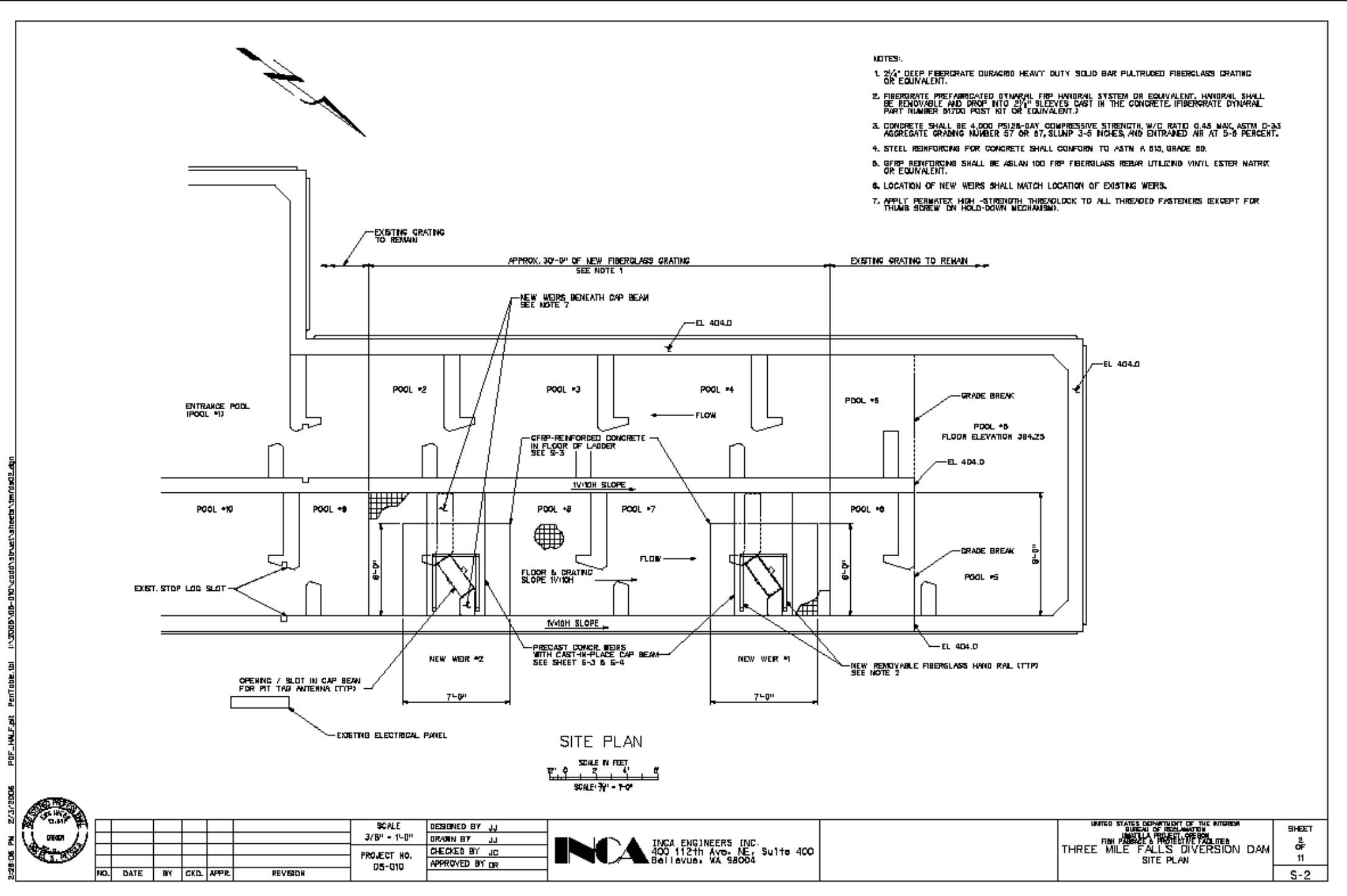


Appendix B-2

\section{Construction Drawings}

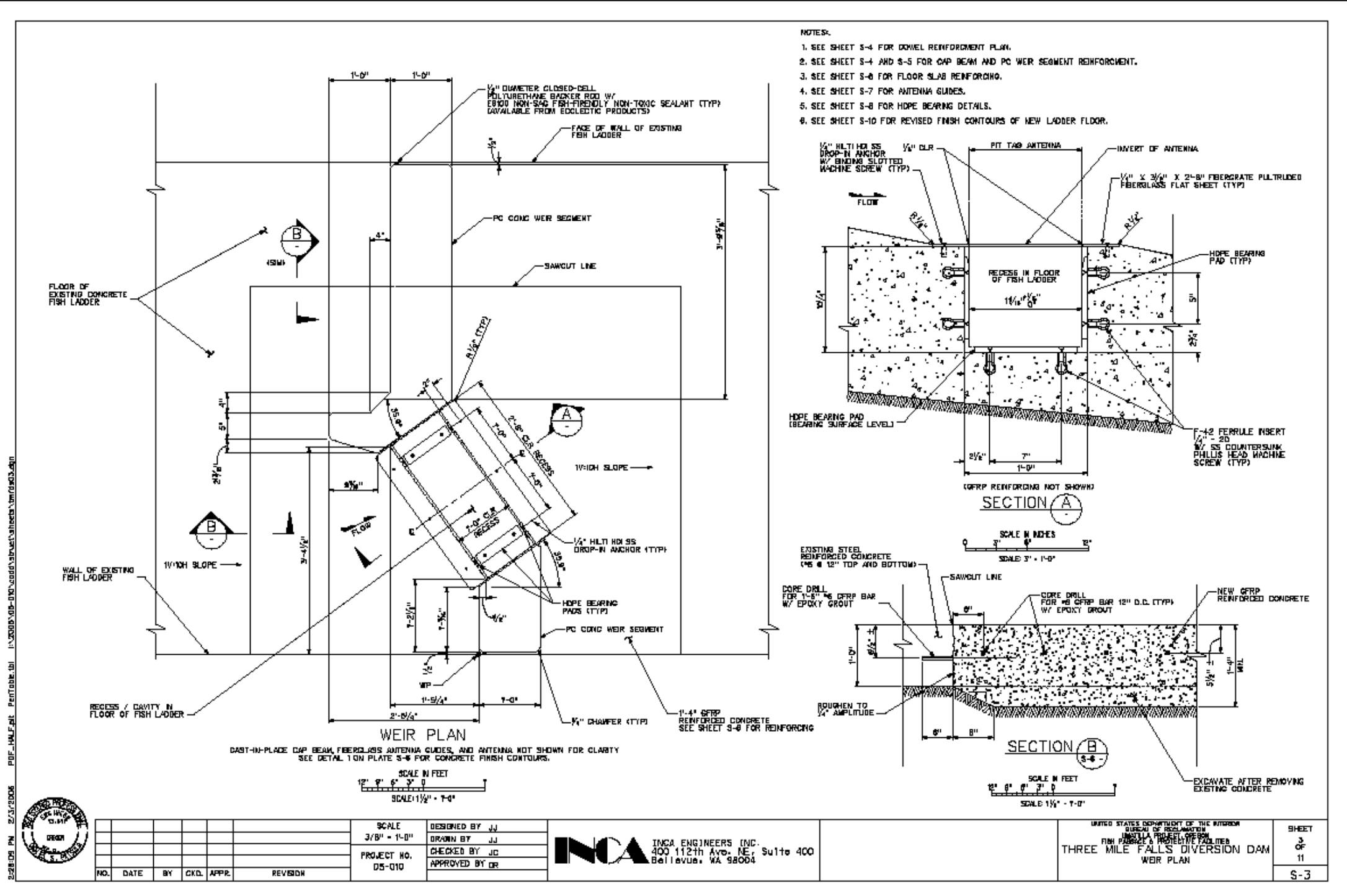


Appendix B-2

\section{Construction Drawings}

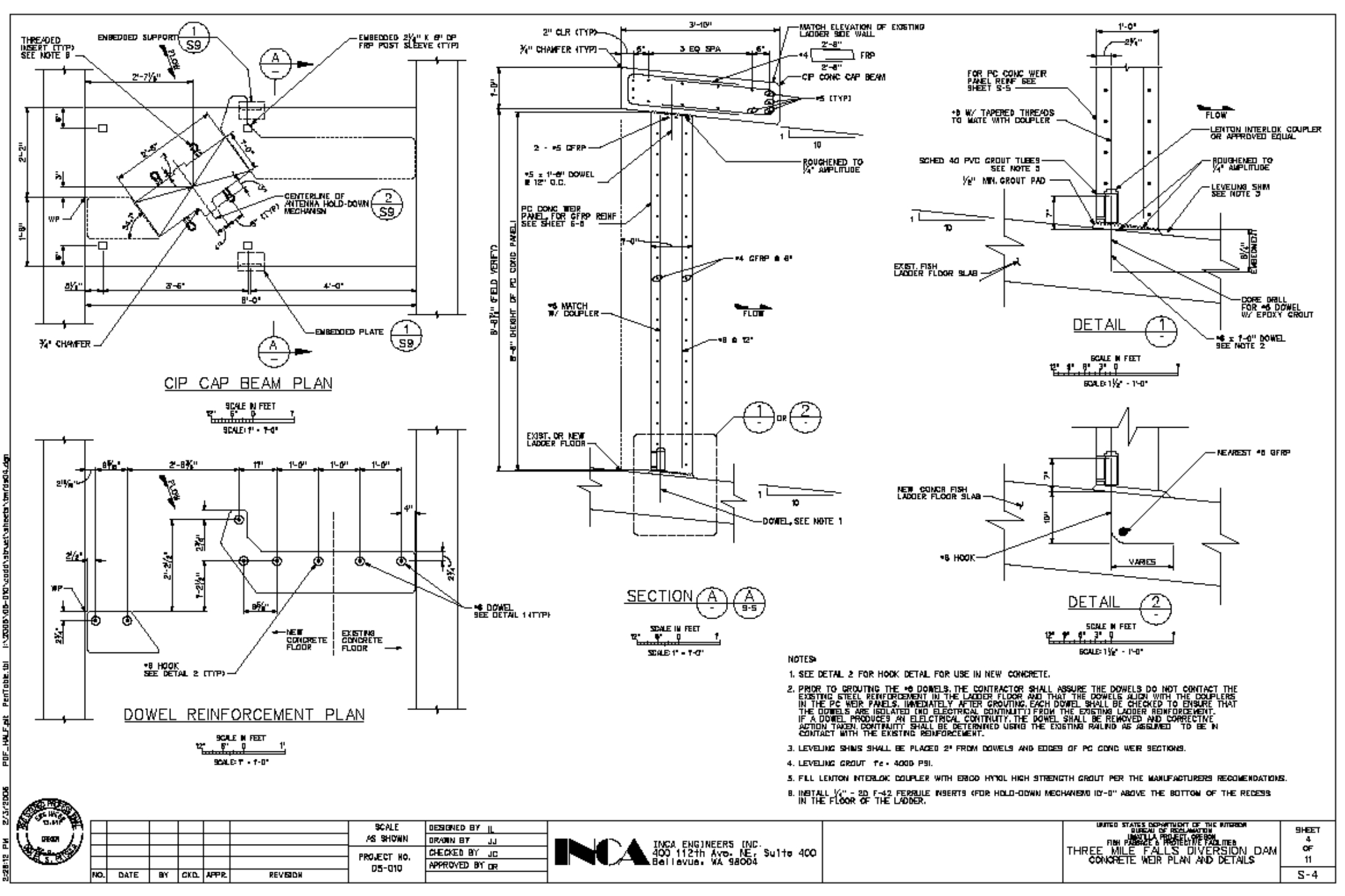


Appendix B-2

Construction Drawings

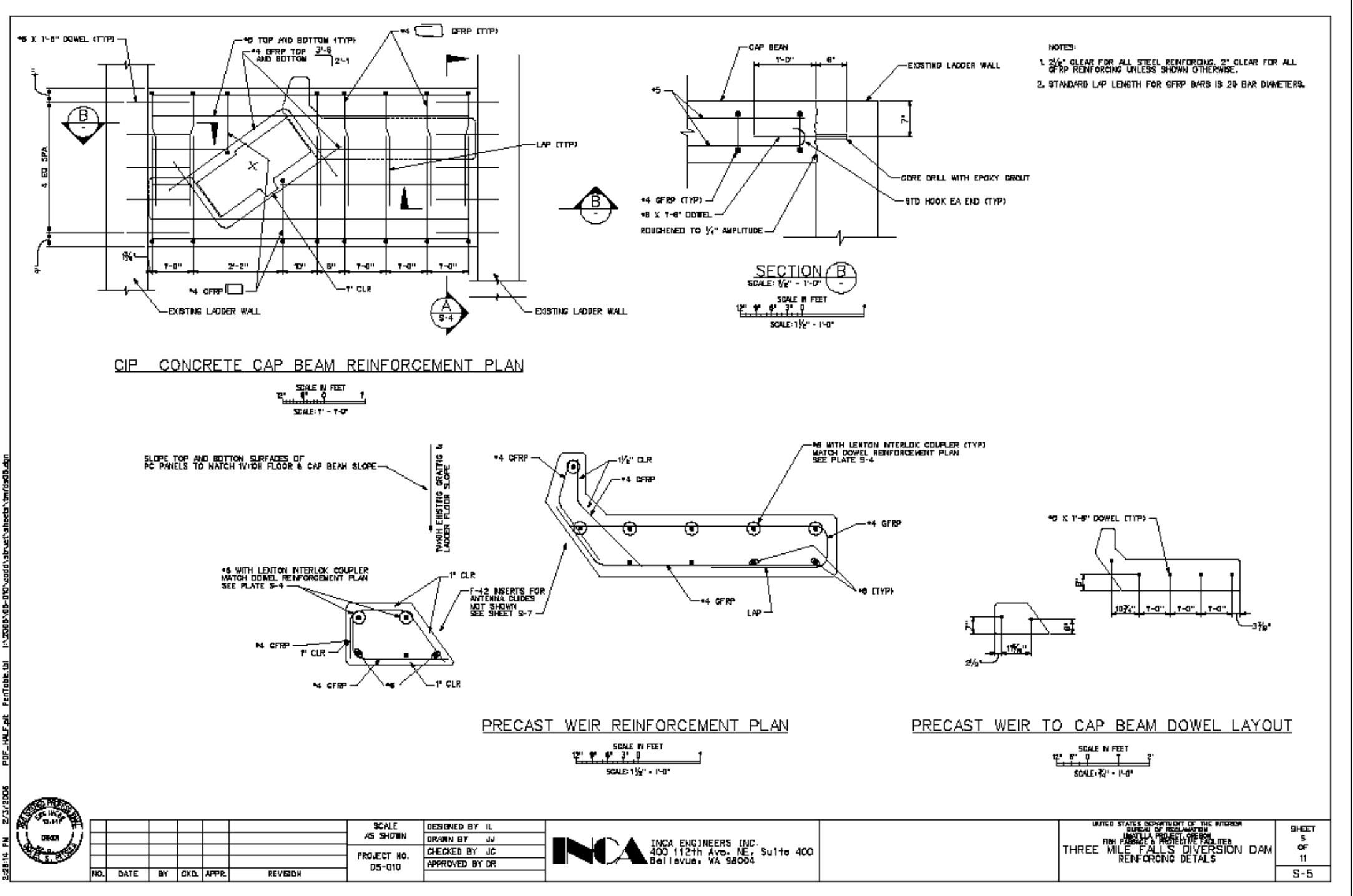


Appendix B-2

Construction Drawings

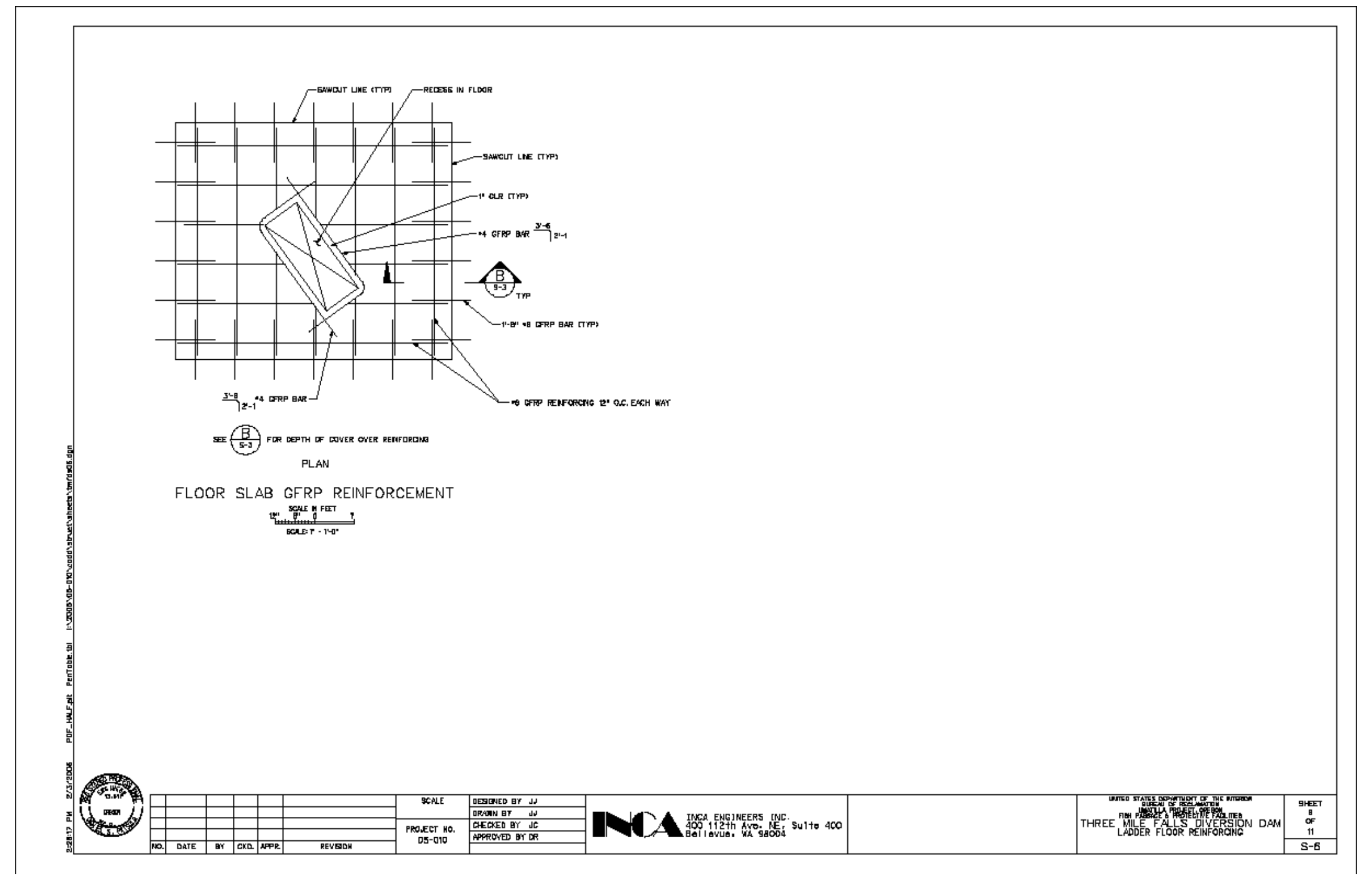


Appendix B-2

Construction Drawings

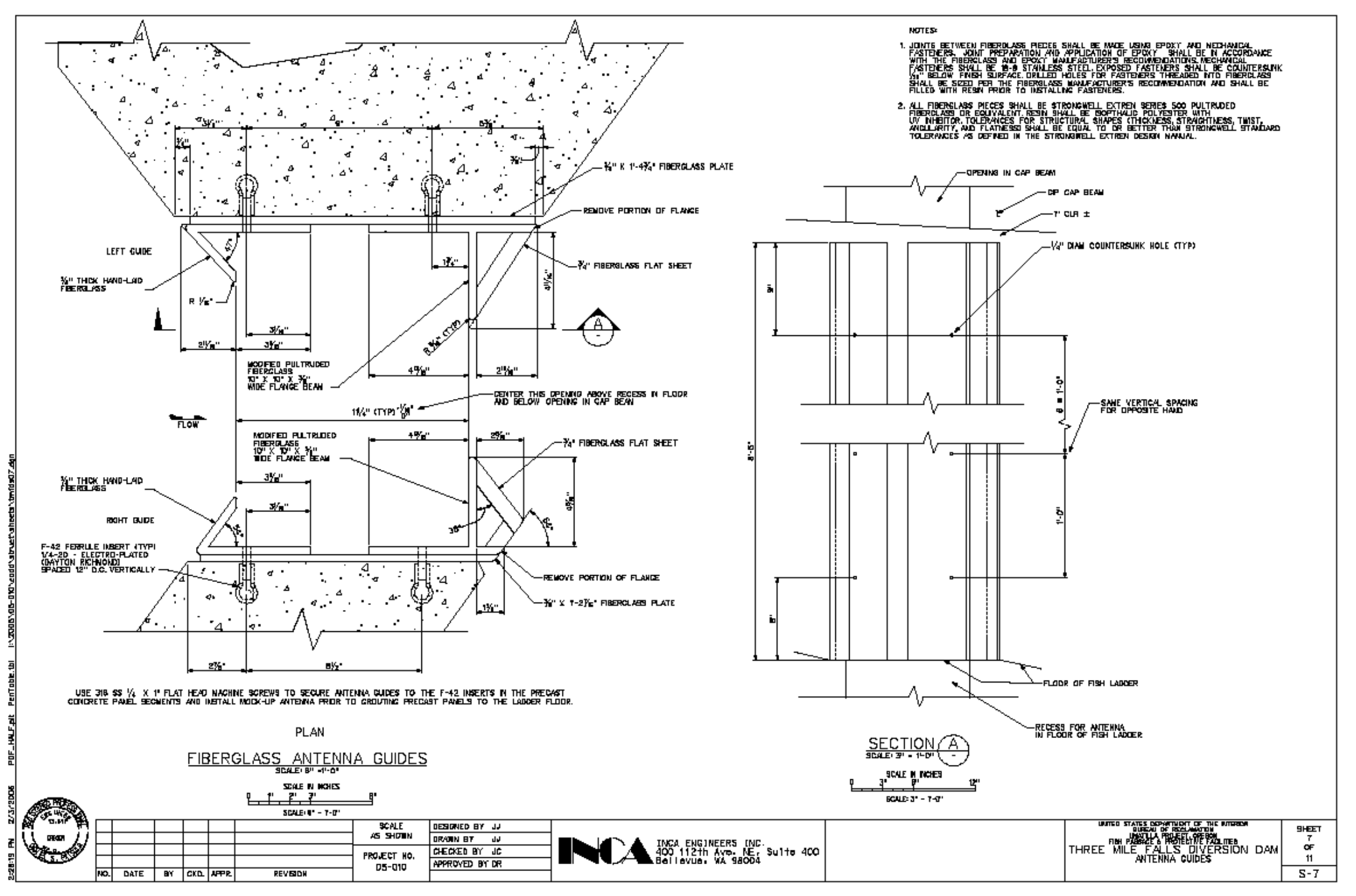


Appendix B-2

Construction Drawings

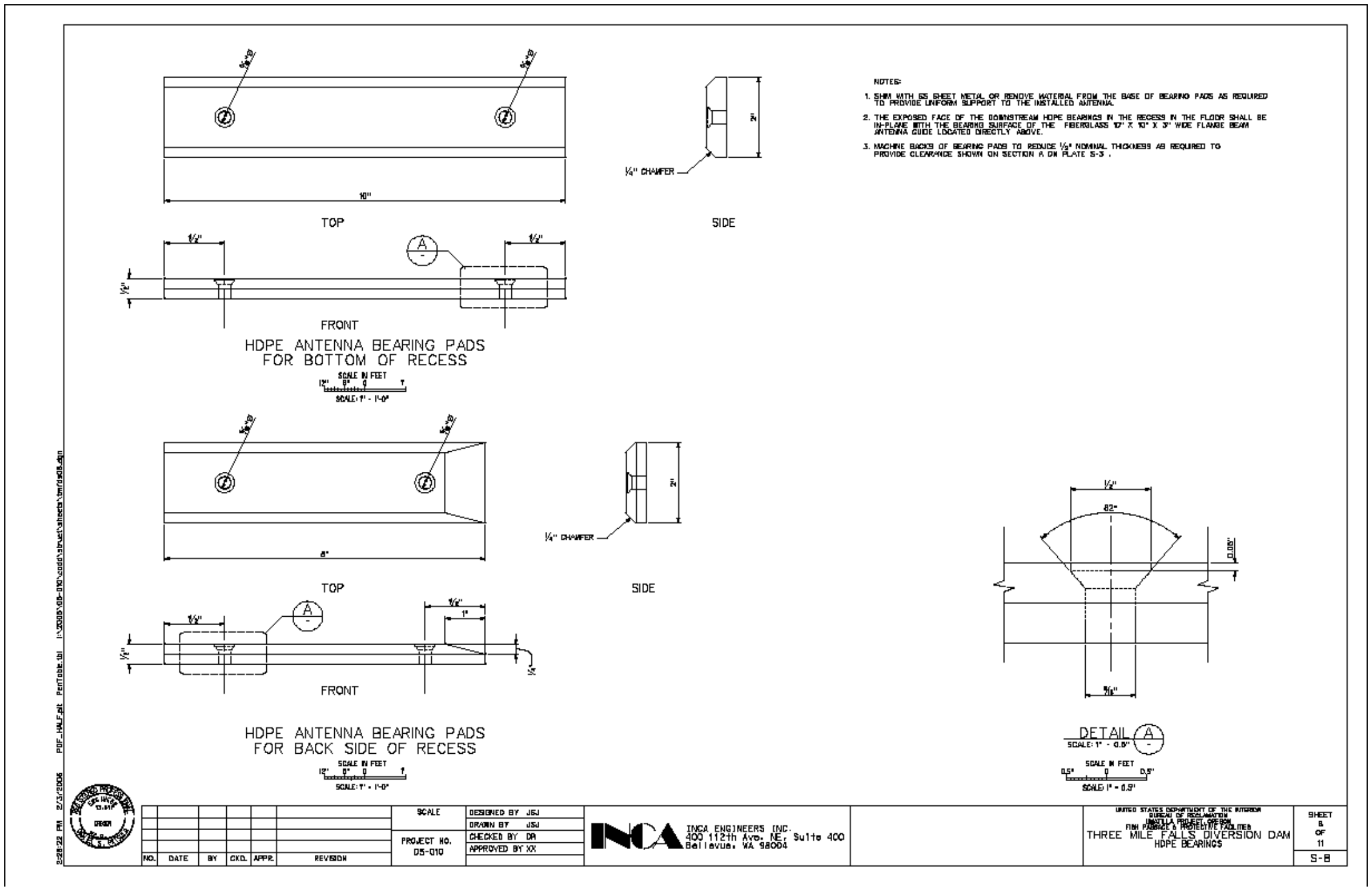


Appendix B-2

Construction Drawings

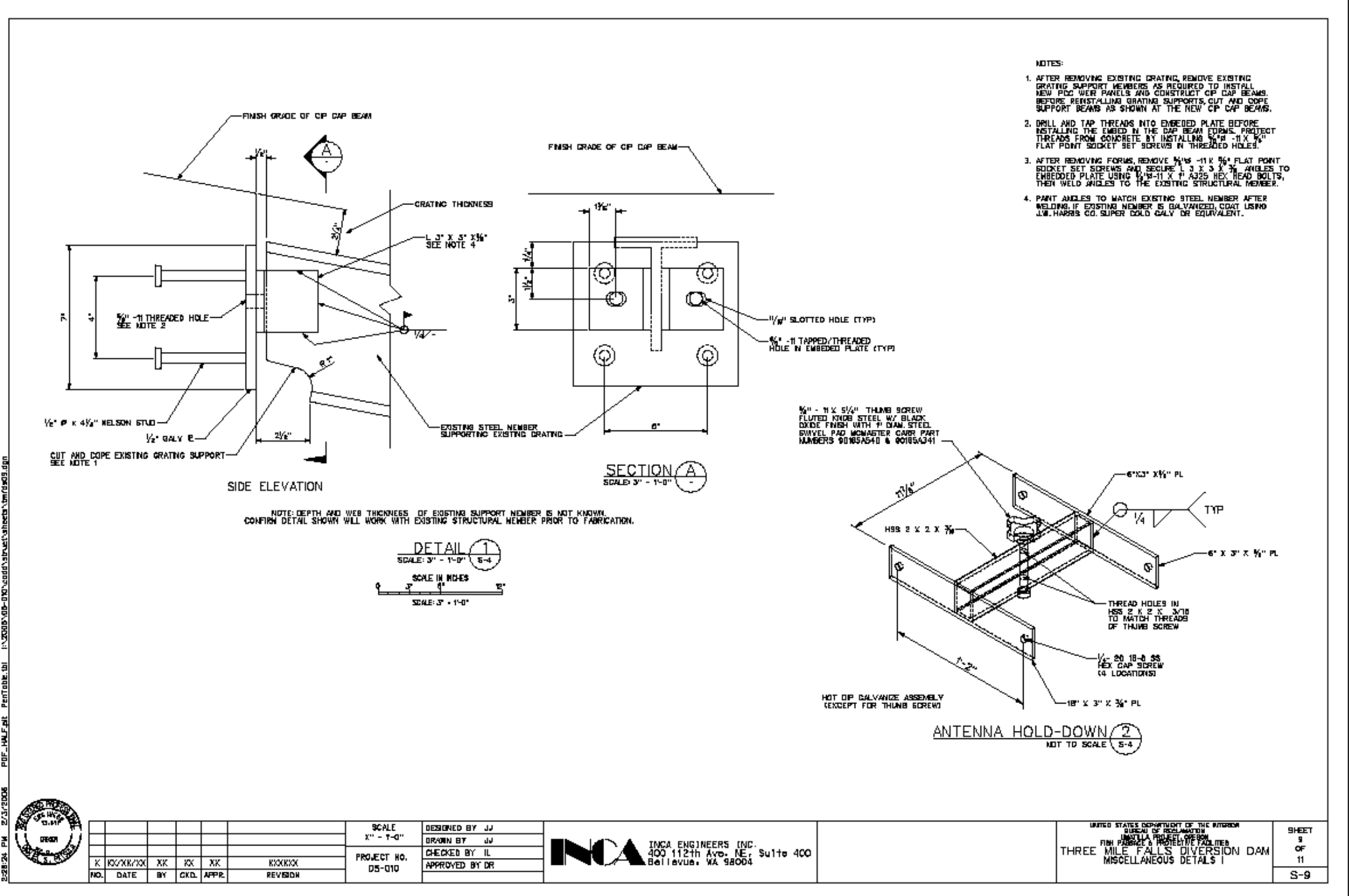


Appendix B-2

Construction Drawings

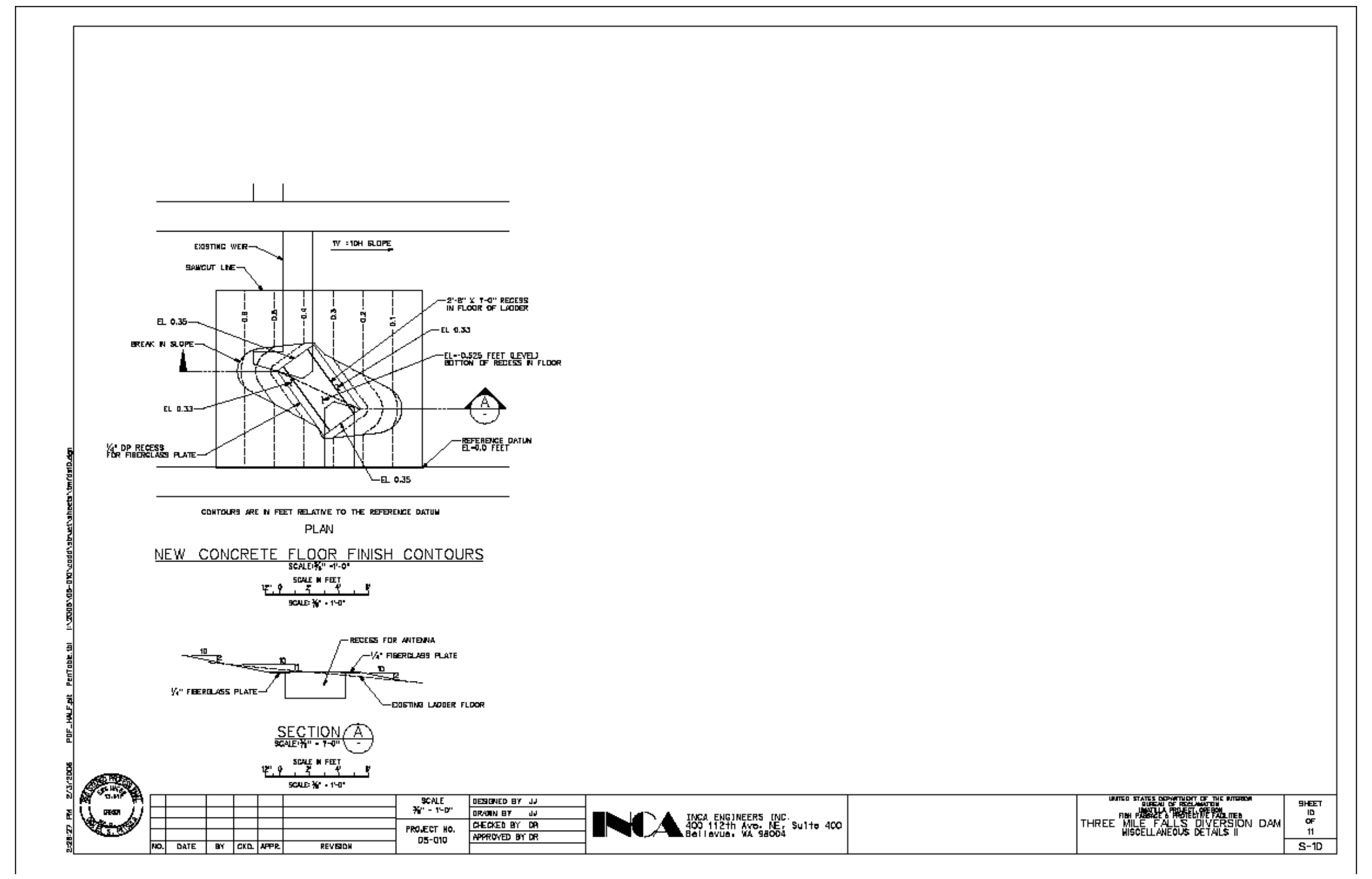


Appendix B-2

Construction Drawings

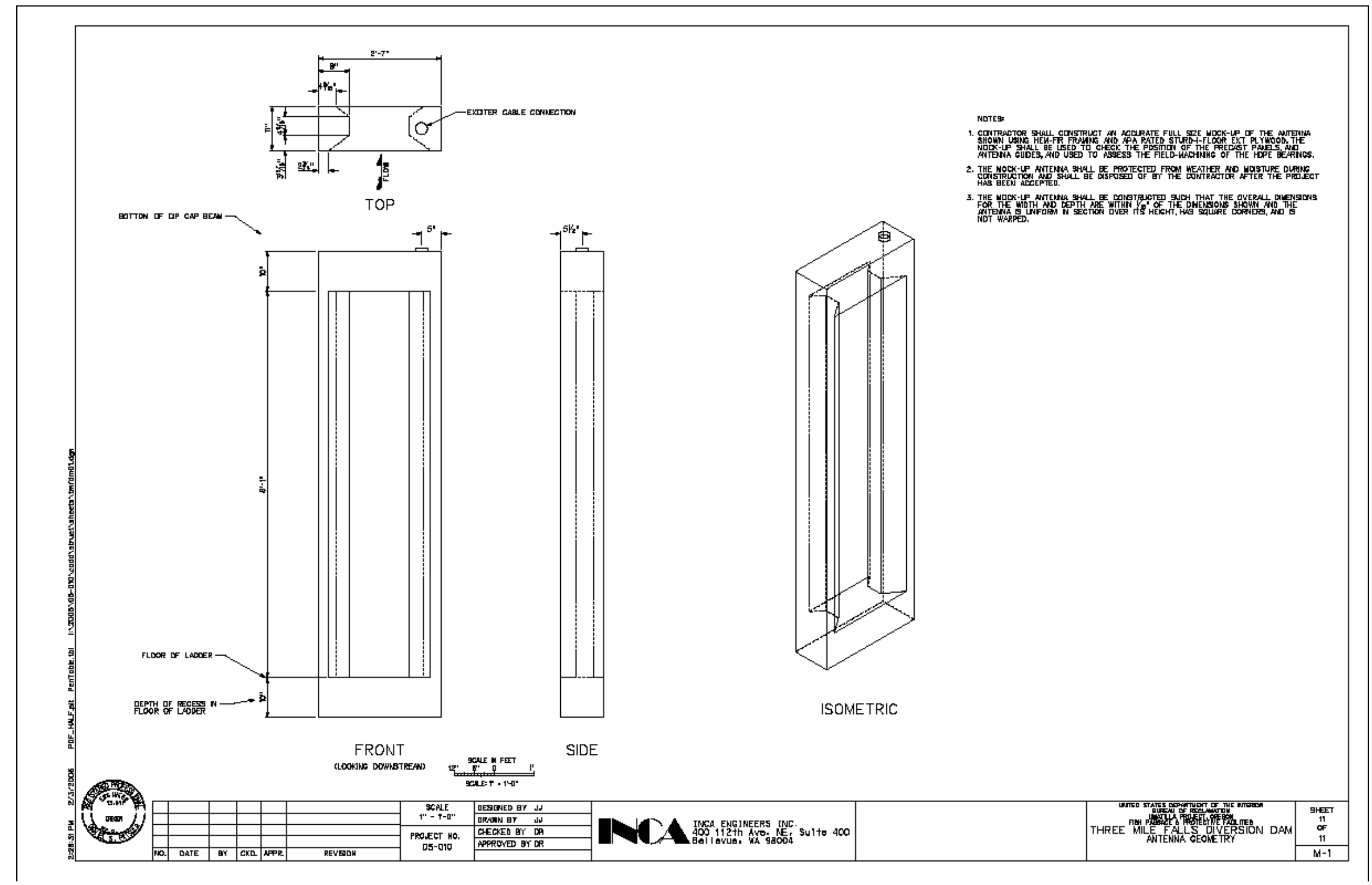


Appendix B-3

Three Mile Falls Diversion Dam Ladder Modifications for PIT Tag Detection

Calculations

prepared for:

Oregon Department of Fish \& Wildlife

Fisheries Research

$80866 \mathrm{Hwy} 395 \mathrm{~N}$

Hermiston, OR 96838

prepared by:

INCA Engineers, Inc.

400 - 112th Ave. SE, Suite 400

Bellevue, WA 98004

(Inca Job No.: 05-010)

February 206 


\section{CERTIFICATE OF ENGINEER}

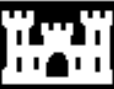

The work contained herein was prepared under the supervision and direction of the undersigned.

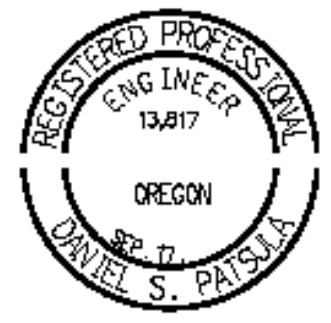

Daniel S. Patsula, P.E.

Vice President 


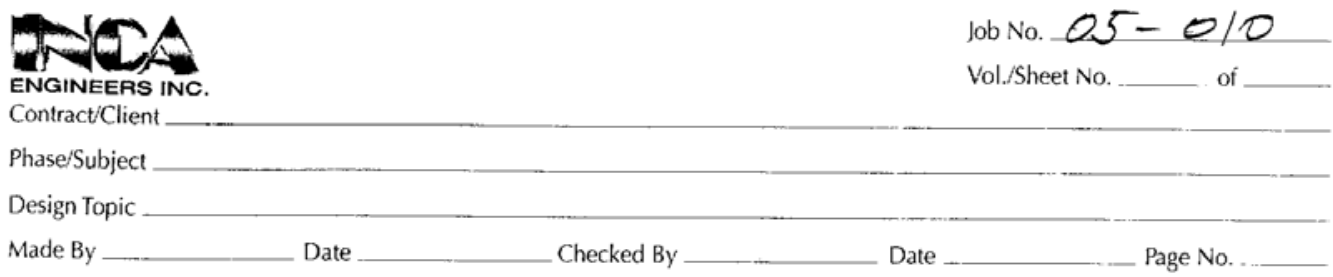

\section{THREE MILE FALLS DAM. PIT TAG}
1. DESIGN DATA
$D 1-D 2$
2. CIP CAP BEAM
$1-8$
3. WETR
$9-17$
4. REFERENCES
$R /-R 10$ 


$\begin{array}{ll}\text { crom: } & \text { Jeff Juel [j.juel@incainc.com] } \\ \text { ent: } & \text { Wednesday, September 21, 2005 8:42 AM } \\ \text { To: } & \text { Brian Twitchell } \\ \text { Cc: } & \text { Dan Russell (E-mail) } \\ \text { Subject: } & \text { 05-010 - Three mile falls dam fish ladder grating loading criteria }\end{array}$

Brian,

The cap beam on the new weirs may/will need to support the end of a steel

beam at mid-span. The existing steel beam supports the adjacent grating. I

found a reference to the walkway grating in a document this morning. The

design load for the grating is $150 \mathrm{psf}$ uniform live load or $1000 \mathrm{lb}$ point

load.

We need to consider this loading when designing the cap beam. See me if you

have questions.

Jeff 


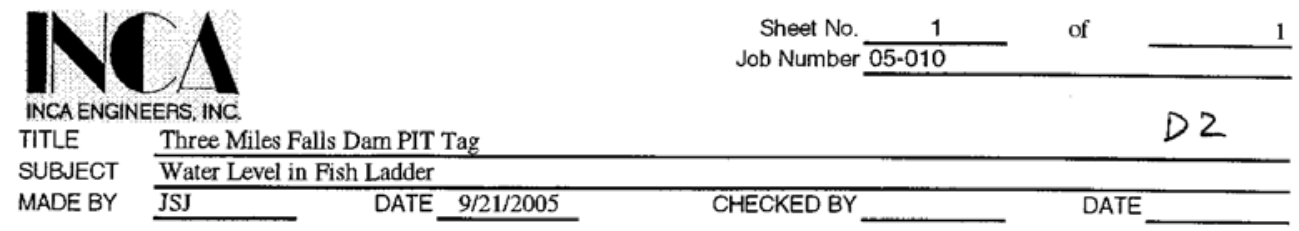

From Designer's Operating Criteria dated 06-17-94

\begin{tabular}{ccc} 
Flow Condition & $\begin{array}{c}\text { Headwater } \\
\text { Elevation }\end{array}$ & $\begin{array}{c}\text { Tailwater } \\
\text { Elevation }\end{array}$ \\
\hline High Flow & 405.47 & 395.23 \\
Winter High Flow & 405.12 & 395.06 \\
Low Flow & 404.78 & 394.79 \\
No Flow & 404.30 & 394.67
\end{tabular}

Assume that the water level in the fish ladder is defined by an equal head drop at each of the project fish ladder's ten pools and that the water levels at the entrance pool and exit pool match the tailwater and headwater elevations respectively.

\begin{tabular}{ccccc} 
Flow Condition & $\begin{array}{c}\text { Headwater } \\
\text { Elevation }\end{array}$ & $\begin{array}{c}\text { Tailwater } \\
\text { Elevation }\end{array}$ & $\begin{array}{c}\text { Total Head } \\
\text { Drop }\end{array}$ & $\begin{array}{c}\text { Drop per } \\
\text { Pool }\end{array}$ \\
\hline High Flow & 405.47 & 395.23 & 10.24 & 1.024 \\
Winter High Flow & 405.12 & 395.06 & 10.06 & 1.006 \\
Low Flow & 404.78 & 394.79 & 9.99 & 0.999 \\
No Flow & 404.30 & 394.67 & 9.63 & 0.963
\end{tabular}

Pools \#8 and \#10 are immediately upstream from the two proposed new weirs.

\begin{tabular}{ccc} 
& \multicolumn{2}{c}{ Water Level } \\
Flow Condition & Pool \#8 & Pool \#10 \\
\hline High Flow & 402.398 & 405.47 \\
Winter High Flow & 402.102 & 405.12 \\
Low Flow & 401.783 & 404.78 \\
No Flow & 401.411 & 404.30
\end{tabular}

Also of use is the floor elevation in the fish ladder at the proposed new wiers.

The floor slopes at $1 \mathrm{~V}: 10 \mathrm{H}$, and the floor elevation at the 180 degree turn in the ladder is 394.25 .

The ladder pools are 10 feet long and the weirs to be replaced are 10 feet and 30 feet from the toe of the floor slope.

Floor elevations at new weirs ---> $\quad 395.25 \quad$ and $\quad 397.25$

\begin{tabular}{ccc} 
& \multicolumn{2}{c}{ Water Depth } \\
Flow Condition & Pool \#8 & Pool \#10 \\
\hline High Flow & 7.15 & 8.22 \\
Winter High Flow & 6.85 & 7.87 \\
Low Flow & 6.53 & 7.53 \\
No Flow & 6.16 & 7.05
\end{tabular}




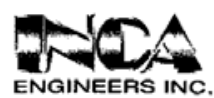

ENGINEERS INC. THREE MILE: FALLS DAM PIT TAG

Job No. $05-010$

Vol./Sheet No. of

Phase/Subject

Design Topic EIP CAP BEAM

Made By IL Date $9-29-05$ Checked By

Je

Date

$10 / 6 / 05$ Page No. $/$

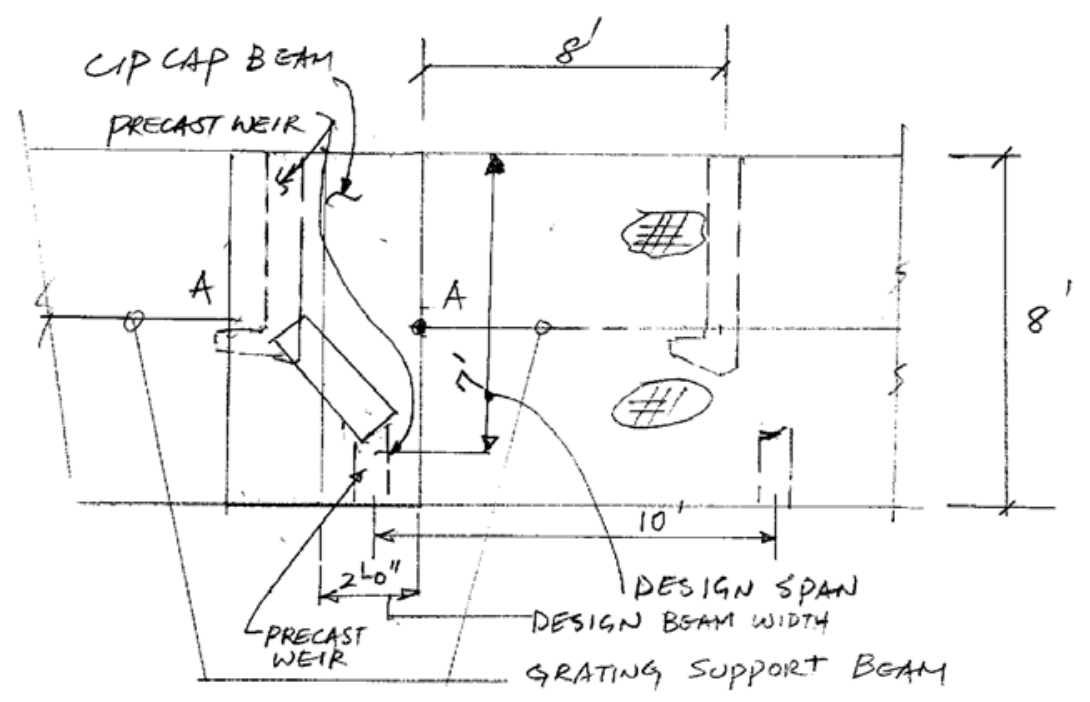

GRATING DESIGN LOAP, 150 PSE OR $1000 \mathrm{~K}$

ASSUME CAP BEAM THCKNESS $=1.5^{\prime}$

BASICALLY, CAP BEAM IS SUPPORED BY PRECAST

WEIRS VERTICALLY. IT IS DOWELLED INTO WALLS

TO SUPPORT UNBALANCED LOADS.

AsSUME

- DESIGN SPAN LENGTH = $7^{\prime}$

DESIKN WIDTH $=(3.833) / 2=1.92^{\prime} \times 2^{\prime}$

DESIGN MODEL :

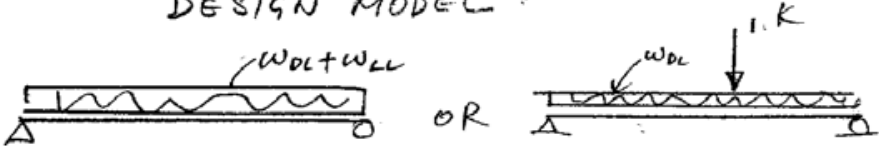




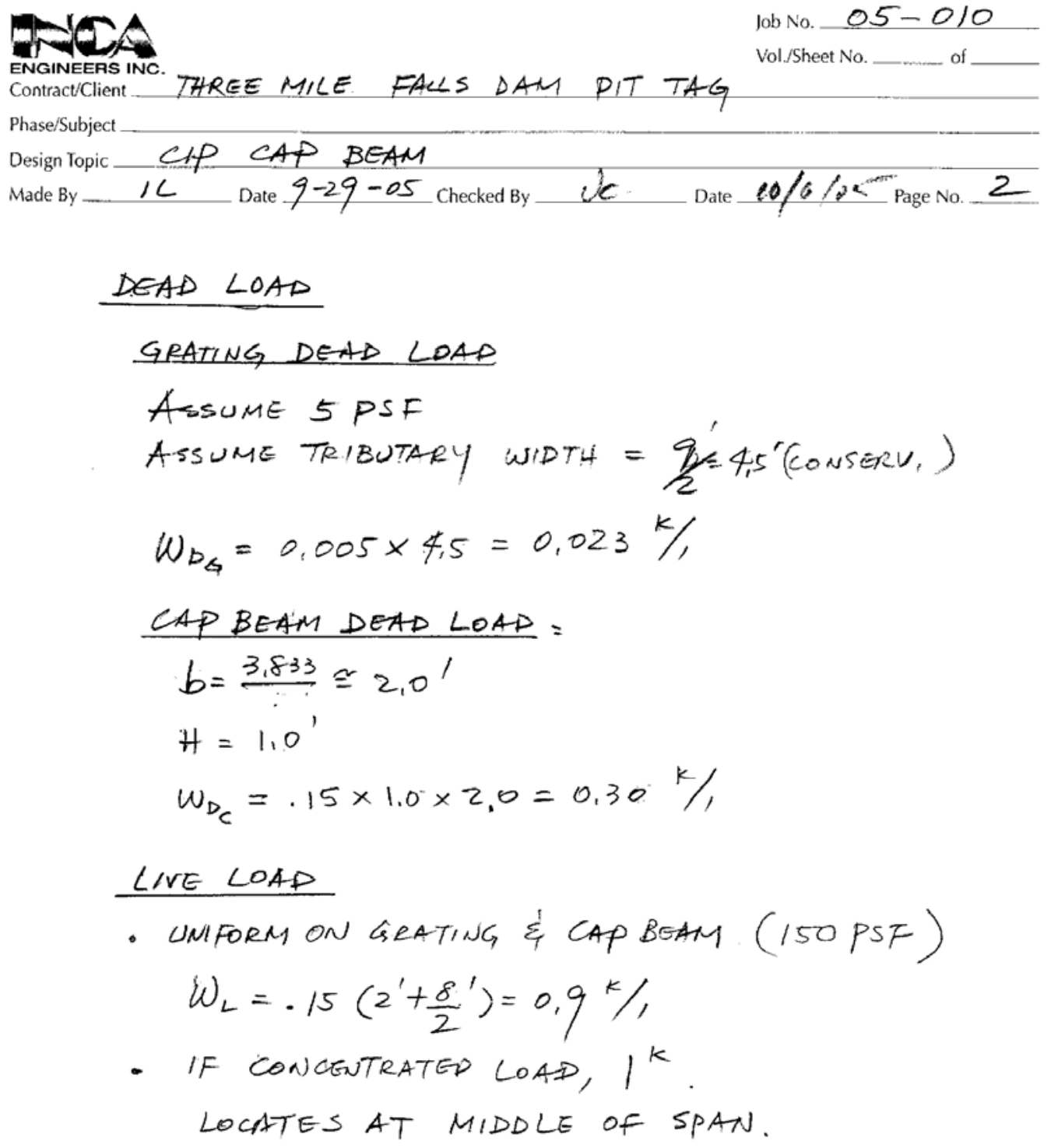


Sos

lob No. $05-0 / 0$ ContractClient THREE MILE FALLS DAM PIT TAG Vol_/Sheet No. of Phase/Subject

Design Topic CAP CAP BEAT I

Made By

K

Date $9-29-05$ Checked By JC

Date $10 / 6 / 0{ }_{\text {Page No. }} 3$

CASE 1.

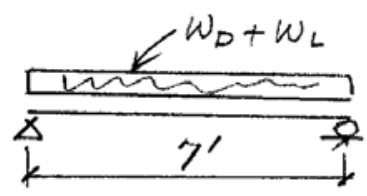

$$
\begin{aligned}
& \begin{aligned}
W & =\omega_{0}+\omega_{L} \\
W_{u} & =1.4(0.023+0.30)+1.7(0.9) \\
& =0.45+1.53 \\
& =1.98 \mathrm{k} / 1
\end{aligned} \\
& \left.\begin{array}{rl}
M_{u} & =\frac{\omega_{u} l^{2}}{8}=\frac{1.98 \times 7^{2}}{8}=12.13 \quad \mathrm{k} \\
\nabla_{u} & =\frac{1.98 \times 7}{2}=6.93 \mathrm{k}
\end{array}\right\} \text { GOVERNS }
\end{aligned}
$$

CASE 2

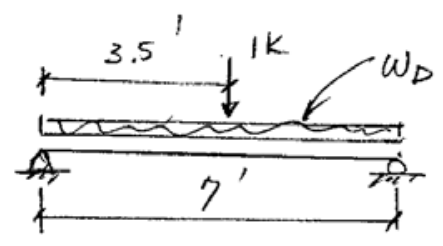

$$
\begin{aligned}
& \omega_{u}=1.4(0.023+0.30)=0.45 \mathrm{k} /, \\
& P_{u}=1.0 \times 1.7=1.7^{\mathrm{k}} \\
& M_{u}=\frac{0.45 \times 7^{2}}{8}+\frac{1.7 \times 7}{4}=2.76+2.98=5.74^{1 \mathrm{k}} \\
& V_{u}=\frac{0.45 \times 7}{2}+1.7=3.28^{\mathrm{k}}
\end{aligned}
$$

81 


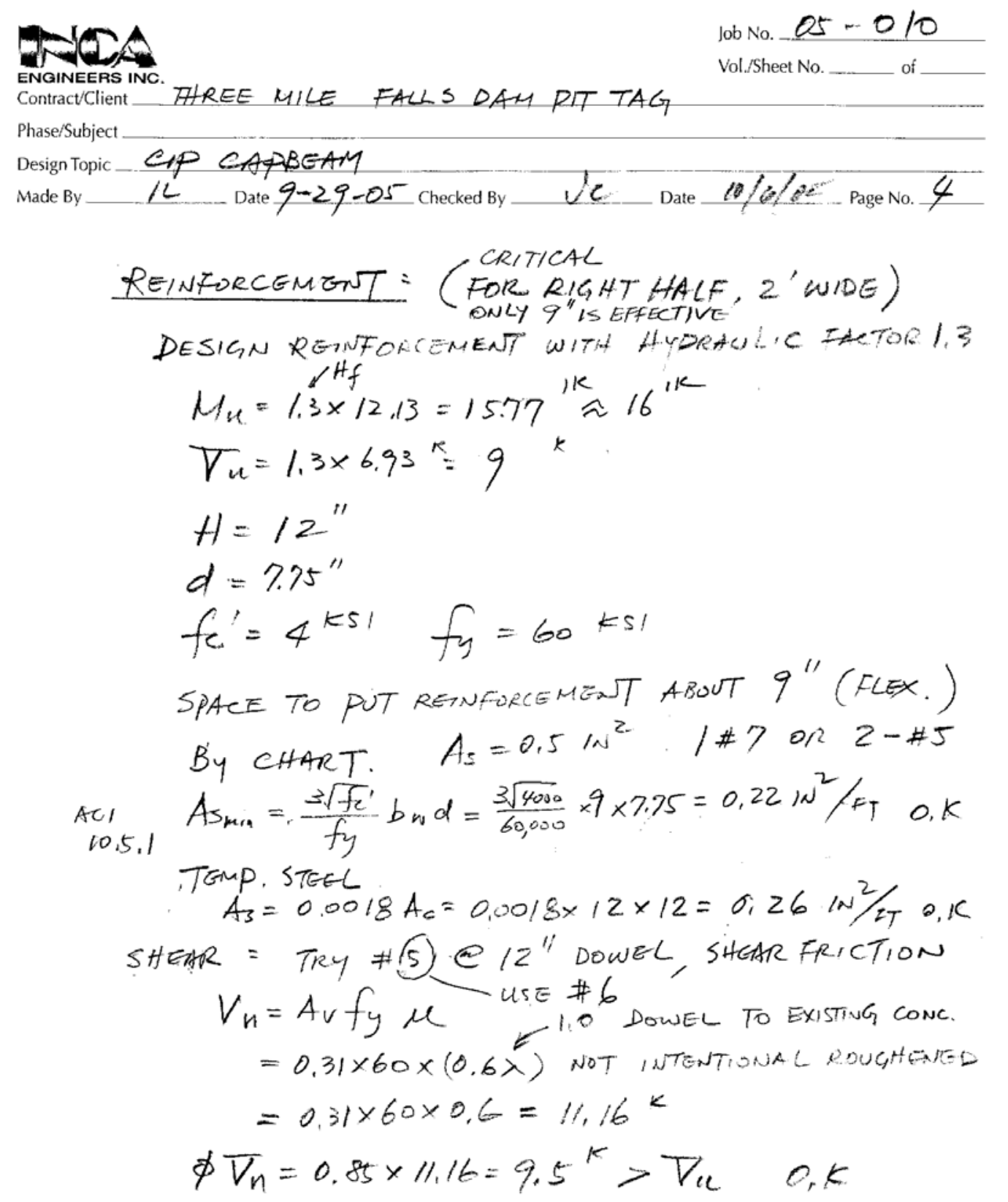




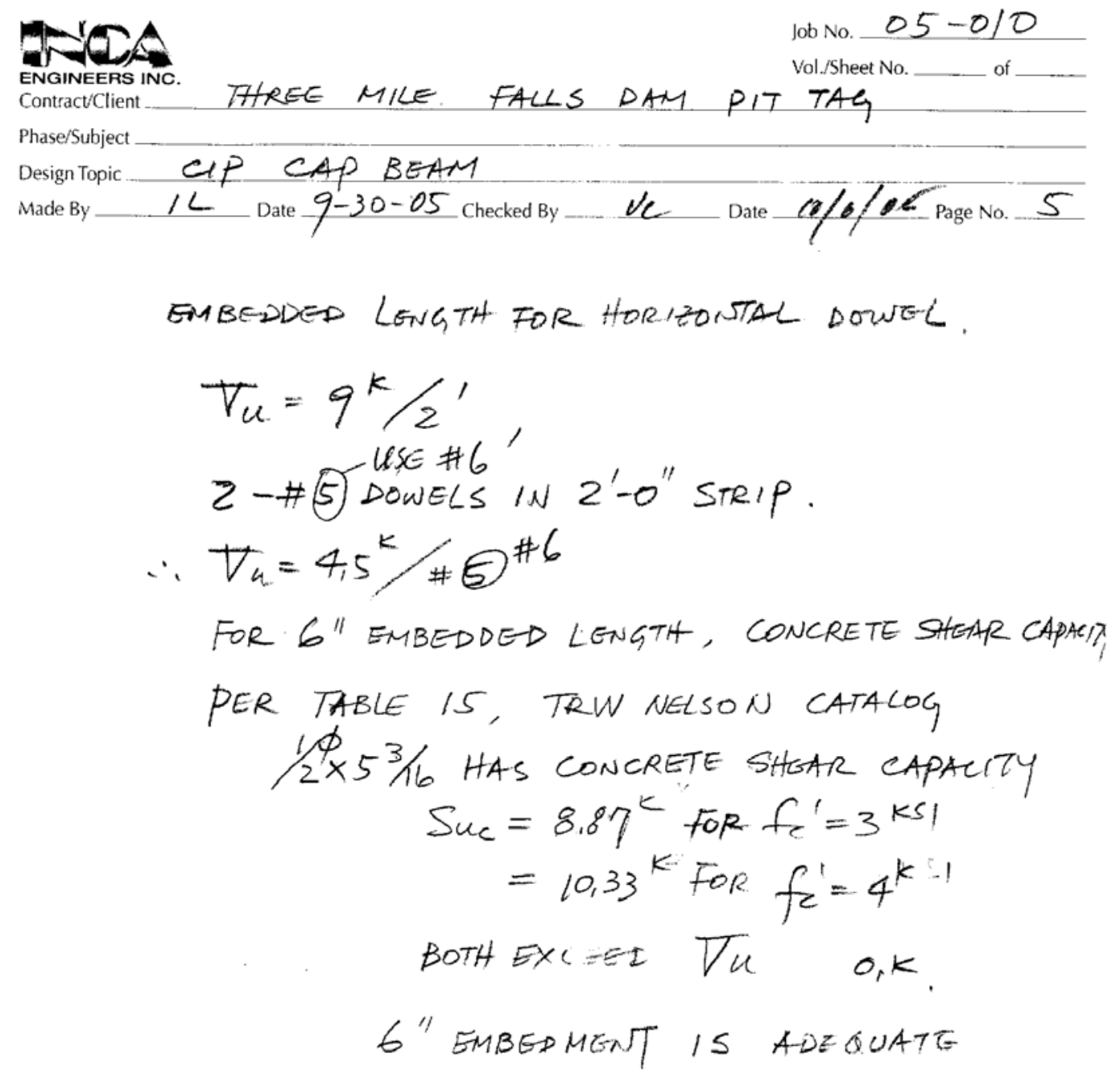


Job No. $05-0 / 0$

Vol./Sheet No. of

Contract/Client

THREE MILE FALLS DAM

PT TAG

Phase/Subject

Design Topic CAP CAP BEAM

Made By $1 \mathrm{~L}$

Date $10-3-05$ Checked By de Date 10

$10 / 6 / 05$

Page No. 6

CHECK VERTICAL SHEAR:

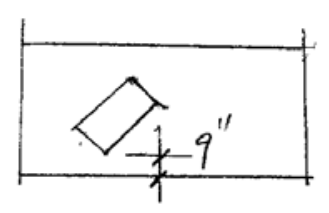

$V_{u_{\text {max }}}=6.93^{\mathrm{K}}$

$\phi v_{c}=2 \phi, F_{f_{c}}=2 \times 0,85 \sqrt{4000}=108 \mathrm{ps} 1$

$b=$ MIN WIDTH AT OPENING FOR INSTRUMENT $=9^{\prime \prime}$

$A_{c}=b \cdot d=q^{\prime \prime} \times 9,5^{\prime \prime}=85,5 \mathrm{in}^{2}$

$\underbrace{\phi \nabla_{n}=\frac{108 \times 85.5}{1000}=9.23^{k}}_{\text {ADD ONE \#5 EACH SIDE AS SHEAR FRICTION }}>\nabla_{\text {max }} 0 . k$
$<2 \nabla_{u}$ Shear Steal

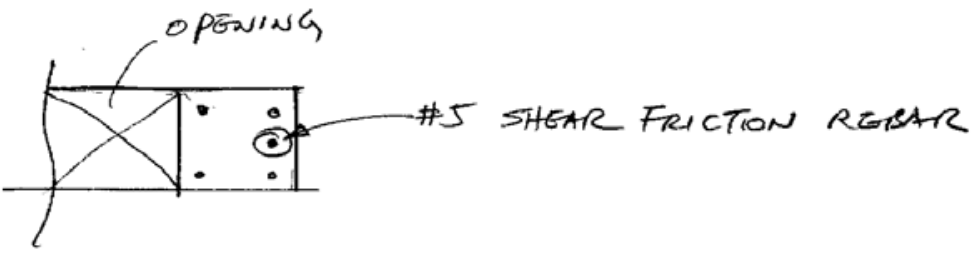

84 

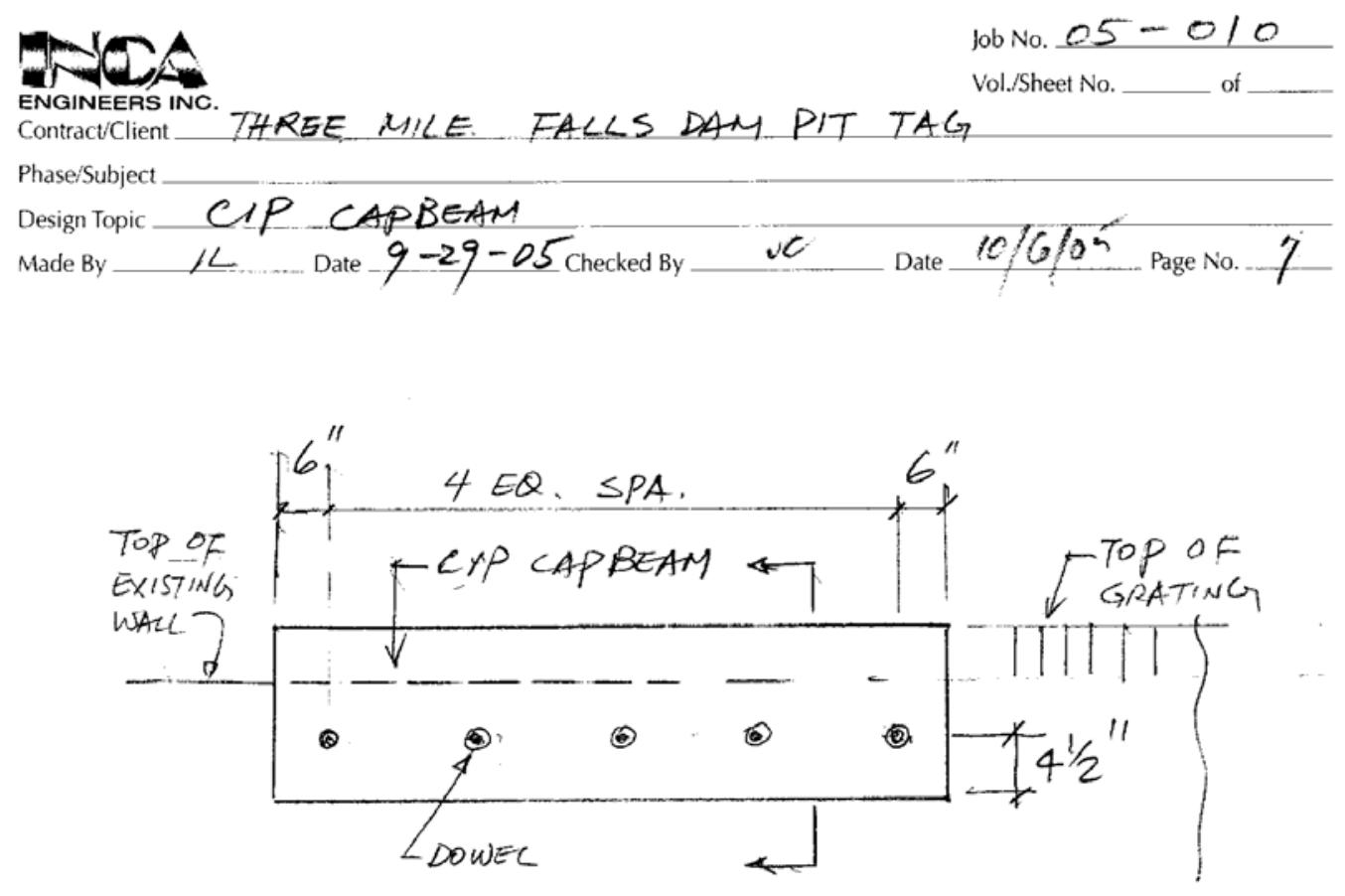

DOWELLING ON WALL

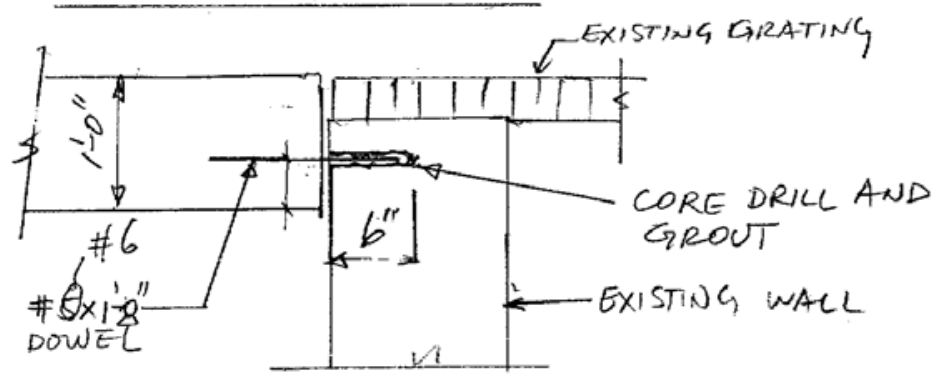

SECTION A-A 
Contracticlient THREE MILE FALLS DAM PIT TAG

Phase/Subject

Design Topic CIP CAP BEAX

Made By $1 \mathrm{C}$ Date $9-29-05$ Checked By $\sqrt{C}$ Date $19 / 6 / 05$ Page No. 8

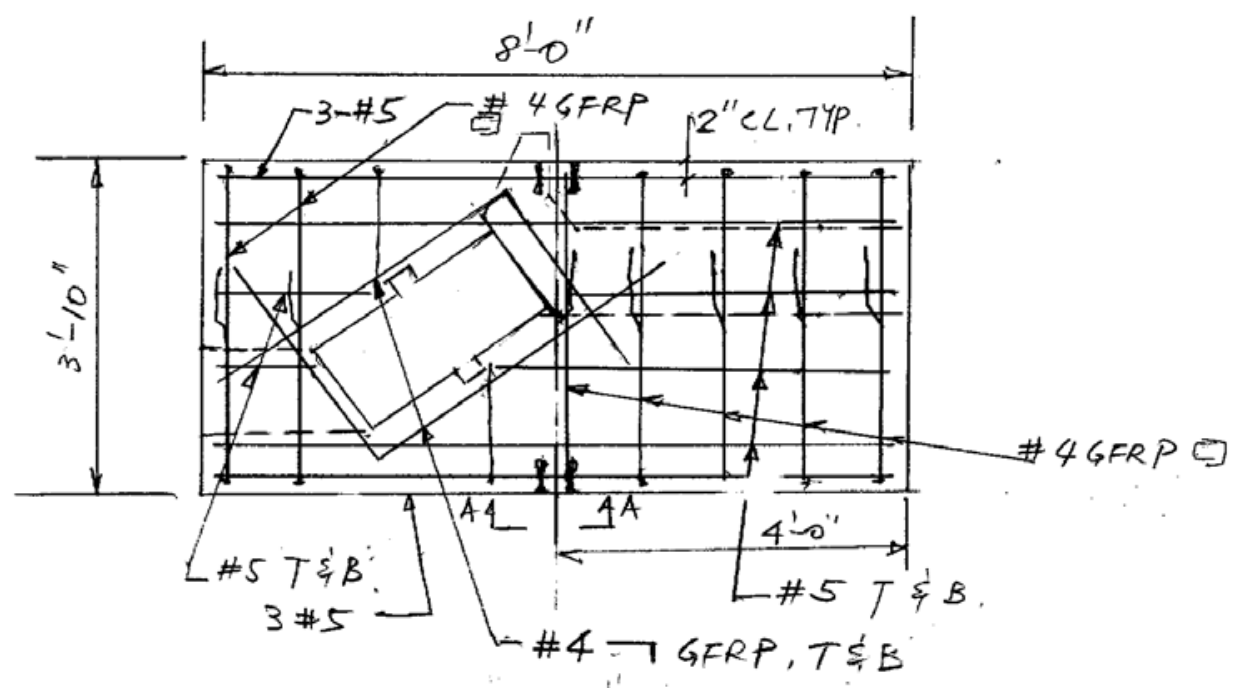

CAPBEAM PLAN

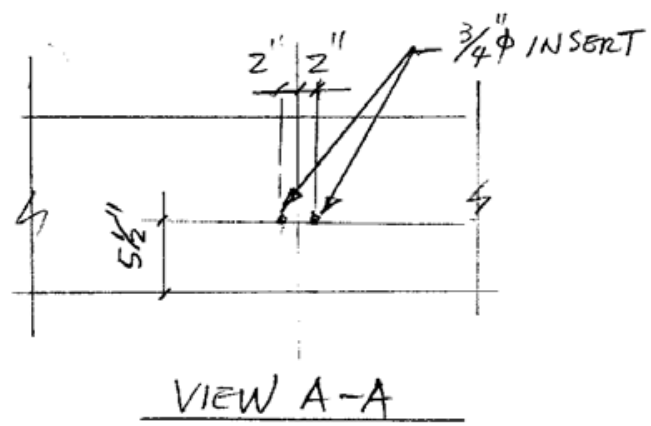




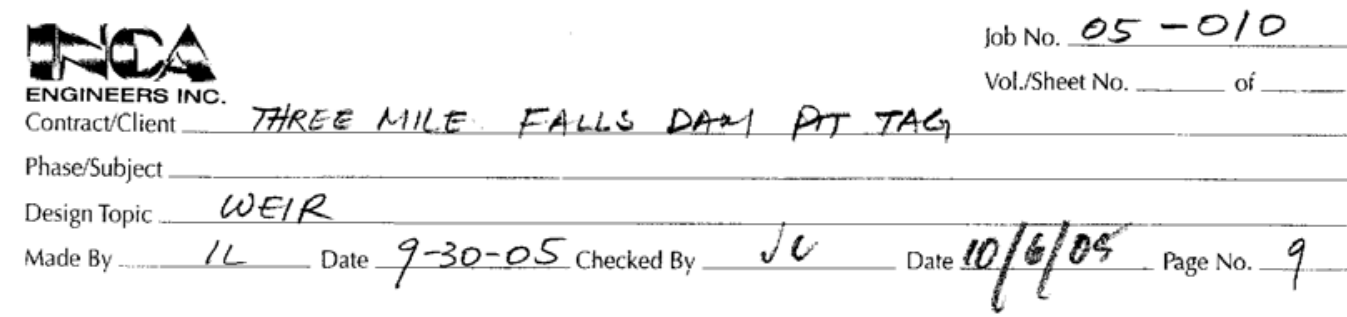

SIZE OF INSERT FOR BEAM ATTACHING

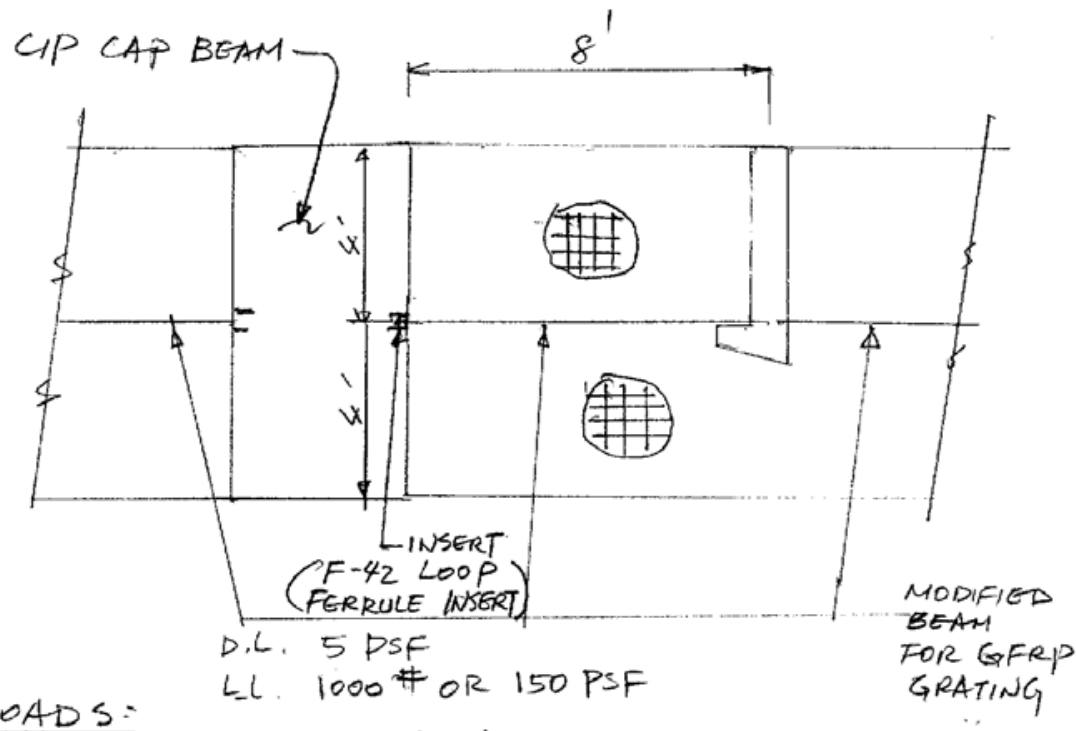

LOADS:

D.L. $\quad R_{D}=0.05 \times \frac{8}{2} \times \frac{8}{2}=0.8 \mathrm{~K}$

L.L $\quad R_{L}=1^{k}$

or L.L. $\quad R_{L}=.15 \times \frac{8}{2} \times \frac{8}{2}=2.4^{\mathrm{K}} \leftarrow$ Goverans

$$
R_{0}=(0.8 \times 1.4+2.4 \times 1.7) \times 1.3=6.76^{\mathrm{K}}
$$

FOR $3 / 4 " \phi$ A 307 PER AISC 3 R.D ED, PAGE 7-33

$$
\phi \bar{V}_{n}=7.95^{\mathrm{k}} / \mathrm{BOLT}
$$

FOR $2-3 / 4 " \phi \quad A 307$,

$\phi \nabla_{n}=2 \times 7.95=15,9^{\mathrm{K}}>R_{4}$ O, K.

CONSERVATIVE, BUT GOOD FOR EQUIPMENT LOAD.

USE $2-3 / 4 " \phi$ INSERT 
Contract/client TitREE MIVE KALS DAM PIT TAG

Phase/Subject DEslunt LoADe / KSSUMPTION

Design Topic

Made By BRutal Date $9 / 05$ Checked By 12 Date

DESIGTA ASEMAPTIONE

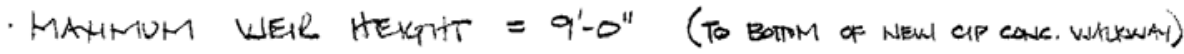

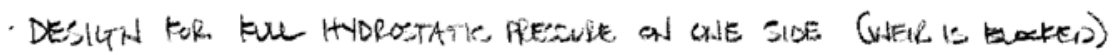

- Weir thekness = $12^{\prime \prime}$

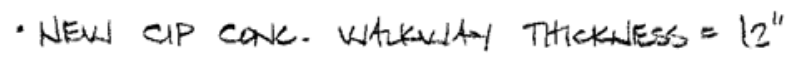

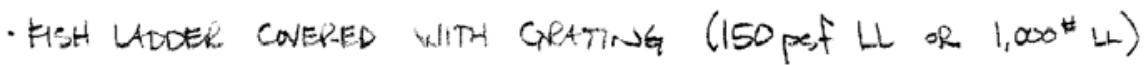

- BEtM kT CENtike of Weik to suppart gPatinta

- ATACH BEAM TO NEN CIP CONK. LALKINAAd

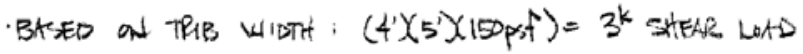

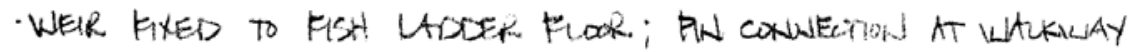

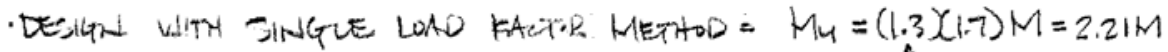

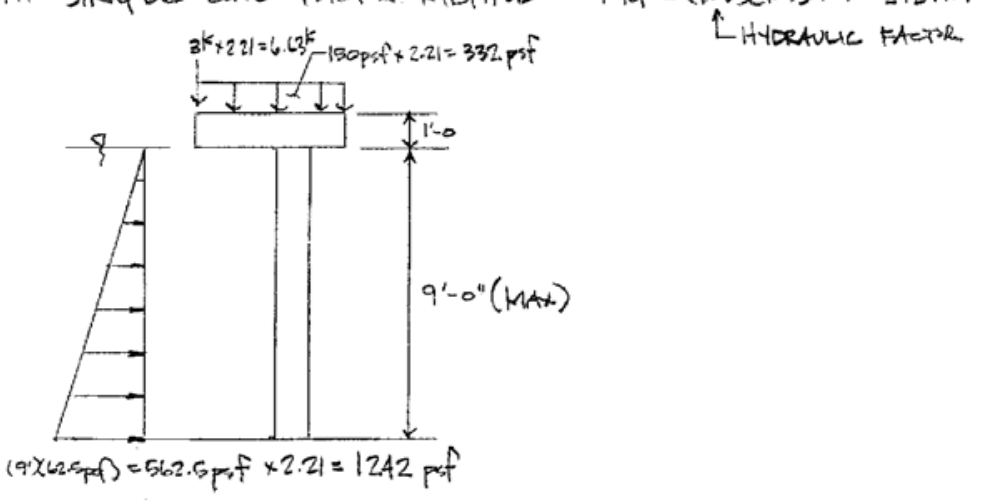



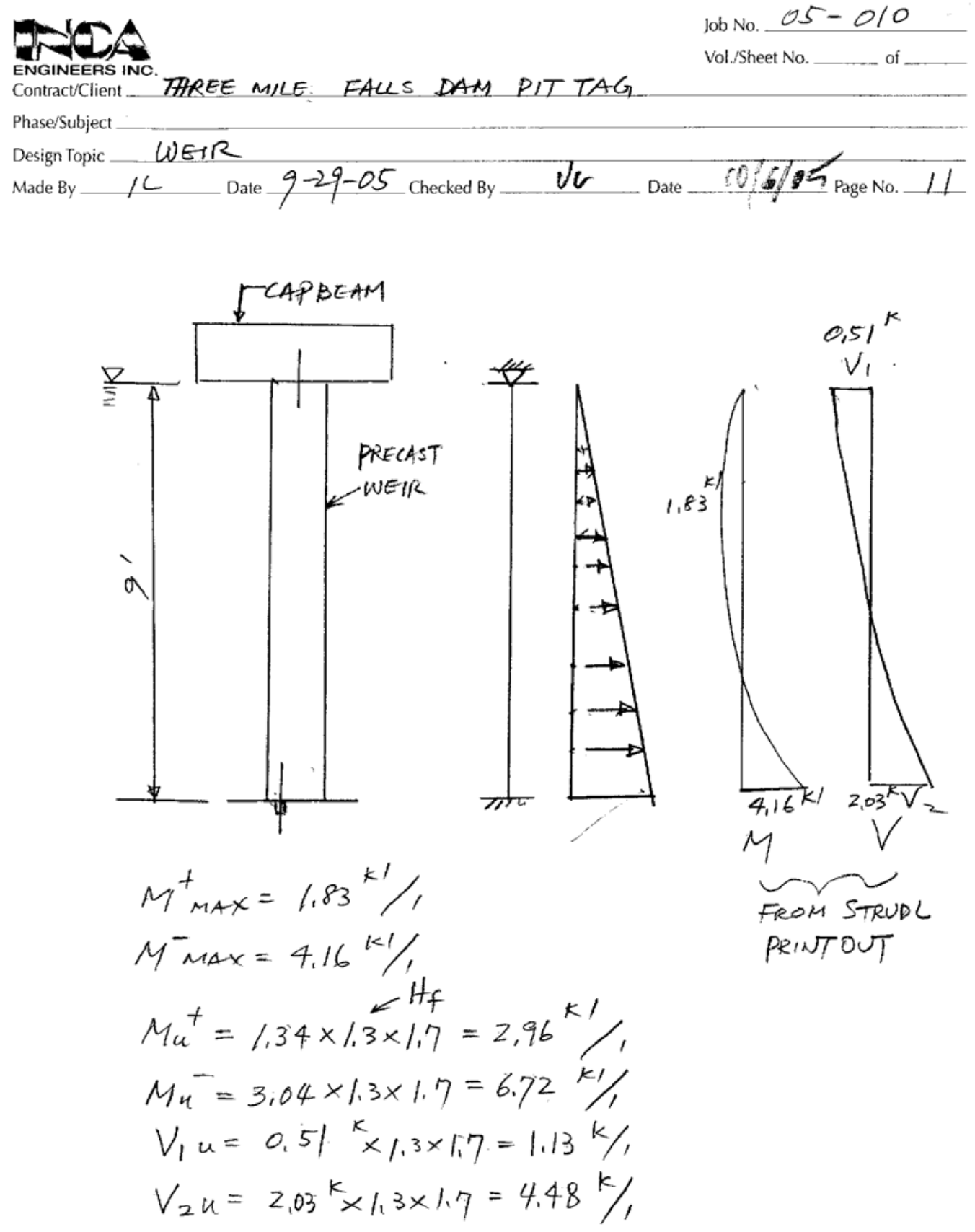
INes

lob No. $05-0 / 0$

Vol./Sheet No.

of

Contract/lient THREE MILE FALLS DAM RIT TAG

Phase/Subject

Design Topic WEIR

Made By

$12 \quad$ Date $9-29-05$ - Checked By

vo

Date $10 / 0105$

Page No. 12

DESIGN FOR $M_{u}^{+}=2,96^{\mathrm{k}} / \mathrm{FT}$

$$
\begin{aligned}
h & =12^{\prime \prime} \\
d & =9,5^{\prime \prime} \\
f_{c}^{\prime} & =4^{\mathrm{ks}} \quad f_{3}=60 \mathrm{ks}, \\
A_{s}=A_{\text {min }}=200 \mathrm{bwd} / f_{y} & =200 \times 12 \times 9,5 / 60,000=0,38^{\prime \prime} \\
& \# 6 @ 12^{\prime \prime}
\end{aligned}
$$

DESIGN FOR $M_{n}^{-}=6.72 \mathrm{k} / 1$

$$
\begin{aligned}
& h=12^{\prime \prime} \\
& d=9.5^{\prime \prime}
\end{aligned}
$$

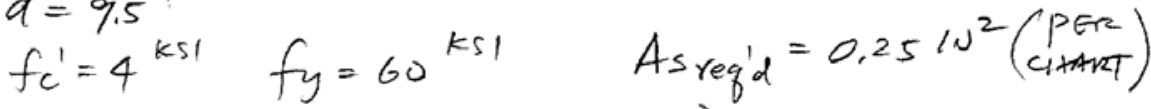

$$
\begin{aligned}
& A_{s}=A_{s \min }=200 \mathrm{bud} / f_{y}=0,38 \mathrm{~m} / \mathrm{s} \\
& \text { \#6@12" }
\end{aligned}
$$

DESIGN FOR VII,

Force sMALl, USE \#5 12 "Dowel.

DESIGN FOR $V_{2 U}=4,48^{\mathrm{K}}$. Assume \#6 $A_{3}=0,44$ $\phi \nabla_{s}=0,85$ Avfy $\mu=0,85 \times(0.44-0.25) \times 60 \times 1.0=9,69 \mathrm{k} /$,

As REQUREO FOR FLEXURAL

90 
Phase/Subject WEIRS

Design Topic $1<\quad$ Date 9-30-05 Checked By Date $10 / 6 / 05$ Page No. 13

DOWELING TO EXISTING CONCRETE

1. TENSION FORCE DUE TO BENDING :

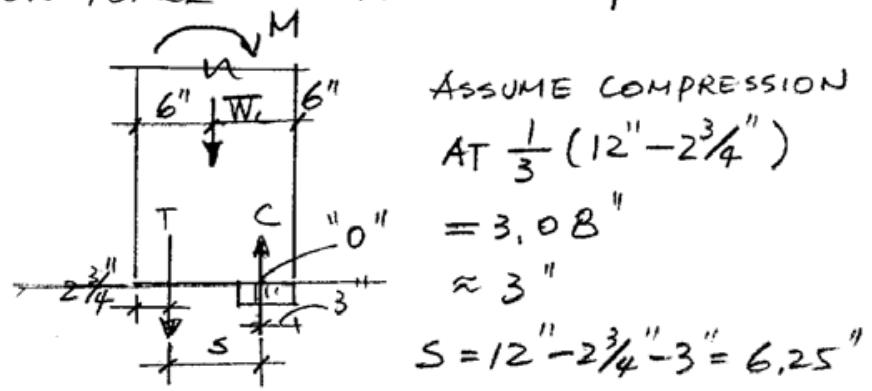

WEIGHT OF WEIR :

$$
W_{C}=.15 \times 1^{\prime} \times 1^{\prime} \times 9^{\prime}=1.35^{\mathrm{k}} / \mathrm{FT}\left(\begin{array}{c}
\text { IGNOR CAP } \\
\text { BEAM WT. }
\end{array}\right)
$$

$M_{u}=6.72^{1 k}$

$$
\begin{aligned}
& d=12^{\prime \prime}-2.75^{\prime \prime}=9.25^{\prime \prime} \\
& a=\frac{.44 \times 60}{0.85 \times 4.0 \times 12}=0.65^{\prime \prime}
\end{aligned}
$$

TENSION REINFORCING, REQUIRED,

$$
A_{S_{\text {reqid }}}=\frac{6.72 \times 12-1.35\left(6^{\prime \prime}-3^{\prime \prime}\right)}{0.9 \times 60 \times\left(9.25-\frac{0.65}{2}\right)}=0.152 \mathrm{wn}^{2}
$$

\#6 IS PROVIDED, $A_{S}=0.44 \mathrm{in}^{2}$

EXCESSIVE REINFORING WILL RESIST SHEAR FORCE.

2. SHEAR FORCE.

$$
\begin{aligned}
& \nabla u=4.48 \mathrm{~K} \\
& A_{\text {sregd }}=\frac{4.48}{0.9 \times 60 \times 1.0}=0,083 \mathrm{~N}^{2}
\end{aligned}
$$

3. TOTAL Asreg'd AVrigd $=0,24 \mathrm{~N}^{2}<A_{\nabla}=.44$

$$
\text { EUBED; LGNGTH, } l=\left(\frac{0,24}{0,44}\right) \times 15^{\prime \prime}=8.18^{\prime \prime}=81 / 4 "
$$


Job No. . OS -010

Vol./Sheet No.

of

ENGINEERS INC.

three mile: falls DAM pIT

TAG

Phase/Subject

Design Topic UUE TR

Made By $1<$ Date $\Rightarrow-30-05$ Checked By $C$

Date $10 / 6 / 05$, Page No. 14

FROM CATALOG TOW NELSON STUD

EMBEDMENT PROPERTIES OF HEADED STUDS

table 15 Full EMBEDMENT SHEAR capaCITY

OF HEADED ANCHORS

$$
\begin{aligned}
& \begin{array}{l}
3 / 4 " \phi \times 63 / 6 \text { STUD } \\
4 \text { EQUIVLENT TO \#6 }
\end{array} \\
& \text { Such } \left.=19.99^{\mathrm{K}} \text { for } f_{c}^{\prime}=3 \mathrm{ks}\right) \Rightarrow V_{u} \\
& =23,3^{k} \text { For } f_{c}^{\prime}=4^{k s} J=4,48^{k}
\end{aligned}
$$

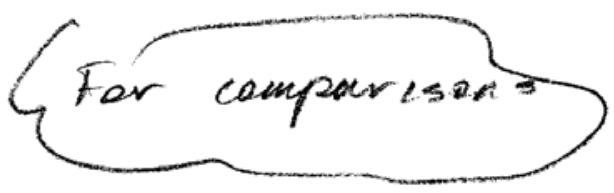

92 


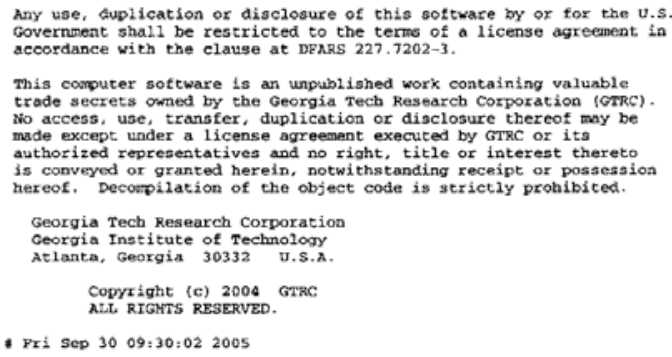

- Fri Sep 30 09:30:02 2005

1GTICES/C-NP 2.5.0 MD-MT 2.0, January 2995.
Proprietary to Ceorgin Tech

D.s.A.

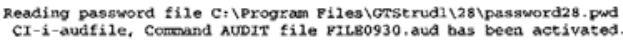

*. G T STRUDL $\cdots$

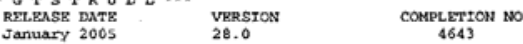

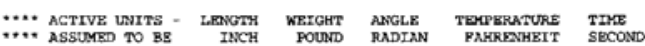

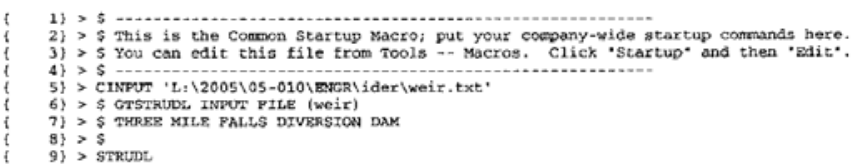

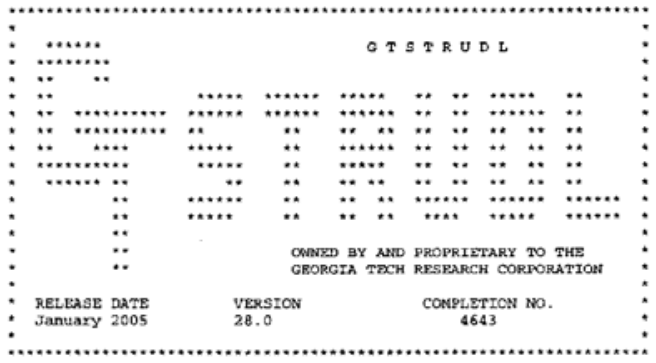

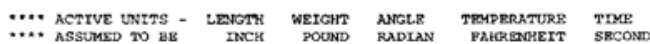

10) > UNIT KIP FT SEC RADINA

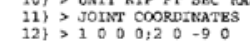

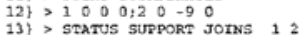

14) > $>\$$

15) > JOINT RRLEASE
$161>2$ WOMLOTI 2

18) $>$ TYPB SPACE PRAME

19) $>$ MEMEER INCIDENCE
$20\}>112$ 


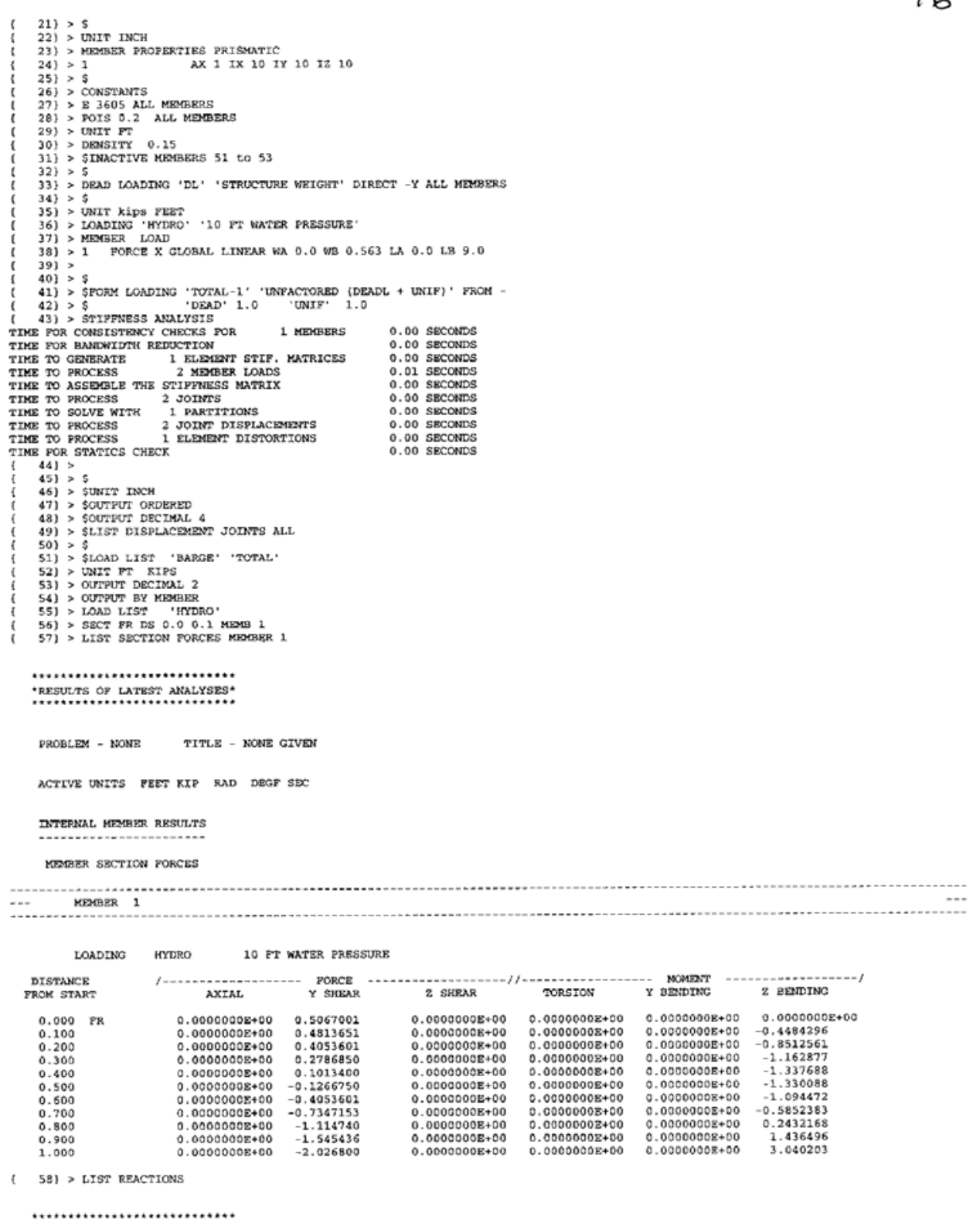


-RESTIAS OP LATEST MANYYSES:

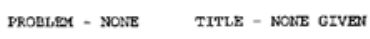

\begin{tabular}{|c|c|c|c|c|c|c|c|}
\hline JOINT & LOADTMG & x PORCB & X FORCE & z PORCE & $x$ монтат & у момант- & z $\mathrm{MOMBN}$ \\
\hline & GLOBAL HYDRO & -0.51 & 0.00 & 0.00 & 0.00 & 0.00 & 0.00 \\
\hline & HYDRO & -2.03 & 0.00 & 0.00 & 0.00 & 0.00 & 3.04 \\
\hline
\end{tabular}

59) > SLOAD LIST ALL.

60) $>$
$611>$
$611>$ 


\section{F-42 Loop Ferrule Insert}

Several features make the F-42 Insert particularly useful to the precaster who must make provision for the anchorage of wall panels, the suspension of ceilings, sprinkler systems, plumbing and heating pipes and ductwork, etc.

The end of the ferrule opposite the tapped end is closed and will not permit entry of fresh concrete. The wire loops provide anchorage suitable for the bolt size required.

For insert capacities under shear loading conditions, please click here.

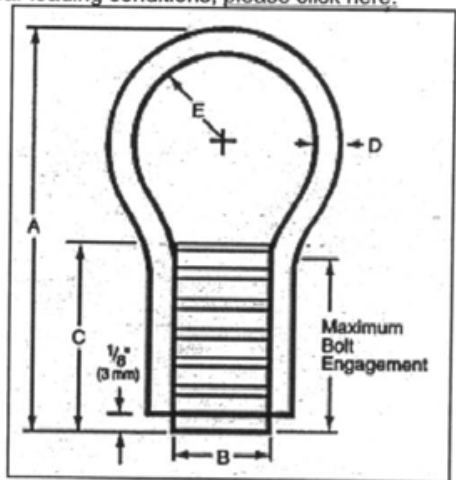

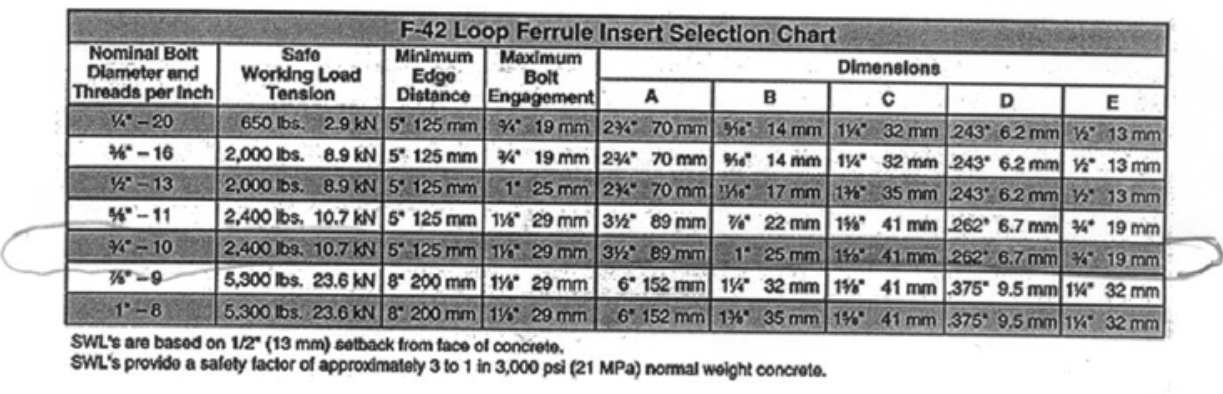

\section{To Order:}

Specify: (1) quantity, (2) type, (3) bolt dia.,(4) finish.

Example:

1,000 pcs., F-42 Loop Ferrule Insert, 1/2" (13 mm)

dia., electro-plated.

DB Grout Sleeve | Formliners | GeneraVT Technical Into | Lifting Systems | Lifting/Handling Inserts

Misc Inserts | Misc Products | NC Threaded Inserts | Product Application Into 
Appendix A

BRIDGE DESIGN MANUAL

Reinforced Concrete Superstructures

Tension Development Length $R 2$ of Straight Uncoated Deformed Bars

Table 5.1-5 - Tension Development Lengths, 4 for Grade 60 Uncoated Bars

Table 5.1-6 - Tension Development Lengths, 4 for Grade 60 Uncoated Bars

\begin{tabular}{|c|c|c|c|c|}
\hline \multirow[b]{2}{*}{$\begin{array}{l}\text { Bar } \\
\text { Size }\end{array}$} & \multicolumn{2}{|c|}{ ld } & \multicolumn{2}{|c|}{$\begin{array}{l}l_{\mathrm{d}} \text { Modified for } \\
\text { Bar Spacing Per } \\
\text { Article 8.25.3.1 } \\
\text { (Spacing } \geq 6^{\circ} \text { ) }\end{array}$} \\
\hline & $\begin{array}{c}\text { Top Bars } \\
\text { FL. - In. }\end{array}$ & $\begin{array}{l}\text { Others } \\
\mathrm{FL} \text { - In. }\end{array}$ & $\begin{array}{l}\text { Top Bars } \\
\text { FL. - In. }\end{array}$ & $\begin{array}{l}\text { Others } \\
\text { Ft. - In. }\end{array}$ \\
\hline 3 & $1^{\prime}-5^{\prime \prime}$ & $1^{\prime}-0^{\prime \prime}$ & $1^{\prime}-2^{\prime \prime}$ & $1^{\prime}-\sigma^{\prime}$ \\
\hline 4 & $1^{\prime}-5^{\prime \prime}$ & $1^{\prime}-0^{\prime \prime}$ & $1^{\prime}-2^{\prime \prime}$ & $1^{\prime}-0^{\prime \prime}$ \\
\hline 5 & 1'-9" & $1^{\prime}-3^{\prime \prime}$ & $-1^{\prime} \cdot 5^{\prime \prime}$ & $1^{\prime}-0^{\circ}$ \\
\hline 6 & $2^{\prime}-3^{\prime \prime}$ & $1^{\prime}-8^{\prime \prime}$ & $1^{\prime}-10^{\prime \prime}$ & $1^{\prime}-4^{\prime \prime}$ \\
\hline 7 & $3^{\prime}-1^{\prime \prime}$ & $2^{\prime}-3^{\prime}$ & $2^{\prime}-6^{\prime \prime}$ & $1^{\prime}-9^{\prime \prime}$ \\
\hline 8 & $4^{\prime}-1^{\prime \prime}$ & $2^{\prime}-11^{\prime \prime}$ & $3^{\prime}-3^{*} 7$ & $2^{\prime}-4^{\prime \prime}$ \\
\hline 9 & $5^{\prime}-2^{\prime \prime}$ & $3^{\prime}-8^{\prime \prime}$ & $4^{\prime}-1^{\prime \prime}$ & $2^{\prime}-11^{\prime \prime}$ \\
\hline 10 & $6^{\prime}-6^{\prime \prime}$ & $4^{\prime}-8^{\prime \prime}$ & $5^{\prime}-3^{\prime \prime}$ & $3^{\prime} \cdot 9^{\prime \prime}$ \\
\hline 11 & $8^{\prime}-0^{\prime \prime}$ & $5^{\prime}-9^{\prime \prime}$ & $6^{\prime}-5^{\prime \prime}$ & $4^{\prime}-7^{\prime \prime}$ \\
\hline 14 & $10^{\prime}-11^{\prime \prime}$ & $7^{\prime} \cdot 10^{\prime \prime}$ & $8^{\prime} \cdot 9^{\prime \prime}$ & $6^{\prime}-3^{\prime \prime}$ \\
\hline 18 & $14^{\prime}-1^{\prime \prime}$ & $10^{\prime}-1^{\prime \prime}$ & $11^{\prime}-3^{\prime \prime}$ & $8^{\prime}-1^{\prime \prime}$ \\
\hline
\end{tabular}
$f_{\mathrm{c}}=4,000$ psi; Normal Weight Concrete

\begin{tabular}{|c|c|c|c|c|}
\hline \multirow[b]{2}{*}{$\begin{array}{l}\text { Bar } \\
\text { Size }\end{array}$} & \multicolumn{2}{|c|}{ ld } & \multicolumn{2}{|c|}{$\begin{array}{l}\text { Ld Modified for } \\
\text { Bar Spacing Per } \\
\text { Article } 8.25 .3 .1 \\
\text { (Spacing } \geq 6 \text { ) }\end{array}$} \\
\hline & $\begin{array}{l}\text { Top Bars } \\
\text { FL. - In. }\end{array}$ & $\begin{array}{l}\text { Others } \\
\mathrm{FL} \text { - In. }\end{array}$ & $\begin{array}{l}\text { Top Bars } \\
\text { Ft. - In. }\end{array}$ & $\begin{array}{l}\text { Others } \\
\mathrm{FL} \text { - In. }\end{array}$ \\
\hline 3 & $1^{\prime}-5$ & $1^{\prime}-0^{\prime}$ & $1^{\prime}-2^{\prime \prime}$ & $1^{\prime}-0^{\prime \prime}$ \\
\hline 4 & $1^{\prime}-5^{\prime \prime}$ & $1^{\prime}-0^{\prime \prime}$ & $1^{\prime}-2^{\prime \prime}$ & $1^{\prime}-0^{\prime \prime}$ \\
\hline 5 & $1^{\prime}-9^{\prime \prime}$ & $1^{\prime}-3^{\prime \prime}$ & $1^{\prime}-5^{\prime \prime}$ & : \\
\hline 6 & $2^{\prime}-2^{\prime \prime}$ & $1^{\prime}-6^{\prime \prime}$ & $1^{\prime}-9^{\prime \prime}$ & 1'33"- \\
\hline 7 & $2^{\prime}-8$ & $1^{\prime}-11^{\prime \prime}$ & $2^{\prime}-2^{\prime \prime}$ & $\left(1^{\prime}-7^{n}\right.$ \\
\hline 8 & $3^{\prime}-6^{\prime \prime}$ & $2^{\prime}-6^{\prime \prime}$ & $2-10^{\circ}$ & $2^{\prime}-0^{\circ}$ \\
\hline 9 & $4^{\prime}-6^{\prime \prime}$ & $3^{\prime}-2^{\prime \prime}$ & $3^{\prime}-7^{\prime \prime}$ & $2^{\prime}-7^{\prime \prime}$ \\
\hline 10 & $5^{\prime}-8^{\prime \prime}$ & $4^{\prime}-1^{\prime \prime}$ & $4^{\prime}-6^{\prime \prime}$ & $3^{\prime} \cdot 3^{\prime \prime}$ \\
\hline 11 & $6^{\prime}-11^{\prime \prime}$ & $5^{\prime}-0^{\circ}$ & $5^{\prime}-7^{\prime \prime}$ & $4^{\prime}-0^{\prime \prime}$ \\
\hline 14 & $9^{\prime} \cdot 5^{\prime \prime}$ & $6^{\prime}-9^{\prime \prime}$ & $\tau^{\prime}-7^{\prime \prime}$ & $5^{\prime}-5^{\prime \prime}$ \\
\hline 18 & $12^{\prime}-3^{\prime \prime}$ & $8^{\circ}-9^{\prime \prime}$ & $9^{\prime}-9^{\prime \prime}$ & $7^{\prime}-0^{\alpha}$ \\
\hline
\end{tabular}

Table 5.1-7 - Tension Development Lengths, 4 for Grade 60 Uncoated Bars

\begin{tabular}{|c|c|c|c|c|}
\hline \multirow[b]{2}{*}{$\begin{array}{l}\text { Bar } \\
\text { Size }\end{array}$} & \multicolumn{2}{|c|}{$l_{\mathrm{d}}$} & \multicolumn{2}{|c|}{$\begin{array}{l}\text { Ld Modified for } \\
\text { Bar Spacing Per } \\
\text { Article 8.25.3.1 } \\
\text { (Spacing } 266^{\prime} \text { ) }\end{array}$} \\
\hline & $\begin{array}{l}\text { Top Bars } \\
\text { Ft. - In. }\end{array}$ & $\begin{array}{l}\text { Others } \\
\text { Ft. - In. }\end{array}$ & $\begin{array}{c}\text { Top Bars } \\
\text { Ft. - In. }\end{array}$ & $\begin{array}{l}\text { Others } \\
F_{L}=\mathrm{In} \text {. }\end{array}$ \\
\hline 3 & $1^{\prime}-5^{\prime \prime}$ & $1^{\prime}-0^{\prime \prime}$ & $1^{\prime}-2^{\prime \prime}$ & $1^{\prime}-0^{\prime \prime}$ \\
\hline 4 & $1^{\prime}-5^{\prime \prime}$ & $1^{\prime}-0^{\prime \prime}$ & $1^{\prime}-2^{\prime \prime}$ & $1^{\prime}-0^{\prime \prime}$ \\
\hline 5 & $1^{\prime}-9^{\prime \prime}$ & $1^{\prime}-3^{\prime \prime}$ & $1^{\prime}-5^{\prime \prime}$ & $1^{\prime}-0^{\prime \prime}$ \\
\hline 6 & $2^{\prime}-2^{\prime \prime}$ & $1^{\prime}-6^{\prime \prime}$ & $1^{\prime}-9^{\prime \prime}$ & $1^{\prime} \cdot 3^{\prime \prime}$ \\
\hline 7 & $2^{\prime}-6^{\prime \prime}$ & $1^{\prime}-9^{\prime \prime}$ & $2^{\prime}-0^{*}$ & $1^{\prime}-5^{\prime \prime}$ \\
\hline 8 & $3^{\prime}-2^{\prime \prime}$ & $2^{\prime}-3^{\prime \prime}$ & $2^{\prime}-6^{\prime \prime}$ & $1^{\prime} \cdot 10^{\prime \prime}$ \\
\hline 9 & $4^{\prime}-0^{\prime \prime}$ & $2^{\prime}-10^{\prime \prime}$ & $3^{\prime}-2^{\prime \prime}$ & $2^{\prime}-4^{\prime \prime}$ \\
\hline 10 & $5^{\prime}-1^{\prime \prime}$ & $3^{\prime}-8^{\prime \prime}$ & $4^{\prime}-1^{\prime \prime}$ & $2.11^{\prime \prime}$ \\
\hline 11 & $6^{\prime}-3^{\prime \prime}$ & $4^{\prime}-5^{\prime \prime}$ & $5^{\prime}-0^{\prime \prime}$ & $3^{\prime}-7^{\prime \prime}$ \\
\hline 14 & $8^{\prime}-5^{\prime \prime}$ & $6^{\prime}-1^{\prime \prime}$ & $6^{\prime}-9^{\prime \prime}$ & $4^{\prime}-10^{\prime \prime}$ \\
\hline 18 & $10^{\circ}-11^{\prime \prime}$ & $7^{\prime}-10^{\prime \prime}$ & $8^{\prime}-9^{\prime \prime}$ & $6^{\prime} \cdot 3^{\prime \prime}$ \\
\hline
\end{tabular}

Table 5.1-8 Tension Development Lengths. 4 ,

for Grade 60 Uncoated Bars $f_{c}=6.000$ psi; Normal Weight Concrete

\begin{tabular}{|c|c|c|c|c|}
\hline \multirow[b]{2}{*}{$\begin{array}{l}\text { Bar } \\
\text { Size }\end{array}$} & \multicolumn{2}{|c|}{$l_{\mathrm{d}}$} & \multicolumn{2}{|c|}{$\begin{array}{l}\text { ld Modified for } \\
\text { Bar Spacíng Per } \\
\text { Article } 8.25 .3 .1 \\
\text { (Spacing } \geq 6^{*} \text { ) }\end{array}$} \\
\hline & $\begin{array}{c}\text { Top Bars } \\
\text { FL - In. }\end{array}$ & $\begin{array}{l}\text { Ouhers } \\
\text { FL - In. }\end{array}$ & $\begin{array}{c}\text { Top Bars } \\
\text { Ft. - In. }\end{array}$ & $\begin{array}{l}\text { Others } \\
\mathrm{Ft} \text { - In. }\end{array}$ \\
\hline 3 & $1^{\prime}-5^{\prime \prime}$ & $1^{\prime}-\sigma^{\prime}$ & $1^{\prime}-2^{\prime \prime}$ & $1^{\prime}-0^{\prime \prime}$ \\
\hline 4 & $1^{\prime}-5^{\infty}$ & $1^{\prime}-\sigma^{\circ}$ & $1^{\prime}-2^{\prime \prime}$ & $1^{\prime}-0^{\prime}$ \\
\hline 5 & $1^{\prime}-9^{\prime \prime}$ & $1^{\prime}-3^{\prime \prime}$ & $1^{\prime}-5^{\prime \prime}$ & $\left.1^{\prime}-0^{*}\right)$ \\
\hline 6 & $2^{\prime}-z^{\prime}$ & $1^{\prime}-6^{\prime \prime}$ & $1^{\prime}-9^{\prime \prime}$ & $1^{\prime}-3^{\infty}$ \\
\hline 7 & $2^{\prime}-6^{\prime \prime}$ & $1 ;, 9^{\prime \prime}$ & $2^{\prime}-0^{\circ}$ & $P 5$ \\
\hline 8 & (2-11') & $2-152$ & $6\left(x^{\prime} 4^{4}\right.$ & $(-8$ \\
\hline 9 & $3^{\prime}-8^{\prime \prime}$ & $2^{2}-7 \times 3$ & "2-11" & $2^{\prime}-1^{\prime \prime}$ \\
\hline 10 & $4^{\prime}-8^{\prime \prime}$ & $3^{0}-4^{\prime \prime}$ & $3^{\prime}-8^{\prime \prime}$ & $2^{\prime}-8^{\prime \prime}$ \\
\hline 11 & $5^{\prime}-8^{\prime \prime}$ & $4^{\prime}-1^{\prime \prime}$ & $4^{\prime}-6^{\prime \prime}$ & $3^{\prime}-3^{\prime \prime}$ \\
\hline 14 & $7^{\prime}-9^{\prime \prime}$ & $5^{\prime}-6^{\prime \prime}$ & $6^{\prime}-2^{\prime \prime}$ & $4^{\prime}-5^{\prime \prime}$ \\
\hline 18 & $10^{\circ}-0^{\circ}$ & $\tau^{\prime}-z^{*}$ & $8^{\prime}-0^{\prime \prime}$ & $5^{\prime}-99^{\prime \prime}$ \\
\hline
\end{tabular}

Reference AASHTO Standard Specifications for Highways Bfidges, Interims 1991, Article 8.25. 


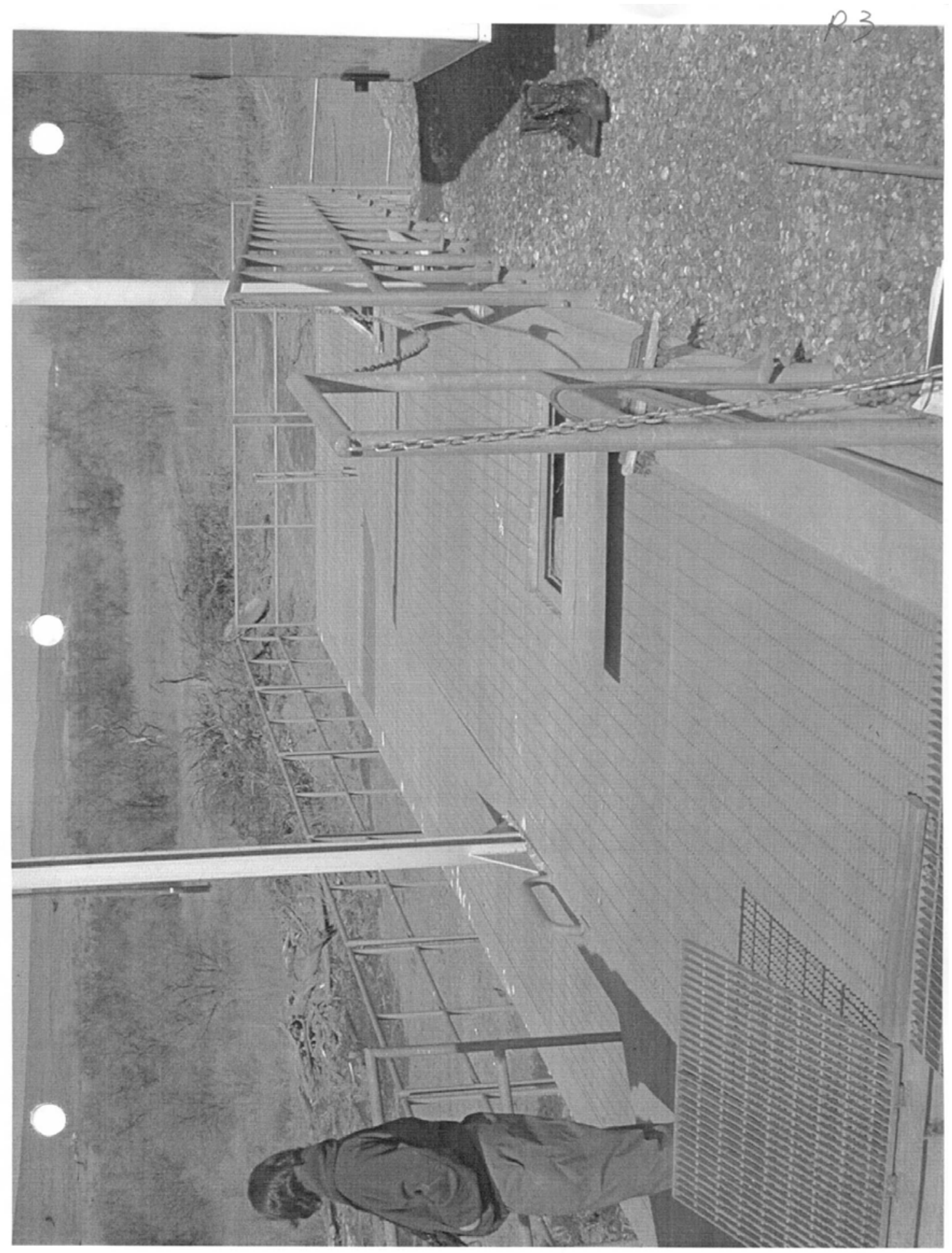




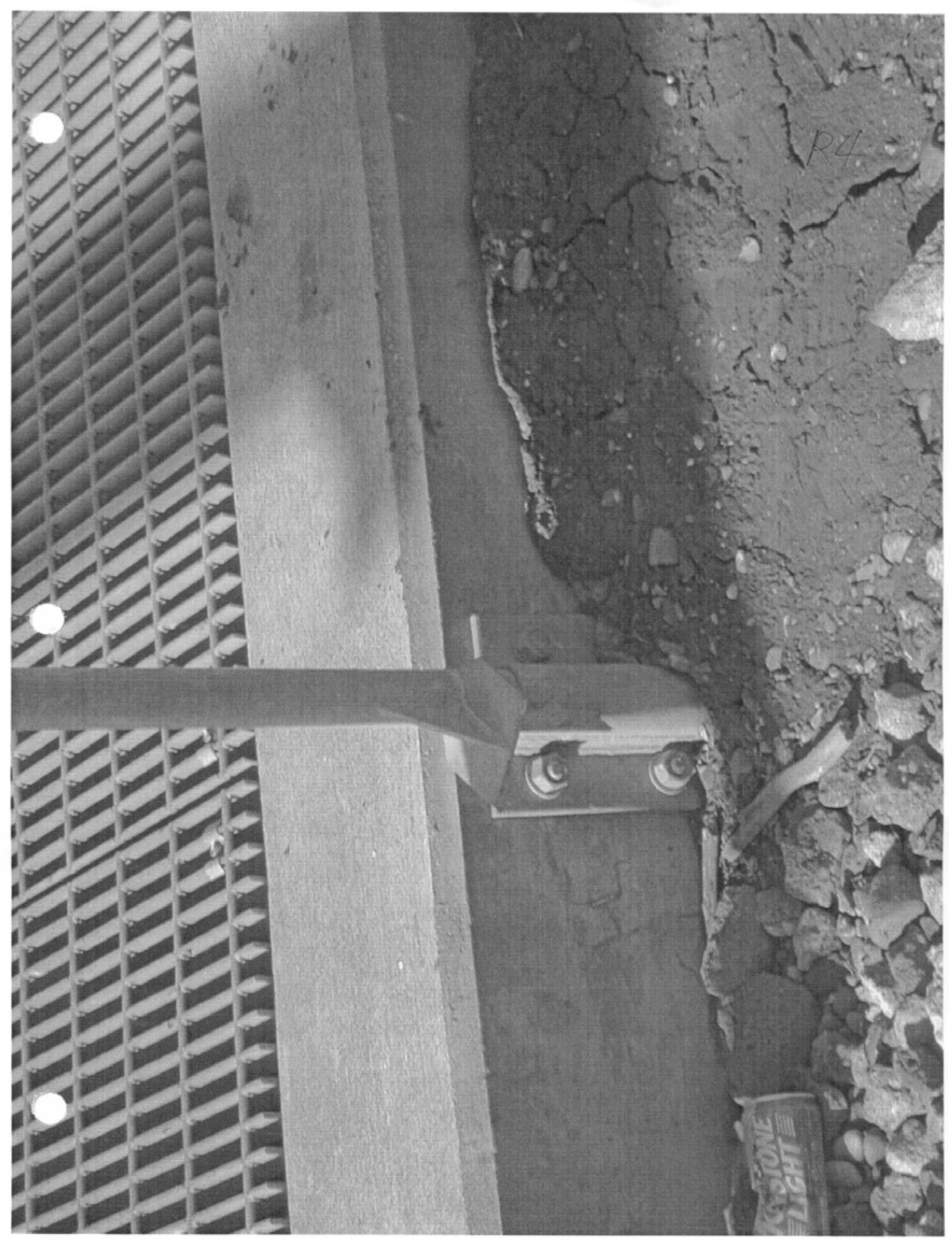


Construction-Design Data

\section{Nelson ${ }^{\circledR}$}

\section{embedment properties of headed studs}

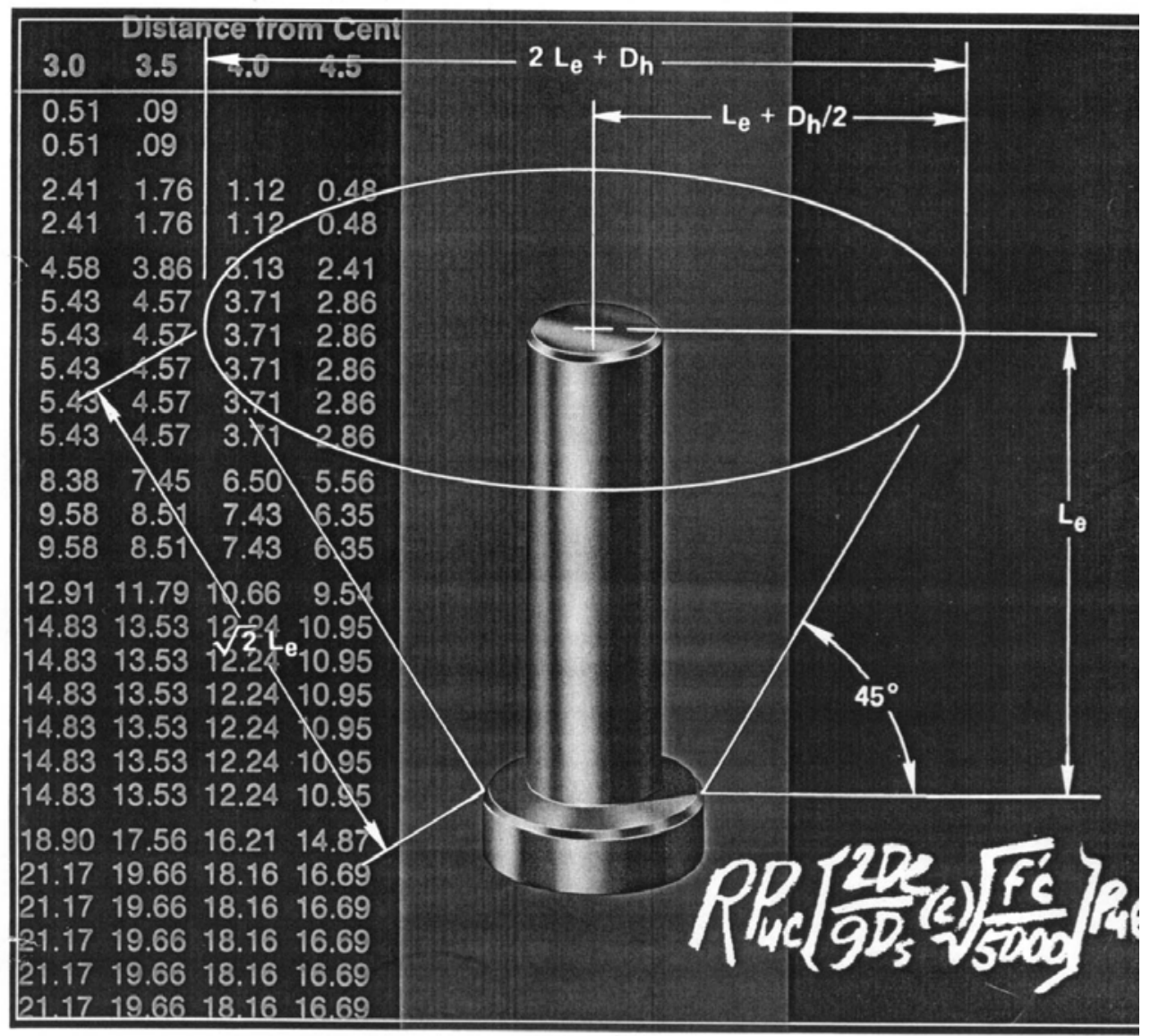


Table 15. Full Embedment Shear Capacities Of Headed Anchors

\begin{tabular}{|c|c|c|c|c|c|c|c|c|c|}
\hline \multirow[b]{2}{*}{$\begin{array}{l}\text { Anchor (1.) } \\
\text { Size }\end{array}$} & \multirow{2}{*}{ 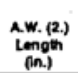 } & \multirow[b]{2}{*}{$\begin{array}{c}\text { H/Ds } \\
\text { (No. of Dis.) }\end{array}$} & \multirow[b]{2}{*}{$\begin{array}{l}\text { sue (3.) } \\
\text { (Kipa) }\end{array}$} & \multicolumn{6}{|c|}{ Conerete sheer Capectly (Suc) Xlos } \\
\hline & & & & \multicolumn{3}{|c|}{ Normal Concrele (145 pef) } & \multicolumn{3}{|c|}{ Lightweight Concrete (110 pel) } \\
\hline $\begin{array}{l}y_{6} \times 2^{11 / 16} \\
y_{6} \times 44_{6}\end{array}$ & ${ }_{4}^{2 \% / 16}$ & $\begin{array}{l}10.25 \\
16.00\end{array}$ & $\begin{array}{l}2.65 \\
2.65\end{array}$ & $\begin{array}{l}2.22 \\
2.22\end{array}$ & $\begin{array}{l}259 \\
259\end{array}$ & $\begin{array}{l}2.65 \\
2.65\end{array}$ & $\begin{array}{l}1.85 \\
1.85\end{array}$ & $\begin{array}{l}2.16 \\
2.16\end{array}$ & $\begin{array}{l}2.41 \\
2.41\end{array}$ \\
\hline $\begin{array}{l}* \times 4 \% \\
x \times 8 \%\end{array}$ & 8 & $\begin{array}{l}10.67 \\
16.00\end{array}$ & $\begin{array}{l}5.96 \\
5.96\end{array}$ & $\begin{array}{l}4.98 \\
4.98\end{array}$ & $\begin{array}{l}5.79 \\
5.79\end{array}$ & $\begin{array}{l}596 \\
596\end{array}$ & $\begin{array}{l}4.14 \\
4.14\end{array}$ & $\begin{array}{l}4.83 \\
4.83\end{array}$ & $\begin{array}{l}5.41 \\
5.41\end{array}$ \\
\hline 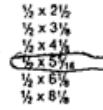 & $\begin{array}{l}2 \\
3 \\
4 \\
4 \% \pi \\
6 \\
8\end{array}$ & $\begin{array}{r}4.00 \\
6.00 \\
8.00 \\
10.37 \\
12.00 \\
16.00\end{array}$ & $\begin{array}{r}10.60 \\
10.60 \\
10.60 \\
-10.80 \\
10.60 \\
10.60\end{array}$ & $\begin{array}{l}8.87 \\
8.87 \\
8.87 \\
8.87 \\
8.87 \\
8.87\end{array}$ & $\begin{array}{c}10.33 \\
10.33 \\
10.23 \\
10.33 \\
10.33 \\
10.33\end{array}$ & $\begin{array}{l}10.60 \\
10.60 \\
10.60 \\
10.60 \\
10.50 \\
10.60\end{array}$ & $\begin{array}{l}7.39 \\
7.39 \\
7.39 \\
7.39 \\
7.39 \\
7.39\end{array}$ & $\begin{array}{l}8.61 \\
8.61 \\
8.61 \\
8.61 \\
8.61 \\
8.61\end{array}$ & $\begin{array}{l}9.64 \\
9.64 \\
9.64 \\
9.64 \\
9.64 \\
9.64\end{array}$ \\
\hline 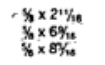 & $\begin{array}{l}21 / 2 \\
6 \% / 6 \\
8\end{array}$ & $\begin{array}{r}4.00 \\
10.20 \\
12.80\end{array}$ & $\begin{array}{l}16.56 \\
16.56 \\
16.56\end{array}$ & $\begin{array}{l}13.89 \\
13.89 \\
13.89\end{array}$ & $\begin{array}{l}16.19 \\
16.19 \\
16.19\end{array}$ & $\begin{array}{l}16.56 \\
1656 \\
16.56\end{array}$ & $\begin{array}{l}11.57 \\
11.57 \\
11.57\end{array}$ & $\begin{array}{l}13.49 \\
13.49 \\
13.49\end{array}$ & $\begin{array}{l}15.10 \\
15.10 \\
15.10\end{array}$ \\
\hline $\begin{array}{r}y_{4} \times 3 y_{16} \\
y_{16} \times 31 y_{16} \\
y_{4} \times 4 y_{16} \\
y_{4} \times 5 y_{16} \\
\frac{y_{4} \times 6 y_{10}}{y_{4} \times 7 y_{16}} \\
y_{4} \times 8 y_{16}\end{array}$ & $\begin{array}{l}3 \\
31 / 2 \\
4 \\
5 \\
6 \\
7 \\
8\end{array}$ & $\begin{array}{r}4.00 \\
4.67 \\
5.33 \\
6.02 \\
9.00 \\
9.33 \\
10.67\end{array}$ & 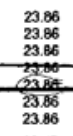 & $\begin{array}{r}19.99 \\
19.99 \\
19.99 \\
-1990 \\
19.99 \\
19.99 \\
19.99\end{array}$ & $\begin{array}{l}23.3 \\
23.3 \\
23.3 \\
25.3 \\
20.3 \\
23.3 \\
23.3\end{array}$ & $\begin{array}{l}23.86 \\
23.36 \\
23.86 \\
23.86 \\
22.86 \\
23.86 \\
23.86\end{array}$ & $\begin{array}{l}16.67 \\
16.67 \\
16.67 \\
16.67 \\
16.67 \\
16.67 \\
16.67\end{array}$ & $\begin{array}{l}19.42 \\
19.42 \\
19.42 \\
19.42 \\
19.42 \\
19.42 \\
19.42\end{array}$ & $\begin{array}{l}21.73 \\
21.73 \\
21.73 \\
21.73 \\
21.73 \\
21.73 \\
21.73 \\
\end{array}$ \\
\hline 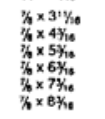 & $\begin{array}{l}31 / 2 \\
4 \\
5 \\
6 \\
7 \\
8\end{array}$ & $\begin{array}{l}4.00 \\
4.57 \\
5.71 \\
6.86 \\
8.00 \\
9.14\end{array}$ & $\begin{array}{l}32.47 \\
32.47 \\
32.47 \\
32.47 \\
32.47 \\
32.47\end{array}$ & $\begin{array}{l}27.19 \\
27.19 \\
27.19 \\
27.19 \\
27.19 \\
27.19\end{array}$ & $\begin{array}{l}31.69 \\
31.69 \\
31.69 \\
31.69 \\
31.69 \\
31.69\end{array}$ & $\begin{array}{r}32.47 \\
32.47 \\
32.47 \\
32.47 \\
32.47 \\
: 32.47\end{array}$ & $\begin{array}{l}22.66 \\
22.66 \\
22.66 \\
22.68 \\
22.66 \\
22.68\end{array}$ & $\begin{array}{l}26.41 \\
26.41 \\
26.41 \\
26.41 \\
26.41 \\
26.41\end{array}$ & $\begin{array}{l}29.55 \\
29.55 \\
29.55 \\
29.55 \\
29.55 \\
29.55\end{array}$ \\
\hline NOTES (1.) & ingth & A After Welding & & & (3) Sue = UI & $\begin{array}{l}\text { ale Stud } \\
.9 \mathrm{As}_{\mathrm{s}} \mathrm{s} \text {. }\end{array}$ & uc > Sue. & $\begin{array}{l}\text { r Strength } \\
\text { Sue Controls }\end{array}$ & \\
\hline
\end{tabular}

2 Spacing For Development of Full Shear Capacity.

There are two basic failure modes for studs bject to pure shear forces. In the first, the ncrete capacity exceeds the anchor capacity and failure occurs in the anchor. The second failure mode occurs when the anchor capacity exceeds the concrete capacity. From the Ollgaard. Slutter and Fisher investigation 19.1 , failure occurs in a wedge shaped section pulled from the concrete and is preceeded by localized crushing ahead of the stud, bending in the stud and cracking extending at an angle from under the stud head behind the stud to the concrete steel interface.

This failure is somewhat different from the large conical type failures that occur in tension loading, and is relatively unaffected by stud length or stud spacing as compared with tension loading.
Spacing to develop full shear capacity is influenced by the following factors with Case $\mathrm{B}$. assuming higher relative importance.

A. Spacing between anchors in a group or with regard to boundary conditions on anchors without a free edge in the direction of the shear force.

B. Spacing between anchors and distance from a free edge of anchors at an edge subject to shear force.

As long as the anchor has no free edge in the direction of the shear force, Case $A$. applies, and spacings are governed by the $H / D$ s ratio. A spacing equal to the ratio of 4.0 is satisfactory to develop the full potential shear capacity of a headed anchor. Table 16., which follows, shows the fuli spacing requirements.

Free edge conditions in the direction of the shear force are covered in Section 5.3.2. 
FLEXURE 8.6.1-Design moment strength $\phi M_{n}$ for slab sections 12 in. wide Reference: ACI 318-83, Sections 7.12, 8.4.1, 8.4.3, 9.3.2, 10.2, 10.3.1-10.3.3, 10.5.1, and 10.5.3, and Commentary Sections 10.3.1(A)(1) and 10.3.2

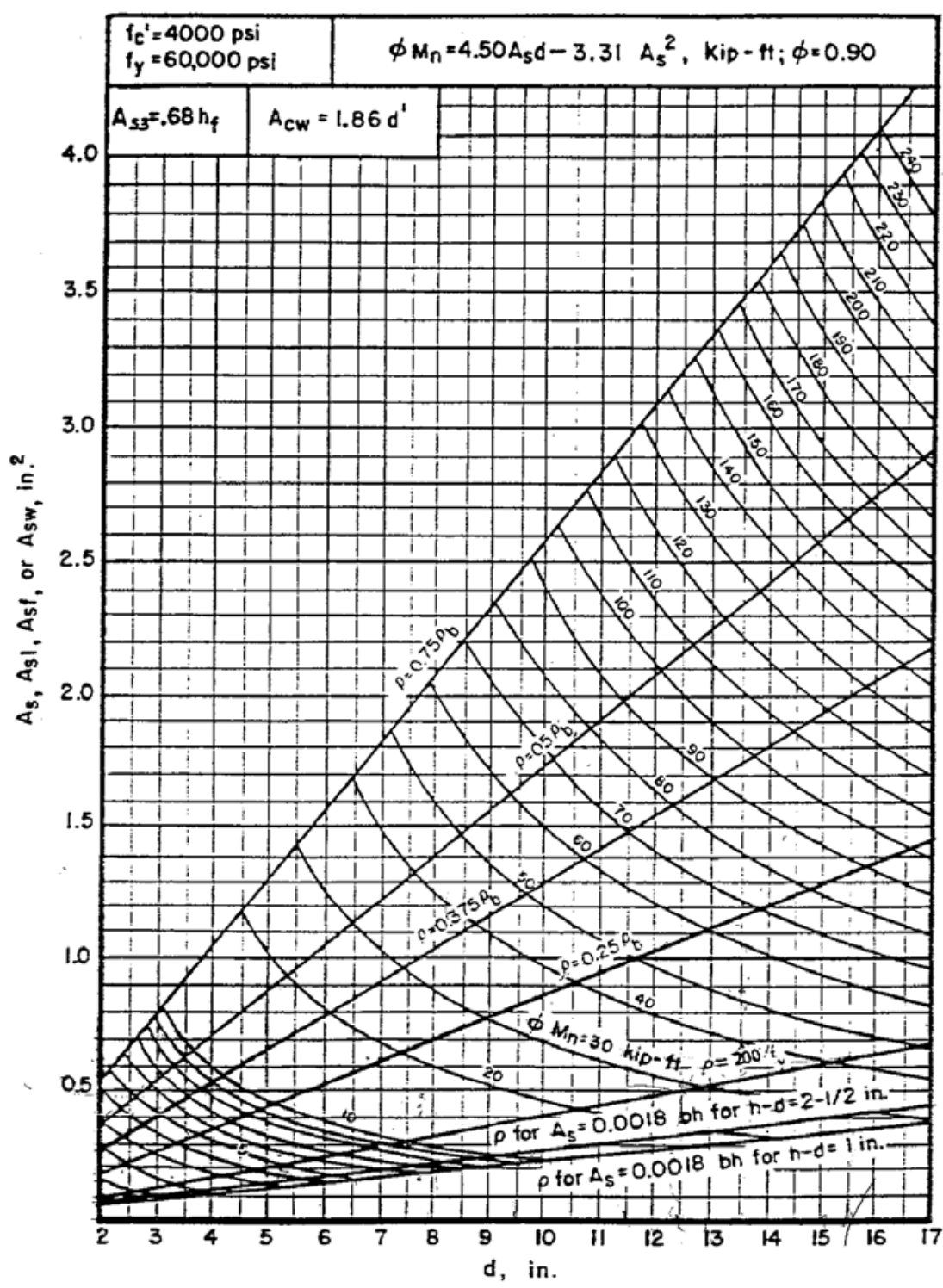

For use of this Design Aid, see Fiexure Examples 1, 2. 4, 5 , and 11- 15 .

194

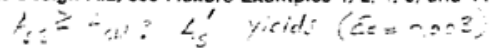


- Whenever reinforcement continuity is required, lapped splices should be used. The length of lap splices varies with concrete strength, type of concrete, bar grades, size, surface geometry, spacing, and concrete cover. Details of lapped splices should be in accordance with the project specifications. Mechanical connections are not yet available.

\section{3-Quality control and inspection}

Quality control should be carried out by lot testing of FRP

bars. The manufacturer should supply adequate lot or production run traceability. Tests conducted by the manufacturer or a third-party independent testing agency can be used.

All tests should be performed using the recommended test methods cited in the literature. Material characterization tests that include the following properties should be performed at least once before and after any change in manufacturing process, procedure, or materials:

- Tensile strength, tensile modulus of elasticity, and ultimate strain;

- Fatigue strength:

- Bond strength;

- Coefficient of thermal expansion; and

- Durability in alkaline environment.

To assess quality control of an individual lot of FRP bars, it is recommended to determine tensile strength, tensile modulus of elasticity, and ultimate strain. The manufacturer should furnish upon request a certificate of conformance for any given lot of FRP bars with a description of the test protocol.

\section{PART 4-OESIGN RECOMMENDATIONS}

\section{CHAPTER 7-GENERAL DESIGN} CONSIDERATIONS

The general design recommendations for flexural concrete elements reinforced with FRP bars are presented in this chapter. The recommendations presented are based on principles of equilibrium and compatibility and the constitutive laws of the materials. Furthermore, the brittle behavior of both FRP reinforcement and concrete allows consideration to be given to either FRP rupture or concrete crushing as the mechanisms that control failure.

\section{1-Design philosophy}

Both strength and working stress design approaches were considered by this committee. The committee opted for the strength design approach of reinforced concrete members reinforced with FRP bars to ensure consistency with other ACI documents. In particular, this guide makes reference to provisions as per ACl 318-95, "Building Code Requirements for Structural Concrete and Commentary." These design recommendations are based on limit states design principles in that an FRP reinforced concrete member is designed based on its required strength and then checked for fatigue endurance, creep rupture endurance, and serviceability criteria. In many instances, serviceability criteria or fatigue and creep rupture endurance limits may control the design of concrete members reinforced for flexure with FRP bars (especially aramid and glass FRP that exhibit low stiffness).
The load factors given in ACI 318 are used to determine the required strength of a reinforced concrete member.

\section{2-Design material properties}

The material properties provided by the manufacturer, such as the guaranteed tensile strength, should be considered as initial properties that do not include the effects of long. term exposure to the environment. Because long-term exposure to various types of environments can reduce the tensile strength and creep rupture and fatigue endurance of FRP bars, the material properties used in design equations should be reduced based on the type and level of environmental exposure.

Equations (7-1) through (7-3) give the tensile properties that should be used in all design equations. The design tensile strength should be determined by

$$
f_{f u}=C_{E} f_{f u}^{*}
$$

where

$f_{f u}=$ design tensile strength of FRP, considering reductions for service environment, psi;

$C_{E}=$ environmental reduction factor, given in Table 7.1 for various fiber type and exposure conditions; and

$f_{f u}=$ guaranteed tensile strength of an FRP bar defined as the mean tensile strength of a sample of test specimens minus three times the standard deviation $\left(f_{f u}^{*}\right.$ $\left.=f_{\text {u.ave }}-3 \sigma\right)$, psi.

The design rupture strain should be determined as

$$
\varepsilon_{j u}=C_{E} \varepsilon_{f u}^{*}
$$

where

$\varepsilon_{f u}=$ design rupture strain of FRP reinforcement; and

$\varepsilon_{f u}=$ guaranteed rupture strain of FRP reinforcement defined as the mean tensile strain at failure of a sam. ple of test specimens minus three times the standard deviation $\left(\varepsilon_{f u}^{*}=\varepsilon_{u, a v e}-3 \sigma\right)$.

The design modulus of elasticity will be the same as the value reported by the manufacturer.

The environmental reduction factors given in Table 7.1 are conservative estimates depending on the durability of each fiber type and are based on the consensus of Committee 440. Temperature effects are included in the $C_{E}$ values. FRP bars, however, should not be used in environments with a service temperature higher than the $T_{g}$ of the resin used for their manufacturing. It is expected that with continued research, these values will become more reflective of actual effects of environment. The methodology regarding the use of these factors, however, is not expected to change.

7.2.1 Tensile strength of FRP bars at bends--The design tensile strength of FRP bars at a bend portion can be determined as

$$
f_{f b}=\left(0.05 \cdot \frac{r_{b}}{d_{b}}+0.3\right) f_{f u} \leq f_{f u}
$$


Table 7.1-Environmental reduction factor for various fibers and exposure conditions

\begin{tabular}{c|c|c}
\hline Exposure condition & Fiber type & $\begin{array}{c}\text { Environmental } \\
\text { reduction factor } C_{E}\end{array}$ \\
\hline \multirow{2}{*}{$\begin{array}{c}\text { Concrete not exposed to earth } \\
\text { and weather }\end{array}$} & Carbon & 1.0 \\
\cline { 2 - 3 } & Glass & 0.8 \\
\hline \multirow{3}{*}{$\begin{array}{c}\text { Concrete exposed to earth and } \\
\text { weather }\end{array}$} & Aramid & 0.9 \\
\cline { 2 - 3 } & Carbon & 0.9 \\
\cline { 2 - 3 } & Glass & 0.7 \\
\hline
\end{tabular}

where

$f_{f b}=$ design tensile strength of the bend of FRP bar, psi;

$r_{b}=$ radius of the bend, in .

$d_{b}=$ diameter of reinforcing bar, in.; and

$f_{f u}=$ design tensile strength of FRP, considering reductions for service environment, psi.

Equation (7-3) is adapted from design recommendations by the Japan Society of Civil Engineers (1997b). Limited research on FRP hooks (Ehsani, Saadatmanesh, and Tao 1995) indicates that the tensile force developed by the bent portion of a GFRP bar is mainly influenced by the ratio of the bend radius to the bar diameter, $r_{b} / d_{b}$, the tail length, and to a lesser extent, the concrete strength.

For an altemative determination of the reduction in tensile strength due to bending, manufacturers of bent bars may provide test results based on test methodologies cited in the literature.

\section{CHAPTER 8-FLEXURE}

The design of FRP reinforced concrete members for flexure is analogous to the design of steel-reinforced concrete members. Experimental data on concrete members reinforced with FRP bars show that flexural capacity can be calculated based on assumptions similar to those made for members reinforced with steel bars (Faza and GangaRao 1993; Nanni 1993b; GangaRao and Vijay 1997a). The design of members reinforced with FRP bars should take into account the mechanical behavior of FRP materials.

\section{1-General considerations}

The recommendations given in this chapter are only for rectangular sections, as the experimental work has almost exclusively considered members with this shape. In addition, this chapter refers only to cases of rectangular sections with a single layer of one type of FRP reinforcement. The concepts described here, however, can also be applied to the analysis and design of members with different geometry and multiple types, multiple layers, or both, of FRP reinforcement. Although there is no evidence that the flexural theory, as developed here, does not apply equally well to nonrectangular sections, the behavior of nonrectangular sections has yet to be confirmed by experimental resuits.

8.1.1 Flexural design philosophy-Steel-reinforced concrete sections are commonly under-reinforced to ensure yielding of steel before the crushing of concrete. The yielding of the steel provides ductility and a warning of failure of

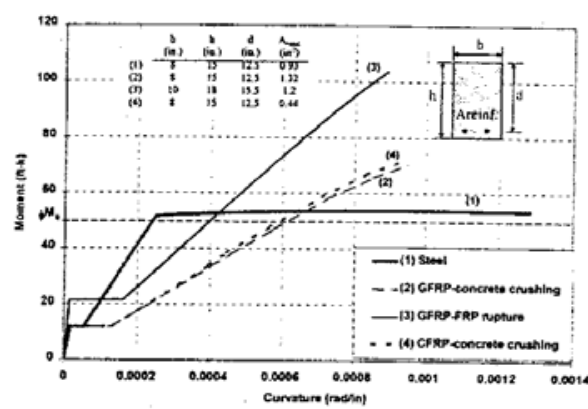

Fig. 8.I-Theoretical moment-curvature relationships for reinforced concrete sections using steel and FRP bars.

the member. The nonductile behavior of FRP reinforcement necessitates a reconsideration of this approach.

If FRP reinforcement ruptures, failure of the member is sudden and catastrophic. There would be limited warning of impending failure in the form of extensive cracking and large deflection due to the significant elongation that FRP reinforcement experiences before rupture. In any case, the member. would not exhibit ductility as is commonly observed for under-reinforced concrete beams reinforced with steel rebars.

The concrete crushing failure mode is marginally more desirable for flexural members reinforced with FRP bars (Nanni 1993b). By experiencing concrete crushing, a flexural member does exhibit some plastic behavior before failure.

In conclusion, both failure modes (FRP rupture and concrete crushing) are acceptable in goveming the design of flexural members reinforced with FRP bars provided that strength and serviceability criteria are satisfied. To compen sate for the lack of ductility, the member should possess a higher reserve of strength. The suggested margin of safety against failure is therefore higher than that used in traditional steel-reinforced concrete design.

Experimental resuits (Nanni 1993b; Jaeger, Mufti, and Tadros 1997; GangaRao and Vijay 1997a; Theriault and Benmokrane 1998) indicated that when FRP reinforcing bars ruptured in tension, the failure was sudden and led to the collapse of the member. A more progressive, less catastrophic failure with a higher deformability factor was observed when the member failed due to the crushing of concrete. The use of high-strength concrete allows for better use of the highstrength properties of FRP bars and can increase the stiffness of the cracked section, but the brittleness of high-strength concrete, as compared to normal-strength concrete, can reduce the overall deformability of the flexural member.

Figure 8.1 shows a comparison of the theoretical momentcurvature behavior of beam cross sections designed for the same strength $\phi M_{n}$ following the design approach of $\mathrm{ACI}$ 318 and that described in this chapter (including the recommended strength reduction factors). Three cases are presented in addition to the steel reinforced cross section: two sections reinforced with GFRP bars and one reinforced with 
I. Tensile Stress, Nominal Diameter \& Cross Sectional Area, Modulus of Elasticity:

\begin{tabular}{|c|c|c|c|c|c|c|c|c|c|}
\hline Bar & Size & $\begin{array}{l}\text { Cross } \\
\text { Sectional } \\
\text { Area }\end{array}$ & & Nominal & Dia. & Tensile & Strength & & Elasticity \\
\hline $\mathrm{mm}$ & inches & $\mathrm{mm} 2$ & in2 & $\mathrm{mm} 2$ & in 2 & $\mathrm{MPa}$ & $\mathrm{ksi}$ & $\mathrm{GPa}$ & psi 106 \\
\hline 6 & $\$ 2$ & 33.23 & 0.0515 & 6.35 & 0.25 & 825 & 120 & 40.8 & 5.92 \\
\hline 9 & $\# 3$ & 84.32 & 0.131 & 9.53 & 0.375 & 360 & 110 & 40.8 & 5.92 \\
\hline 12 & $\# 4$ & 144.85 & 0.224 & 12.70 & 0.5 & 690 & 100 & 40.8 & 5.92 \\
\hline 16 & $\# 5$ & 217.56 & 0.337 & 15.88 & 0.625 & 655 & 95 & 40.8 & 5.92 \\
\hline 19 & $\# 6$ & 295.50 & 0.458 & 19.05 & 0.75 & 620 & 90 & 40.8 & 5.92 \\
\hline 22 & $\# 7$ & 382.73 & 0.593 & 22.23 & 0.875 & 586 & 85 & 40.8 & 5.92 \\
\hline 25 & $\$ 8$ & 537.90 & 0.834 & 25.4 & 1 & 550 & 80 & 40.8 & 5.92 \\
\hline 32 & $\# 10$ & 807.34 & 1.251 & 31.75 & 1.25 & 517 & 75 & 40.8 & 5.92 \\
\hline
\end{tabular}

Hughes Brothers reserves the right to make improvements in the product and/or proces herin is on changes to some physical-mechanical characteristics. The d herin is considered representative of current production and is believed to be relia the best available characterization of the product as of January, 2000

\section{Cross Sectional Area}

The cross sectional area of the rebar may be determined by immersing a sample in water and measuring the volume displacement of the piece. Cross sectional area may also be calculated using the nominal diameter. When calculating the cross sectional area, the cross section is assumed to be a circle.

\section{Nominal Diameter}

The nominal diameter of the rebar is the average diameter and assumes the shape of the rebar is a circle.

\section{Tensile Strength}

Tensile strength values shown are determined as the average failure load divided by the cross sectional area based on nominal bar diameter. Tensile stress varies as diameter increases due to shear lag which develops between the fibers in the larger sizes.

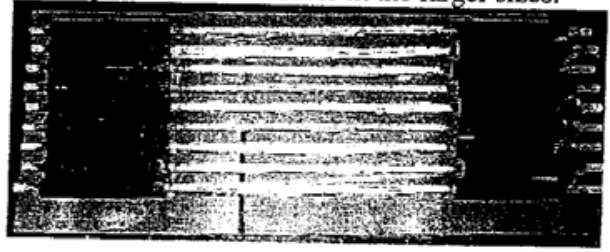

Results of destructive tensile testing performed at Penn State University

\section{Typical Stress/Strain Curve for GFRP Rebar}




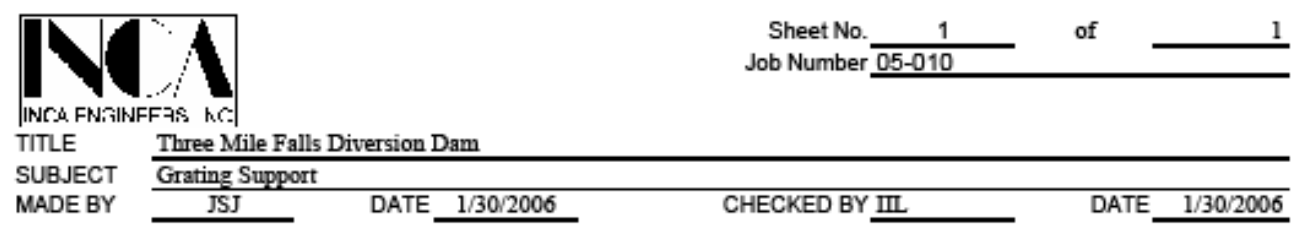

The existing steel grating over the ladder is supported by steel beams. The construction drawings provided by the client do not explicitly show the orientation, spacing or size of these support members.

Per the field visit photos, the bearing bars of the grating run cross-wise with the fish ladder.

Per a design document related to this project, the design load for the existing steel grating is 150 psf uniform live load or $1,000 \mathrm{lb}$ point load.

As a worst case scenario, assume that the main support for the grating runs longitudinal with the grating with a single beam located half way between the ladder side walls. An angle bracket most-likely supports the grating where it meets the side walls of the ladder. To be conservative, this angle will be ignored.

This beam will be interupted by the demolition work as well as by the installation of the new weir cap beams.

Where the beam is interupted, the structural element will be cleanly cut, an end plate welded to the beam, and holes drilled for securing the end plate to the cap beam via F-42 threaded inserts cast into the cap beam.

Assume the beam span between supports is presently 10 feet. (The spacing between the weirs.)

(The beam span wil be reduced by approximately 1.5 feet due to the width of the new cap beam.)

The grating area between supports is

68 SF

Resulting Live Load =

$10,200 \mathrm{lb}$

Assume half of the resulting live load must be carried by the new connection, $4-1 / 2^{2}$ diam $\times 41 / 8^{\prime \prime}$ Nelson studs, and (2) 5/8' diam. bolt(s). (The other half of the load goes to the other end of the support beam and whatever presently supports it.)

Number of bolts per connection

Shear load per threaded cap bolt

2

2.6 kips

A307 galvanized cap bolts wi be used

From AISC Table 1-D, the allowable shear (in KIPS) for threaded parts in single shear is as follows:

\begin{tabular}{cc} 
Size & Allowable Shear \\
\hline $5 / 8$ & 3.1 \\
$3 / 4$ & 4.4
\end{tabular}

A pair of $5 / 8$ " bolts will suffice.

Four Nelson studs wil be welded to a rectangular base plate cast onto the faces of the cap beam at mid-span. The Nelson studs will be located/separated vertically to avoid conflicts with the reinforcing.

The vertical separation between Nelson Studs can be 3.5 inches without interfering with the horizontal \#5 reinforcing. (See New Weir.dgn model - weir section) 


\begin{tabular}{|c|c|c|c|c|c|}
\hline & & & & \multirow[t]{2}{*}{$\begin{array}{l}\text { Sheet No. } \frac{1}{05-010} \\
\text { Job Number }\end{array}$} & \multirow[t]{2}{*}{ of } \\
\hline TITLE & \multirow{2}{*}{\multicolumn{5}{|c|}{$\begin{array}{l}\text { Three Miles Falls Dam PIT Tag } \\
\text { Water Level in Fish Ladder }\end{array}$}} \\
\hline SUBJECT & & & & & \\
\hline MADE BY & \multicolumn{5}{|c|}{$\begin{array}{l}\text { Water Level in Fish Ladder } \\
\text { JSJ }\end{array}$} \\
\hline \multicolumn{6}{|c|}{ From Designer's Operating Criteria dated 06-17-94 } \\
\hline Flow & ondition & $\begin{array}{l}\text { Headwater } \\
\text { Elevation }\end{array}$ & $\begin{array}{l}\text { Tailwater } \\
\text { Elevation }\end{array}$ & & \\
\hline & Flow & 405.47 & 395.23 & & \\
\hline Winte & High Flow & 405.12 & 395.06 & & \\
\hline & Flow & 404.78 & 394.79 & & \\
\hline & Flow & 404.30 & 394.67 & & \\
\hline
\end{tabular}

These calculations account for the variation in the water depth at each weir slot and qunatify the flow and water depth at each weir.

Headwater Elevation $\quad 405.47$

\section{Weir \#10/\#9}

Distance from grade break

Floor elevation at slot

Water depth (just upstream)

U/S Pool elevation

Flow through slot

Head loss at slot

Top of weir elevation

\section{Weir \#9/\#8}

Distance from grade break

Floor elevation at slot

Water depth (just upstream)

U/S Pool elevation

Flow through slot

Head loss at slot

Top of weir elevation

\section{Weir \#8/\#7}

Distance from grade break

Floor elevation at slot

Water depth (just upstream)

U/S Pool elevation

Flow through slot

Head loss at slot

Top of weir elevation
$40.15 \mathrm{ft}$ (grade break at pool 5)

$398.285 \mathrm{ft}$ (1V:10H floor slope)

$7.205 \mathrm{ft}$

$405.47 \mathrm{ft}$

cfs (from discharge function)

$0.5 \mathrm{ft}$

$406.5 \mathrm{ft}$ (from as-builts $30-100-5603$ )

$30.25 \mathrm{ft}$ (grade break at pool 5)

$397.275 \mathrm{ft}$ (1V:10H floor slope)

$6.705 \mathrm{ft}$

$404.97 \mathrm{ft}$

cfs (from discharge function)

$0.5 \mathrm{ft}$

$406.5 \mathrm{ft}$ (from as-builts $30-100-5603$ )

$20.1 \mathrm{ft}$ (grade break at pool 5)

$396.2575 \mathrm{ft}$ (1V:10H floor slope)

$397.275 \mathrm{ft}$

$404.47 \mathrm{ft}$

cfs (from discharge function)

$0.5 \mathrm{ft}$

$405.5 \mathrm{ft}$ (from as-builts $30-100-5603$ ) 


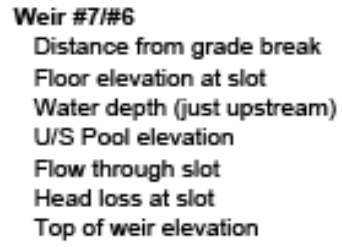

\section{Weir \#4/\#3}

Distance from grade break

Floor elevation at slot

Water depth (just upstream)

U/S Pool elevation

Flow through slot

Head loss at slot

Top of weir elevation
$9.9 \mathrm{ft}$ (grade break at pool 5)

$395.24 \mathrm{ft}$ (1V:10H floor slope)

$10.23 \mathrm{ft}$

$403.97 \mathrm{ft}$

cfs (from discharge function)

$0.5 \mathrm{ft}$

$404.5 \mathrm{ft}$ (from as-builts $30-100-5603$ )

$0.0 \mathrm{ft}$ (grade break at pool 5)

$394.25 \mathrm{ft}$ ( $1 \mathrm{~V}: 10 \mathrm{H}$ floor slope)

$11.22 \mathrm{ft}$

$403.47 \mathrm{ft}$

cfs (from discharge function)

$0.5 \mathrm{ft}$

$403.5 \mathrm{ft}$ (from as-builts $30-100-5603$ )

$10.45 \mathrm{ft}$ (grade break at pool 5)

$393.205 \mathrm{ft}$ (1V:10H floor slope)

$12.265 \mathrm{ft}$

$402.97 \mathrm{ft}$

cfs (from discharge function)

$0.5 \mathrm{ft}$

$403.5 \mathrm{ft}$ (from as-builts $30-100-5603$ )

$20.9 \mathrm{ft}$ (grade break at pool 5)

$392.16 \mathrm{ft}$ (1V:10 $\mathrm{H}$ floor slope)

$13.31 \mathrm{ft}$

$402.47 \mathrm{ft}$

cfs (from discharge function)

$0.5 \mathrm{ft}$

$403.5 \mathrm{ft}$ (from as-builts $30-100-5603$ ) 
MN

TITLE Three Mile Falls Diversion Dam - Existing Weir Elevations

SUBJECT (Based on Ready for Construction Drawings)

MADE BY JSJ DATE

These calculations define height of the clear opening of the antennas.

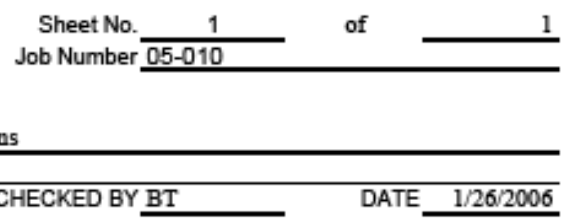

New Wier \#1

Distance from grade break to downstream face of weir
Small (left) weir panel
8.56 feet

Large (right) weir panel

10 feet

New Wier \#2

Distance from grade break to downstream face of weir
Small (left) weir panel
28.56 feet
Large (right) weir panel
30 feet

Grating elevation at grade break

Ladder floor elevation at grade break

404.00 feet (Plan 5603)

394.25 feet (Sect L 5608)

9.75 feet

$\left(g^{\prime}-g^{\prime \prime}\right)$

References to Ready for

Construction Drawing (typical)

The slope of the existing fish lader floor and grating is $1 \mathrm{~V}: 10 \mathrm{H}$

New Weir \#1

Elevation of existing grating finish grade directly above downstream face of weir panels
Small (left) weir panel
404.86 feet
Large (right) weir pane
405.00 feet

Elevation at floor of fish ladder where face of weir panel meets the floor of the fish ladder

Small (left) weir panel

Large (right) weir panel

395.11 feet

395.25 feet

Top elevation of existing weir panels

404.5 feet (Plan 5603)

New Weir \#2

Elevation of existing grating finish grade directly above downstream face of weir panels
Small (left) weir panel
406.86 feet

Large (right) weir panel

407.00 feet

Elevation at floor of fish ladder where face of weir panel meets the floor of the fish ladder

Small (left) weir panel

397.11 feet

Large (right) weir panel

397.25 feet

Top elevation of existing weir panels

406.5 feet (Plan 5603) 
MN

TITLE Three Mile Falls Diversion Dam - Existing Weir Elevations

SUBJECT (Based on Ready for Construction Drawings)

MADE BY JSJ DATE $1 / 26 / 2006$

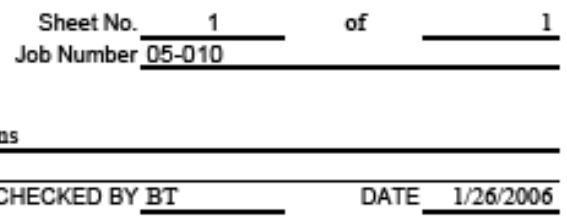

Antennas:

The antenna shall be fabricated so that the top of the antenna shall be

4 inches

below the top of the existing slot/ weir panels

The antennas shall be identical at each of the two locations

Antenna \#1

Elevation of top surface of antenna

height of horizontal legs of antenna

Elevation of floor of ladder

Height of clear opening of antenna

Antenna \#2

Elevation of top surface of antenna

height of horizontal legs of antenna

Elevation of floor of ladder

Height of clear opening of antenna

\author{
404.17 feet \\ 10 inches \\ 395.25 feet \\ 8.08 feet \\ $\left(8^{\prime}-1^{\prime \prime}\right)$ \\ 406.17 feet \\ 10 inches \\ 397.25 feet \\ 8.08 feet
}

Antenna hold-down drop-in anchor elevation

The antenna hold-down strut/mechanism will be installed level in the opening in the cap beam.

The vertical difference between the screw pad surface and the

center of the holes in the end plates is

3 inches

Vertical distance above floor of recess to

center of the holes in the end plates is

10.0 feet

Height of Antenna Guide Fiberglass Pieces

(For New Weir \#2)

Horizontal distance from grade break $\quad 26.8$ feet (measured from demo plan cadd model)

Elevation of bottom of guides

7.28 feet (elevation of top edge of recess in floor)

Elevation of line where right panel meets underside of

CIP cap beam

405.86 feet

Difference $\quad 8.58$ feet

$$
\left(8^{\prime \prime}-6^{\prime \prime}\right)
$$

Fastener Spacing

7 (a)

\begin{tabular}{|c|c|}
\hline & cumulative \\
\hline 8 & 8 \\
\hline 12 & 92 \\
\hline 9 & 101 \\
\hline
\end{tabular}




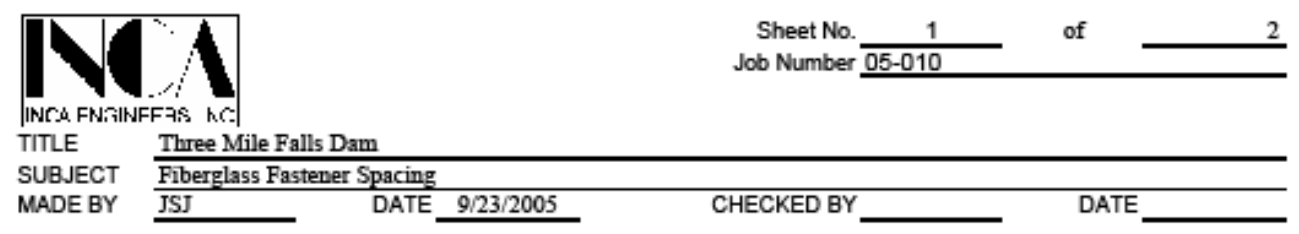

These calculations apply to the allowable shear to secure the fasteners used with the fiberglass antenna guide pieces.

On 9/23/05 I spoke with Ethan Love of Fibergrate at (254) 977-1310. Ethan has assisted with the fiberglass design and fabrication for previous INCA PIT tag projects. Ethan provided the following guidance for designing fasteners for securing the downstream Fiberglass guide to the precast concrete:

$\begin{array}{lr}\text { Eor fiberalass material: } & \\ \text { Ultimate shear } & 4,500 \text { psi in-plane } \\ \text { Ult. Bearing stress } & \text { 30,000 psi } \\ \text { Edge spacing } & \text { 4d } \\ \text { Spacing } & \text { 5d }\end{array}$

We will require that some fasteners be countersunk into the face of the fiberglass guides. Countersinking is necessary to prevent the antenna from hanging up on the fasteners when lowered into position.

Depth of recess to top of countersink

0.05 inch

Per Ethan, I can use $1 / 2$ of the cross section area of the countersink plus the diameter $x$ depth for the remainder of the hole to give the effective shear bearing area.

Thickness of fiberglass piece

Safety Factor

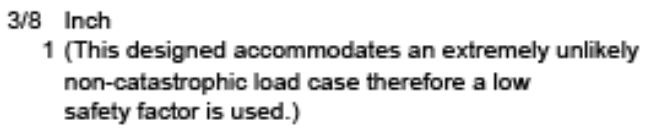

McMaster - Carr makes a 18-8 stainless steel phillips undercut flat head machine screw in 1/4" - 20 size. This fastener requires a minimal depth of countersink.

The bearing area to be used for calculating the shear for this fastener in 0.375 inch thick material is:

$\begin{array}{lc}\text { Countersunk area } & 0.0359 \mathrm{in}^{2} \\ \text { Hole / shaft area } & 0.0545 \mathrm{in}^{2} \\ \text { Ultimate shear force } & 325.9 \mathrm{lbs} \\ \text { Allowable Shear Force } & 325.9 \mathrm{lbs}\end{array}$

McMaster - Carr also makes a 18-8 stainless steel phillips undercut flat head machine screw in $3 / 8^{\prime \prime}$ - 16 size.

The bearing area to be used for calculating the shear for this fastener in $3 / 8^{\prime \prime}$ thick material is:

$\begin{array}{lc}\text { Countersunk area } & 0.0729 \mathrm{in}^{2} \\ \text { Hole / shaft area } & 0.0615 \mathrm{in}^{2} \\ \text { Ultimate shear force } & 440.8 \mathrm{lbs} \\ \text { Allowable Shear Force } & 440.8 \mathrm{lbs}\end{array}$

Check the shear of the SS fastener to see if that governs. Ultimate shear stress on 18-8 stainless fastener (anealed) Allowable shear force on $3 / 8$ " diam $18-8$ stainless fastener Allowable shear force on 1/4" diam 18-8 stainless fastener Clearly the strength of the fiberglass controls.

$$
\begin{aligned}
27,000 & \text { psi } \\
2,982 & \text { lbs } \\
5,301 & \text { lbs }
\end{aligned}
$$




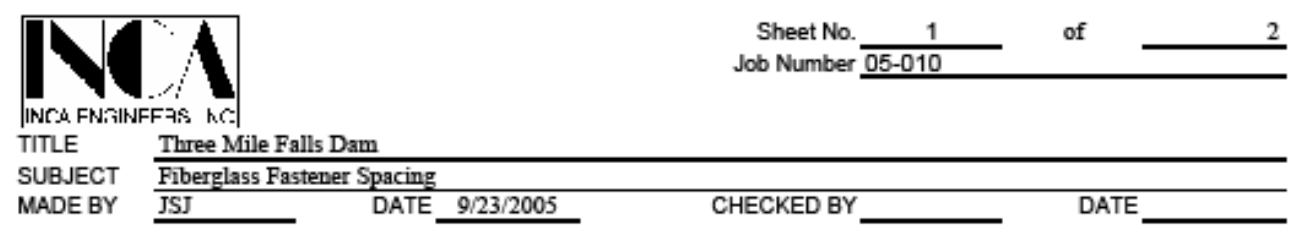

For the design loading on these fasteners, assume that the water level is to the top of the cap beam on one side, and that the pool is dry on the other.

Also assume that the blockage at the weir slot only spans the antenna opening and none of the load is carried by the adjoining concrete precast weir segments (this is very unlikely).

The shearing force on the fasteners is greatest near the bottom of the weir slot due to increasing head pressure with depth.

The lateral force resulting from a head differential acting on the weir is as follows:

Depth of water upstream

Depth of water downstream

Width of slot opening (concr. to concr.)

$0 \mathrm{ft}$

The portion of the antenna that extends into the recess in the floor of the ladder will be supported against lateral forces by the HDPE bearings. This will absorb the lateral force on the antenna. Assume that the fiberglass guides are required to resist the lateral force beginning 1.5 feet above the floor of the ladder.

Assume $1 / 4^{\prime \prime}-20$ fasteners used.

Number of feet above the floor of the ladder:

Vertical spacing between fasteners

Number of fasteners at each vertical interval

Loading per fastener

$$
\begin{gathered}
1.5 \mathrm{ft} \\
12 \mathrm{in} \\
4 \\
312.5 \mathrm{lb}
\end{gathered}
$$

$$
\begin{array}{r}
4 \mathrm{ft} \\
18 \mathrm{in} \\
4 \\
312.5 \mathrm{lb}
\end{array}
$$

OK - allowable shear $=325.9 \mathrm{lbs}$

Number of fasteners at each vertical interval Loading per fastener

Number of feet above the floor of the ladder: Vertical spacing between fasteners Number of fasteners at each vertical interval Loading per fastener
OK - allowable shear $=325.9 \mathrm{lbs}$ 


\begin{tabular}{|c|c|c|c|c|c|c|c|c|c|c|}
\hline Material Name & \begin{tabular}{|c|} 
Young's \\
Modulus, \\
E \\
(Msi)
\end{tabular} & \begin{tabular}{|c|} 
Shear \\
Modulus, \\
G \\
(Msi)
\end{tabular} & $\begin{array}{l}\text { Poisson } \\
\text { Ratio, v }\end{array}$ & \begin{tabular}{|c|} 
Density, \\
$\left(\mathrm{lb} / \mathrm{in}^{3}\right)$
\end{tabular} & \begin{tabular}{|c}
$\begin{array}{c}\text { Tensile } \\
\text { Strength }\end{array}$ \\
Ultimate \\
(Ksi)
\end{tabular} & $\begin{array}{c}\text { Tensile } \\
\text { Strength } \\
\text { Yield } \\
\text { (Ksi) }\end{array}$ & $\begin{array}{c}\text { Shear } \\
\text { Strength } \\
\text { Ultimate } \\
\text { (Ksi) }\end{array}$ & $\begin{array}{c}\text { Shear } \\
\text { Strength } \\
\text { Yield } \\
\text { (Ksi) }\end{array}$ & \begin{tabular}{|c|} 
CTE \\
$\left(10^{-8}\right.$ in/in \\
$\left.{ }^{\circ} \mathrm{F}\right)$
\end{tabular} & Source \\
\hline $\begin{array}{l}\text { Steel, Stainless, 18-8 } \\
\text { (AISI 301), Annealed }\end{array}$ & 29 & 11.2 & 0.27 & 0.286 & 75 & 30 & 27 & 15.6 & 8.6 & $\begin{array}{l}\text { Military Handbook 5E } \\
\text { (1987). S-Basis (minimum } \\
\text { aerospace property levels) }\end{array}$ \\
\hline $\begin{array}{l}\text { Steel, Stainless, 18-8 } \\
\text { (AISI 301), 1/2 Hard }\end{array}$ & 26 & 10.5 & 0.27 & 0.286 & 151 & 105 & 72 & 41 & 8.6 & $\begin{array}{l}\text { (1987), B-Basis ( } 90 \% \text { of } \\
\text { properties exceed value, } \\
\text { 95\% confidence) }\end{array}$ \\
\hline $\begin{array}{l}\text { Steel, Stainless, 18-8 } \\
\text { (AISI 301), Full Hard }\end{array}$ & 28 & 10.5 & 0.27 & 0.286 & 185 & 142 & 98 & 56.6 & 8.6 & $\begin{array}{l}\text { (1987), B-Basis ( } 90 \% \text { of } \\
\text { properties exceed value, } \\
85 \% \text { confidence) }\end{array}$ \\
\hline
\end{tabular}




\section{Appendix B-4 \\ Three Mile Falls Dam Adult Fish Ladder \\ Site Visit Photos \\ 04 March 2005}

The following photos were taken during an on-site visit to Three Mile Falls Dam in March of 2005

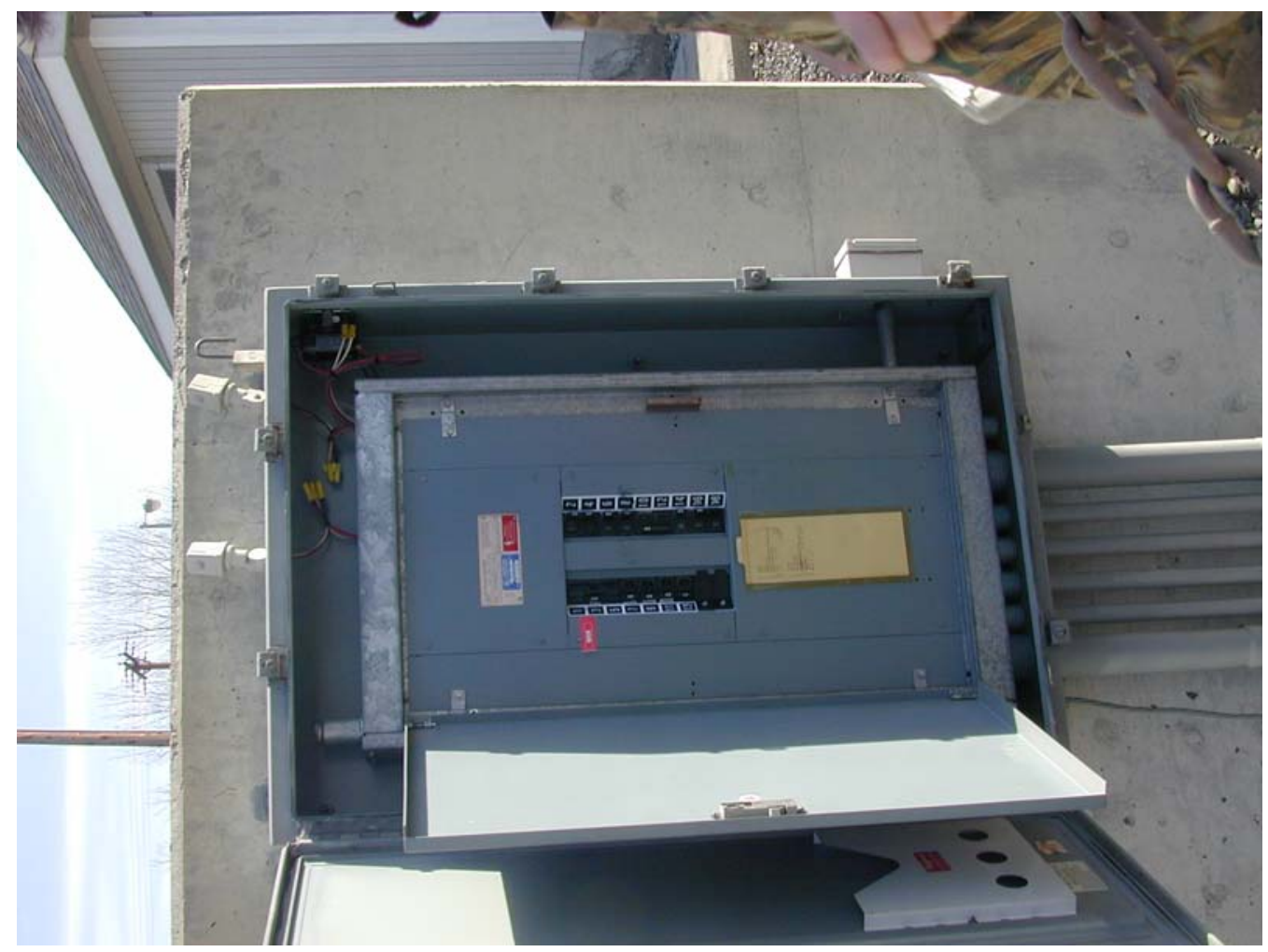

Photo 1. (DSCN1339) LP Panelboard at east bank of Three Mile Falls Dam (TMFD). 


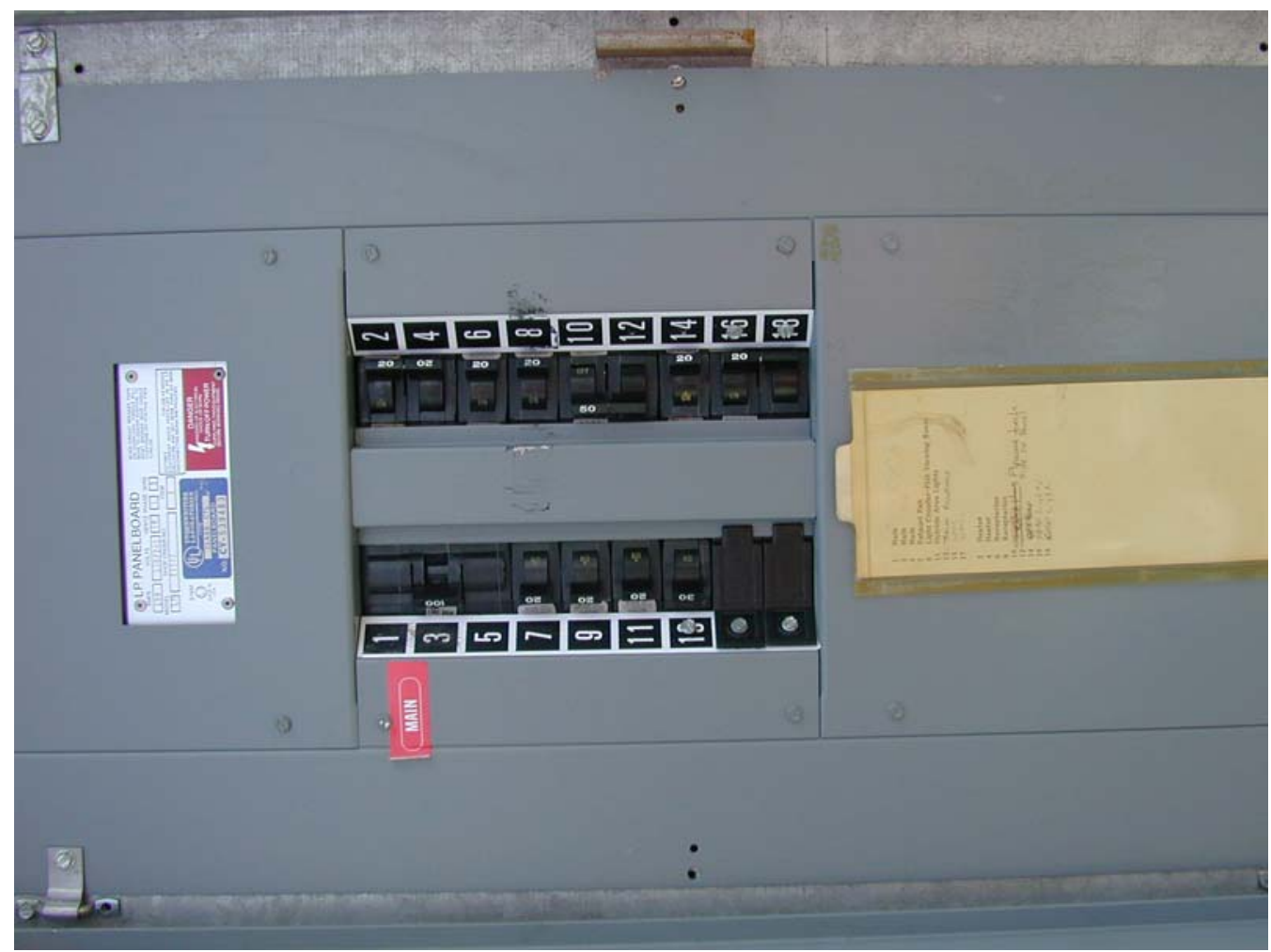

Photo 2. (DSCN1340) Close-up view of LP Panelboard at east bank of TMFD.

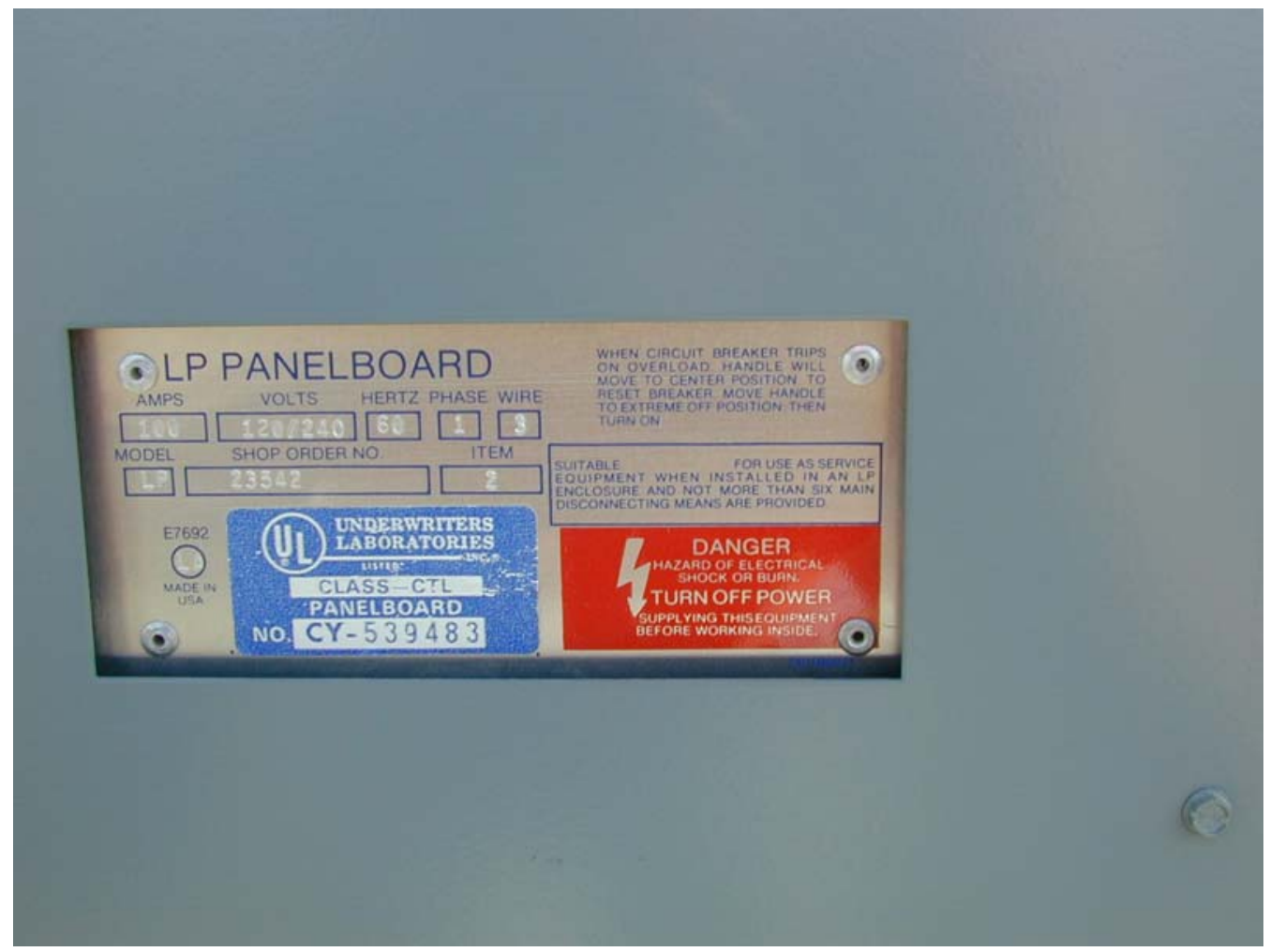

Photo 3. (DSCN1341) Panelboard label at east bank adult fish ladder at TMFD. 


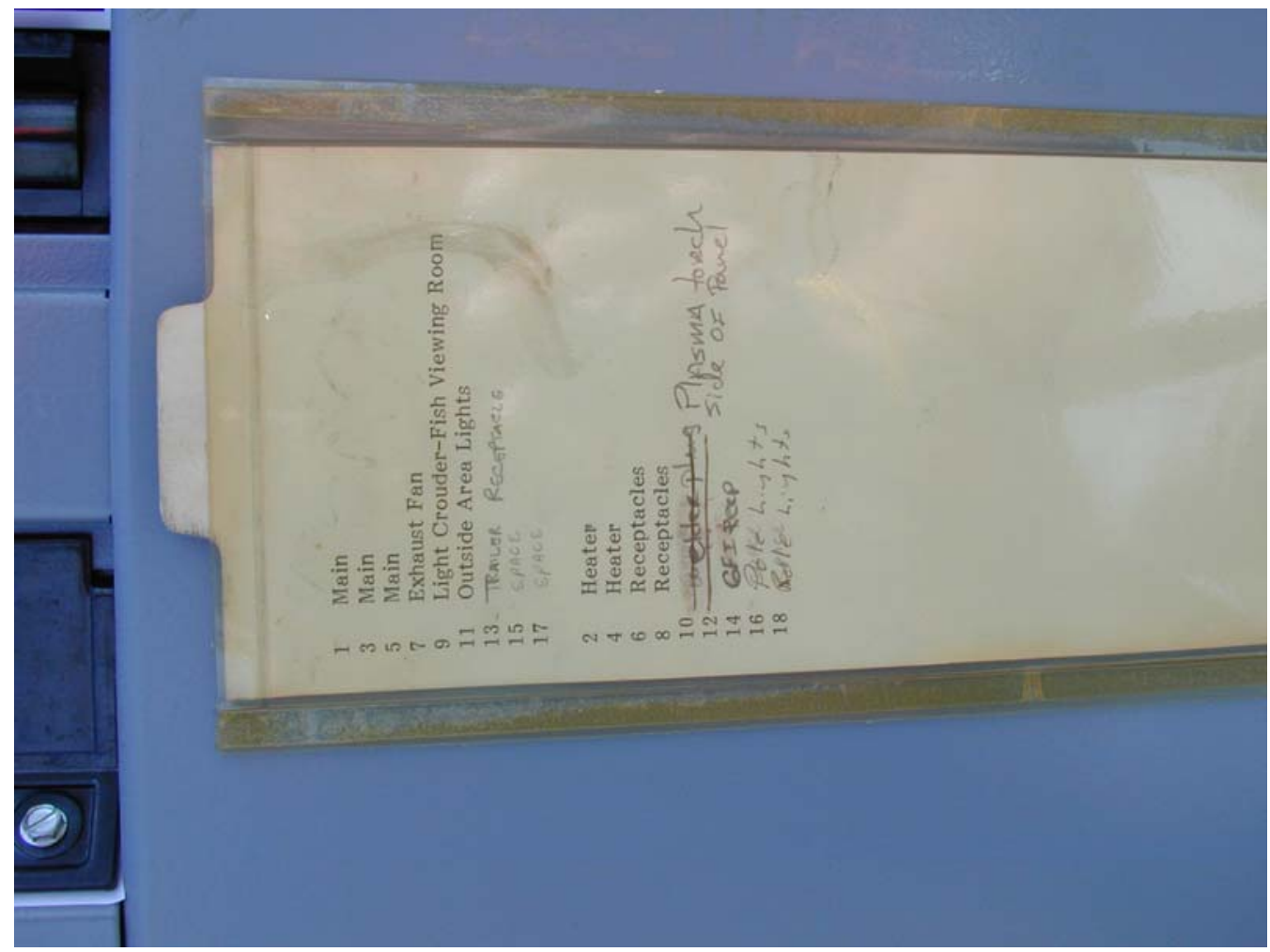

Photo 4. (DSCN 1342) Panelboard key at east bank adult fish ladder at TMFD.

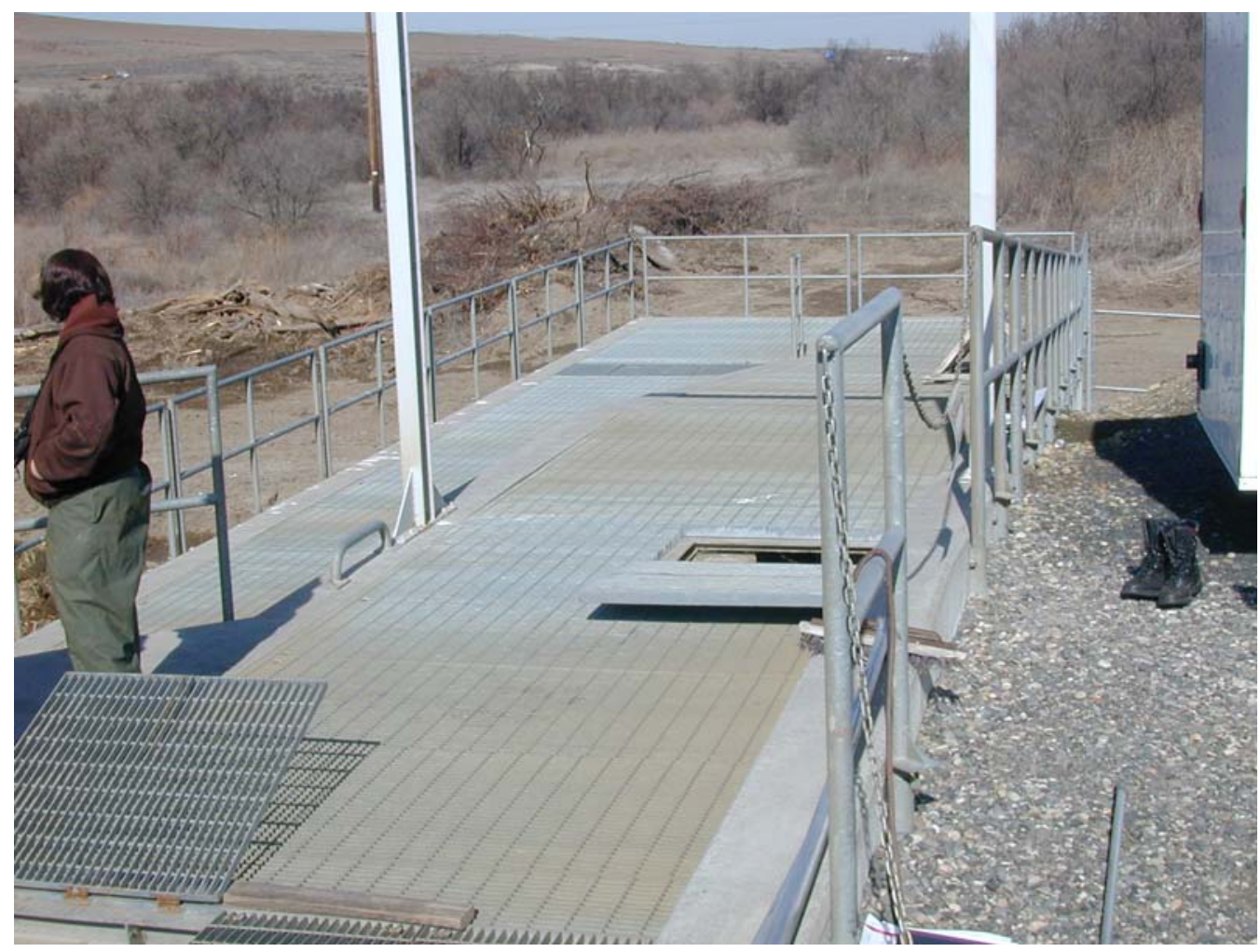

Photo 5. (DSCN 1343) Northfacing view of walkway along the east bank adult fish ladder at TMFD. Taken directly above the adult counting window. 


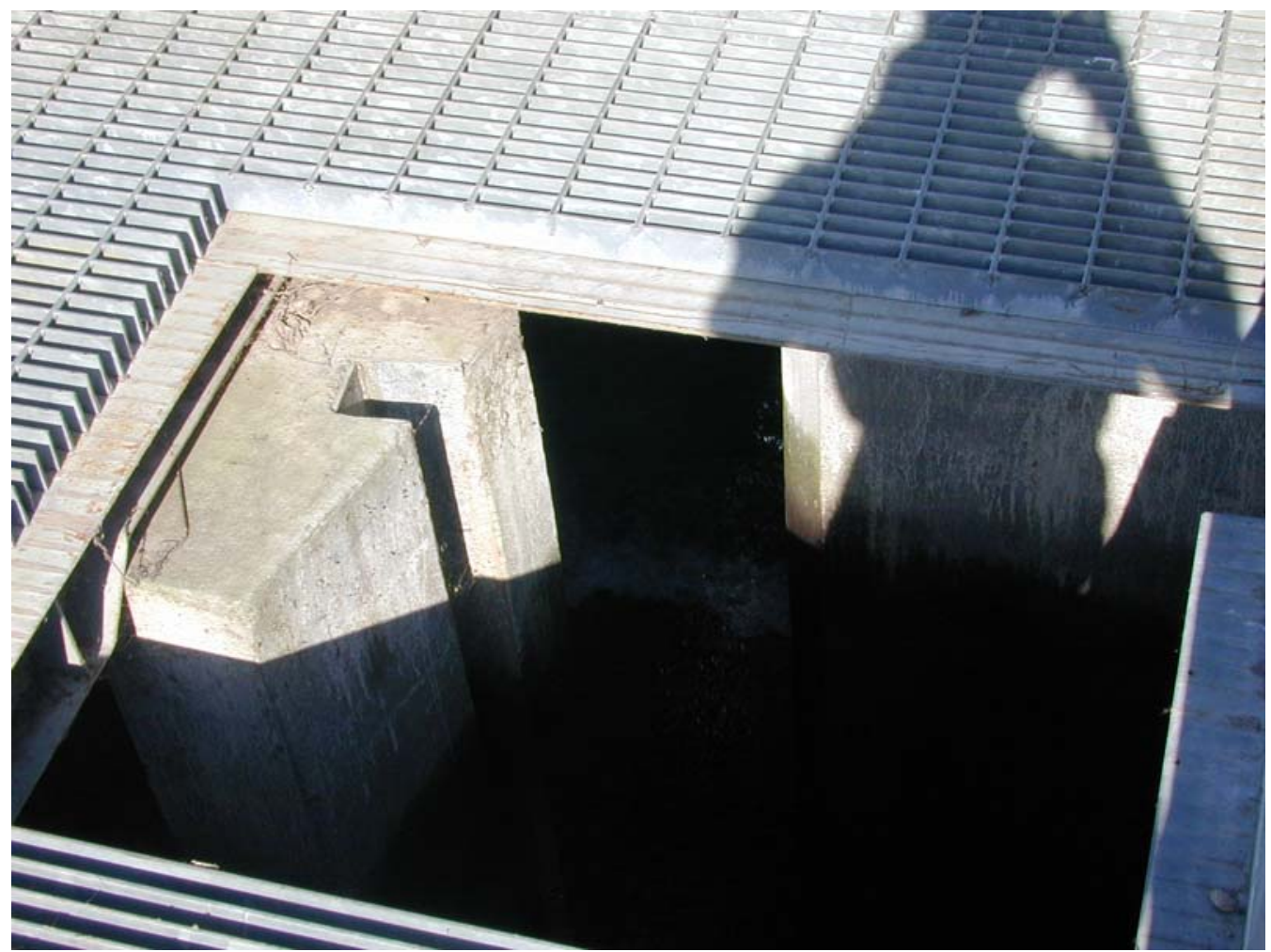

Photo 6. (DSCN 1344) View of vertical slots within the adult fish ladder at TMFD.

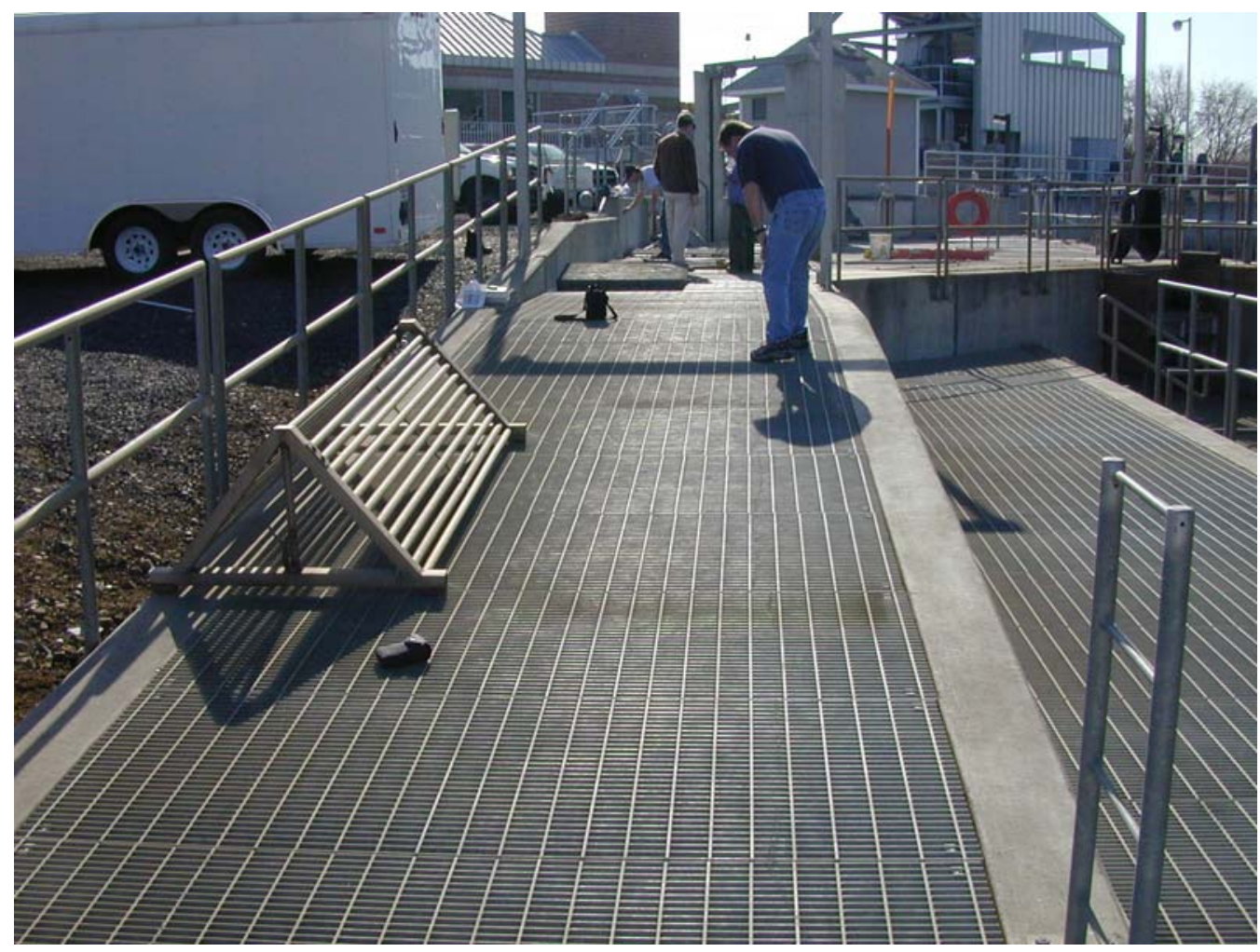

Photo 7. (DSCN 1345) Southfacing view of walkway on east bank adult fish ladder of TMFD. 


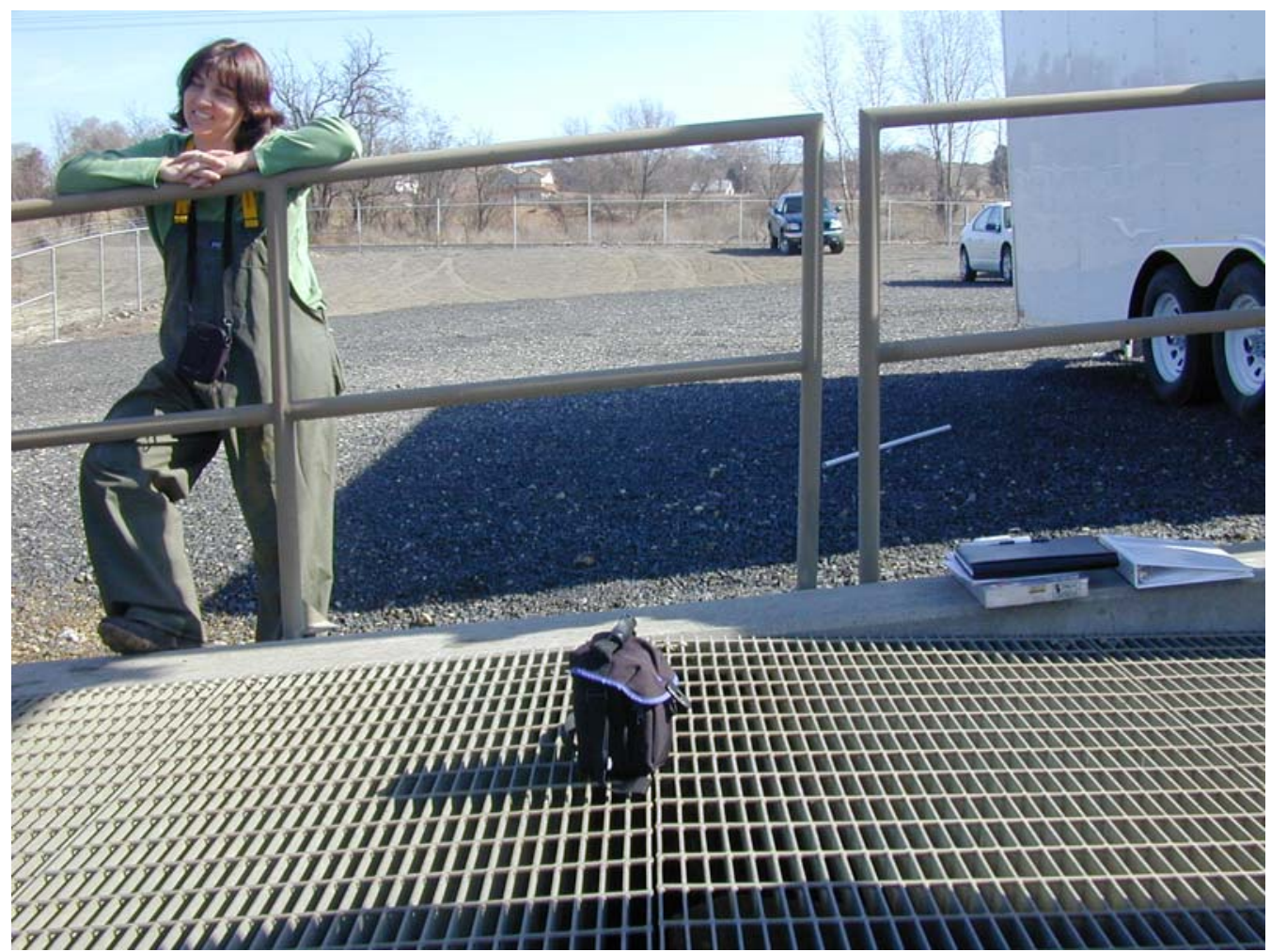

Photo 8. (DSCN 1346) Proposed antenna location \#1 at second weir downstream of the counting window, TMFD.

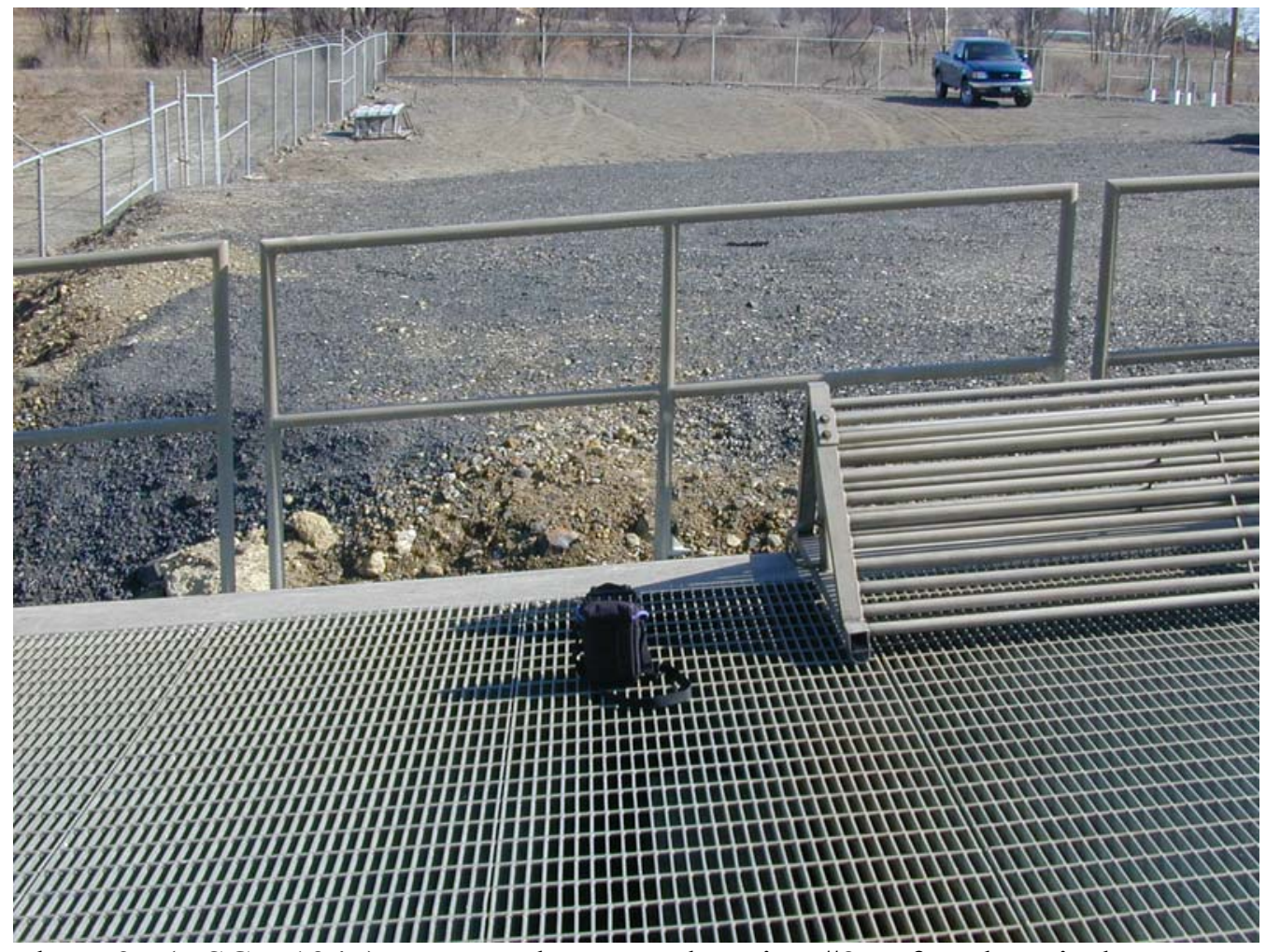

Photo 9. (DSCN 1347) Proposed antenna location \#2 at fourth weir downstream of the counting window, TMFD. 


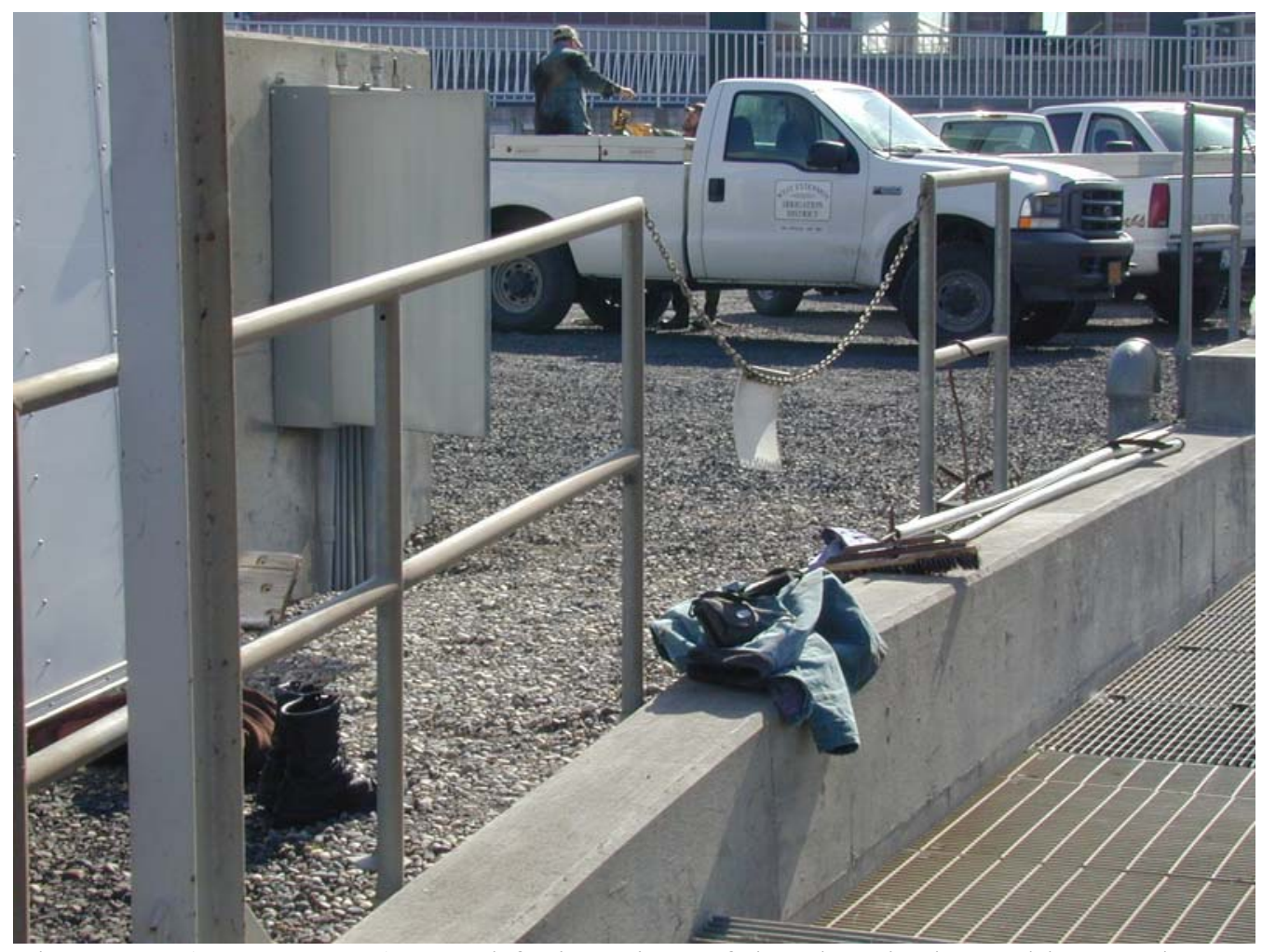

Photo 10. (DSCN 1348) Southfacing view of the electrical panel box and walkway along east bank adult fish ladder, TMFD.

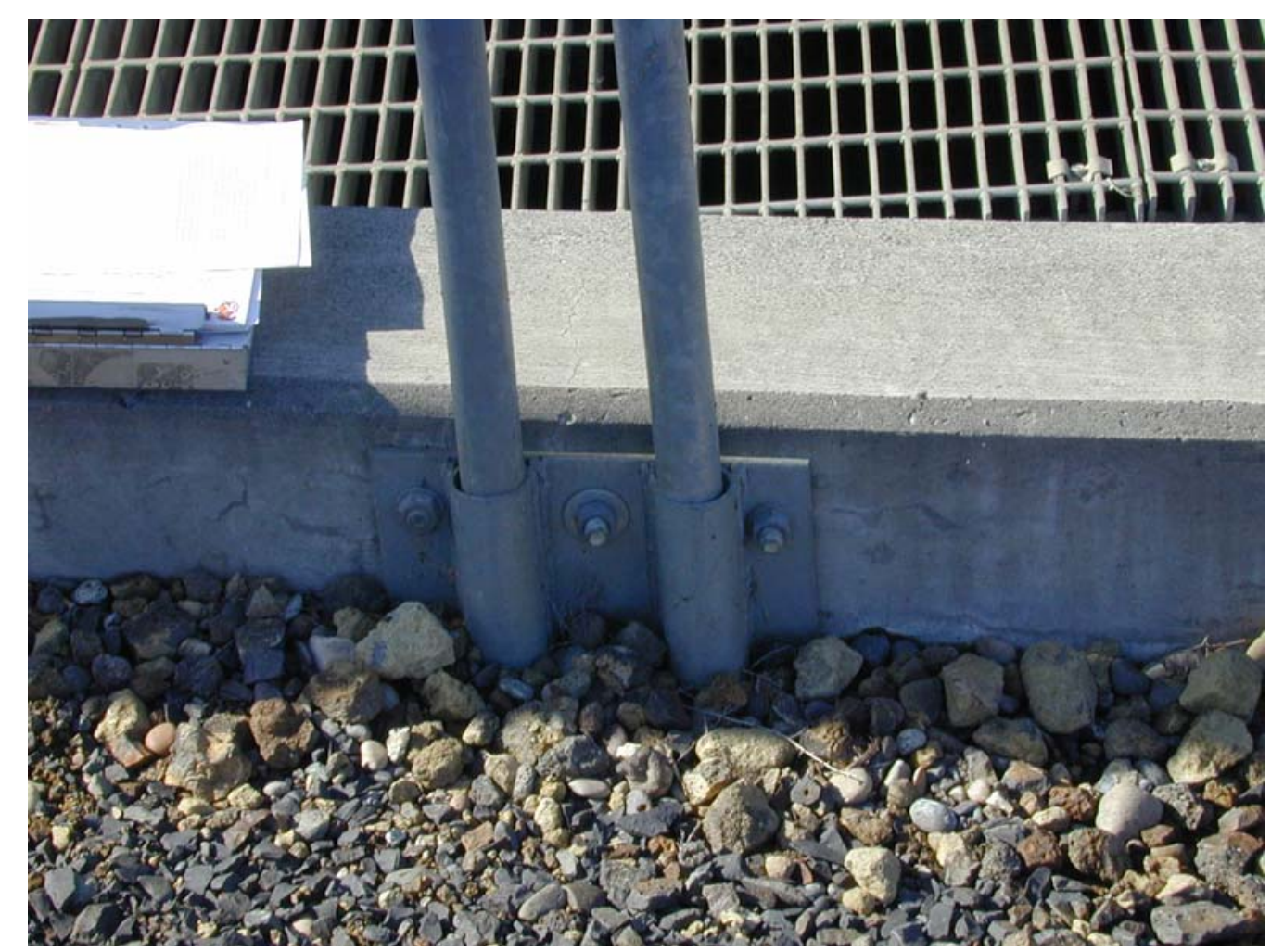

Photo 11. (DSCN 1349) View of handrail attachments, TMFD. 


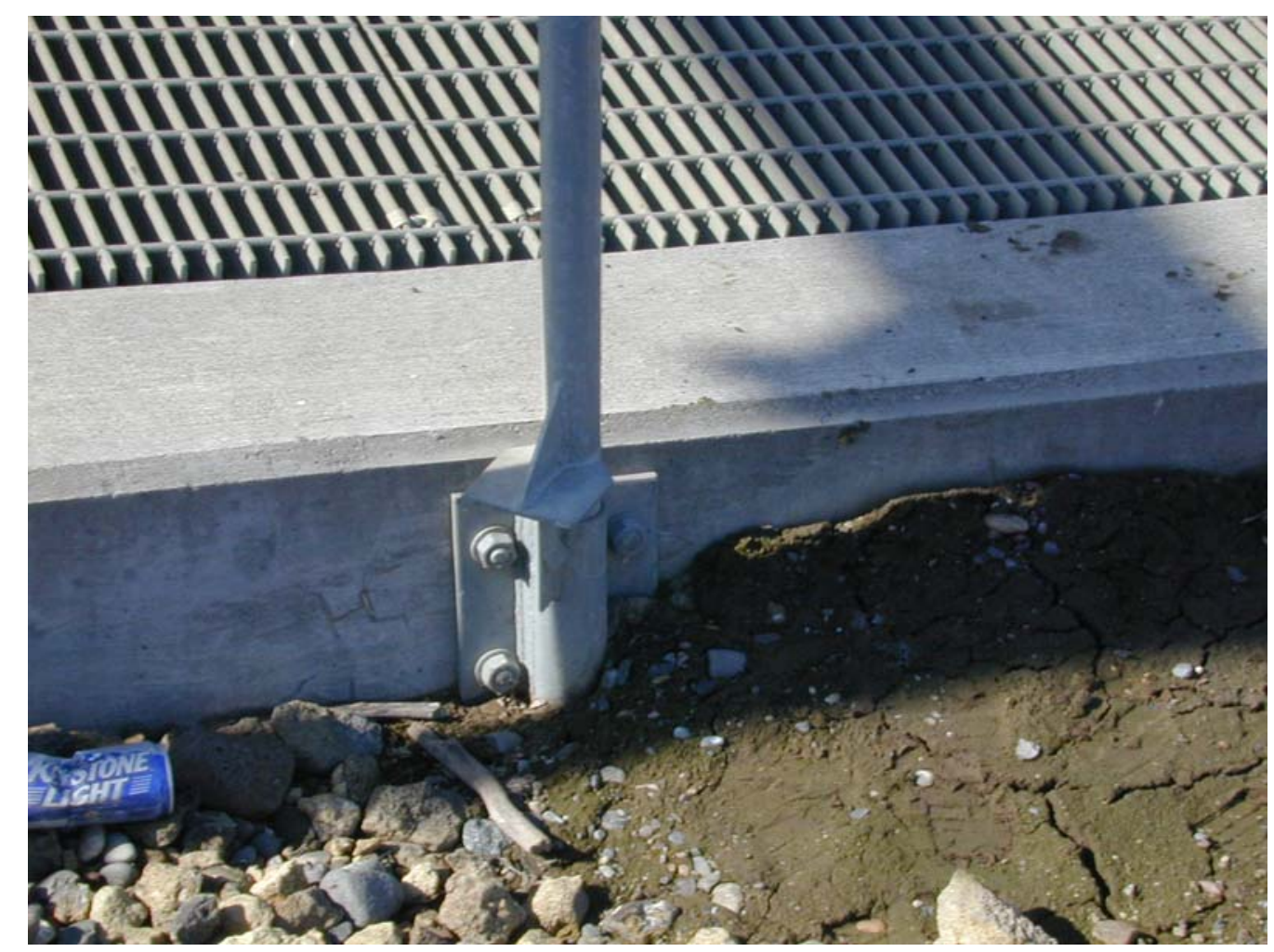

Photo 12. (DSCN 1350) View of handrail attachment along ladder wall.

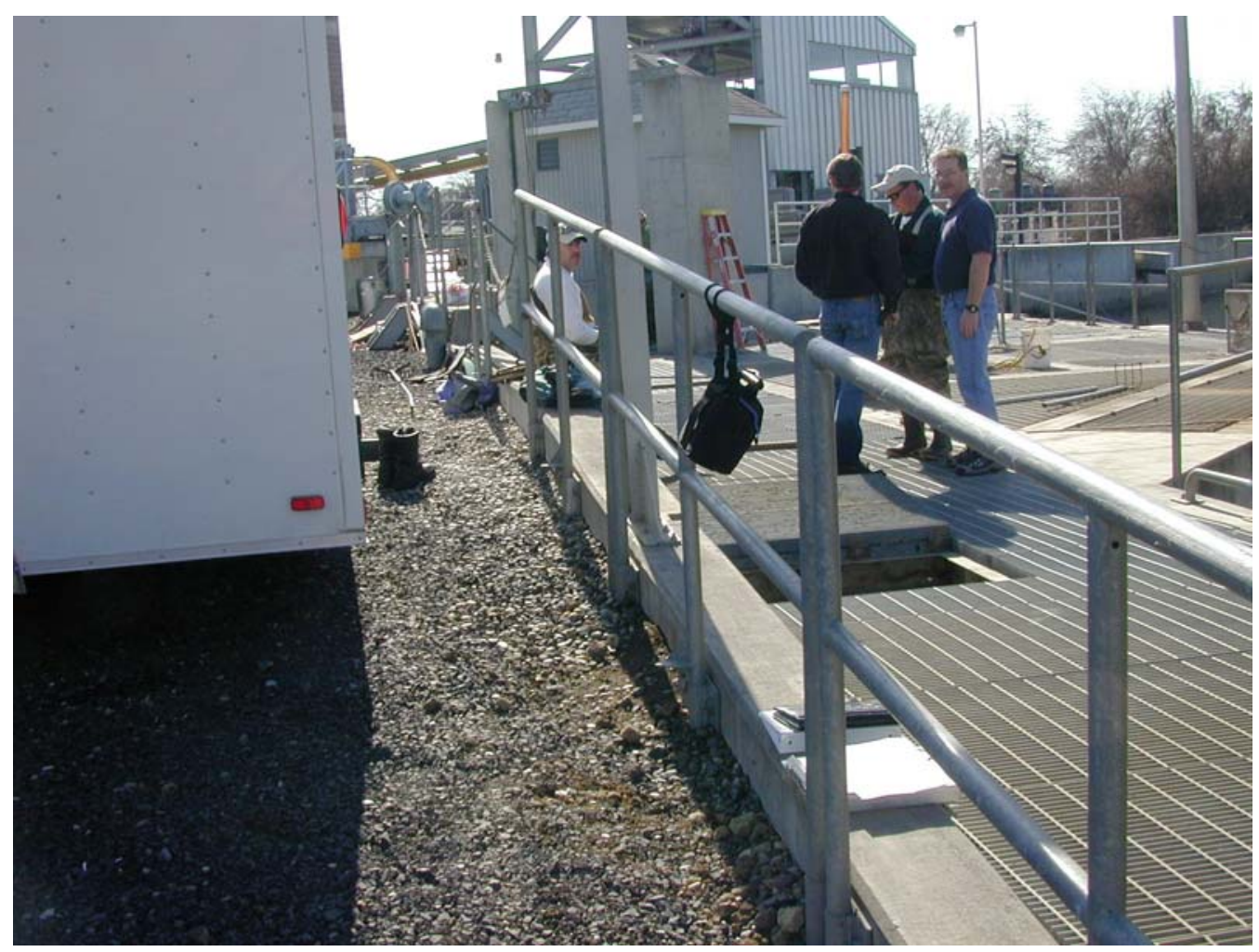

Photo 13. (DSCN 1351) South facing view of walkway and corner of electronics room trailer at east bank adult fish ladder of TMFD. 